A Professional Project Thesis

Presented to

The Faculty of California Polytechnic University,

San Luis Obispo

In Partial Fulfillment

Of the Requirements for the Degree

Master of City and Regional Planning and Master of Science in Engineering with specialization in Transportation Planning

By

Anthony Adams

June 2011 
(C) 2011

Anthony Shae Adams

ALL RIGHTS RESERVED 
COMMITTEE MEMBERSHIP

TITLE: THE CITY OF LAKE CHARLES BICYCLE AND PEDESTRIAN MASTER PLAN

AUTHOR:

DATE SUBMITTED:

COMMITTEE CHAIR:

COMMITTEE MEMBER:

COMMITTEE MEMBER:

\author{
Anthony Shae Adams
}

June 2011

Michael Boswell, Associate Professor \& Graduate Coordinator

Adrienne Greve, Assistant Professor

Russell Adams, Director of Planning at City of Lake Charles 


\begin{abstract}
THE CITY OF LAKE CHARLES BICYCLE AND PEDESTRIAN MASTER PLAN Anthony Shae Adams
\end{abstract}

This thesis was done in the professional project format. It was completed as a deliverable to the City of Lake Charles, Louisiana. It was developed in accordance with the State of Louisiana Bicycle and Pedestrian Master Plan.

A bicycle and pedestrian master plan is a document meant to serve as a guide to staff and decision-makers on how to best develop future bicycle and pedestrian improvements. It is a comprehensive document that identifies and prioritizes new projects for sidewalks, bicycle facilities, and off-street paths. It accomplishes this by following these steps:

1. Identify existing bicycle and pedestrian infrastructure.

2. Provide a "on the ground" survey of conditions of existing infrastructure.

3. Conduct public input sessions to gather information regarding necessary projects.

4. Apply four criteria (Attractors, Generators, Connectivity, and Affordability) to rank the priority of each project.

5. Identify likely funding sources for each project.

6. Suggest steps for plan implementation and next steps.

7. Present findings to public and elected officials.

Following these steps, a complete bicycle and pedestrian master plan was developed. A total of 149 sidewalk projects, 40 bicycle network projects, and five off-street multi-use paths were identified and prioritized. The identification of these projects will serve to assist in their inclusion to the City’s and regional planning bodies transportation improvement plan (TIP). 


\section{The City of Lake Charles}

Bicycle and Pedestrian Master Plan Draft

$5 / 25 / 2011$

Prepared by Anthony Adams
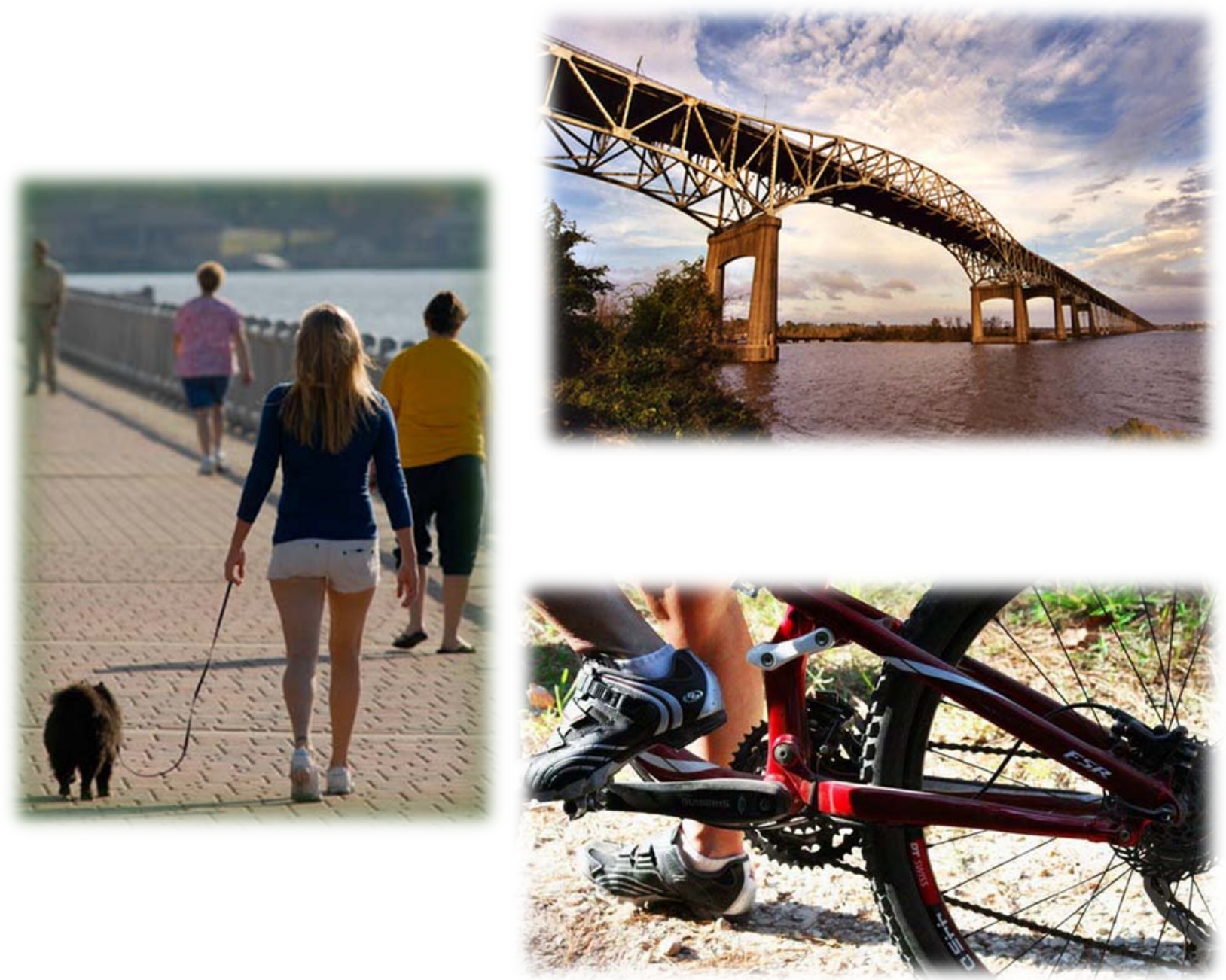


\section{Acknowledgements}

Randy Roach - Mayor of the City of Lake Charles

Russ Adams - City of LC Dept. of Planning

Shelly Appleby - City of LC Dept. of Downtown Development

Jasmin Kurt - City of LC Dept. of Planning

Lori Morinovich - City of LC Dept. of Planning

Bill Browne - City of LC Dept. of Engineering

Shelly Fontentot- City of LC Dept. of Engineering

Michael Boswell - California Polytechnic University Professor

Adrienne Greve - California Polytechnic University Professor

Dimitri Antoniou - California Polytechnic University Alum

Kathleen Ryan - Support Services

Rosemary Hohn - Support Services

Carol Campbell - Support Services 


\section{Table of Contents}

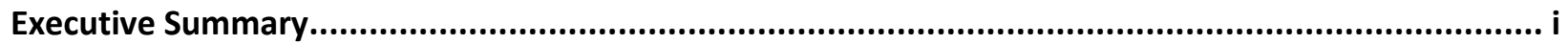

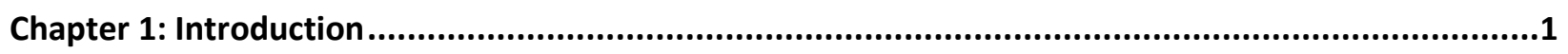

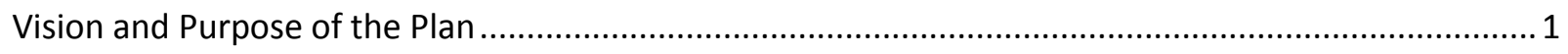

Why Develop a Bicycle and Pedestrian Master Plan? .................................................................... 2

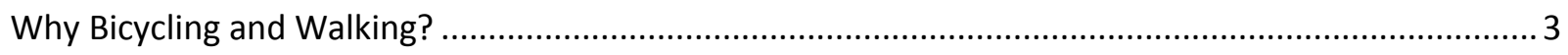

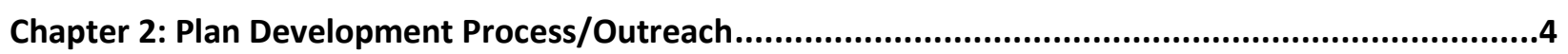

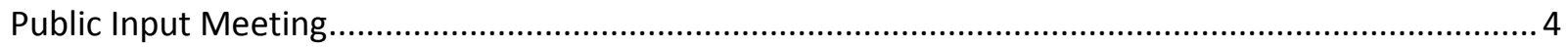

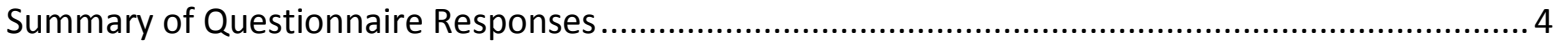

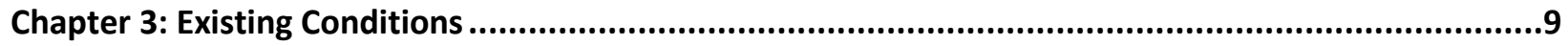

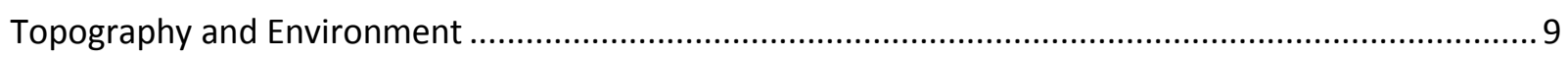

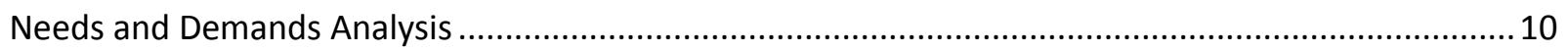

Constraints and Opportunities in Calcasieu Parish ......................................................................... 10

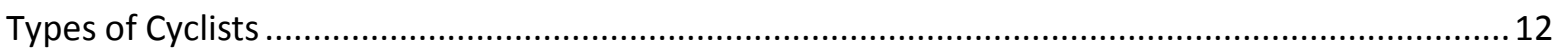

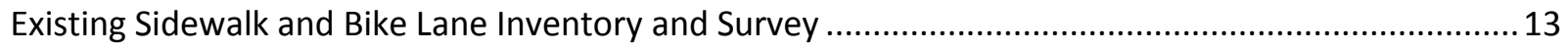

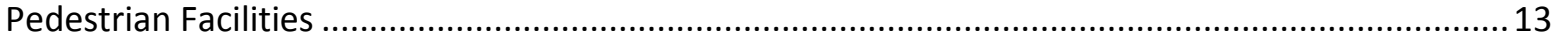

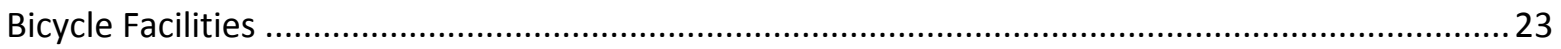

Current or Ongoing Bicycle or Pedestrian Support Expansion Projects ........................................26

Chapter 4: Goals and Policy Recommendations............................................................................27

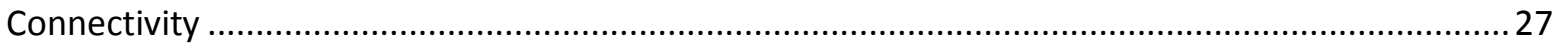

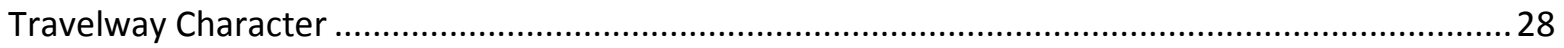

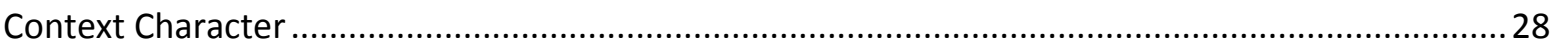

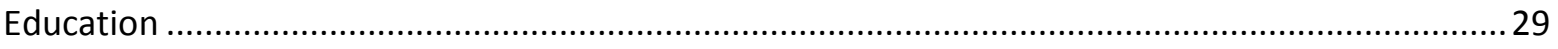

Safety

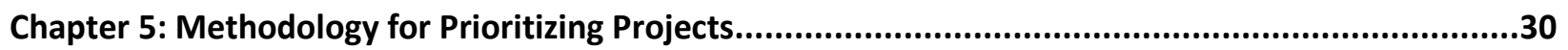

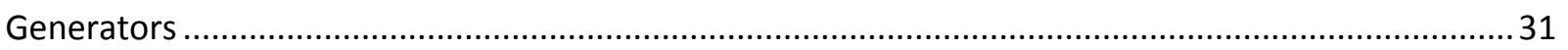

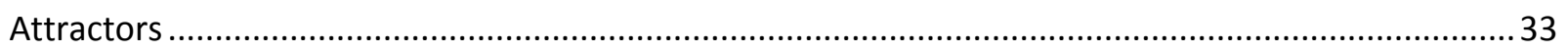

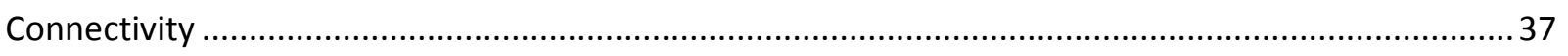

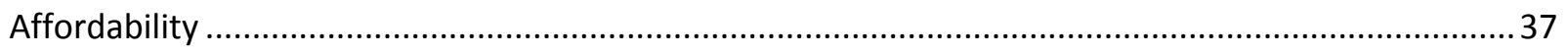

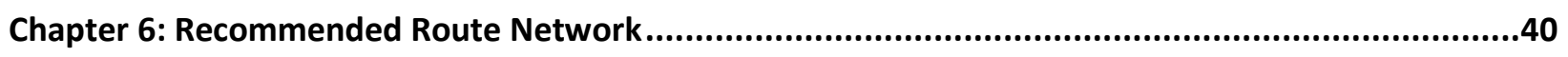

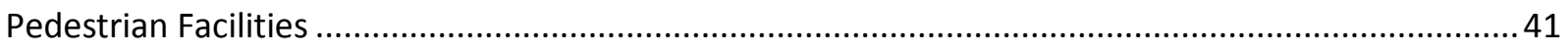

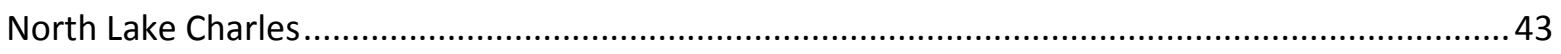

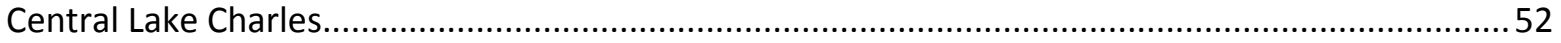


The City of Lake Charles

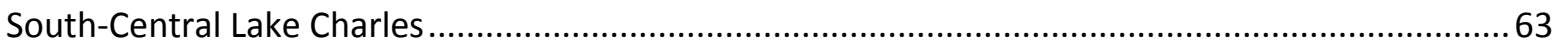

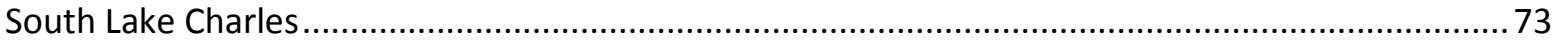

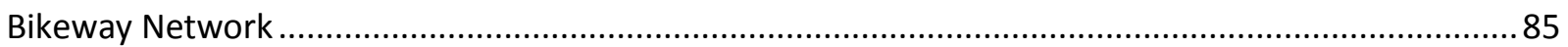

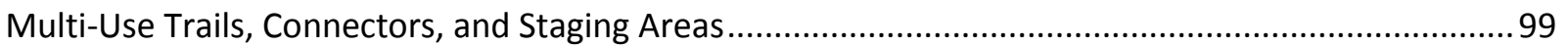

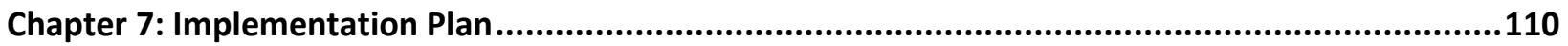

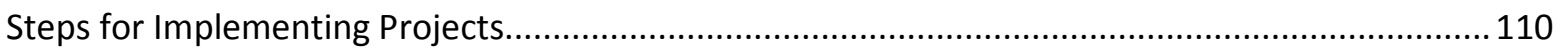

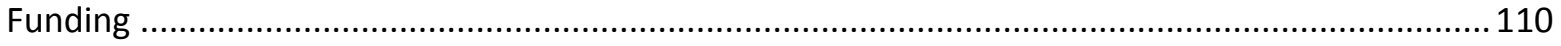

Chapter 8: Recommendations for Updates............................................................................112

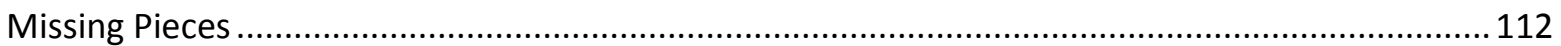

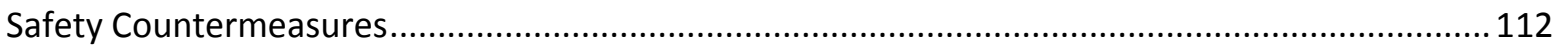

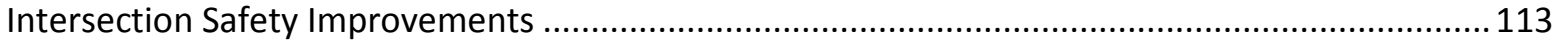

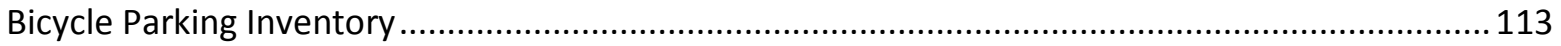

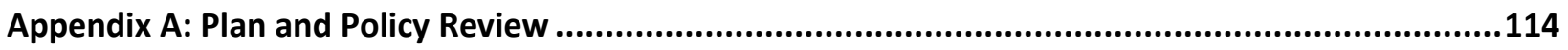

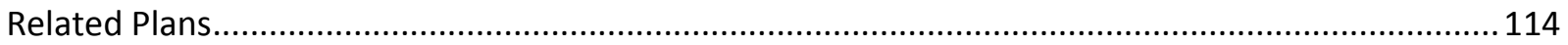

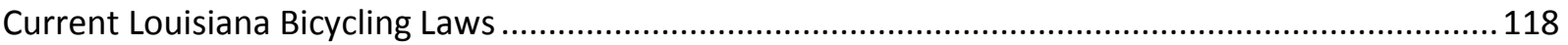

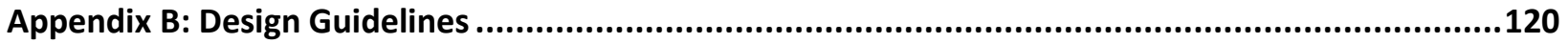

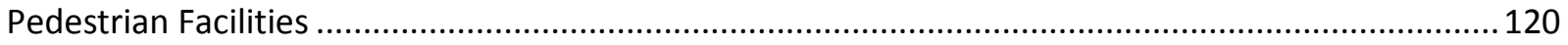

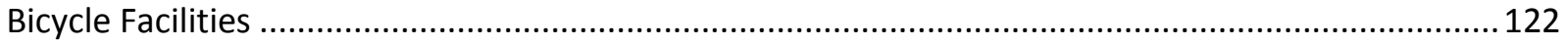

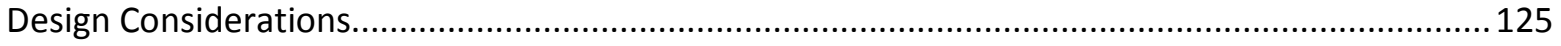

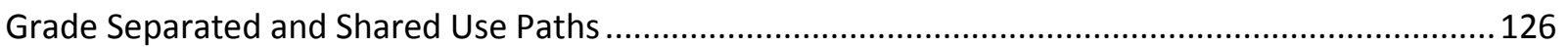

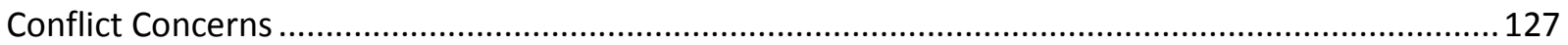

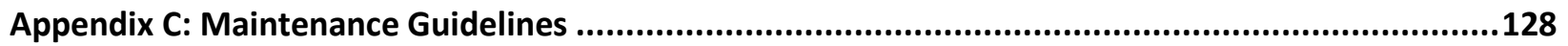

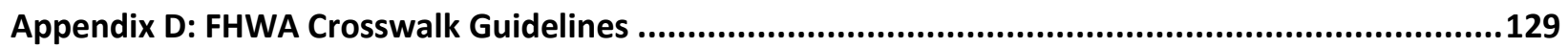

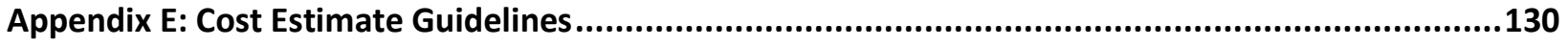

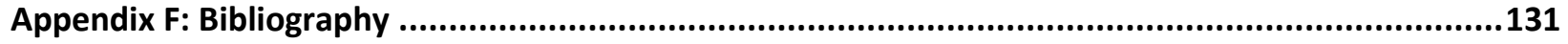

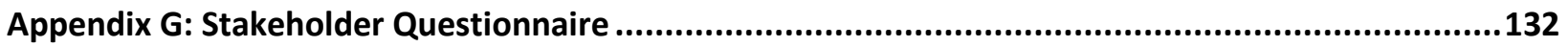




\section{Table of Figures}

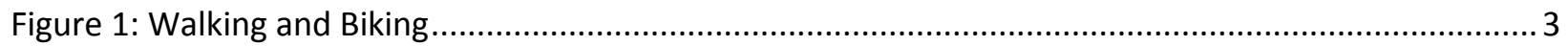

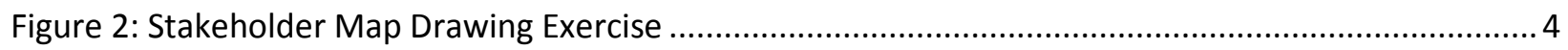

Figure 3: Calcasieu Parish beams with waterways and wildlife......................................................... 9

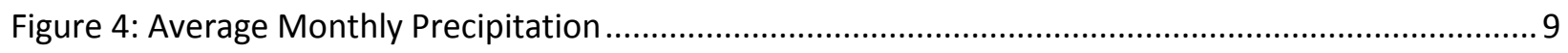

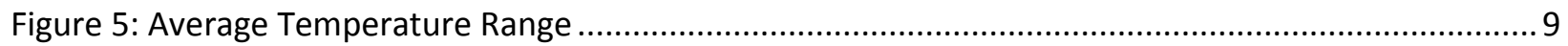

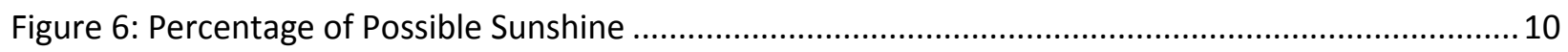

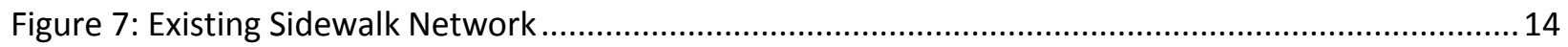

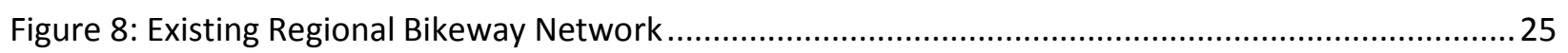

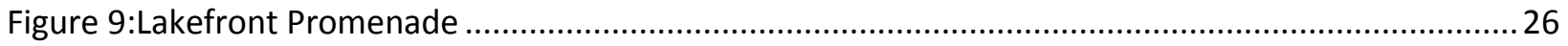

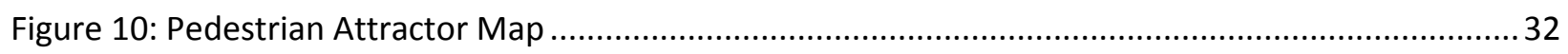

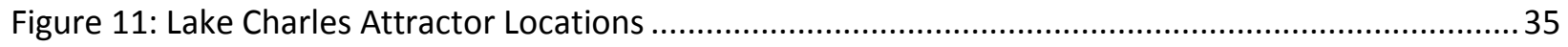

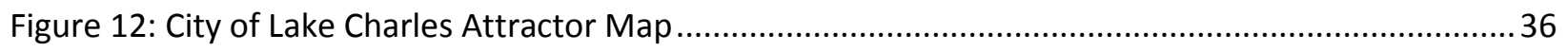

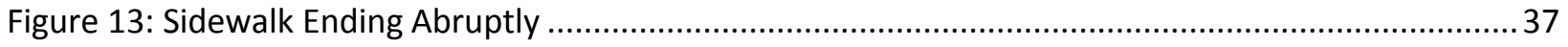

Figure 14: City-wide Proposed Sidewalk Network Improvements ....................................................... 42

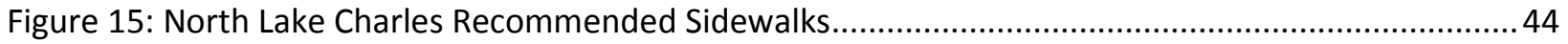

Figure 16: Central Lake Charles Recommended Sidewalks ....................................................................54

Figure 17: South-Central Lake Charles Recommended Sidewalks........................................................65

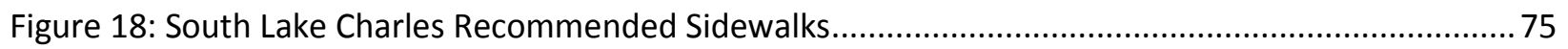

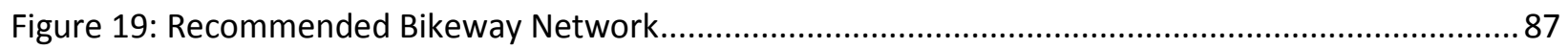

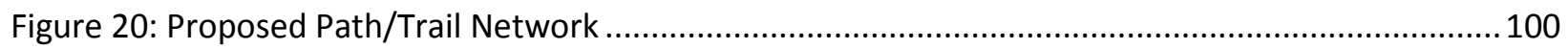

Figure 21: Perkins Ferry Trail Aerial Photograph .............................................................................. 101

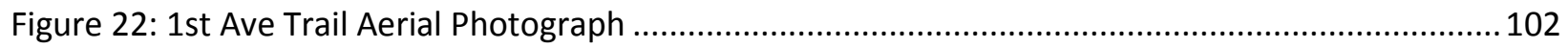

Figure 23: Lakeshore Canal Trail Aerial Photograph........................................................................ 103

Figure 24: Railroad Connector Trail Aerial Photograph ...................................................................... 104

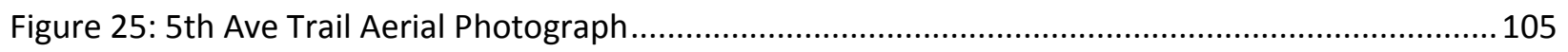

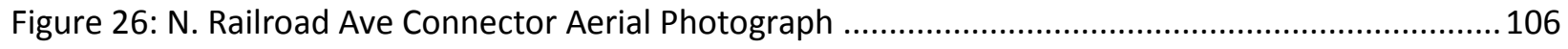

Figure 27: 13th Ave Connector Aerial Photograph ............................................................................ 106

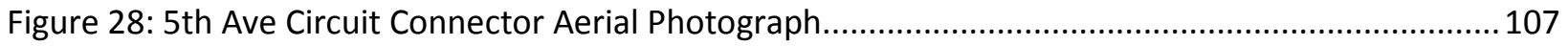

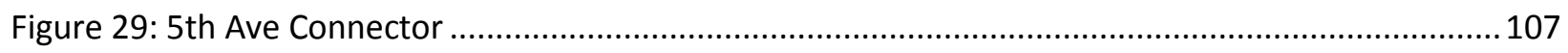

Figure 30: Parkway St Connector Aerial Photograph.......................................................................... 108

Figure 31: Proposed Complete Bicycle and Pedestrian Route Network.............................................. 109

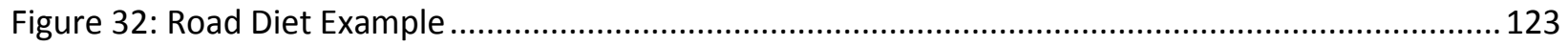

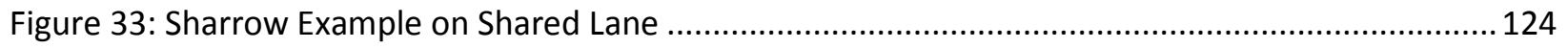

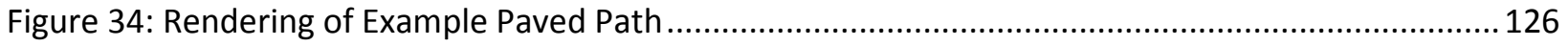

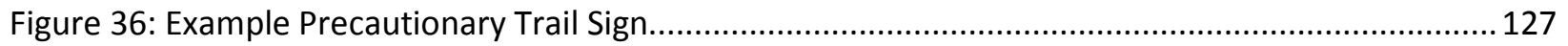

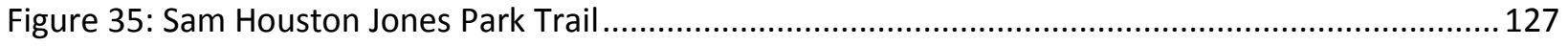

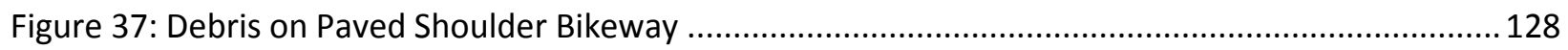




\section{Table of Tables}

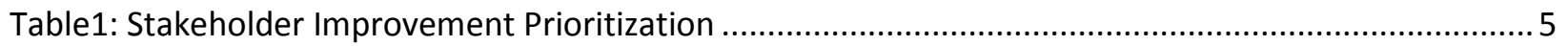

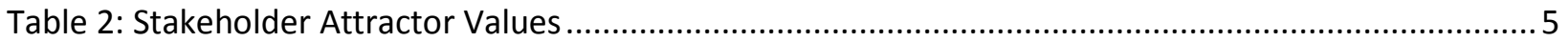

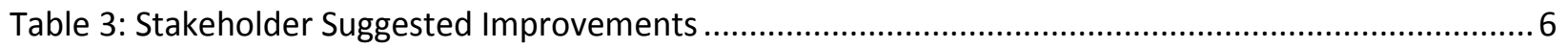

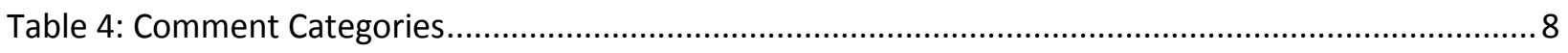

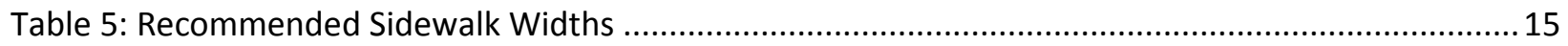

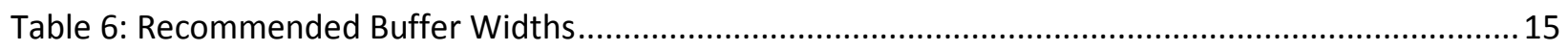

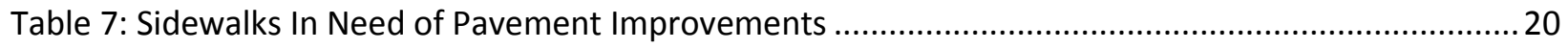

Table 8: Sidewalk in Need of Landscape Maintenance........................................................................ 21

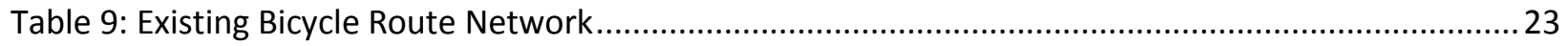

Table 10: Existing Regional Bicycle Network with Shoulder Available for Bicycles ..................................24

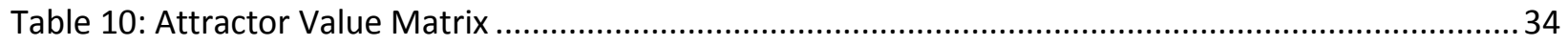

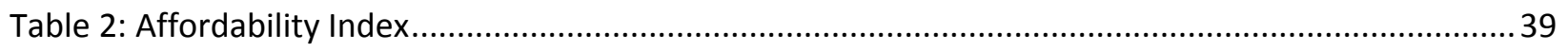

Table 3: North Lake Charles Recommended Sidewalks ...................................................................... 43

Table 4: Central Lake Charles Recommended Sidewalks.....................................................................53

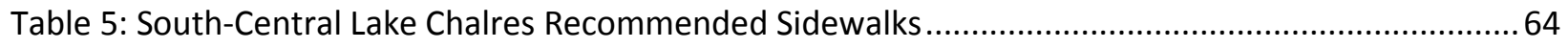

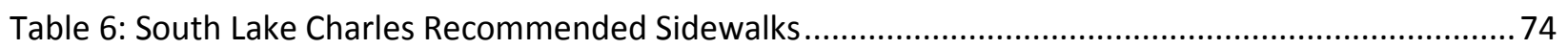

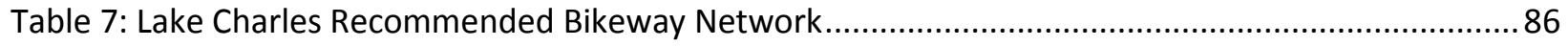

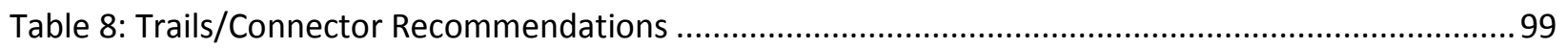

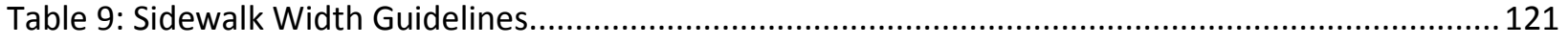

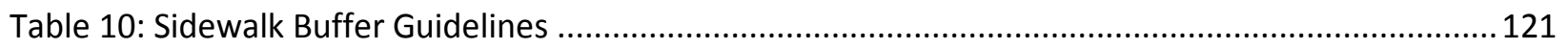

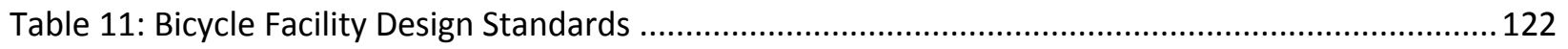

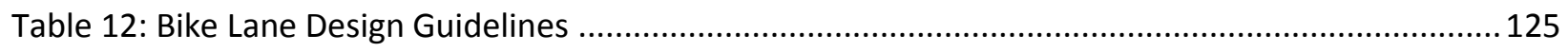

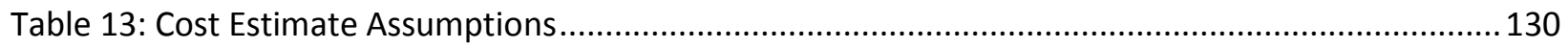




\section{Executive Summary}

This plan is being developed in accordance with the Louisiana Statewide Pedestrian and Bicycle Master Plan. It is meant to serve as a guide for local decision-makers and the public in how best to plan for alternative modes of transportation in future development. It accomplishes this by conducting a comprehensive inventory and analysis of existing bicycle and pedestrian facilities in the City of Lake Charles; complete with a prioritized list of improvements. Suggested improvements will incorporate sidewalks, bike routes, bike lanes, and multi-use recreational trails into a comprehensive network with the goal of increasing access and mobility for non-motorized modes of travel. The Plan also recommends a variety of policies to allow for safe, efficient, and convenient pedestrian and bicycle travel in and between the communities of the City of Lake Charles.

\section{Vision of the Plan (Chapter 1)}

"To promote the City of Lake Charles as a bicycle and pedestrian-friendly environment by providing a variety of transportation choices that promote accessible alternatives to the automobile; where public spaces, including streets and off-street paths, will offer a level of convenience, safety and attractiveness that will encourage and reward the choice to bike or walk."

\section{Public Input (Chapter 2)}

Stakeholders such as governmental agencies, private individuals, and bicycling and walking organizations were contacted and invited to attend a public input session. A public notice was printed in the newspaper and local news broadcast for anyone who might have an interest in improving pedestrian and bicycle travel within the Lake Charles metro area to attend the meeting. The purpose of the meeting was to receive information from the public regarding which areas were in most need of bicycle and pedestrian improvements. A questionnaire was

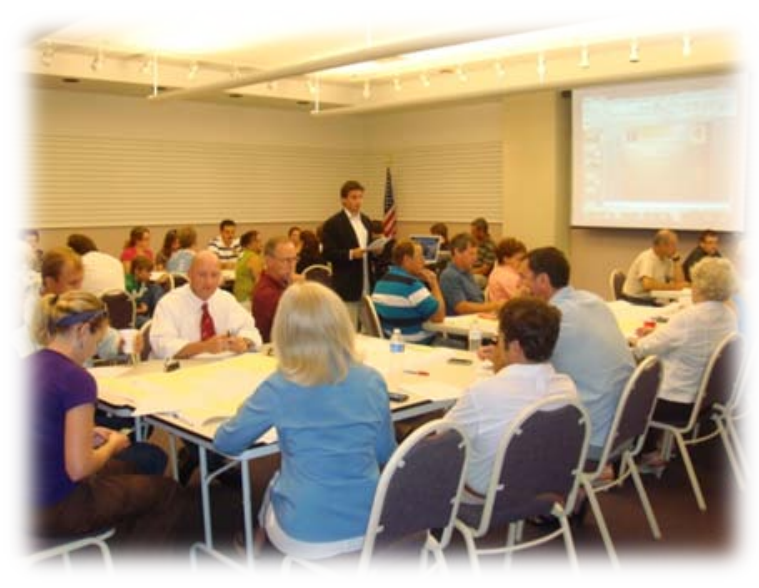
developed to solicit specific input on key issues and concerns regarding the pedestrian and bicycle facilities system, and to generate input regarding the most important issues to be addressed and potential priority order for types of projects and system improvement.

Respondents were encouraged to share stories in which they or someone they know has experienced traveling throughout the City without an automobile. Many people shared their experiences and gave detailed opinions about what could be improved. The following quote is a good representation of the general sentiment of respondents when it came to Lake Charles' lack of pedestrian and bicycle support. 
"I think that the roads that have the heaviest motor vehicle traffic should have ped \& bicycle lanes. These are the roads people need to use to get to jobs, schools, shopping, etc. Roads that would be great are Ryan, Common, McNeese, Prienlake, and Sale. McNeese students want to ride to class also have a lot of trouble. I also think there needs to be education for motor vehicle drivers. Most drivers do not understand that they must share the road with bicycles."

Stakeholders were then asked to make a list of potential improvements and then draw them out on maps provided at each table. This activity facilitated interaction and new idea creation. Many people took the time to share their comments or concerns with us and also give us their opinion about what was most important to them. These comments or concerns were categorized into a few "themes" and quantified if more than two people mentioned them. Some people mentioned more than one theme in their comments; each comment was counted separately.

\begin{tabular}{|lc|}
\hline \multicolumn{2}{|c|}{ Concerns and Comments Categories } \\
\hline Safety Concerns & Number of Comments \\
\hline Driver Education & 14 \\
\hline Increase Quality of Life & 6 \\
\hline Multi-Use Paths & 5 \\
\hline Bridge over Contraband Bayou & 4 \\
\hline Curbs and Ramps & 3 \\
\hline Clean Shoulders on Roadway & 2 \\
\hline Bicycles Can't Trigger Traffic Signals & 2 \\
\hline \multicolumn{2}{|c|}{ Total Stories or Comments } \\
\hline
\end{tabular}

\section{Existing Conditions (Chapter 3)}

The City of Lake Charles Metro Area has wonderful weather and climate patterns. Southwest Louisiana has a high percentage of sunny days and the temperatures during the Spring and Fall seasons have a very comfortable range. These welcoming conditions make it easy for residents to enjoy the natural setting that Lake Charles region offers.

\section{Constraints and Opportunities in the City of Lake Charles}

\section{Constraints}

$>$ Limited Public Transit System - Existing bus service only runs once per hour and does not cover entire city.

$>$ Waterways, Highways, and Railways - Present barriers that must be crossed with costly bridges.

$>$ Heavy Vehicle Traffic and Rate of Travel Speed - Creates dangerous conditions

$>$ Open Ditches - No safety zone for bicyclists or pedestrians to utilize.

$>$ Little Bicycle Parking - Few places to store a bicycle at likely destinations. 


\section{Opportunities}

$>$ Health Promotions - Exercise improves overall health of the general public

$>$ Growing and Aging Population - Will need new support pedestrian support infrastructure.

$>$ Environmental Stewardship - Decreasing automobile use will reduce pollution.

$>$ Cost and Infrastructure Savings - Bicycle and pedestrian infrastructure is cheaper to build and maintain than roadways for automobiles.

\section{Summary of Existing Pedestrian Infrastructure}

The City of Lake Charles has 881 individual segments of sidewalks totaling 323.5 miles. The area with the most complete sidewalk coverage is in the downtown area and in the numbered streets and boulevards between Broad Street and I-210. The areas which had neighborhoods that were lacking in a complete sidewalk network were located north of I-10, south of I-210, as well as east of I-210. The area with the least sidewalk coverage were located south of I-210 and west of Lake Street. The local roads in this area offer little to no sidewalks and the major roads in this area often have open ditches without any sort of bicycle or pedestrian support. Please refer to figure 7 for map of existing sidewalks.

\section{$\underline{\text { Summary of Conditions }}$}

\section{Width}

The average width of sidewalk in the City of Lake Charles is $4 \mathrm{ft}$. While the current national standard is $5 \mathrm{ft}$, many of the sidewalks built in the City were constructed during a time when $4 \mathrm{ft}$ was acceptable. The new sidewalks that were observed did comply with the $5 \mathrm{ft}$ standard. The width of the sidewalks located around schools and parks should have been between 6-8 ft, to allow for higher pedestrian traffic, but were not noticeably wider than those of the surrounding area. The CBD area of the city did have sidewalks of $8 \mathrm{ft}$, but were sometimes obstructed by telephone poles, which should be buried.

\section{Buffer}

Many sidewalks in residential areas had large buffers that were well over the $6 \mathrm{ft}$ national standard. While many sidewalks located on local streets provided ample buffer width, the busier streets and those located in commercial districts such as Ryan Street, Common Street, and those in the CBD offered no buffer or landscaping. These sidewalks were placed all the way to the roadway curb, making them uncomfortable when walking next to heavy traffic.

\section{Speed Limit}

Most of the speed limits observed were $25 \mathrm{mph}$. Only a few sidewalks were located on roadways with speed limits of $30 \mathrm{mph}$ or above. These low speed limits make it attractive for pedestrians to traverse the city without worrying about speeding cars.

\section{Pavement}

On a 1-5 scale, with 1 being the worst and 5 being the best, all existing sidewalks were surveyed for pavement condition. Only few sidewalks were observed with the ranking of 5 and none received the mark of 1 . The sidewalks that obtained the ranking of either 4 or 2 seemed to be clustered within the 
same area, suggesting the age of the neighborhood has a direct affect on the quality of pavement. Refer to table 7 (pg. 20) for a list of sidewalks in need of pavement improvements.

\section{Landscaping}

On a 1-5 scale, with 1 being the worst and 5 being the best, all existing sidewalks were surveyed for landscaping condition. There were many neighborhoods throughout Lake Charles that had very well maintained landscaping on sidewalks and received a mark of 4 . On the other hand, the majority of homes needed edging and trimming around their sidewalks and received the mark of 3 . The places that received a mark of 2 were mainly located around abandoned lots or in areas were development was sparse. Only a few places received a mark of 1 and were completely overgrown. No sidewalks were observed that provided street trees or bushes, therefore no sidewalk in the city received a mark of 5 for landscaping. Refer to table 8 (pg. 21) for a list of sidewalks in need of landscaping improvements.

\section{Summary of Existing Bicycle Infrastructure Bicycle Routes}

The City of Lake Charles currently has a bicycle route system comprised of 10 roadway segments. The location of the network is mostly located around the downtown area, but does also reach south down to 1-210. According to AASHTO, shared lanes should be located on roads with vehicle volumes of under 10,000 per day and travel speeds of $30 \mathrm{mph}$ or less. Following these standards, six out of the ten of the current bicycle network are not appropriate to be classified as bicycle routes. The high roadway traffic volumes or travel speeds mean that only the most advanced riders should attempt riding on streets such as Shell Beach Dr or Lake St. The route designed previously by the city was well thought out and most of the roads in the current bicycle route network are included in the new recommendations for a bikeway network, although improvements are suggested; such as additions of bicycle lanes and corresponding roadway redesign or widening. Refer to table 9 (pg. 24) for a list of improvements needed to the existing bicycle route network.

\section{Bicycle Lanes}

There are no official bike lanes within the city limits of Lake Charles, though there is one south of the city on Gauthier Rd. This bike lane is $6 \mathrm{ft}$ wide and runs east-west for 2.75 miles between Big Lake Rd and Lake St. While the length and width of this bike lane is impressive, there are no other bike lanes or bike routes connecting to this segment. This could serve as a vital and much used east-west connection for the southern portion of Lake Charles if connections to a supporting bicycle network were made.

\section{Regional Connections with Existing Shoulder Available}

There are a few state highways running through Calcasieu Parish that have shoulders that are at least 4 feet wide, which is the minimum adequate space for a bike rider. While these roadway shoulders are not marked for bicyclists specifically, they do provide sufficient space for advanced and, in some cases, basic skill-level riders. These existing roadways can be used to build connections between communities in the Lake Charles Metropolitan Area. Table 10 (pg. 25) and Figure 8 (pg. 26) showcase available regional connections. 


\section{Goals and Policy Recommendations (Chapter 4)}

The Louisiana Bicycle and Pedestrian Master Plan recommends that each municipality or jurisdiction prepare, adopt, and implement a comprehensive bicycle and pedestrian plan. Through these goals, policies, and action items, the Bicycle and Pedestrian Master Plan places a greater emphasis on bicycles and pedestrians in the Parish's ongoing work of shaping streets and managing traffic. This emphasis on bicyclists and pedestrian considerations parallels new policies within the USDOT. In early 2010, the U.S. Secretary of Transportation Ray LaHood commented on the importance of including bicycling and other alternative modes in the planning process. "Today I want to announce a sea change, this is the end of favoring motorized transportation at the expense of non-motorized...Walking and biking should not be an afterthought in roadway design."

The characteristics that make up a pedestrian and bicycle friendly environment have been grouped into five main categories: connectivity, travelway character, context character, education, and safety. These categories are the basis of the goals and policies that are detailed in Chapter 4.

\section{Connectivity}

Connectivity refers to the bikeway and pedestrian network. A well-connected network of streets and pedestrian ways means that it is easy for bikes and pedestrians to get around. Connectivity includes support for safe, convenient street crossings. Walking and transit go hand in hand - transit riders typically supplement their trip with some form of pedestrian travel at both ends.

\section{Travelway Character}

Travelway character refers to the bikeway space between automobile travel lanes and curbs, as well as sidewalk space. Roadway space can be designed to serve traffic while still providing a high-quality bicycle and pedestrian environment. The design of the sidewalks and bike lanes and the elements within it are key parts of creating a bicycle and pedestrianfriendly environment. This requires more than just minimum width requirements. Sidewalks are multifunctional, and their design should reflect the need to provide walking space as well as accommodating small children riding their bikes.

\section{Context Character}

Context Character refers to the way the adjacent land-uses interact with the pedestrian or bicyclist. A pedestrian friendly environment should have a positive relationship to an area's land use, such as food services and places to stop and rest. 


\section{Education}

Part of the success of making a place where walking a bicycling are commonplace will come from educating walkers, bikers, and automobile drivers about state and local laws. The goals for education should seek to inform citizens of the City about creating a role for walking and bicycling to contribute positively into the social cohesion of the community.

\section{Safety}

Safety goals address the need to create safe, visible, and convenient bikeway and sidewalk conditions. Factors such roadway crossings, internal site circulation, seamless access to transit, and truly multimodal streets go into account for the quality of safety for both pedestrians and cyclists.

\section{Method for Prioritizing Projects (Chapter 5)}

Limited resources such as time, land, and money, necessitate the need to create a prioritized and phased list of potential projects. This is a requirement of the Metropolitan Transportation Plan; which places potential transportation infrastructure in a timeline for funding. Many computer programs, such as GIS, and aerial photography were used to collect and analyze data with the goal of ranking the most beneficial and affordable projects. Four overarching factors were considered when creating a prioritized list of projects.

1. Generator Score - This score is related to the propensity of a particular area to generate pedestrians or bicyclists. Census Block Groups (CBGs) ranked on criteria that would preclude the assumption for pedestrians or bicyclists to be present, such as presence of persons under 16 years of age and household income. Scores were placed on a 1 (worst) to 9 (best) scale.

2. Attractor Score - The attractor score is related to the propensity of a particular destination to be attractive for pedestrians or bicyclists. Some places are more likely to for people to walk or bike to than to drive. Examples of these destinations include schools, civic buildings, and parks. Each attractor was given a value and then an approximately $1 / 4$ mile was placed around it. The areas with the highest amount of attractors had the highest value scores. Scores were placed on a 1 (worst) to 10 (best) scale. This category has an added weighted factor of 2.

3. Connectivity - Number of existing sidewalks or bike lanes the project would connect to. This is important in order to promote sidewalk continuity. There is no added weighted factor added to this category.

4. Affordability and Ease - Some projects are bound to be more costly and difficult to implement than others. This category is to try and identify the "lowest handing fruit" of potential projects. The estimated cost of the project based the factors of cost of materials and construction, filling in of ditches, and overcoming barriers such as bridges. Set on a scale of 1 (worst) to 5 (best). This category has an added weighted factor of 2 . 


\section{Recommended Pedestrian Facilities \& Bicycle Network (Chapter 6)}

A list of potential projects was compiled by following recommendations and suggestions from the public and analysis of gaps in the existing network. The projects were then ranked utilizing the four scores explained in chapter 5 , the methods section. The projects with the highest cumulative scores were ranked the highest. The recommended facility and route network was divided into three categories, pedestrian facilities, bikeway network, and trails/connectors network. Each category is described in greater detail, with a table of the recommended improvement projects and an accompanying map supplied on the following pages.

\section{Pedestrian Facilities}

Sidewalks serve as the backbone of the non-motorized transportation network. They need to be placed close to the origin (homes) of users and continue uninterrupted to their likely destination (school, job, etc.). Sidewalk accessibility and continuity should be held in high esteem. Almost 150 new sidewalk recommendations were made. Because of this large number, only the ones which were ranked in the "high" category are listed in the table below.

Highly Ranked Pedestrian Improvement Projects

\begin{tabular}{|c|c|c|c|}
\hline Map \# & Sidewalk Name & Segment Extents & Section of City \\
\hline 2 & Pear St. East Side & Medora St. to Fitzenreiter Rd. & North \\
\hline 3 & N. Simmons St. East Side 2 & Medora St. to Fitzenreiter Rd. & North \\
\hline 6 & N. Booker St. East Side & Moeling St. to Knapp St. & North \\
\hline 7 & Medora St. North Side & N. Prater St. to N. Booker St. & North \\
\hline 8 & Medora St. South Side & N Booker St to N Simmons St & North \\
\hline 9 & Woodring St North Side & N Booker St to N Simmons St & North \\
\hline 10 & Woodring St South Side & N Booker St to N Simmons St & North \\
\hline 11 & Griffin St South Side & N MLK Hwy to Sally Mae St & North \\
\hline 12 & Katherine St South Side & N Prater St to N Booker St & North \\
\hline 15 & N. Blake St. West Side & Moeling St. to Geiffers St. & North \\
\hline 16 & N. Blake St. East Side & Moeling St. to Geiffers St. & North \\
\hline 17 & N. Shattuck St. East Side & Moeling St. to Opelousas St. & North \\
\hline 18 & N. Simmons St. West Side & Moeling St. to Opelousas St. & North \\
\hline 19 & N. Simmons St. East Side & Moeling St. to Opelousas St. & North \\
\hline 20 & Cessford St. North Side & N. Prater St. to N. 1st ave. & North \\
\hline 21 & Opelousas St. South Side & N. Shattuck St. to N. Simmons St. & North \\
\hline 23 & Connecting Pedestrian Path & Connecting N. Shattuck w/ Fournet St. & North \\
\hline 25 & N. Ryan St East Side & S Railroad Ave to Jackson St & North \\
\hline 28 & Enterprise Blvd. West Side & Mill St. to Belden St. & Central \\
\hline 29 & S Shattuck St East Side & Belden St to Carter St & Central \\
\hline 35 & Pine St. North Side & Bank St to Louisiana Ave & Central \\
\hline 36 & Pine St. South Side & Bank St to Louisiana Ave & Central \\
\hline 37 & Evans St South Side & S Shattuck St to Prater St & Central \\
\hline 41 & Division St North Side & Bank St to Louisiana Ave & Central \\
\hline 42 & Division St South Side & Bank St to Louisiana Ave & Central \\
\hline 43 & Louisiana Ave West Side & Division St to Clements St & Central \\
\hline 45 & Broad St. North Side & VE Washington Ave to 1st Ave & Central \\
\hline 48 & Enterprise Blvd. West Side 2 & Broad St to Existing Sidewalk & Central \\
\hline
\end{tabular}




\begin{tabular}{rlll}
\hline 49 & Enterprise Blvd. East & Broad St to Existing Sidewalk & Central \\
59 & 5th St. North Side & Louisiana Ave to Enterprise Blvd & Central \\
60 & 5th St. South Side & Louisiana Ave to Existing Sidewalk & Central \\
63 & 1st Ave. East Side 2 & Broad St to 12th St & Central \\
67 & Common St. West Side & Clarence St to 17th St & Central \\
72 & 12th St. North Side 2 & Gerstner Memorial Dr to Russell St & South-Central \\
73 & 12th St. South Side & Gerstner Memorial Dr to Russell St & South-Central \\
75 & Moss St. East Side & 12th St. to 15th St. & South-Central \\
82 & Bank St. West Side & Gulf St. to 12th St. & South-Central \\
83 & Bank St. East Side & Gulf St. to 12th St. & South-Central \\
84 & 1st Ave. West Side & 12th St to E Prien Lake Rd & South-Central \\
85 & 1st Ave. East Side & 12th St to E Prien Lake Rd & South-Central \\
87 & 18th St. South Side & Ryan St. to Common St. & South-Central \\
90 & E Prien Lake Rd North Side 2 & Kirkman St to Existing Sidewalk & South-Central \\
91 & E Prien Lake Rd North Side 3 & Burton St to 2nd Ave. & South-Central \\
93 & Kirkman St West Side & Prien Lake Rd to Walters St & South-Central \\
94 & Kirkman St East Side & Prien Lake Rd to Madeline St & South-Central \\
100 & Madeline St South Side & Common St to Kirkman St & South-Central \\
109 & Cypress St West Side & Louie St to W 18th St & South \\
110 & Cypress St East Side & Louie St to W 18th St & South \\
111 & Hazel St West Side & W 18th St to Penn St & South \\
112 & Hazel St East Side & W 18th St to Penn St & South \\
144 & Overhill Dr North Side & Central Pkwy to Existing Sidewalk & South \\
145 & Overhill Dr South Side & Central Pkwy to Existing Sidewalk & South \\
& & & \\
\hline
\end{tabular}




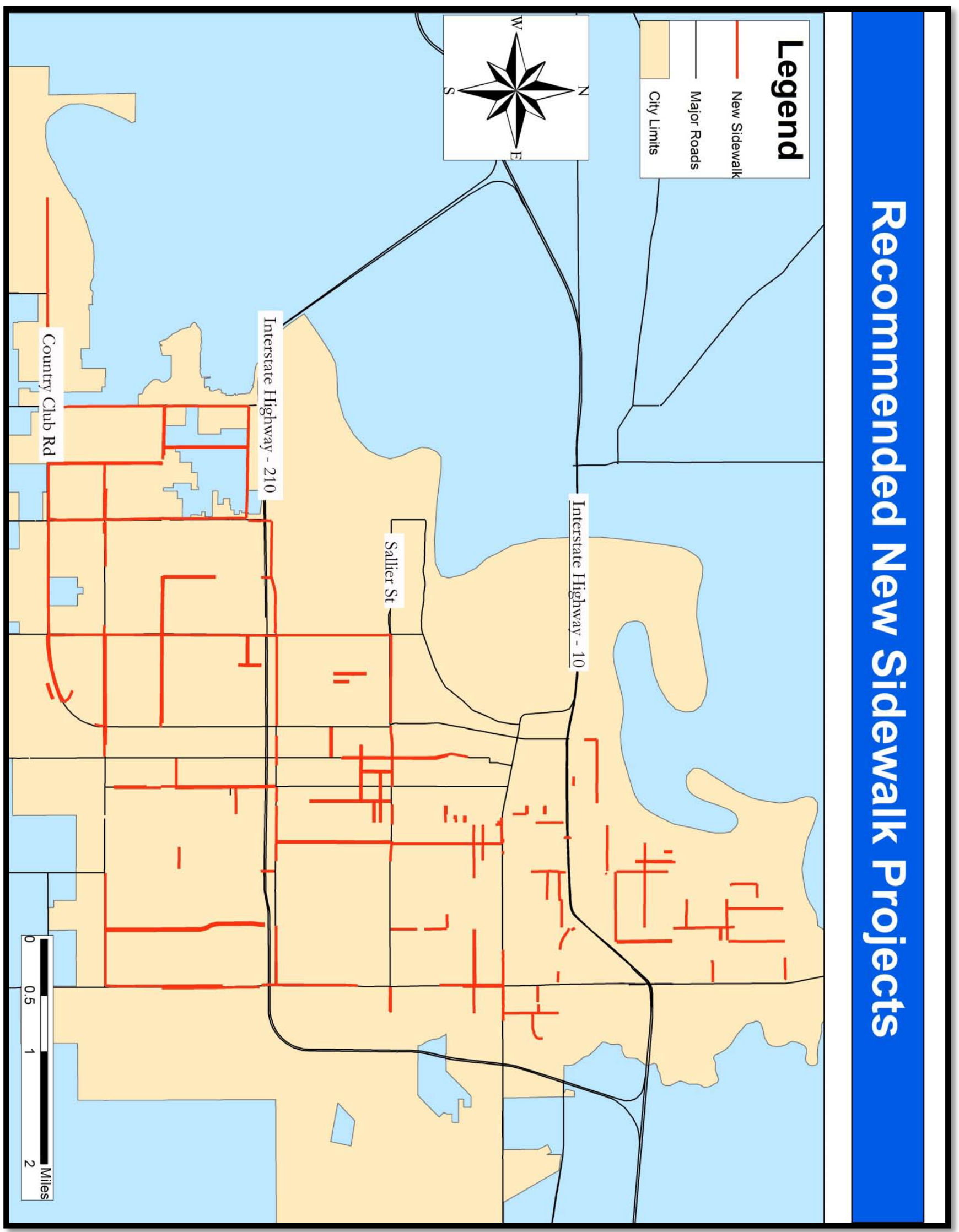




\section{Bikeway Network}

Bicyclists can travel further distances at faster speeds than pedestrians so the bikeway network can be larger in scale than the sidewalk network. There are three factors to consider when planning for bikeways: speed of traffic, volume of traffic, and width of roadway. These three factors were paramount to the selection, proposed improvements, and overall ranking of each project. The projects chosen were meant to connect schools, parks, businesses and neighborhoods within the City.

\begin{tabular}{|c|c|c|c|c|}
\hline $\begin{array}{l}\text { Map } \\
\#\end{array}$ & Road Name & Segment Extents & Priority & $\begin{array}{l}\text { Bicycle Facility } \\
\text { Recommended }\end{array}$ \\
\hline 1 & Fitzenrieter Rd. & N. Prater to N.Simmons & Moderate & Shared Lane \\
\hline 2 & Fitzenrieter Rd. 2 & N. Simmons St. to Hwy 171. & Moderate & Bike Lane \\
\hline 3 & N. Prater St. & Opelousas St. to Fitzenrieter Rd. & High & Shared Lane \\
\hline 4 & N Simmons St. & Fitzenrieter Rd. to Opelousas St. & High & Bike Lane \\
\hline 5 & N. Goos Blvd. & Opelousas St. to Theriot Rd & High & Bike Lane \\
\hline 6 & Moeling St. & N. 1st Ave. to Hwy 171 & High & Bike Lane \\
\hline 7 & N. 1st Ave. & Moeling St. to N. Railroad Ave. & High & Shared Lane \\
\hline 8 & Opelousas St. & N. Enterprise Blvd. to Hwy. 171 & High & Bike Lane \\
\hline 9 & N. Railroad Ave & N. Bilbo St. to N. 1st Ave. & Moderate & Shared Lane \\
\hline 10 & N. Ryan St & Jackson St to W Mill St & Moderate & Bike Lane \\
\hline 11 & N. Kirkman St & N Railroad Ave to I-10 Svc Rd & Low & Shared Lane \\
\hline 12 & South Shattuck & Broad St. to Opelousas St. & High & Bike Lane \\
\hline 13 & W Mill St & Veterans Memorial Dr to Goos St & High & Shared Lane \\
\hline 14 & E Mill St & Goos St to Hwy 171 & Moderate & Shared Lane \\
\hline 15 & Hodges St. & Alamo St. to Belden St. & High & Shared Lane \\
\hline 16 & Kirkman St. & N. Railroad Ave to College St & High & Bike Lane \\
\hline 17 & Kirby St. & Lakeshore Dr. to Bord Du Lac & Moderate & Bike Lane \\
\hline 18 & Kirby St 2 & Ryan St to Louisiana Ave & High & Bike Lane \\
\hline 19 & 2nd St. & Louisiana Ave. to 3rd Ave. & Moderate & Shared Lane \\
\hline 20 & Shell Beach Dr. & Clarence St. to Lake St. & Low & Bike Lane \\
\hline 21 & Alvin St. & Shell Beach Dr. to Dr. Debakey Rd. & Moderate & Bike Lane \\
\hline 22 & Dr. Debakey Dr. & Lake St. to Ryan St. & Moderate & Bike Lane \\
\hline 23 & 1st Ave & Broad St to 12th St & High & Bike Lane \\
\hline 24 & 7th St. & Ryan St. to 4th Ave. & High & Shared Lane \\
\hline 25 & 11th St. & Ryan St. to 4th Ave. & High & Shared Lane \\
\hline 26 & Lake St. & Shell Beach Dr. to Country Club Rd. & Moderate & Bike Lane \\
\hline 27 & 1st Ave 2 & 12th St to E Prien Lake Rd & Moderate & Shared Lane \\
\hline 28 & 14th St. & Enterprise Blvd. to Gerstner Memorial Hwy & Moderate & Shared Lane \\
\hline 29 & 18th St. & Common St. to Gerstner Memorial Dr & Low & Shared Lane \\
\hline 30 & Alamo St. & Ryan St. to Enterprise Blvd. & Moderate & Bike Lane \\
\hline 31 & W Prien Lake Rd. & Lake St. to Nelson Rd. & Low & Bike Lane \\
\hline 32 & College St. & Lake St. to 5th Ave. & Low & Bike Lane \\
\hline 33 & E Prien Lake Rd & Gerstner Memorial Hwy to Corbina Rd Ext & Low & Shared Lane \\
\hline 34 & Nelson Rd. & W. Prien Lake Rd. to Country Club Rd. & Low & Bike Lane \\
\hline 35 & Kirkman St. 2 & College St to E McNeese St & Moderate & Bike Lane \\
\hline 36 & W. Sale Rd. & Ihles Rd. to Ryan St. & Low & Bike Lane \\
\hline 37 & E. Sale Rd & Ryan St. to Common St. & High & Bike Lane \\
\hline 38 & Ryan St. & W. Sale Rd. to W. McNeese St. & Moderate & Bike Lane \\
\hline 39 & Common St. & E Sale Rd to McNeese St & Low & Bike Lane \\
\hline 40 & McNeese St. & Nelson Rd. to 5th Ave. & Moderate & Bike Lane \\
\hline
\end{tabular}




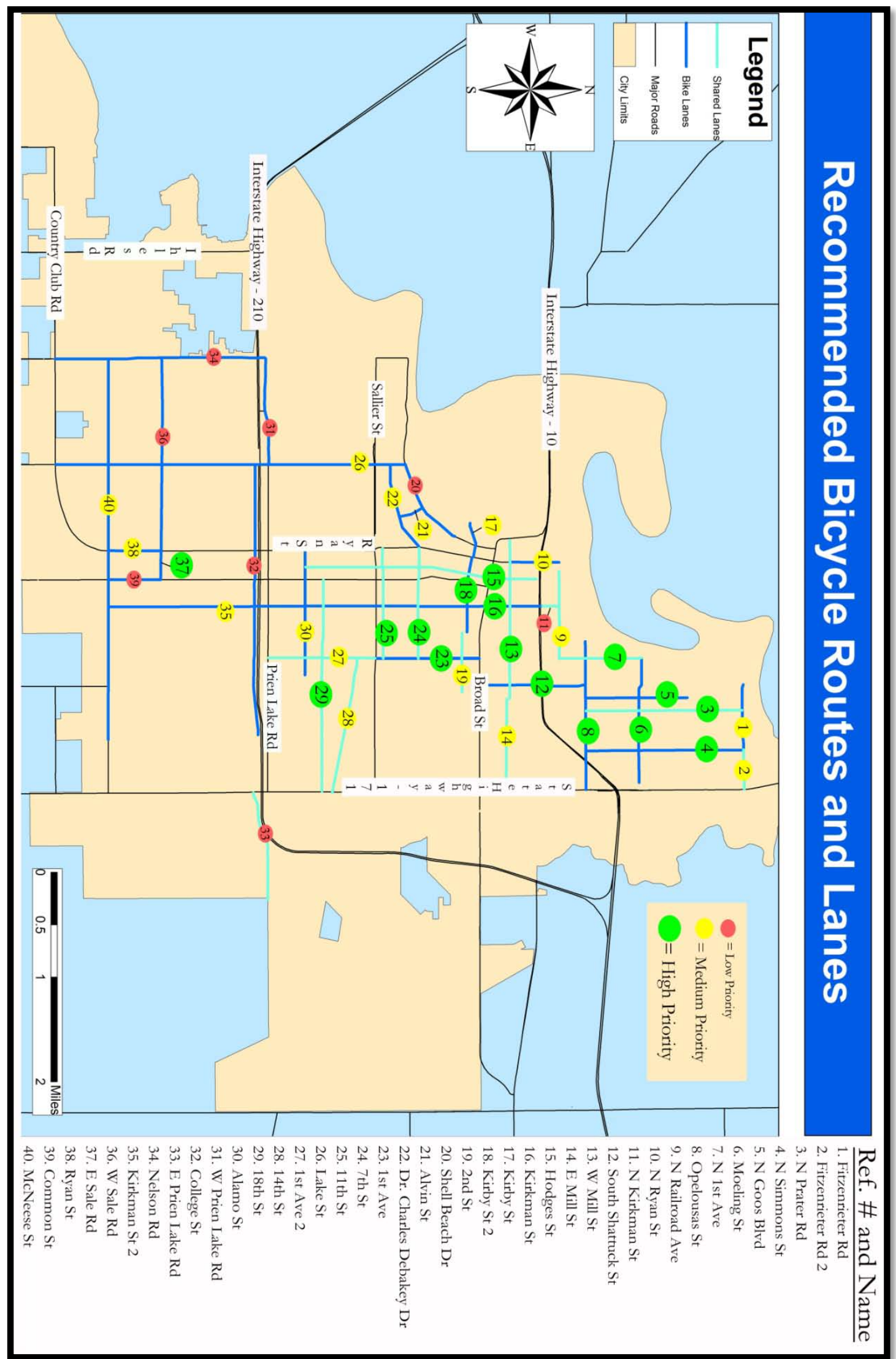




\section{Path/Trail Network}

Sidewalks and bikeways are necessary components for a complete transportation network, but they do not serve the needs of all residents. Paths and trails can serve as short-cuts through neighborhoods or connect communities. They also serve to improve safety for less experienced riders because they are completely separated from automobile traffic. A total of five potential city-wide trails and five local paths/shortcuts were identified. If constructed, these trails would provide an almost unbroken pathway for non-motorized types running between north and south Lake Charles. This could serve to improve the health and well-being of all Lake Charles residents.

Recommended Path/Trail Network

\begin{tabular}{llr}
\hline Name of Trail/Connector & Extents & Length \\
\hline Perkins Ferry Trail & N. Railroad Ave to Perkins Ferry Park & 2 \\
1st Ave Trail & Railroad Tracks to 12th St & 1.75 \\
Lakeshore Canal Trail & Lakeshore Dr to Common St & 0.6 \\
Railroad Connector Trail & 1st Ave to 5th Ave & 0.75 \\
5th Ave Trail & 12th St to McNeese St & 2.5 \\
N. Railroad Ave Connector & N Railroad Ave to N Ryan St & 0.1 \\
13th Ave Connector & 13th Ave to Gersnter Mem Dr & 0.1 \\
5th Ave Circuit Connector & 5th Ave to 5th Ave & 1 \\
5th Ave Connector & 5th Ave Circuit to Gersnter Mem Dr & 0.25 \\
Parkway St Connector & McNeese St to Common St & 0.5 \\
\hline
\end{tabular}

\section{Recommended Trails, Paths, and Stagging Areas}

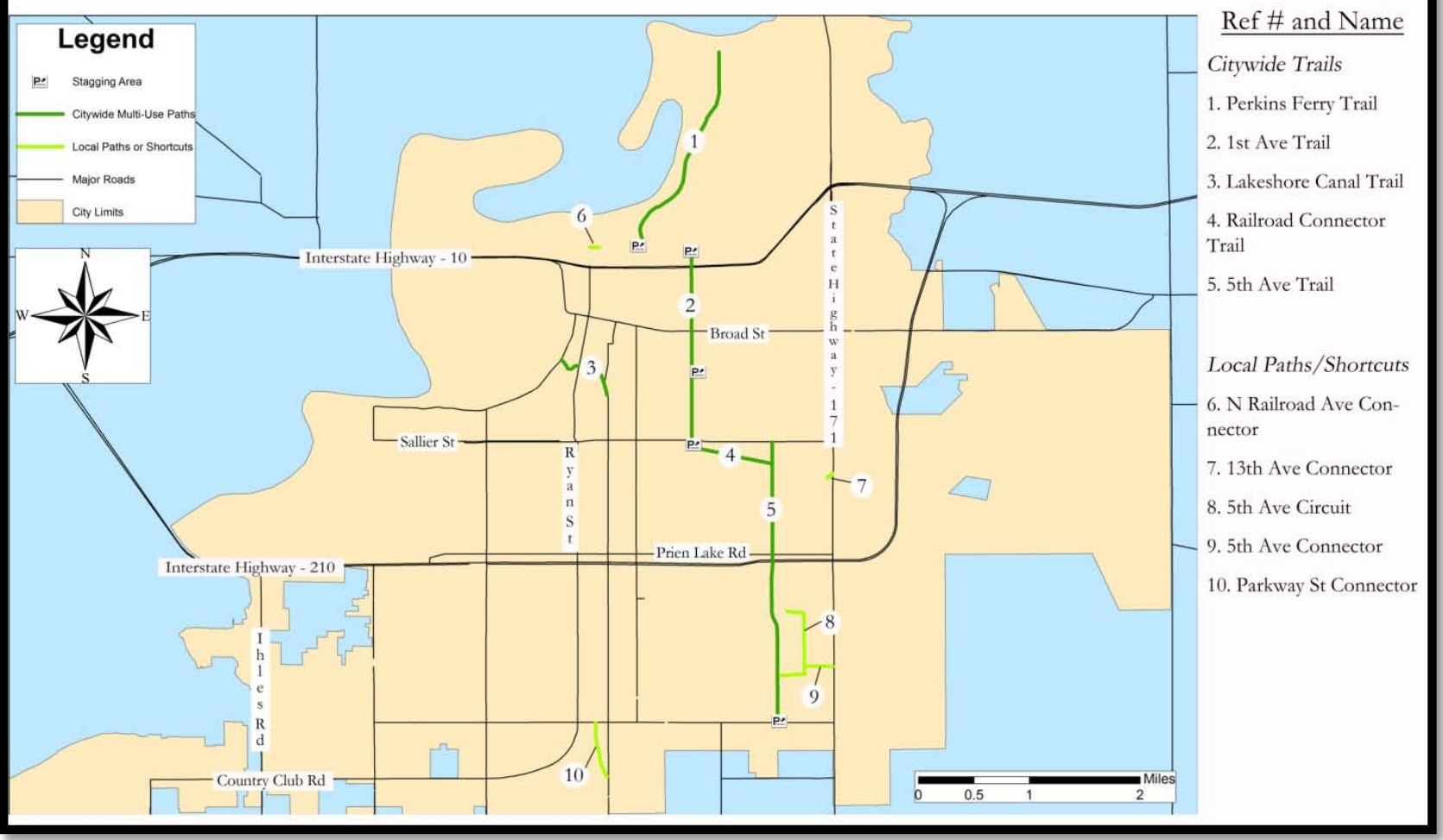




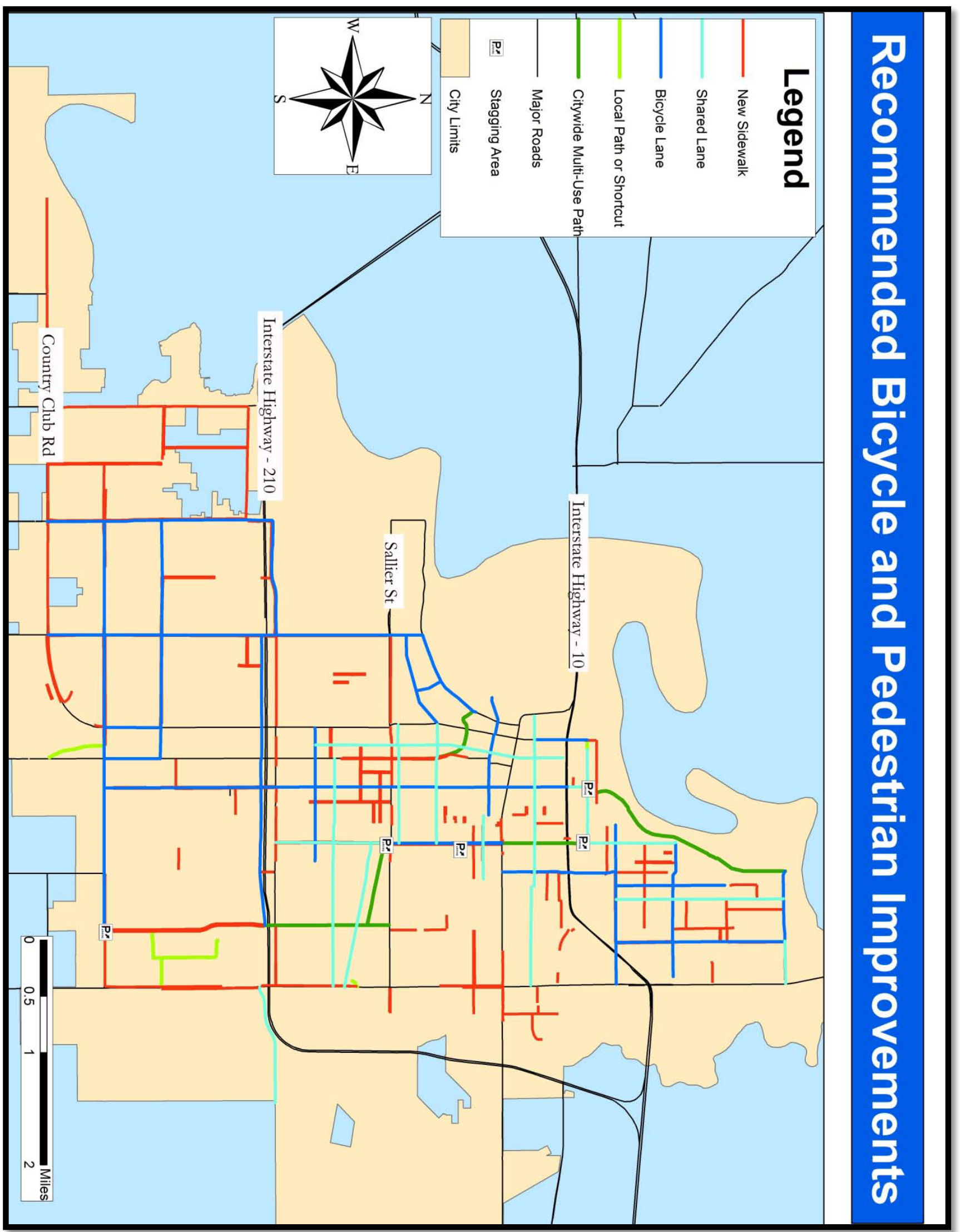




\section{Implementation and Funding (Chapter 7)}

Plans must be implemented in order to make a difference. The following steps are suggested to take place after a project has been identified for improvement.

- Field Verification: Field verification should include a review of existing conditions (such as available right-of-way, adjacent land uses, and pedestrian volumes) and identifying potential design constraints (such at locations of utilities).

- Design Improvements: Appropriate sidewalk improvements should be designed after projects have gone through the field verification process.

- Deliver Project: The final step of the implementation program process will be to construct the new improvement project

\section{Funding Sources}

- $\quad$ Safe Routes to School - Funding source for improvements made within walking distances of schools.

- SAFETEA-LEAU - Federal roadway improvement program, which gives $90 \%$ funding for improvement programs that incorporate planning for pedestrians or bicycles.

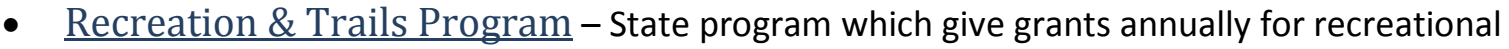
trail program.

- Local Road Safety Improvement Program - State program which gives small grants for projects which improve bicycle or pedestrian safety.

- Rails to Trails - Private organization which helps to guide funding for development of converted abandoned railroad tracks into trails. 


\section{Chapter 1: Introduction}

Nationwide, people are recognizing the energy efficiency, cost effectiveness, health benefits and environmental advantages of leaving the car behind. Walking and biking are forms of transportation that are enjoyable, energizing, environmentally friendly, and free. Nationally, interest in alternate modes of transportation was first emphasized in the Intermodal Surface Transportation Efficiency Act (ISTEA) of 1991, and has been gaining traction ever since. In 2010, Secretary of Transportation Secretary Ray LaHood wrote, "... I want to announce a sea change, this is the end of favoring motorized transportation at the expense of non-motorized." Local, state and federal agencies are responding to this call for an improved process of planning for pedestrian and bicycle travel by implementing a multimodal approach to roadway design. The emphasis now being placed on alternative forms of transportation requires an understanding of bicycles, pedestrians and their subsequent facilities.

This plan takes a look at the existing City of Lake Charles roadway network, builds upon the previous planning foundations, and makes recommendations to enhance and expand the existing on-street bikeway network, connect gaps in sidewalks, address constrained areas, provide for greater local and regional connectivity, and encourage more residents to use non-motorized modes of transportation. Since the City of Lake Charles wants to encourage more people to bike or walk, it needs to put in place policies that promote a bicycle and pedestrian-friendly development. This Plan will recommend a variety of policies to allow for safe, efficient, and convenient pedestrian and bicycle travel in and between the communities of The City of Lake Charles.

\section{Vision and Purpose of the Plan}

\section{Vision}

"To promote Lake Charles as a bicycle and pedestrian-friendly environment by providing a variety of transportation choices that promote accessible alternatives to the automobile; where public spaces, including streets and off-street paths, will offer a level of convenience, safety and attractiveness that will encourage and reward the choice to bike or walk."

\section{Purpose}

This plan is being developed in accordance with the Louisiana Statewide Pedestrian and Bicycle Master Plan. This plan is meant to serve as a guide for local decision-makers and the public in how best to plan for alternative modes of transportation in future development. It accomplishes this by conducting a comprehensive inventory and analysis of existing bicycle and pedestrian facilities within Lake Charles and provides a prioritized list of potential improvements. Suggested improvements will incorporate sidewalks, bike routes, bike lanes, and multi-use recreational trails into a comprehensive network with the goal of increasing access and mobility for non-motorized modes of travel. 


\section{Why Develop a Bicycle and Pedestrian Master Plan?}

While we can probably think of many reasons why it would be beneficial to plan for bicyclists and pedestrians we cannot name them all. A list of five overarching justifications for creating The City of Lake Charles Bicycle and Pedestrian Master Plan were created. They are explained in detail below.

\section{Expand the Network and Support Facilities for All Residents}

Implementing a pedestrian and bikeway network that links a variety of destinations - employment, shopping, school, and recreation - is a key to supporting all segments of the population, especially children, the disabled, and the elderly. In addition to expanding and connecting key routes, providing support facilities such as clear directional signage and secure bicycle parking will enhance the functionality of the network and encourage more people to recreate.

\section{Enhance the Quality of Life in Lake Charles}

The development of bicycle and pedestrian facilities creates people-friendly streets, paths, trails, and activity centers that are accessible and available to everyone and supports sustainable community development. Non-motorized travel reduces traffic congestion, vehicle exhaust emissions, noise, and energy consumption. It is a healthy and active form of travel. It is an affordable means of transportation and recreation. Safe and efficient walking and cycling opportunities will attract residents and tourists to scenic areas or surrounding businesses.

\section{Improve Safety and Encourage Alternative Modes}

The design standards and guidelines, education, and enforcement recommendations outlined in this plan are meant to serve as tools to enhance safety for bicyclists and pedestrians. This plan provides recommendations for route improvements intended to make movement safer for bicyclists and pedestrians of all ability levels. Encouragement programs are also suggested to motivate residents to ride or walk to work, school, or exercise and recreation.

\section{Traffic and Growth Management}

Developing a multimodal transportation system will address traffic congestion, air and water pollution, energy consumption, problems with near-exclusive use of automobiles, use of non-renewable fuels to supply transportation, and increased pressure on infrastructure budgets to build and maintain roads.

\section{Maximize Funding Sources for Implementation}

With the identification and prioritization of specific facility and programmatic improvements found in this plan, the City and other local jurisdictions can apply for appropriate funding to support bicycling and walking throughout the region. 


\section{Why Bicycling and Walking?}

Figure 1: Walking and Biking

The walking and bicycling are the lowest-cost and most effective means of transportation. Furthermore they are non-polluting, energy-efficient, versatile, healthy, and fun. They also offer low-cost mobility to the non-driving public, such as those under 16 or those over 65 . Bicycling as a means of transportation has been growing in popularity and many communities are working to create a more balanced transportation system, by giving bicyclists a greater share of use in roadway networks. In addition, recent national surveys find that more people are willing to cycle more frequently if better bicycle facilities are provided.

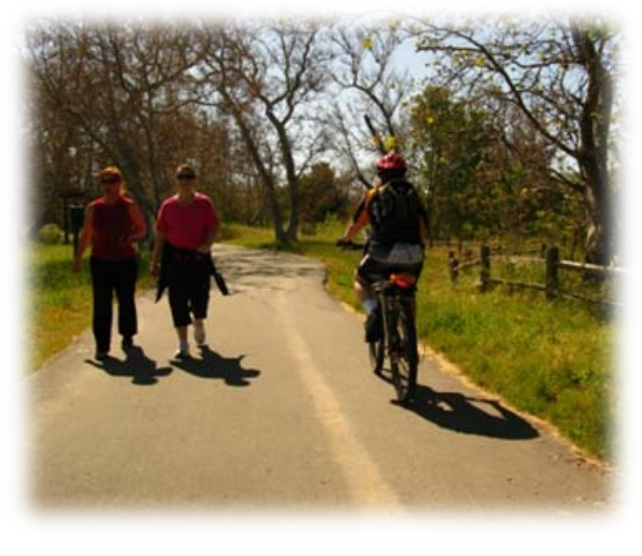

The City of Lake Charles and the surrounding metro area is expected to growing at a moderate rate in the future. Traffic congestion is not yet a problem in some parts of the the City, but it can be seen in certain areas such as Lake Street and Prien Lake Road. Managing traffic by offering alternative modes is a key strategy to reducing automobile congestion and to ensure communities maintain their existing character. This Plan is one step toward providing alternative modes and addressing future traffic congestion in the City.

Another reason for encouraging and promoting bicycling and walking is the enjoyment and quality of life it brings to the residents of our City and the ability for them to take advantage of the natural beauty and scenic quality of the region. Bicycling and walking are among the most popular forms of recreational activity in the United States, with almost 80 million people walking and 36 million people bicycling for recreation or exercise nationally, and 27.3 percent of the population over 16 are bicycling at least once over the summer. Because of its popularity, the ability for bicycling and walking to have major impact on community health is huge. This is especially true for the older segment of the population who benefit most from such low-impact forms of exercise.

Bikeway and pedestrian network enhancements are expected to generate more non-motorized trips in the future. This growth is expected to improve air quality by further reducing the number of vehicle trips, vehicle miles traveled and associated vehicle emissions. This Plan seeks to develop the bicycle and pedestrian friendly network that encourages non-motorized modes to be a practical alternative to driving for Lake Charles area residents. 


\section{Chapter 2: Plan Development Process/Outreach}

\section{Public Input Meeting}

On August $16^{\text {th }}, 2010$ a meeting was held at the Central Public Library in Lake Charles. This meeting was a publicly advertised meeting and was open to all residents in Calcasieu Parish and the Lake Charles Metro Area. Stakeholders such as public and private individuals and organizations that regularly use pedestrian and bicycle facilities within Calcasieu Parish or The City of Lake Charles were directly contacted and invited to attend the meeting. The purpose was to receive information from the public regarding which areas were in most need of bicycle and pedestrian improvements. The meeting was well attended, with 42 people joining the discussion and 36 of them who filled out the questionnaire which was provided.

The questionnaire was developed to solicit specific input on key issues and concerns regarding the pedestrian and bicycle facilities system, and to generate input regarding the most important issues to be addressed and potential priority order for types of projects and system improvement. A copy of the questionnaire can be found in Appendix B. A map was also provided which allowed them to mark and draw out the areas they thought were in most need of improvement projects. A summary of this data has been compiled into an easy to understand format below.

Figure 2: Stakeholder Map Drawing Exercise

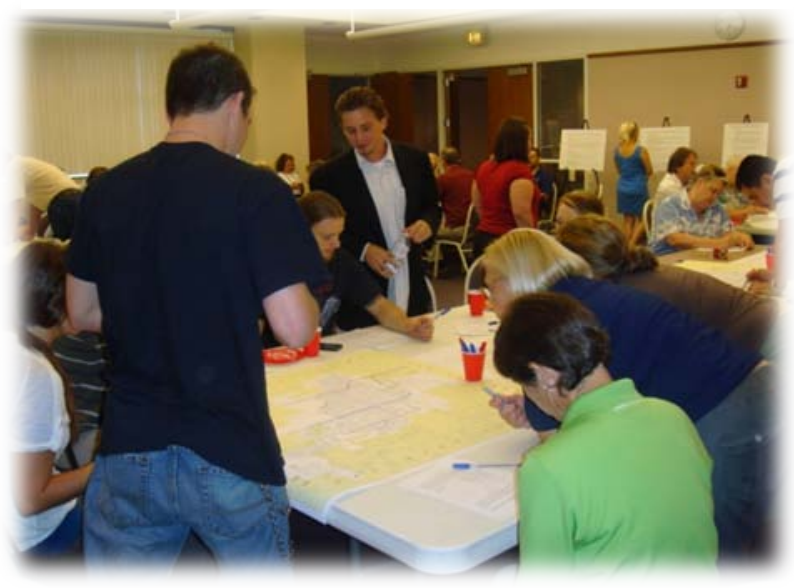

\section{Summary of Questionnaire Responses}

\section{Improvements}

Residents were asked to rank, from 1 (low) to 5 (high), which of the following categories in Table 1 are most needed. The results were added up into point totals and averages and then subsequently analyzed for trends. The purpose of this is to help prioritize which improvements are most important in the public's point of view.

All of the "Improvements" categories were added up and the scores achieved were close in their point totals. When we look the values of their averages, they appeared to cluster around each other. This result shows that the community desires a varied array of alternative transportation options. The highest total and average is bike lanes. Many participants commented that bike lanes could be used by pedestrians as well, on some of the more rural roads. This suggestion is consistent with respect to AASHTO standards that state providing a shoulder on rural roads could substitute for a sidewalk. 
Table1: Stakeholder Improvement Prioritization

\begin{tabular}{|l|c|c|c|c|c|}
\hline \multicolumn{7}{|c|}{ Improvements } \\
Category & $\begin{array}{c}\text { Sidewalk } \\
\text { Continuity }\end{array}$ & $\begin{array}{c}\text { Intersection } \\
\text { Safety }\end{array}$ & Bike Lanes & $\begin{array}{c}\text { Multi-Use } \\
\text { Trails }\end{array}$ & $\begin{array}{c}\text { Bicycle } \\
\text { Routes }\end{array}$ \\
\hline Total & 109 & 112 & 148 & 111 & 124 \\
\hline Average & 3.03 & 3.11 & 4.11 & 3.08 & 3.44 \\
\hline
\end{tabular}

\section{Attractors}

With the goal of identifying which attractors are most important or likely destinations for bicyclists and pedestrians, stakeholders were asked to rank attractors on a scale of 1 (lowest) to 5 (best). These categories were added up and their point totals and averages were analyzed. The following bullets are a summary of the results.

- A few attractors stood out as favorites for the public. "Parks" scored the highest, followed by "Recreation/Community centers", and then "Schools". These three had significantly higher point totals than the next three; "Libraries", "Post Office/Civic Buildings", and finally "Public Transportation Stops."

- These results show that this community would rather have bicycle and pedestrian access to recreational and park facilities. Children's ability to walk and bike to school were also very important. The need get to post offices or civic buildings were less important.

- Public transit scored the lowest which was not expected, but could be explained by low ridership rate. According to the 2000 Census, only $0.6 \%$ of commuters took public transit to get to work. This low commute rate may be a result of poor access to public transit stops.

Table 2: Stakeholder Attractor Values

\begin{tabular}{|l|c|c|c|c|c|c|}
\hline \multicolumn{9}{|c|}{ Attractors } \\
\hline Category & Schools & Parks & $\begin{array}{c}\text { Recreation/ } \\
\text { Community }\end{array}$ & $\begin{array}{c}\text { Post Office/Civic } \\
\text { Buildings }\end{array}$ & $\begin{array}{c}\text { Public Transit } \\
\text { Stops }\end{array}$ & Libraries \\
\hline Total & 133 & 153 & 137 & 86 & 69 & 102 \\
\hline Average & 3.69 & 4.25 & 3.81 & 2.39 & 1.92 & 2.83 \\
\hline
\end{tabular}

\section{Network Expansion and Improvement Suggestions}

During the Public Input Session a great many suggestions came forward on which roads were in most need of improvement projects. There were a total of 16 roads suggested, but only 5 of them were mentioned more than once. The roads mentioned most were Highway 378, Highway 27, Old Spanish Trial, Sutherland Road, and Highway 171. A list of the top publicly suggested improvements is shown in table below. 
Table 3: Stakeholder Suggested Improvements

\begin{tabular}{|c|c|}
\hline \multicolumn{2}{|c|}{ Lake Charles Public Suggested Improvements } \\
\hline Road Name & \# Times Suggested \\
\hline Sale Rd. & 13 \\
\hline McNeese St. & 12 \\
\hline Prien Lake Rd. & 9 \\
\hline Lake St. & 8 \\
\hline Shell Beach Dr. & 7 \\
\hline Ryan St. & 7 \\
\hline Common St. & 5 \\
\hline Gauthier Rd. & 4 \\
\hline Sallier St. Between Ryan \& Lake St. & 3 \\
\hline Enterprise Blvd & 3 \\
\hline Country Club Rd. & 3 \\
\hline Ihles Rd. & 2 \\
\hline Elliot Rd. & 2 \\
\hline Big Lake Rd. & 2 \\
\hline All Roads throughout downtown & 2 \\
\hline Weaver Rd. & 2 \\
\hline Kirkman st. & 2 \\
\hline All around McNeese & 2 \\
\hline Gulf Highway & 2 \\
\hline Nelson Rd. & 1 \\
\hline I-10 Bridge & 1 \\
\hline College St. & 1 \\
\hline Lincoln & 1 \\
\hline Burton Ln. & 1 \\
\hline 6th & 1 \\
\hline Kirby St. & 1 \\
\hline Lakeshore Dr. & 1 \\
\hline Louisiana & 1 \\
\hline Warren St. & 1 \\
\hline 5th Ave. & 1 \\
\hline 1st Ave. & 1 \\
\hline Broad St. & 1 \\
\hline Haymark Rd. & 1 \\
\hline
\end{tabular}

\section{Personal Experiences/Stories}

Respondents were asked to provide a personal experience they have had navigating the roadways of Lake Charles without an automobile. Sharing any stories that their friends or family members have told to them were also highly encouraged. The following are quotes from stakeholders who attended the public input session meeting. 
"...Start with existing sidewalks - clean up, widen, remove debris, make sure transition ramp from sidewalk to road is well done."

"Sidewalks in the downtown LC area have very high curbs. Trees cause broken sidewalks and I tripped and fell. When I walk on the road it is just as rough. I walk at an angle, cars do not want to move over."

"I think that the roads that have the heaviest motor vehicle traffic should have ped \& bicycle lanes. These are the roads people need to use to get to jobs, schools, shopping, etc. Roads that would be great are Ryan, Common, McNeese, Prienlake, and Sale. McNeese students want to ride to class also have a lot of trouble. I also think there needs to be education for motor vehicle drivers. Most drivers do not understand that they must share the road with bicycles."

“...I had a Sheriff's car yell at me over his PA system to move off of the road. He obviously did not know the law and this is not the only time it happened. This is why I feel that not only the public should be educated about biking, but law enforcement as well."

"I run daily in the downtown area and I never get on the sidewalks because they are in poor shape."

"Safety should be a primary concern...bikers are generally not able to ride on the shoulder of roads because of all of the trash on them, broken glass, tree limbs, torn up truck tires, large clumps of mud, etc...You have to either swerve to miss it or possible go down and fall in front of a car."

"The open ditches that exist on Prien Lake Rd. (south of Lake St.), Sale Rd., Weaver Rd, and Burton Ln. are extremely hazardous. If these ditches were closed...ideal multi-purpose (walking, biking) paths could be created...students could actually ride bikes to schools, parks, and churches."

“...I work at the local bike shop in town, Capitol Cyclery of Lake Charles, and talk to people everyday about why they want a bike but can't ride. People want to ride bikes but feel that it is too risky because of the fear of being hit. They even are scared of riding in their own neighborhood. If they had a multi-purpose path that connected to the heart of the city and had many outlets then the city would be more active.

"I have for many years wanted to "Walk Lake Charles" and feel that adding paths that connect the parish would bring the communities together and be a tourist attraction."

"I have had many "close calls" with vehicles while biking in the downtown area (of Lake Charles) and south of town near Gauthier, Lincoln, Lake, Tom Hebert. I believe structured bike paths, trails, and parking facilities will dramatically increase the safety of bikers and runners." 


\section{Comments and Concerns}

Many people took the time to share their comments or concerns with us and also give us their opinion about what was most important to them. These comments or concerns were categorized into a few "themes" and quantified if more than two people mentioned them.

Table 4: Comment Categories

\begin{tabular}{|c|c|}
\hline \multicolumn{2}{|c|}{ Concerns and Comments Categories } \\
\hline Comment Category & Number of Comments \\
\hline Safety Concerns & 14 \\
\hline Driver Education & 6 \\
\hline Increase Quality of Life & 5 \\
\hline Multi-Use Paths & 4 \\
\hline Bridge over Contraband Bayou & 3 \\
\hline Curbs and Ramps & 2 \\
\hline Clean Shoulders on Roadway & 2 \\
\hline Bicycles Can't Trigger Traffic Signals & 2 \\
\hline Total Stories or Comments & 33 \\
\hline
\end{tabular}

Safety appeared to be the chief concern of stakeholders who gave either a comment or concern. People mentioned safety concerns more than twice as often as any other concern. The concern with the next highest number of comments was "driver education." This category is related to safety, as uneducated drivers can present situations that are unsafe to walkers and bicyclists. The following are a few quotes taken from the Comments and Concerns section of the questionnaire.

"Sale Rd. between Lake and Nelson is horrible and very dangerous, especially over the bridge. It needs to be taken into consideration. It is not safe and the people in Lake Charles deserve better than this. Please do something!!"

"95\% of roads have no shoulders. Those with existing shoulders have rare periodic maintenance (i.e. street sweeping). There exists no interconnectivity of the few lanes that exist."

"Turn Sallier Rd. into 1/2 bike and 1/2 traffic lanes between Ryan all the way to the port. - Slow traffic on Shellbeach Dr. so pedestrians and bikers can enjoy our lake. -Improve Deathtraps on Contraband Bayou Crossings. - Add pedestrian bridge on new I-10 bridge. - Clean shoulders"

"Need bike racks on buses. Education is very important! Make 1st Ave. idea part of rails to trails. Path on new I-10 bridge."

"If we only ask for bike specific lanes then it will put a lot of people off. If we include all activities then much more people will participate." 


\section{Chapter 3: Existing Conditions}

\section{Topography and Environment}

Southwest Louisiana is fortunate to have numerous natural resources and environmental treasures. Its relatively flat topography has few grades of more than $3 \%$, which is optimal for bicycle and pedestrian travel. Making up most of the landscape outside of the urban centers, much of the area surrounding Lake Charles is covered with forests, streams, marshes, and farms. Rural sports such as hunting and fishing are commonplace and are draws for locals and tourists alike.

The Calcasieu River is the prominent natural feature in the area. It is responsible for the lake that gives the City of Lake Charles its name and a port industry that ranks in the top 10 in the nation. The Calcasieu and Sabine Rivers that run through Calcasieu Parish have created extensive waterways that afford its citizens opportunities to recreate in wonderfully natural settings.

Figure 4: Average Monthly Precipitation

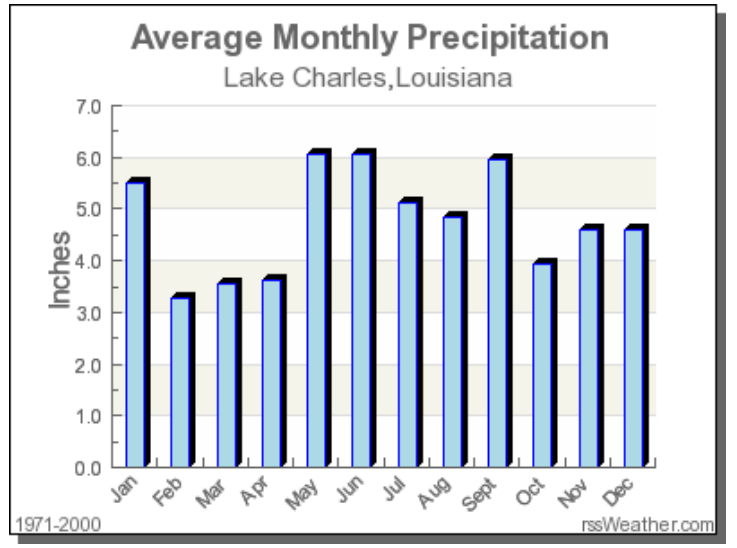

The annual rainfall for Lake Charles is 55 inches, with all months receiving roughly the same amount, as shown in figure 4 . The months with the most rain showers are the ones that tend to be the hottest. Hot days welcome cooling showers. The Gulf Coast weather pattern makes for scattered rain showers that gather and dissipate quickly making bicycle and pedestrian travel possible.

Figure 5: Average Temperature Range

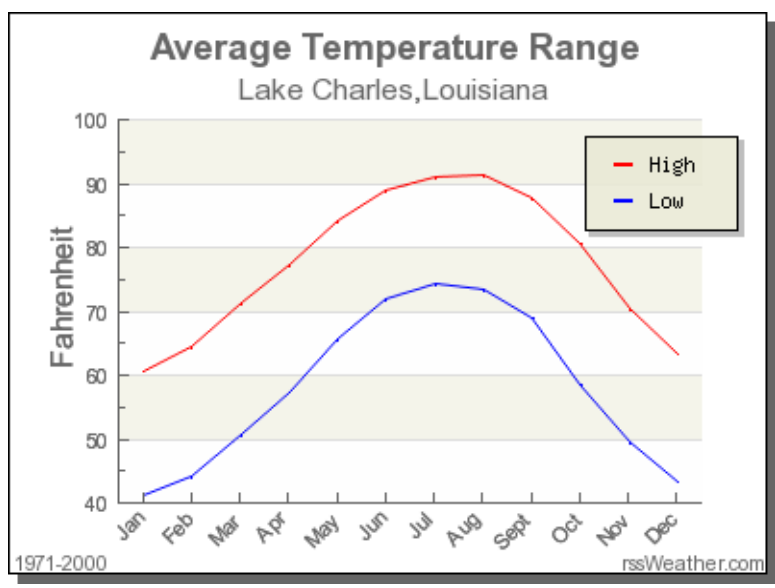


Temperature and rain are important, but sunshine is another important factor when planning a recreational trip. "Sunshine hours" refers to the amount sunshine there is during the hours of daylight. The higher percentage means there is more sunshine throughout the day and a lower percentage will indicate that it is probably cloudier. Figure 6 shows that sunshine probability ranges from $60 \%$ to $85 \%$. This sub-tropical climate of pleasant temperatures for most of the year, regular and predictable cycles of rain, and large amounts of sunshine makes recreation outdoors very attractive for much of the year.

Figure 6: Percentage of Possible Sunshine

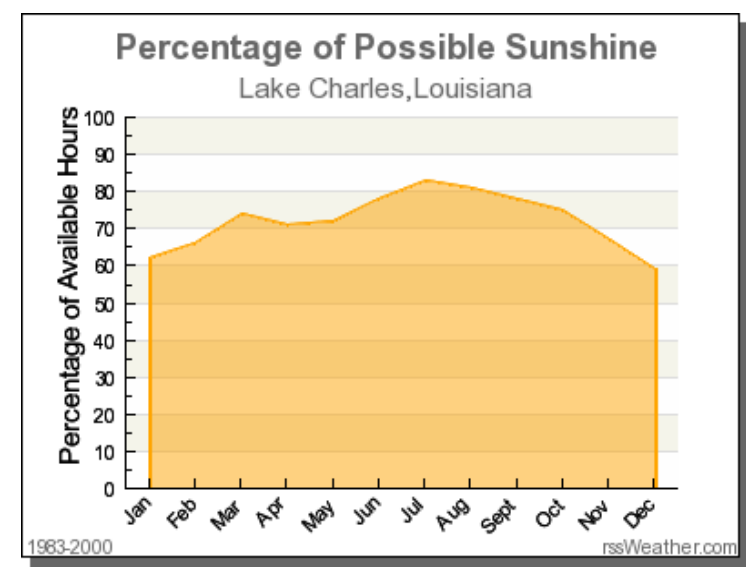

\section{Needs and Demands Analysis}

\section{Constraints and Opportunities in Calcasieu Parish}

It is important to identify what your potential problems are before you start to plan for the future. We must also consider what factors might come into play that would be seen as benefits to the community by our actions. A list has been compiled of potential constraints and opportunities in The City of Lake Charles. A description of each factor is discussed as well.

\section{Constraints}

\section{Limited Public Transit System}

The current bus system that operates in the city is limited to only six lines and only runs about once per hour. While it fills a need it does not fulfill the transportation needs of all the residents who do not own a car. This fact gives credence to the need for an improved bicycle and pedestrian support network.

\section{Waterways, Highways, and Railways}

The many canals and waterways located throughout the City are beautiful, but pose a problem because of the need to build bridges to cross them. The interstate highways and railways that run through the City also create barriers to travel that must be overcome with bridges or underpasses. While many bridges already exist on roadways, there are few which offer bicycle or pedestrian support. The I-10 and I-210 bridges expressly forbid pedestrian travel and the Hwy 171 Bridge towards Moss Bluff is narrow and vehicle traffic travels at a high rate of speed.

\section{Heavy Vehicle Traffic and Rate of Travel Speed}

The prevalence of heavy vehicle traffic and a high rate of travel speed (>35 $\mathrm{mph}$ ) creates safety concerns for bicyclists sharing a roadway. Roads with large travel volumes and high rates of speed should be avoided if possible. Because parts of Lake Charles are industrially intensive areas, special attention should be paid to which areas have high rates of heavy vehicle traffic and should subsequently be avoided by bicyclists as well. 


\section{Open Ditches}

Open ditches, which flank most roads in the southern section of the City, cause problems for cars, bicyclist, and pedestrians. Bicyclists who are riding on the roadway cannot get off the road whenever a car is coming. Pedestrians cannot walk along the roadway because there is no shoulder and ditches are often wet. Those who do not own an automobile have no path to get to their destination, paved or dirt. Covering ditches along main roadways, which connect communities, can allow for pedestrians to walk from one destination to another without worrying about speeding vehicles in the road.

\section{Bicycle Parking}

Parking for both bicycles at destinations and cars at staging areas is minimal. The designation and location of these facilities is not available to the public and is therefore difficult to recognize. A survey of bicycle parking facilities is suggested in order to better gauge which areas of the City are in need of improvements. Signage and designation of staging areas which can be used for people wishing to use bicycle facilities is also suggested.

\section{Opportunities}

\section{Growing and Aging Population}

Population growth will require expansion of roadways to accommodate new travelers, this is a perfect opportunity to add in bicycle or pedestrian support. Also, in the coming years, the aging baby boomer population will be retiring and will be looking for alternatives to driving and increased opportunities for physical activity.

\section{Environmental Stewardship}

Climate change, rising energy costs, and the effects of pollution have raised concerns about what type of transportation we use. The growing awareness of environmental impacts of transportation has led to a high level of public support for increased accommodation for walking and bicycling.

\section{$\underline{\text { Cost and Infrastructure Savings }}$}

Compared with building roadways, there is recognition of the cost effectiveness of providing pedestrian and bicycle improvements in lieu of continued automobile accommodation. It is also recognized that simply adding pedestrian and bicycle improvements as integral parts of larger projects can be done with minimal cost increase.

\section{Health Promotions}

Louisiana has been identified among those states with a high percentage of its population being overweight. This fact has lead to the formation of new coalitions to fight obesity and health groups. It would be beneficial to build on and support these efforts along with public health agencies and local groups which promote walking and bicycling. These physical activities have been shown to reduce the risk of diabetes, heart disease and other chronic diseases. It would make for a healthier city and could reduce costs to the health care system in the long run. 


\section{Types of Cyclists}

This section addresses the differing needs and priorities of different types and levels of ability of cyclists. The purpose of reviewing the needs of bicyclists is twofold: (a) it is instrumental when planning a system to serve different skill levels and different trip types; and (b) it is useful when attempting to quantify future usage and benefits to justify expenditures of resources. According to the US Department of Transportation, 57 million people, or almost 30 percent of the population 16 years or older rode a bicycle at least once during the summer of 2002. This large number of infrequent riders suggests that there is a large reservoir of potential bicyclists who do not ride (or ride more often). A major reason for this is because infrequent or non-riders do not feel comfortable using the existing street system and/or do not have appropriate bicycle facilities at their destination.

While the majority of Americans own bicycles, most of these people are recreational riders who ride relatively infrequently. School children between the ages of 6-14 typically make up a large percentage of bicycle riders, often riding to school, parks, or other local destinations. Adult road cyclists comprise a small, but enthusiastic, segment of regular bikeway users, along with serious off-road mountain bicyclists, who enjoy riding on trails and dirt roads.

There are three categories of cyclists that make up the large majority of the population. Each category requires a different level of support infrastructure and protection. Remembering each category is as easy as A-B-C:

Advanced - include long-distance road cyclists, racers, commuters and utilitarian cyclists; which is defined as those who use their bicycle as a primary means of transportation. These cyclists generally feel comfortable riding on roads and sharing the roads with automobile traffic. Rather than be directed to side streets, most cyclists making utilitarian trips would prefer to be given bike lanes or wider curb lanes on direct routes.

Basic - include youth and adults who are intermittent riders and may be nervous about riding in a street with cars, preferring quiet streets with less traffic and lower traveling speeds. These riders can be directed to side streets where traffic is less of an issue.

Children \& Senior Citizens - covers the youngest, oldest or least experienced of among us in the general population. Many of the trips made by this level are recreational; such as a family outing. With this in consideration, protection from hazards and grade separation are recommended wherever possible. Many younger children (ages seven to 11) use sidewalks for riding to schools or parks, which is acceptable in areas where pedestrian volumes are low and driveway visibility is high. Intersections along routes that are expected to contain these riders should have proper road markings and signaling. Sidewalk riding also increases conflicts with pedestrians. Children riding the wrong-way on-street are common, pointing to the need for safety education. 


\section{Existing Sidewalk and Bike Lane Inventory and Survey}

Transportation infrastructure can consist of existing streets, roadways, multi-use trails, rails, and bridges; these will be the main focus of this inventory. Other types of transportation infrastructure that will be considered in the larger scope of this project are parking, safety devices, signage, and crossings. Existing street networks provide the most direct route to and from desired locations and population centers. Suitability for pedestrian use will depend on factors such as the network continuity, safety provisions, and quality of sidewalks. The suitability for bicycle use will depend on roadway width, speed, and traffic flows.

Utilizing Google Earth's up-to-date aerial photographs and its easy user interface, a database was created of existing sidewalks and bike lanes and later verified by on the ground inspection. These files were subsequently all transferred to GIS for analysis. Every section of sidewalk and bike lane was labeled and categorized by city, street name, on which side of the street it was located, and if it was not contiguous, the segment number. Once the database of existing sidewalk and bike lane network was complete, sections of sidewalk that were missing were easy to identify. Were sidewalks did not exist; worn paths through vegetation were visible due to the high resolution of the photographs.

This method also allowed the ability to identify other potential opportunities for improvement. Intersections could be viewed and analyzed to see if they were sufficient for the existing and proposed pedestrian network. A few intersections were identified that are in need of treatments such as signage and stripping. It was also possible to roughly measure the width of roadways and their shoulders. This allowed the chance to preliminarily identify which roads were suitable for bicycle shared use or exclusive bike lanes. Multi-use trails, which can be created from either existing trail networks on private land or by abandoned railways, could also be identified.

\section{Pedestrian Facilities}

The ability for a pedestrian to make it safely from one destination to another depends on the continuity of the sidewalk network. When the concrete suddenly ends a pedestrian must make the decision of potentially getting dirty or walking in the street. Neither of these choices are desirable. The absence of sidewalks creates a sometimes insurmountable barrier for to people desire to walk in their neighborhood.

\section{Inventory}

Once we know where all of the sidewalks are, then we can tell where they are not. The City of Lake Charles has 881 individual segments of sidewalks totaling 323.5 miles. The area with the most complete sidewalk coverage is in the downtown area and in the numbered streets and boulevards between Broad Street and I-210. The areas that showed neighborhoods that were lacking in a complete sidewalk network were located north of I-10, south as well as east of I-210. The areas with the least sidewalk coverage were the areas located south of I-210 and west of Lake Street. Not only were the local roads in most of these areas without sidewalks, but the major roads in this area are also without any sort of bicycle or pedestrian support. Please refer to figure 7 on following page for map of existing sidewalks. 


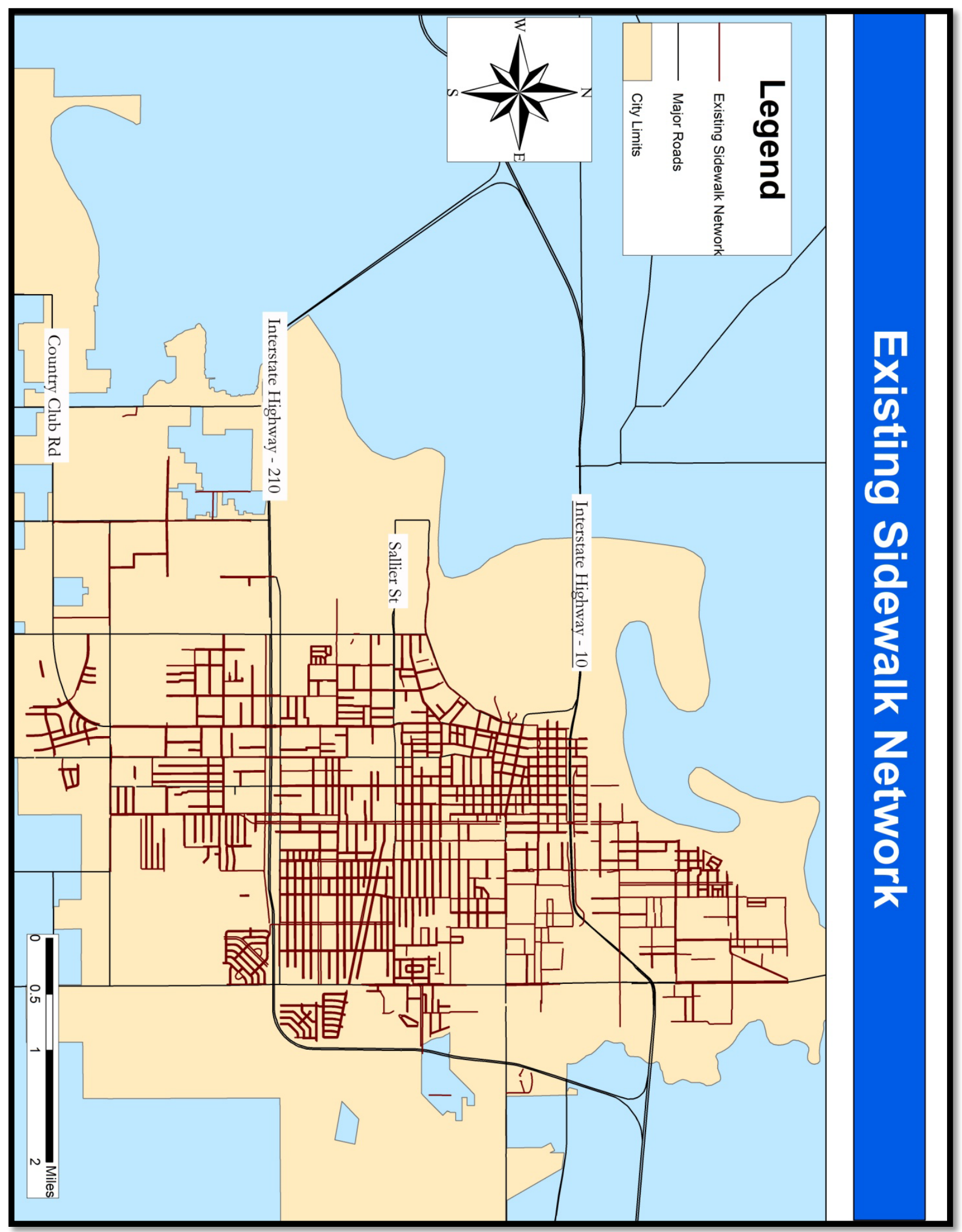




\section{Survey}

Obtaining a summary of existing infrastructure conditions is necessary in order to accurately gauge the ease and ability for pedestrians to move across the City of Lake Charles. This summary was produced by conducting a comprehensive survey of existing sidewalks located throughout the City. The goal of this survey is to find out information regarding the width of the sidewalk, the width of the buffer, the speed limit of the adjacent roadway, quality of the pavement, and quality of the landscaping on the sidewalk. All of these factors come together to present a picture of conditions that will help the Department of Public Works and the Department of Engineering decide which places are in most need of maintenance or repair.

\section{Sidewalk Width}

The width of a sidewalk is very important when considering location and pedestrian use density. While the national minimum standard for sidewalks used to be $4 \mathrm{ft}$., many cities today use $5 \mathrm{ft}$. as their minimum. This is because in order for people to comfortably pass each other, and not have to stop to let the other by, they need approximately five feet of sidewalk width. The table below shows recommended sidewalk widths depending on location.

Table 5: Recommended Sidewalk Widths

\begin{tabular}{|l|l|}
\hline Local or collector streets & $1.5 \mathrm{~m}(5 \mathrm{ft})$ \\
\hline Arterial or major streets & 1.8 to $2.4 \mathrm{~m}(6$ to $8 \mathrm{ft})$ \\
\hline CBD areas & 2.4 to $3.7 \mathrm{~m}(8$ to $12 \mathrm{ft})$ \\
\hline Along parks, schools, and other major generators & 2.4 to $3.0 \mathrm{~m}(8$ to $10 \mathrm{ft})$ \\
\hline
\end{tabular}

Most of the sidewalks, with a few exceptions, are 4 feet in width. Many sidewalks that are located near schools do not meet the national standard of 8 feet in width and may be inadequate to accommodate comfortable pedestrian travel. Sidewalks located in the CBD of Lake Charles are 8 feet wide and do meet the minimum standards set forth by the U.S. Dept. of Transportation.

\section{Sidewalk Buffer Width}

Buffers between sidewalks and roadways are important to provide a level of comfort, security, and safety to pedestrians. Landscaped buffers provide a space for poles, signs, and other obstructions, serve as places for storm-water infusion, and they protect pedestrians from splash. The table below showcases recommendations set forth by AASHTO for appropriate buffer widths.

Table 6: Recommended Buffer Widths

\begin{tabular}{|l|l|}
\hline Local or collector streets & 0.6 to $1.2 \mathrm{~m} \mathrm{(2} \mathrm{to} 4 \mathrm{ft})$ \\
\hline Arterial or major streets & 1.2 to $1.8 \mathrm{~m}(4$ to $6 \mathrm{ft})$ \\
\hline
\end{tabular}

The buffers located in the City of Lake Charles range from large and lush swaths of $13 \mathrm{ft}$. to non-existent buffers with sidewalks coming all the way the curb. This variation is a warning to planners and policy makers that the City should have a development ordinance that requires a designated buffer width for all new sidewalk construction. 


\section{Adjacent Roadway Speed Limit}

Motor vehicle traffic is the number one concern for pedestrian and bicycle safety when traveling adjacent to a roadway. The two biggest factors that affect motor vehicle traffic and safety are volume and speed. When a roadway is rarely traveled, the noise from traffic and likelihood of potential unwanted interactions between pedestrians and automobiles is minimal. As the number of vehicles increases so does the potential for accidents. These accidents and the resulting severity of injuries have a direct relationship to vehicular speed. Roadways with speed limits of $30 \mathrm{mph}$ or below are much more attractive to pedestrian and bicycle travel than streets with high rates of speed.

Speed limits of the adjacent roadways to sidewalks were observed in order to better judge which sidewalks are in need of safety treatments such as improved crossings, increased buffer widths, or street trees. These speed limits will also help in determining which roads are most appropriate for bicycle routes or bicycle lanes.

\section{Condition of Pavement}

Smooth and even sidewalks are not only visually inviting to pedestrians but also serve to allow people of all ability levels and transportation mode to traverse the city without worrying about tripping on cracks or running into obstacles. The condition of the pavement was ranked on a five point scale; with 5 being the new and 1 being completely degraded. Descriptions and pictures of the ranking system are showcased below.

5 - New Pavement: Newly constructed sidewalks that are smooth, bright, and have no cracks.

4 - Like New Pavement: Slightly older than new sidewalks. These sidewalks have little to no cracks, are smooth, and generally have a bright and attractive color.
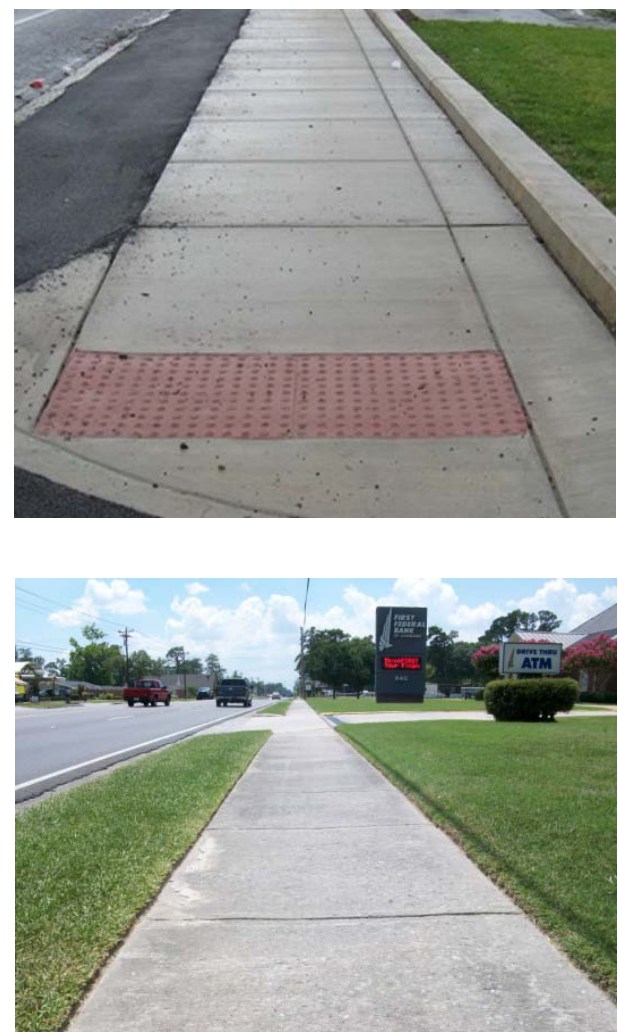
3 - Average Pavement: Some cracks are apparent, but the number is not numerous and the nature of them is not severe. The color of these sidewalks is dull and the overall surface will be rougher than those ranked 4.

2 - Below Average Pavement: Cracks are either prevalent in number or severe in nature. These sidewalks are generally uneven, difficult to traverse, and are need of repair. They might not allow for hard-wheeled modes of transportation such as skateboards, scooters, or roller skates.
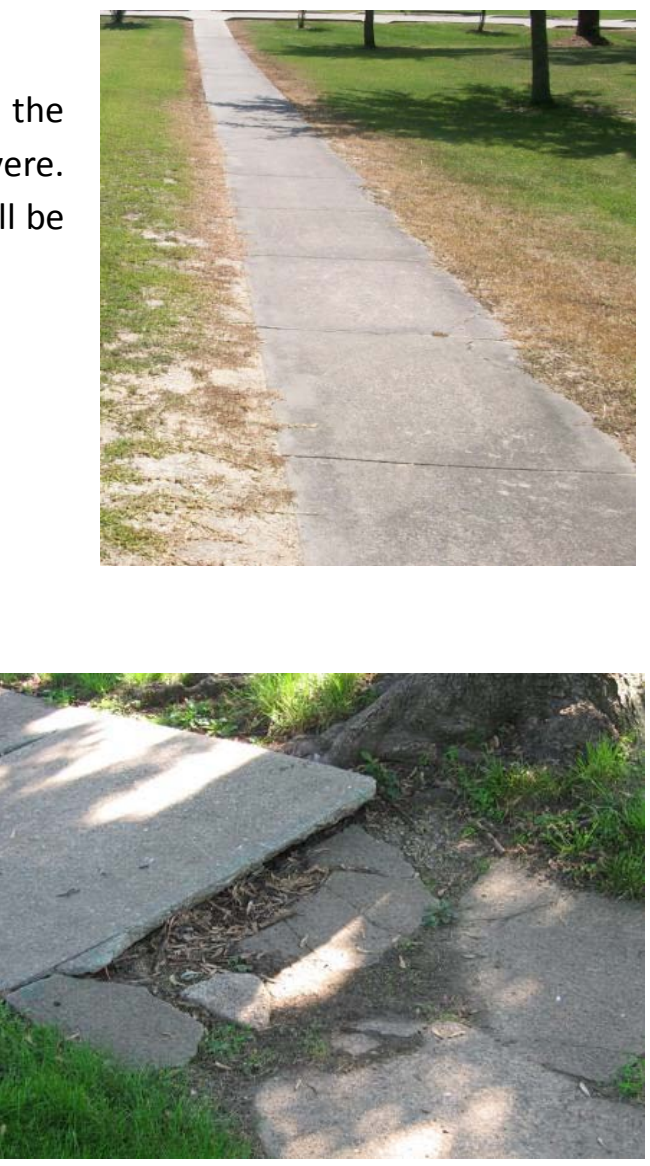

1 - Completely Degraded Pavement: No possibility of traversing this sidewalk. Severe cracks are prevalent throughout the sidewalk segment. These sidewalks are in need of immediate repair and cannot be considered when attempting to provide a network for sidewalk continuity.

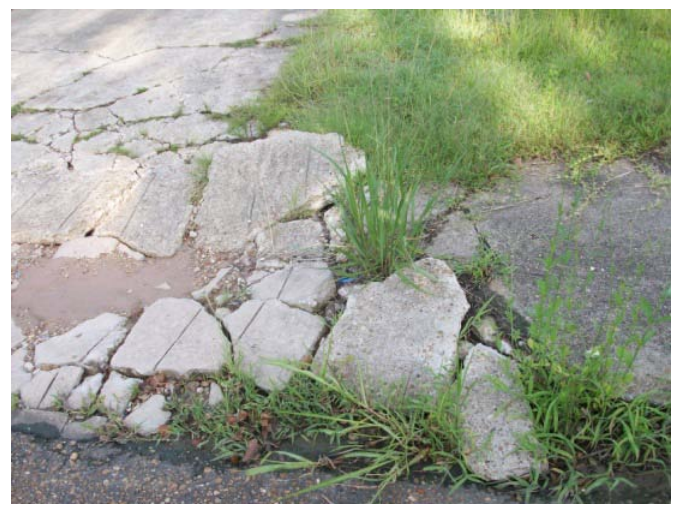




\section{Condition of Landscaping}

The quality and condition of landscaping is important for the aesthetic purposes and the ease of use for pedestrians. If grass or bushes are overgrown they can present barriers to people pushing a stroller or walking their dogs. Vegetation can block the path of sidewalks or create bumps in the sidewalk that are similar to cracks. Proper maintenance of sidewalk landscaping is imperative to give the impression of clean and tidy neighborhoods; where all modes of transportation can easily traverse through the city. The condition of the landscaping was ranked on a five point scale; with 5 being lined with bushes or trees and 1 being completely overgrown. Descriptions and pictures of the ranking system are showcased below.

5 - Bush or Tree-Lined Sidewalks: These sidewalks were planted with safety and aesthetics in mind. They are lined with bushes or trees that protect pedestrians from automobile traffic and provide beautiful scenery to observe.

4 - Clean and Edged Landscaping: These sidewalks are clear of obstructions and do not have any overgrown grass encroaching onto the sidewalk. No grass is growing in between the cracks and they are free of obstructions like bushes or tree limbs.

3 - Average Landscaping: While not perfect, these sidewalks are generally well maintained and are free of obstructions. Some overgrowth is prevalent, but for its entire length, and not to a point where it would affect a person's ability traverse the city.
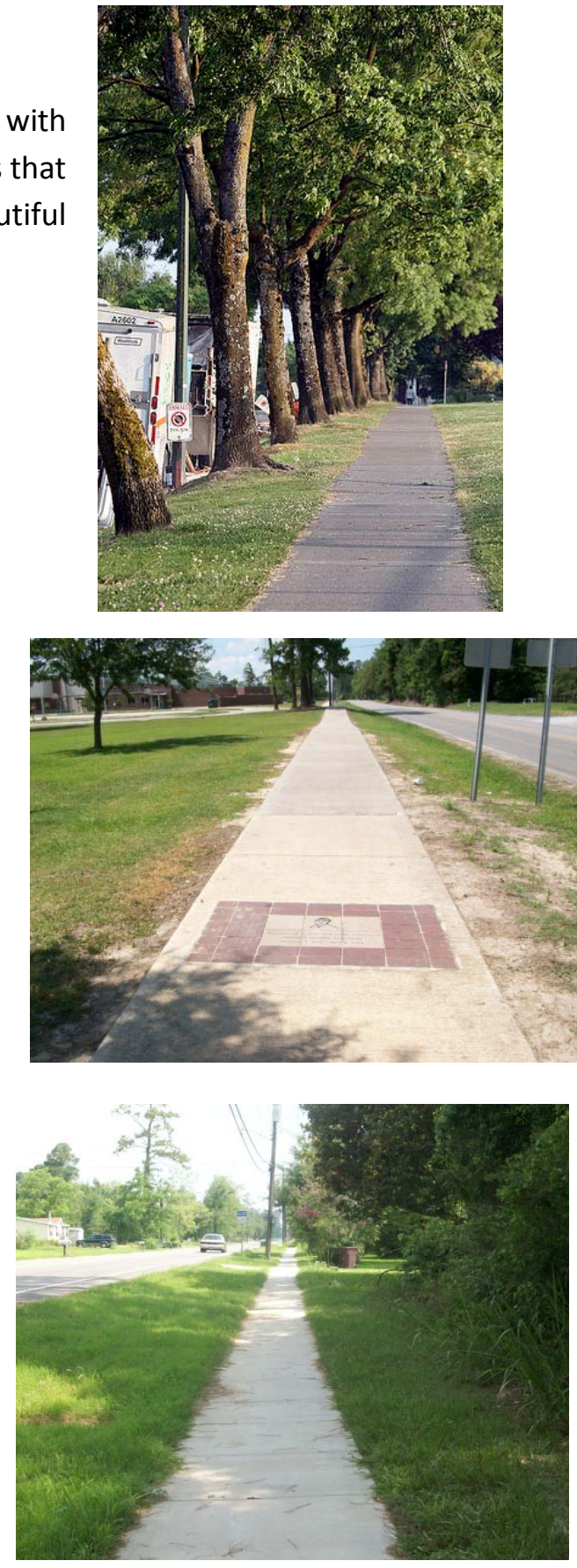
2 - Partly Overgrown or Obstructed Landscaping: This category pertains to sidewalks that have severe grass overgrowth in sections or are obstructed by either bushes or tree limbs. These sidewalks need maintenance immediately or they will continue to degrade to a point where they are unusable to pedestrian and other alternative modes of transportation.

1 - Completely Overgrown or Obstructed Landscaping: These sidewalks have been neglected to the point where they are completely covered with vegetation or are obstructed to a point where the sidewalk is no longer usable. These sidewalks are in immediate need of maintenance and they cannot be considered viable when attempting to provide a network for sidewalk continuity.

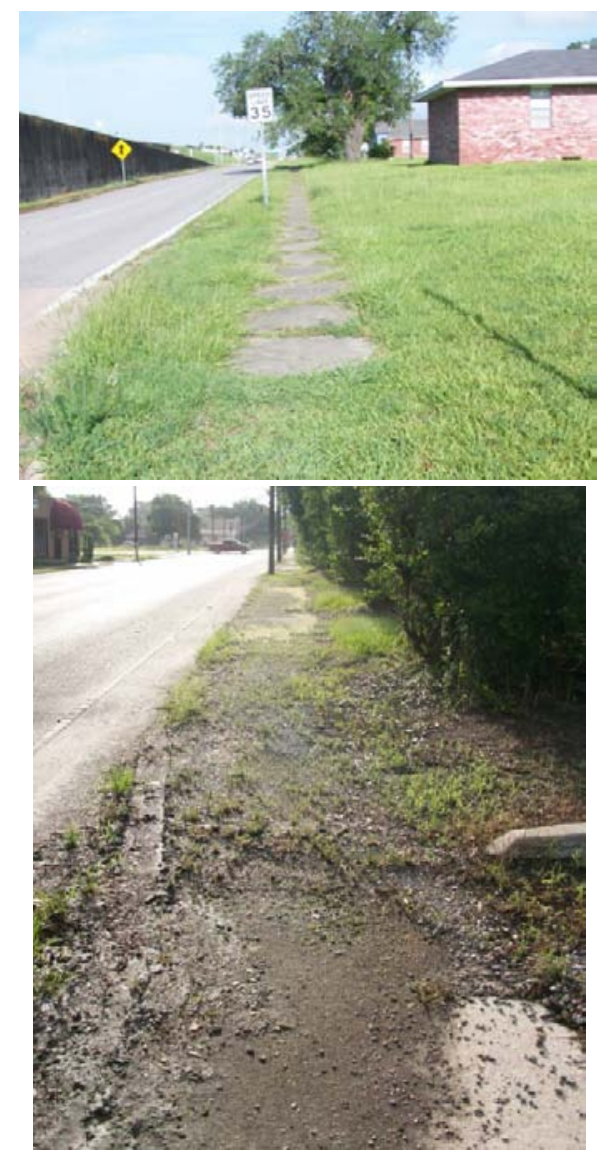

\section{Summary of Conditions}

\section{Width}

The average width of sidewalk in the City of Lake Charles is $4 \mathrm{ft}$. While the current national standard is $5 \mathrm{ft}$, many of the sidewalks built in the City were constructed during a time when $4 \mathrm{ft}$ was acceptable. The new sidewalks that were observed did comply with the $5 \mathrm{ft}$ standard. Sidewalks located around schools and parks were not noticeably wider than those of the surrounding area. The CBD area of the city did have sidewalks of $8 \mathrm{ft}$, but were sometimes obstructed by telephone poles.

\section{Buffer}

Many sidewalks in residential areas had large buffers that were well over the $6 \mathrm{ft}$ national standard. While many sidewalks located on local streets provided ample buffer width, the busier streets such as Ryan Street, Common Street, and those in the CBD had sidewalks that were placed all the way up to the roadway curb.

\section{Speed Limit}

Of the roadways observed with sidewalks, most of the speed limits were $25 \mathrm{mph}$. Only a few sidewalks were located on roadways with speed limits of $30 \mathrm{mph}$ or above. Low speed limits for automobiles on roadways make it attractive for pedestrians to traverse the city without worrying about safety. 


\section{Pavement}

On a 1-5 scale, with 1 being the worst and 5 being the best all existing sidewalks were surveyed for pavement condition. As could be expected, most of the sidewalks were ranked 3. A few sidewalks with the ranking of 5 were observed and none received the mark of 1 . The sidewalks that obtained the ranking of either 4 or 2 seemed to be clustered within the same area. This clustering suggests that the age of the neighborhood has a direct affect on the quality of pavement.

Table 7: Sidewalks In Need of Pavement Improvements

\begin{tabular}{|c|c|c|c|c|c|c|c|}
\hline $\begin{array}{l}\text { Sidewalk } \\
\text { Segment Name }\end{array}$ & Segment Extents & $\begin{array}{l}\text { Sidewalk } \\
\text { Width } \\
\text { (Feet) }\end{array}$ & $\begin{array}{l}\text { Buffer } \\
\text { Width } \\
\text { (Feet) }\end{array}$ & $\begin{array}{l}\text { Posted } \\
\text { Speed } \\
\text { Limit }\end{array}$ & $\begin{array}{l}\text { Pavement } \\
\text { Condition }\end{array}$ & $\begin{array}{l}\text { Landscaping } \\
\text { Condition }\end{array}$ & $\begin{array}{l}\text { Length } \\
\text { (Feet) }\end{array}$ \\
\hline Dietz St. East & 18th St to Penn St & 4 & 6 & 35 & 2 & 2 & 758 \\
\hline Alvin St. East & $\begin{array}{l}\text { South of Shell Beach Dr } \\
\text { to Ernest St }\end{array}$ & 4 & 6 & 25 & 2 & 3 & 2,366 \\
\hline $\begin{array}{l}\text { Channel St. } \\
\text { North }\end{array}$ & $\begin{array}{l}\text { N 1st Ave to } \mathrm{N} \\
\text { Shattuck St }\end{array}$ & 4 & 4 & 25 & 2 & 2 & 919 \\
\hline $\begin{array}{l}\text { Channel St. } \\
\text { South } 2\end{array}$ & $\begin{array}{l}\text { N Shattuck St to N } \\
\text { Prater St }\end{array}$ & 4 & 4 & 25 & 2 & 2 & 1,242 \\
\hline Dietz St. Wes & 18th St to Penn St & 4 & 6 & 35 & 2 & 2 & 755 \\
\hline East St. North & $\begin{array}{l}\text { Dr Michael Debakey Dr } \\
\text { to Common St }\end{array}$ & 5 & 6 & 25 & 2 & 2 & 2,341 \\
\hline $\begin{array}{l}\text { Gieffers St. } \\
\text { South }\end{array}$ & $\begin{array}{l}\text { N Enterprise Blvd to N } \\
\text { Shattuck St }\end{array}$ & 5 & 5 & 25 & 2 & 2 & 2,228 \\
\hline Griffith St. East & Park Ave to Wilson St & 4 & 7 & 25 & 2 & 4 & 358 \\
\hline $\begin{array}{l}\text { Louisiana Ave. } \\
\text { East } 2\end{array}$ & 18th St to Mitchell St & 4 & 2 & 25 & 2 & 3 & 4,343 \\
\hline $\begin{array}{l}\text { Louisiana Ave. } \\
\text { West } 2\end{array}$ & $\begin{array}{l}\text { Oak Park Blvd to E } \\
\text { McNeese St }\end{array}$ & 4 & 2 & 25 & 2 & 3 & 9,852 \\
\hline $\begin{array}{l}\text { Medora St } \\
\text { South } 3\end{array}$ & $\begin{array}{l}\text { End of road to } \mathrm{N} \\
\text { Booker St }\end{array}$ & 4 & 4 & 25 & 2 & 3 & 2,593 \\
\hline $\begin{array}{l}\text { N. MLK } \\
\text { Hwy/171 East }\end{array}$ & $\begin{array}{l}\text { Fitzenreiter Rd to } \\
\text { Moeling St }\end{array}$ & 6 & 0 & 40 & 2 & 2 & 5,311 \\
\hline $\begin{array}{l}\text { N. MLK } \\
\text { Hwy/171 West }\end{array}$ & $\begin{array}{l}\text { Fitzenreiter Rd to } \\
\text { Moeling St }\end{array}$ & 6 & 0 & 40 & 2 & 2 & 5,265 \\
\hline $\begin{array}{l}\text { Ryan St. West } \\
4\end{array}$ & $\begin{array}{l}\text { I-10 Onramp to Rail } \\
\text { Road Tracks }\end{array}$ & 5 & 0 & 35 & 2 & 3 & 354 \\
\hline $\begin{array}{l}\text { S. Railroad } \\
\text { Ave. South }\end{array}$ & $\begin{array}{l}\text { Hodges St to } \mathrm{N} \\
\text { Enterprise Blvd }\end{array}$ & 5 & 0 & 25 & 2 & 2 & 3,043 \\
\hline $\begin{array}{l}\text { W. Lawrence } \\
\text { St. North }\end{array}$ & Ann St to S Franklin St & 5 & 1 & 25 & 2 & 4 & 5,224 \\
\hline $\begin{array}{l}\text { Weincke St. } \\
\text { East }\end{array}$ & $\begin{array}{l}\text { Dr Michael Debakey Dr } \\
\text { to East St }\end{array}$ & 4 & 5 & 25 & 2 & 2 & 362 \\
\hline
\end{tabular}




\section{Landscaping}

On a 1-5 scale, with 1 being the worst and 5 being the best all existing sidewalks were surveyed for pavement condition. There were many neighborhoods throughout Lake Charles that had very well maintained landscaping on sidewalks and received a mark of 4 . On the other hand, the majority of homes seemed to look the other way when it came to edging and trimming of bushes and trees around their sidewalks and received the mark of 3. Grass growing in between cracks was common and the grass overgrowing sidewalks was a regular sight. The places that received a mark of 2 were mainly located around abandoned lots or in areas were development was sparse. Only a few places received a mark of 1 and were completely overgrown. No sidewalks were observed that provided street trees or bushes, therefore no sidewalk in the city received a mark of 5 for landscaping.

\begin{tabular}{|c|c|c|c|c|c|c|c|}
\hline $\begin{array}{c}\text { Sidewalk Segment } \\
\text { Name }\end{array}$ & Segment Extents & $\begin{array}{l}\text { Sidewalk } \\
\text { Width } \\
\text { (Feet) }\end{array}$ & $\begin{array}{l}\text { Buffer } \\
\text { Width } \\
\text { (Feet) }\end{array}$ & $\begin{array}{l}\text { Posted } \\
\text { Speed } \\
\text { Limit }\end{array}$ & $\begin{array}{l}\text { Pavement } \\
\text { Condition }\end{array}$ & $\begin{array}{l}\text { Landscaping } \\
\text { Condition }\end{array}$ & $\begin{array}{l}\text { Length } \\
\text { (Feet) }\end{array}$ \\
\hline Craft St South & $\begin{array}{l}\text { Louisiana Ave to Warren } \\
\text { Ave }\end{array}$ & 4 & 15 & 25 & 3 & 1 & 788 \\
\hline \multirow{5}{*}{$\begin{array}{l}\text { Dietz St East } \\
\text { Channel St North } \\
\text { Channel St South } 2 \\
\text { Dietz St West } \\
\text { East St North }\end{array}$} & 18th St to Penn St & 4 & 6 & 35 & 2 & 2 & 758 \\
\hline & N 1st Ave to N Shattuck St & 4 & 4 & 25 & 2 & 2 & 919 \\
\hline & N Shattuck St to N Prater St & 4 & 4 & 25 & 2 & 2 & 1,242 \\
\hline & 18th St to Penn St & 4 & 6 & 35 & 2 & 2 & 755 \\
\hline & $\begin{array}{l}\text { Dr Michael Debakey Dr to } \\
\text { Common St }\end{array}$ & 5 & 6 & 25 & 2 & 2 & 2,341 \\
\hline Gieffers St South & $\begin{array}{l}\text { N Enterprise Blvd to } \mathrm{N} \\
\text { Shattuck St }\end{array}$ & 5 & 5 & 25 & 2 & 2 & 2,228 \\
\hline $\begin{array}{l}\text { N MLK Hwy/ } 171 \\
\text { East }\end{array}$ & $\begin{array}{l}\text { Fitzenreiter Rd to Moeling } \\
\text { St }\end{array}$ & 6 & 0 & 40 & 2 & 2 & 5,311 \\
\hline $\begin{array}{l}\text { N MLK Hwy/ } 171 \\
\text { West }\end{array}$ & $\begin{array}{l}\text { Fitzenreiter Rd to Moeling } \\
\text { St }\end{array}$ & 6 & 0 & 40 & 2 & 2 & 5,265 \\
\hline $\begin{array}{l}\text { S Railroad Ave } \\
\text { South }\end{array}$ & $\begin{array}{l}\text { Hodges St to N Enterprise } \\
\text { Blvd }\end{array}$ & 5 & 0 & 25 & 2 & 2 & 3,043 \\
\hline Weincke St East & $\begin{array}{l}\text { Dr Michael Debakey Dr to } \\
\text { East St }\end{array}$ & 4 & 5 & 25 & 2 & 2 & 362 \\
\hline \multirow{2}{*}{$\begin{array}{l}\text { 1st Ave West } \\
\text { 2nd St South }\end{array}$} & Pujo St to 12 th St & 4 & 8 & 35 & 3 & 2 & 5,170 \\
\hline & $\begin{array}{l}\text { Louisiana Ave to Enterprise } \\
\text { Blvd }\end{array}$ & 4 & 4 & 25 & 3 & 2 & 322 \\
\hline \multirow{5}{*}{$\begin{array}{l}\text { 4th St South } \\
\text { Brooks St North } \\
\text { Carl St West } \\
\text { Cessford St North } \\
\text { Cessford St South }\end{array}$} & Enterprise Blvd to 1st Ave & 4 & 6 & 25 & 3 & 2 & 799 \\
\hline & N Booker St to Pear St & 4 & 2 & 25 & 3 & 2 & 987 \\
\hline & See St to Katherine St & 4 & 3 & 25 & 3 & 2 & 681 \\
\hline & N Lincoln St to N Malcolm St & 4 & 2 & 25 & 3 & 2 & 1,921 \\
\hline & N Prater St to N Booker St & 4 & 0 & 25 & 3 & 2 & 1,328 \\
\hline \multirow{3}{*}{$\begin{array}{l}\text { Church St North } \\
\text { Church St North } 2 \\
\text { Craft St North }\end{array}$} & Ryan St to Hodges St & 5 & 5 & 25 & 3 & 2 & 813 \\
\hline & Moss St to Ford St & 5 & 5 & 25 & 3 & 2 & 420 \\
\hline & $\begin{array}{l}\text { Louisiana Ave to Warren } \\
\text { Ave }\end{array}$ & 4 & 15 & 25 & 3 & 2 & 802 \\
\hline E School St North 2 & $\begin{array}{l}\text { Common St to Louisiana } \\
\text { Ave }\end{array}$ & 4 & 7 & 25 & 3 & 2 & 2,619 \\
\hline E School St South 2 & Common St to Louisiana & 4 & 7 & 25 & 3 & 2 & 2,620 \\
\hline
\end{tabular}




\begin{tabular}{|c|c|c|c|c|c|c|c|}
\hline \multirow{4}{*}{$\begin{array}{l}\text { Ford St East } \\
\text { Ford St West } \\
\text { Foster St East }\end{array}$} & \multicolumn{7}{|l|}{ Ave } \\
\hline & S Railroad Ave to Church St & 4 & 4 & 25 & 3 & 2 & 500 \\
\hline & S Railroad Ave to Church St & 4 & 4 & 25 & 3 & 2 & 495 \\
\hline & $\begin{array}{l}\text { Shellbeach Dr to Dr Michael } \\
\text { Debakey Dr }\end{array}$ & 4 & 8 & 25 & 3 & 2 & 1,093 \\
\hline Foster St East 2 & $\begin{array}{l}\text { Dr Michael Debakey Dr to } \\
\text { Woodruff St }\end{array}$ & 4 & 8 & 25 & 3 & 2 & 717 \\
\hline \multirow{4}{*}{$\begin{array}{l}\text { Graham St East } \\
\text { I-10 Srv Rd North } \\
\text { I-10 Srv Rd North } 2 \\
\text { Leaman St North }\end{array}$} & Mary St to Fizenreiter Rd & 4 & 2 & 25 & 3 & 2 & 2,409 \\
\hline & Haskell St to Church St & 4 & 4 & 35 & 3 & 2 & 3,145 \\
\hline & 1st Ave to Albert St & 4 & 4 & 35 & 3 & 2 & 4,116 \\
\hline & $\begin{array}{l}\text { Louisiana Ave to Warren } \\
\text { Ave }\end{array}$ & 4 & 8 & 25 & 3 & 2 & 767 \\
\hline Legion St North 4 & $\begin{array}{l}\text { Gerstner Memorial Dr to } \\
\text { Siebarth Dr }\end{array}$ & 4 & 4 & 40 & 3 & 2 & 3,196 \\
\hline Legion St South 3 & $\begin{array}{l}\text { Gerstner Memorial Dr to } \\
\text { Siebarth Dr }\end{array}$ & 4 & 4 & 40 & 3 & 2 & 2,851 \\
\hline $\begin{array}{l}\text { Louisiana Ave East } \\
3\end{array}$ & Oregon St to E McNeese & 4 & 2 & 25 & 3 & 2 & 5,986 \\
\hline N 1st Ave West & Moeling St to Fournet St & 5 & 5 & 35 & 3 & 2 & 3,208 \\
\hline N 1st Ave East 2 & N Channel St to End of Road & 4 & 2 & 35 & 3 & 2 & 369 \\
\hline $\begin{array}{l}\text { N Enterprise Blvd } \\
\text { West }\end{array}$ & Gieffers St to empty lot & 5 & 5 & 35 & 3 & 2 & 1,473 \\
\hline N Kirkman St West & $\begin{array}{l}\text { Opelousas St to N Railroad } \\
\text { Ave }\end{array}$ & 5 & 0 & 25 & 3 & 2 & 1,298 \\
\hline Pine St North & $\begin{array}{l}\text { Louisiana Ave to Enterprise } \\
\text { Blvd }\end{array}$ & 4 & 5 & 25 & 3 & 2 & 363 \\
\hline S Lyons St East & Mill St to Broad St & 4 & 3 & 25 & 3 & 2 & 1,477 \\
\hline S Lyons St West & Mill St to Broad St & 4 & 3 & 25 & 3 & 2 & 1,479 \\
\hline $\begin{array}{l}\text { W Lawrence St } \\
\text { South }\end{array}$ & Ann St to S Franklin St & 5 & 1 & 25 & 3 & 2 & 5,174 \\
\hline Warren Ave West & 18th St to E Prien Lake Rd & 4 & 12 & 25 & 3 & 2 & 2,938 \\
\hline $\begin{array}{l}\text { Woodring St South } \\
2\end{array}$ & $\begin{array}{l}\text { N. Shattuck Dr to N Goos } \\
\text { Blvd }\end{array}$ & 4 & 8 & 25 & 3 & 2 & 570 \\
\hline Broad St North 4 & East of S Lyons St to 8th Ave & 5 & 0 & 35 & 4 & 2 & 4,499 \\
\hline Evans St South & Prater St to Albert St & 4 & 0 & 25 & 4 & 2 & 1,284 \\
\hline Griffith St West & Park Ave to Wilson St & 5 & 7 & 25 & 4 & 2 & 365 \\
\hline Hagan St North & N Lincoln St to Graham St & 4 & 1 & 25 & 4 & 2 & 616 \\
\hline Helen St South & Lake St to Westwood St & 4 & 10 & 25 & 4 & 2 & 1,609 \\
\hline
\end{tabular}




\section{Bicycle Facilities}

\section{Bicycle Routes}

The City of Lake Charles currently has a bicycle route system comprised of 10 roadway segments. They were chosen because of their proximity to schools and parks. The location of the network is mostly located around the downtown area, but does also reach south down to I-210.

According to AASHTO, shared lanes should be located on roads with vehicle volumes of under 10,000 per day and travel speeds of $30 \mathrm{mph}$ or less. Following these standards, six out of the ten of the current bicycle network roadways are not appropriate to be classified as bicycle routes. The high roadway traffic volumes or travel speeds mean that only the most advanced riders should attempt riding on streets such as Shell Beach Dr or Lake St. The route designed previously by the city was well thought out and most of the roads in the current bicycle route network are included in the new recommendations for a bikeway network, although improvements are suggested; such as additions of bicycle lanes and corresponding roadway redesign or widening. Refer to table 9 for a list of improvements needed to the existing bicycle route network.

Table 9: Existing Bicycle Route Network

\begin{tabular}{|c|c|c|c|c|c|c|c|}
\hline Road Name & Segment & $\begin{array}{l}\text { Avg. Daily } \\
\text { Volume }\end{array}$ & $\begin{array}{l}\text { Speed } \\
\text { Limit }\end{array}$ & $\begin{array}{l}\text { Existing } \\
\text { Travel } \\
\text { Lane }\end{array}$ & $\begin{array}{l}\text { New } \\
\text { Travel } \\
\text { Lane } \\
\end{array}$ & $\begin{array}{l}\text { New } \\
\text { Classification }\end{array}$ & $\begin{array}{l}\text { Improvem } \\
\text { ents } \\
\text { Needed }\end{array}$ \\
\hline \multirow{2}{*}{$\begin{array}{l}\text { Shell Beach } \\
\text { Dr. } \\
\text { W Mill St }\end{array}$} & $\begin{array}{l}\text { Clarence St. to } \\
\text { Lake St. }\end{array}$ & Above 10000 & 45 & 11 & 12 & Bike Lane & $\begin{array}{l}\text { Road } \\
\text { Widening }\end{array}$ \\
\hline & $\begin{array}{l}\text { Veterans } \\
\text { Memorial Dr to } \\
\text { Goos St }\end{array}$ & Under 3000 & 25 & 11 & 11 & Shared Lane & Signage \\
\hline E Mill St & $\begin{array}{l}\text { Goos St to Hwy } \\
171\end{array}$ & Under 3000 & 25 & 15 & 15 & Shared Lane & Signage \\
\hline $\begin{array}{l}\text { N. Kirkman } \\
\text { St }\end{array}$ & $\begin{array}{l}\text { N Railroad Ave to } \\
\text { I-10 Svc Rd }\end{array}$ & Under 3000 & 25 & 12 & 12 & Shared Lane & Signage \\
\hline Kirkman St. & $\begin{array}{l}\text { N. Railroad Ave } \\
\text { to College St }\end{array}$ & $\begin{array}{l}\text { Between } 3,000 \\
\text { and } 10,000\end{array}$ & 35 & 16 & 11 & Bike Lane & $\begin{array}{l}\text { Stripping \& } \\
\text { Signage }\end{array}$ \\
\hline $\begin{array}{l}\text { Kirkman St. } \\
2\end{array}$ & $\begin{array}{l}\text { College St to E } \\
\text { McNeese St }\end{array}$ & $\begin{array}{l}\text { Between } 3,000 \\
\text { and } 10,000\end{array}$ & 35 & 12 & 12 & Bike Lane & $\begin{array}{l}\text { Road } \\
\text { Widening }\end{array}$ \\
\hline Lake St. & $\begin{array}{l}\text { Shell Beach Dr. to } \\
\text { Country Club Rd. }\end{array}$ & Above 15,000 & 35 & 12 & 12 & Bike Lane & $\begin{array}{l}\text { Road } \\
\text { Widening }\end{array}$ \\
\hline Jackson St & $\begin{array}{l}\text { N. Ryan St to } \\
\text { Kirkman St }\end{array}$ & Under 3000 & 25 & 12 & 12 & Eliminate & Eliminate \\
\hline $\begin{array}{l}\text { South } \\
\text { Shattuck }\end{array}$ & $\begin{array}{l}\text { Broad St. to } \\
\text { Opelousas St. }\end{array}$ & $\begin{array}{l}\text { Between } 3,000 \\
\text { and } 10,000\end{array}$ & 35 & 16 & 11 & Bike Lane & $\begin{array}{l}\text { Stripping \& } \\
\text { Signage }\end{array}$ \\
\hline Broad St & $\begin{array}{l}\text { S. Shattuck St to } \\
\text { 2nd Ave }\end{array}$ & Above 15,000 & 35 & 10 & 12 & Eliminate & Eliminate \\
\hline
\end{tabular}




\section{Bicycle Lanes}

There are no official bike lanes within the city limits of Lake Charles, though there is one south of the city on Gauthier Rd. This bike lane is $6 \mathrm{ft}$ wide and runs east-west for 2.75 miles. While the length and width of this bike lane is impressive, there are no other bike lanes or bike routes connecting to this segment. This could serve as a vital and much used east-west connection for the southern portion of Lake Charles if connections to a supporting bicycle network were made.

\section{Regional Connections with Existing Shoulder Available}

There are a few state highways running through Calcasieu Parish that have shoulders that are at least 4 feet wide, which is the minimum adequate space for a bike rider. While these roadway shoulders are not marked for bicyclists specifically, they do provide sufficient space for advanced and, in some cases, basic skill-level riders. These existing roadways can be used to build connections between communities in the Lake Charles Metropolitan Area. Table 10 and Figure 8 on the following page showcase available regional connections.

Table 10: Existing Regional Bicycle Network with Shoulder Available for Bicycles

\begin{tabular}{|c|c|c|c|}
\hline Location & $\begin{array}{c}\text { Street or } \\
\text { Highway Name }\end{array}$ & Extents & $\begin{array}{l}\text { Length } \\
\text { (Miles) }\end{array}$ \\
\hline Dequincy to Sulphur & Hwy. 27 & Barney Hoffpauir Rd to Orchard St & 14.3 \\
\hline Sulphur to Westlake & Hwy 90 & Creek crossing to Picard Rd & 1.0 \\
\hline Sulphur to Westlake & Hwy $90-2$ & Prater Rd to Trousdale Rd & 5.3 \\
\hline Westlake to Moss Bluff & Hwy 378 & River Mist to Park Rd & 1.6 \\
\hline Moss Bluff to Topsy & Hwy 171 & Hwy 378 to Topsy Rd & 5.0 \\
\hline Moss Bluff to Lake Charles & Hwy 171 & Conoco St to Walmart & 0.3 \\
\hline Lake Charles to lowa & Hwy $90-3$ & Hwy 171 to Bridge w/o shoulder & 1.3 \\
\hline Lake Charles to lowa & Hwy 90 - 4 & Bunker Rd to State Route 397 & 2.3 \\
\hline South Lake Charles & State Route 397 & Gerstner Memorial Dr to Fruge St & 5.1 \\
\hline
\end{tabular}


Figure 8: Existing Regional Bikeway Network

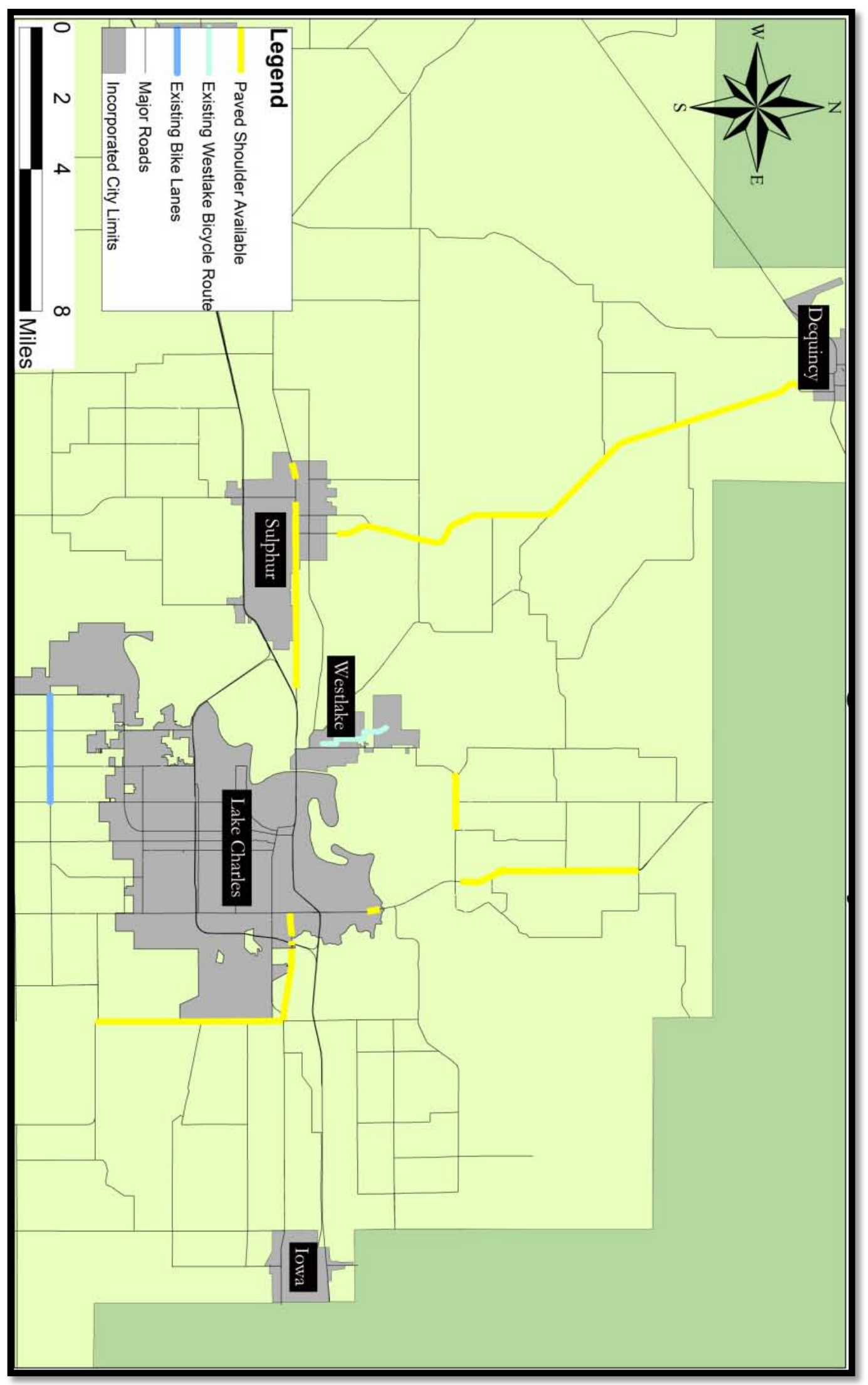




\section{Current or Ongoing Bicycle or Pedestrian Support Expansion Projects}

\section{Lakefront Promenade and Multi-Use Path}

Figure 9:Lakefront Promenade

The civic center lakefront is in the process of a major redesign, including a harbor, mixed-use development, and improvements to pedestrian accessibility. A much heralded and anticipated promenade and multi-use path has already been completed. Running along Bord Du Lac, this promenade features elaborate inlays and tastefully designed lighting schemes. If the new I-10 bridge includes a pedestrian bridge as well, then this lakefront path could eventually serve to bridge the gap between recreational riders and functional

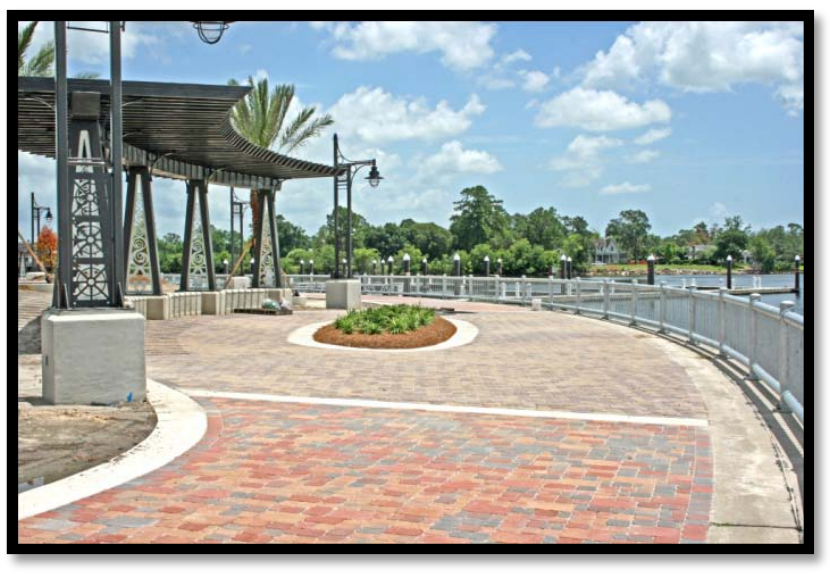
commutes from one part of the city to another.

\section{Corbina Roadway Extension and Multi-Use Path}

Set to begin construction soon and be completed by the end of 2011, the Corbina Rd. expansion project will extend the roadway from its current terminus at Highway 14 all the way to E. Prien Lake Rd. The roadway is planned to be 60 feet wide with four travel lanes and eight foot wide paved shoulders. The project is also slated to incorporate a 10 foot wide, two-way, bike path on one side of the road, separated from automobile traffic by an open ditch buffer. The multi-use path will run 2.75 miles and is designed to accommodate various types of non-motorized users such as pedestrians and other wheeled modes. This path will serve as the first true bike/multi-use path in all of Calcasieu Parish. When completed, this project will also serve as an important north/south spine for a new network of nonmotorized support infrastructure.

\section{Gulf Highway Expansion}

The Gulf Hwy expansion project could have been a great opportunity to extend pedestrian and bicycle access to portions of Southern Lake Charles and Calcasieu Parish. Unfortunately, the cost, logistics, and narrow right of way made the feasibility of including sidewalks or bike lanes not possible.

\section{$1^{\text {st }}$ Ave Multi-Use Path}

Still in its preliminary planning stages, this path is expected to be approximately $10-12 \mathrm{ft}$ wide multi-use path that run from the railroad tracks north of $\mathrm{I}-10$ to $12^{\text {th }}$ St. Broken up into two phases the northern section would run from the railroad tracks north of I-10 to Broad St; the southern section would run from Broad St to the $12^{\text {th }} \mathrm{St}$. The southern section has a $50 \mathrm{ft}$ wide median that could serve as ample room for a path. 


\section{Chapter 4: Goals and Policy Recommendations}

The Louisiana Bicycle and Pedestrian Master Plan recommends that each municipality or jurisdiction prepare, adopt, and implement a comprehensive bicycle and pedestrian plan. Through the statement and adoptions of these goals and policy recommendations the City of Lake Charles Bicycle and Pedestrian Master Plan places a greater emphasis on planning for bicycles and pedestrians in the ongoing work of shaping streets and managing traffic.

The characteristics that make up a pedestrian and bicycle friendly environment have been grouped into five main categories: connectivity, travelway character, context character, education, and safety. Each one is described below, followed by a set of goals and related policy recommendations that can be used in conjunction with subsequent action items to implement the goals.

\section{Connectivity}

Connectivity refers to the bikeway, pedestrian, and transit network. A well-connected network of streets and pedestrian ways means that it is easy for bikes and pedestrians to get around. Connectivity includes support for safe, convenient street crossings. Walking and transit go hand in hand - transit riders typically supplement their trip with some form of pedestrian travel at both ends.

\section{Connectivity Goals}

$>$ Goal 1: Develop a cohesive non-motorized network of sidewalks, bikeways, and street crossings that make alternative transportation a realistic way to get around.

$>$ Goal 2: Provide a continuous bicycle and pedestrian network that connects sites within blocks, and connects buildings to each other, to streets, and to transit facilities.

$>$ Goal 3: Provide crossings that are convenient and comfortable for pedestrians and bicyclists to use.

\section{Connectivity Policies for Consideration}

- New developments should connect to neighboring developments.

- Commercial areas should create a vehicular and/or pedestrian connection to adjacent residential communities and provide a future connection option for future developments.

- New residential communities should connect to existing residential and commercial developments, as well as provide connection possibilities to future adjacent developments.

- Provide direct connections or shortcuts from residential areas to neighborhood commercial destinations, parks, gathering places, and trails, especially in new or infill development by connecting dead-end streets or cul-de-sacs to adjacent streets or trails.

- Provide connections over barriers such as railroads, waterways, and freeways.

- Reduce, eliminate, or provide access around obstructions, such as utility poles, that are barriers to non-motorized travel. 


\section{Travelway Character}

Travelway character refers to the roadway space between travel lanes and curbs as well as sidewalk space. Roadway space can be designed to serve traffic while still providing a high-quality bicycle and pedestrian environment. The design of the sidewalks and bike lanes and the elements within it are key parts of creating a bicycle and pedestrian-friendly environment. This requires more than just minimum width requirements. Sidewalks are multi-functional, and their design should reflect the need to provide walking space as well as accommodating small children riding their bikes.

\section{Travelway Character Goals}

$>$ Goal 4: Create a street design sensitive to its context.

$>$ Goal 5: Design sidewalks that are enjoyable to walk along and that acknowledge their multifunctional purposes.

$>$ Goal 6: Preserve the health of the natural environment, improve air and water quality and reduce energy consumption by increasing the rates of walking and bicycling.

\section{Travelway Character Policies for Consideration}

- Provide landscaped sidewalk buffers and urban design features, especially in areas of high pedestrian activity, in order to encourage walking.

- Improve the street-level experience for pedestrians, by promoting the inclusion of landscaping and street trees to provide shade and enhance streetscape appearance.

- Encourage wider sidewalks in areas with high levels of pedestrian activity. The width of a sidewalk should be proportional to the demand for pedestrian activity.

\section{Context Character}

Context Character refers to the way the adjacent land-uses interact with the pedestrian or bicyclist. A pedestrian friendly environment should have a positive relationship to an area's land use.

\section{Context Character Goals}

$>$ Goal 7: Provide adequate bicycle parking at desired locations.

$>$ Goal 8: Design buildings such that their architecture enhances and encourages pedestrian activities.

$>$ Goal 9: Provide pedestrian friendly automobile parking layouts to prevent isolating pedestrians from their destinations.

\section{Context Character Policies for Consideration}

- Require bicycle parking rack standards for commercial developments.

- Provide clear, direct, and attractive internal pedestrian networks that connect buildings, neighborhoods, and commercial centers to the adjacent sidewalk.

- New commercial development should be oriented to the pedestrian and include pedestrian walkways. 


\section{Education}

Part of the success of making a place where walking a bicycling are commonplace will come from educating walkers, bikers, and automobile drivers about state and local laws. The goals for education should seek to inform citizens of the City about creating a role for walking and bicycling to contribute positively into the social cohesion of the community.

\section{Education Goals}

$>$ Goal 10: Promote pedestrian and bicyclist awareness in the City of Lake Charles such that it becomes the commonplace.

$>$ Goal 11: Coordinate with other transportation agencies to develop a more seamless multimodal transportation system.

\section{Education Policies for Consideration}

- Provide at least one event annually that promotes pedestrian and bicycle safety such as "Walk to School Day."

- Develop partnerships with local schools, driving clubs, and biking or walking organizations to develop educational materials and promote bicycling and pedestrian awareness.

- Promote safe and courteous walking, biking, and driving through targeted outreach programs.

\section{Safety}

Safety goals address the need to create safe, visible, and convenient bikeway and sidewalk conditions. Factors such roadway crossings, internal site circulation, seamless access to transit, and truly multimodal streets go into account for the quality of safety for both pedestrians and cyclists.

\section{Safety Goals}

$>$ Goal 12: Increase the safety of the walking and bicycling environment and reduce injuries and fatalities by providing a high level of care and consideration for these modes.

$>$ Goal 13: Develop and implement speed management policies that support safe driving speeds on all City roads.

\section{Safety Policies for Consideration}

- All new sidewalks shall provide buffering from auto traffic and off-street parking lots, and provide trees that will shade sidewalks.

- Consider special treatments such as pedestrian refuge islands, countdown signals, and others as described in Appendix C: Design Guidelines.

- Explore opportunities to eliminate lanes and reduce roadway widths where appropriate in order to accommodate bicycle traffic. Lane elimination strategies are typically called "road diets" and are effective at improving multimodal travel conditions and managing vehicle speeds. 


\section{Chapter 5: Methodology for Prioritizing Projects}

The methodology utilized for identifying highest priority improvements included the following steps:

1. Identify all street segments lacking sidewalks

2. Rank all segments based on four factors: Generator Score, Attractor Score, Connectivity, and Affordability \& Ease

3. Identify clusters of the highest-scoring street segments to develop candidate project areas

4. Rank the top projects based on a weighted average of improvement need for all street segments in candidate project areas

As mentioned in "Chapter 3: Existing Conditions," a survey was conducted in which the existing pedestrian and bicycle networks were identified. Four factors were considered when prioritizing improvements to address gaps in the pedestrian or bicycling network. These four factors are:

1. Generator Score - This score is related to the propensity of a particular area to generate pedestrians or bicyclists. Census Block Groups (CBGs) ranked on criteria that would preclude the assumption for pedestrians or bicyclists to be present. Criteria include presence of persons under 16 years of age and household income. Scores were placed on a 1 (worst) to 9 (best) scale.

2. Attractor Score - The attractor score is related to the propensity of a particular destination to be attractive for pedestrians or bicyclists. Some places are more likely to for people to walk or bike to than to drive. Examples of these destinations include schools, civic buildings, and parks. Each attractor was given a value and then an approximately $1 / 4$ mile was placed around it. The areas with the highest amount of attractors had the highest value scores. Scores were placed on a 1 (worst) to 10 (best) scale. This category has an added weighted factor of 2.

3. Connectivity - Number of existing sidewalks or bike lanes the project would connect to. This is important in order to promote sidewalk continuity. There is no added weighted factor added to this category.

4. Affordability and Ease - Some projects are bound to be more costly and difficult to implement than others. This category is to try and identify the "lowest handing fruit" of potential projects. The estimated cost of the project based the factors of cost of materials and construction, filling in of ditches, and overcoming barriers such as bridges. Set on a scale of 1 (worst) to 5 (best). This category has an added weighted factor of 2 .

These four categories are explained in greater detail on the following page. 


\section{Generators}

Certain population segments are likely to produce people with higher propensities to bicycle or walk. While certain segments of the population might have the ability to drive to their destination, others do not have access to an automobile. These people must be supported by pedestrian infrastructure from their home all the way to their destination. Four spatial categories were considered by Census Block Group to determine a generator score.

1. Population Density - Census Block Groups with a higher density of residences are more likely to have a need for pedestrian support as more people will be demanding facilities. In order to classify those areas with the highest population density, Census 2000 data and existing GIS data was be utilized. Population density was then multiplied with following two other categories to obtain values.

\section{Percentage of Households with Persons Under the Age of 16 - Other than public} transportation, walking and biking are usually the only modes of transportation available to children. Children under the age of 16 are not old enough to operate a motor vehicle and the elderly might have health problems that keep them from driving safely. Furthermore, many children do not have the maturity to safely navigate a street network that was designed and built exclusively for automobile travel. Residential density values were effectively calculated using the existing Calcasieu Parish GIS database by block group. This density was multiplied by the percentage of households with persons under the age of 16 to receive a score. The scores were divided into ten categories and given a corresponding value from 1 to 10 .

\section{Percentage of Households with Persons Over the Age of 60 - Persons over the age of 60} are less likely to drive automobiles and are more likely to be mobility-impaired. Mobility-impaired residents require greater accessibility measures, especially within their immediate residential neighbor hoods. Residential density values were effectively calculated using the existing Calcasieu Parish GIS database by block group. This density was multiplied by the percentage of households with persons over the age of 60 to receive a score. The scores were divided into ten categories and given a corresponding value from 1 to 10 .

4. Household Income - Lower income families are much more likely to rely on walking and public transportation for their travel needs, and also require greater accessibility measures within their neighborhoods. People in low income households are nearly twice as likely to walk as people in other income groups (Murakami and Young, 1997). Some residents may be dependent on these modes for travel to work and for achieving financial independence. The median household income in each (CBG) was listed and ranked according to area median household income (AMI). The lowest earning households will receive the highest values of pedestrian generation. Those CBGs that had a household income below poverty level (less than $80 \%$ of $\mathrm{AMI}$ ) were given a score of 3 , those CBGs with household income above poverty level but below AMI were given a score of 2, and the CBGs with household income above AMI were given a score of 1 . 
Figure 10: Pedestrian Attractor Map

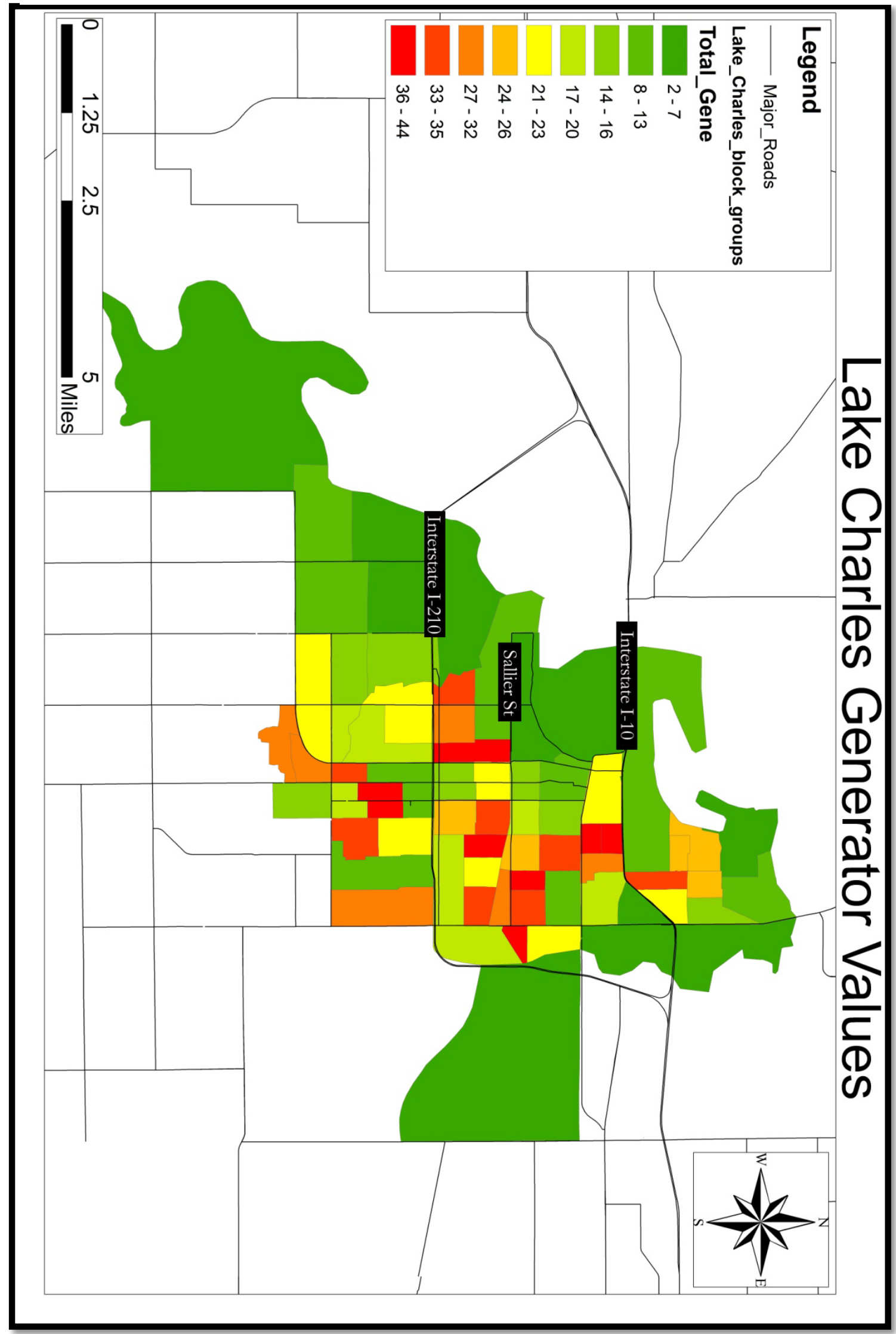




\section{Attractors}

The reason people travel is to get to a destination. Certain destinations are more likely than others to attract people who would walk or bike. 11 categories of attractors have been selected and a brief description of why they were chosen is given. Each category has a corresponding value associated with it that ranks its propensity to attract bicycle or pedestrian travel; schools and public transit stops were ranked the highest. A "buffer" of $1 / 4$ mile, which is standard in walkability, was placed around each of the attractors. See table 1 below for a list of attractors and their corresponding value. An additional weighting of 2 was multiplied to the values.

\section{Schools}

Many students walk or ride bicycles on the sidewalks to school. Students, particularly younger children, are among the most vulnerable pedestrians. Areas around schools, where student pedestrians congregate, require special attention in the form of pedestrian facilities and safety measures.

\section{Parks}

Parks attract recreational users of all ages. Pedestrian access and safety facilities are essential to park accessibility.

\section{Recreation and Halls}

These are buildings such as a community centers, pools, or VFW halls. These places are destinations for children and the elderly.

\section{Libraries}

The places of learning are top destinations for all age groups. Many low-income and senior individuals use the library for internet access.

\section{Recreational Facilities}

These were community baseball, soccer, and football fields. Children use these often and games can be big draws for people of all ages.

\section{Civic Buildings}

Access to public buildings is a critical component to the ADA Title II. Administrative buildings, court houses and other public buildings provide a wide-range of services to children, senior adults, and mobility-impaired residents.

\section{Hospitals}

People recovering from illness or injury often have to get exercise to stimulate healing. Family members also like to take a walk during times of distress. Offering sidewalks or trails around a hospital is important to promote safe walking. 


\section{Police Stations}

Many people are given tickets, such as DUIs and must go to the police station to resolve them or conduct community service. Also repeat offenders are less likely to own an automobile and are prone needing access to alternative modes of transportation.

\section{Post Office}

These civic buildings are used by all segments of the adult population. Access from all modes of transportation should be promoted around these buildings.

\section{Stadiums}

These are destinations for large events for people of all ages and parking and traffic tends to be a problem. Providing sidewalks and bike lanes would ease congestion and allow people without cars to have access to these events.

\section{Fire Stations}

These are usually located around places with residential development. While not many people would need to walk or bike to these destinations, the proximity to housing makes them a popular spot for new sidewalk construction.

Table 10: Attractor Value Matrix

\begin{tabular}{lc}
\hline \multicolumn{1}{c}{ Attractor } & Score \\
\hline Schools & 5 \\
Parks & 4 \\
Recreation \& Halls & 4 \\
Libraries & 4 \\
Recreational Facilities & 4 \\
Civic Buildings & 3 \\
Hospitals & 3 \\
Police Stations & 2 \\
Post Office & 2 \\
Stadiums & 2 \\
Fire Stations & 1 \\
\hline
\end{tabular}


Figure 11: Lake Charles Attractor Locations

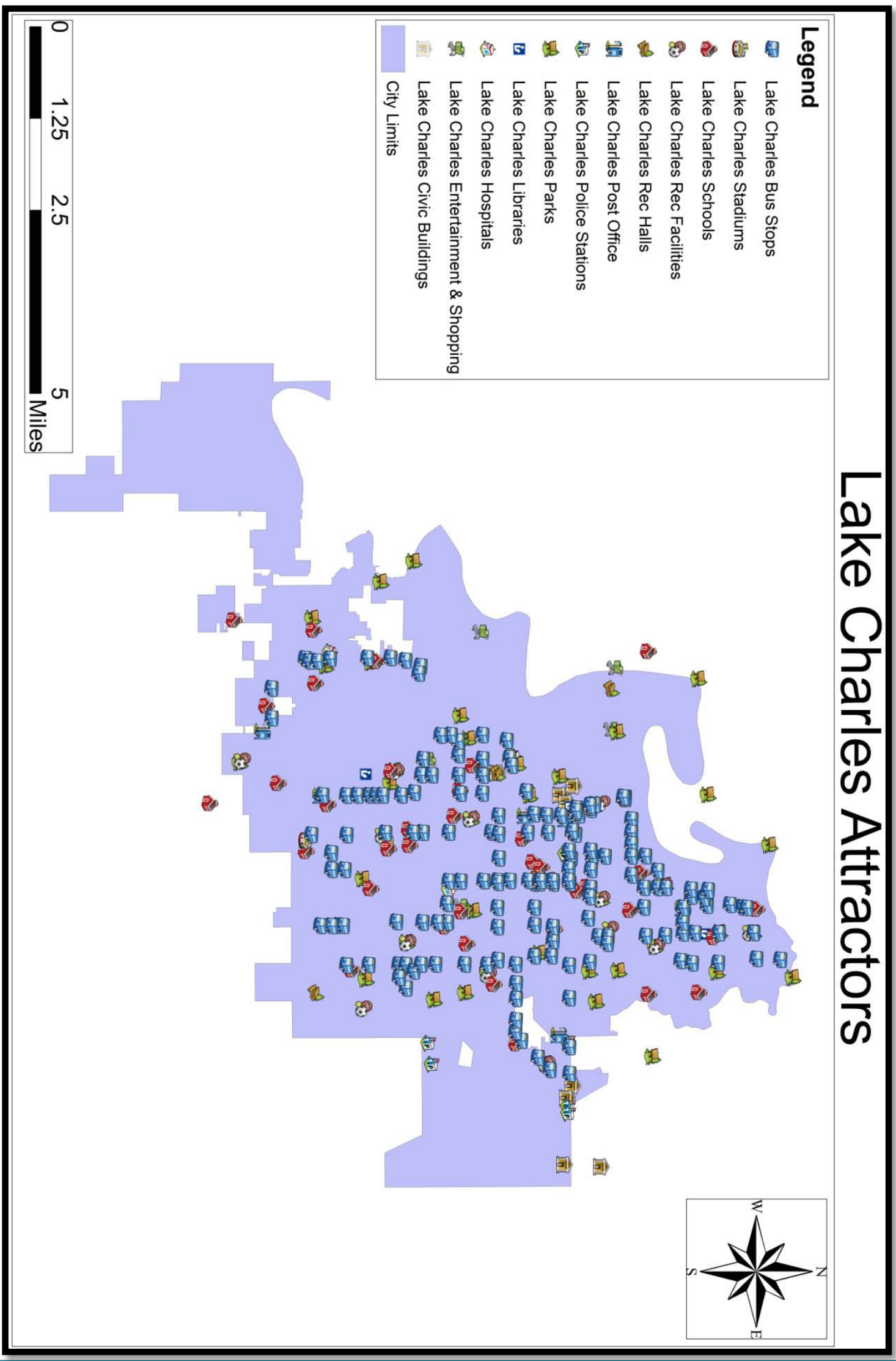


Figure 12: City of Lake Charles Attractor Map

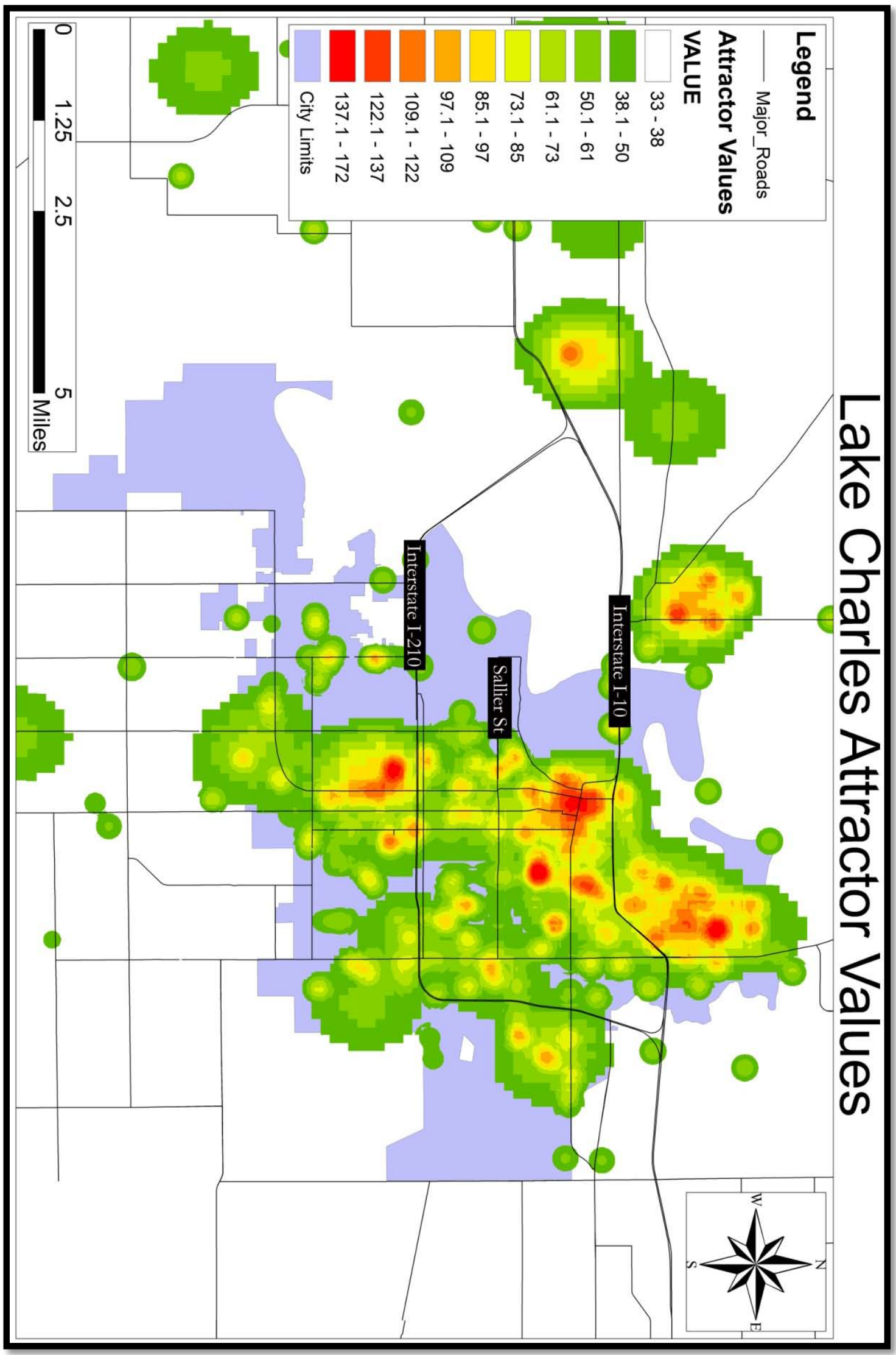




\section{Connectivity}

Figure 13: Sidewalk Ending Abruptly

The connectivity score is important to promote sidewalk and bikeway continuity. Interruptions may require pedestrians to cross a busy arterial street midblock or a bike to have to travel a busy road while unprotected from traffic. The idea is to allow pedestrians and bicyclist the chance to get from the origin all the way to their destination safely.

For every existing sidewalk the proposed project would connect to, the project will receive a point. There is no limit on the amount of points a proposed sidewalk can receive for connectivity.

\section{Affordability}

\section{Pedestrian Infrastructure Improvements}

Sidewalk construction costs can be defined in on a general basis, a cost per square foot basis. While this helps to estimate the cost of a project, things such constructing new curbs \& gutters or filling in of open ditches can raise the cost significantly. In light of this, all recommended sidewalk projects were reviewed for current conditions and were notated if they were located on roadways without curb \& gutter or had open ditches on their flanks. Figure $\mathrm{x}$ below shows which sidewalk projects might require the construction of curb \& gutter, the filling in of ditches, or both. 


\section{Bicycle Infrastructure Improvements}

While some roads have sufficient width to accommodate bike lanes, many roads in Lake Charles are not suitable for those facilities at this time due narrow lane widths, high traffic volumes or speeds. If the City wishes to make these roads safer and more comfortable for cyclists a total redesign may be necessary to reduce the number of lanes, implement traffic calming measures, or widen the road sufficiently to provide adequate width to separate bicyclists from vehicle traffic.

Because governmental agencies work within a defined budget, costs are always an important factor to consider when choosing which projects to fund. To take this into account, the costs of each project have been estimated by considering certain factors which can affect the overall price. Examples of factors that are considered are cost of construction, filling in of existing ditches, and overcoming barriers such as bridges. Each project was ranked on a 1 (highest price) to 5 (lowest price) scale. In the final calculation this category has an added weighted factor of 2 .

The following construction cost assumptions are generalized and are based on national averages. They do not take into account for right of way acquisition, administration costs, or local labor costs.

\section{Highest Cost: Roadway widening, building bridges, and/or covering ditches.}

Redesigning the road will require a high level of preparation, including engineering analysis, design, and public involvement. In order to meet LADOTD standards, additional treatments may be necessary, such as installing a median or controlling driveway access. Construction costs could be high, due to new bridge construction or if open ditches flank the road and must be covered. Depending on these factors the general construction cost could cost between $\$ 800,000$ to over $\$ 1,000,000$ per mile.

\section{High Cost: Roadway widening and reconstructing sidewalks.}

Some roadways have sidewalks or parking lots built right up to the roadway. If the roadway is to widened, all development flanking the proposed expansion will have to be reconstructed. The cost for these projects range between $\$ 400,000$ to $\$ 800,000$ per mile.

\section{Moderate Cost: Widening roadway to provide sufficient width for bicycle lane.}

This may require major redesign. In addition, costs may increase if it is determined there is a need for drainage improvements prior to widening. Sometimes these projects can be conducted as part of routine resurfacing. Cost range for these projects range between $\$ 200,000$ to $\$ 400,000$ per mile.

\section{Low Cost: Roadway redesign with signage and stripping of a bicycle lane.}

Minor roadway/lane redesign may be required, but should be minimal. Most of the cost comes from planning and logistics with materials cost being very low, (e.g., less than $\$ 10,000$ per linear mile for thermoplastic striping). Construction costs are much less than those for shoulder widening; between $\$ 50,000$ to $\$ 100,000$ per mile. May be included as part of a routine resurfacing. 


\section{Lowest Cost: Installing bicycle route signage.}

Costs will include some design to determine signage locations, installation, and sign costs. Most signs are approximately $\$ 150$ and installation costs approximately $\$ 100$, for a total of $\$ 250$ per sign. Costs are generally under $\$ 10,000$ per mile.

Table 2: Affordability Index

\begin{tabular}{|l|l|r|}
\hline \multicolumn{3}{|c|}{ Sidewalk Affordability Index } \\
\hline Cost Estimate Range (Total Cost) & Cost Category & Cost Score \\
\hline Under 20k & Very Low & 5 \\
\hline Between 20-50k & Low & 4 \\
\hline Between 50-100k & Moderate & 3 \\
\hline Between 100-150k & High & 2 \\
\hline Above 150k & Very High & 1 \\
\hline
\end{tabular}

\begin{tabular}{|l|l|r|}
\hline \multicolumn{3}{|c|}{ Bikeway Affordability Index } \\
\hline Cost Estimate Range (Per Mile) & Cost Category & Cost Score \\
\hline Under 50k & Very Low & 5 \\
\hline Between 50k-100k & Low & 4 \\
\hline Between 200k to 400k & Moderate & 3 \\
\hline Between 400k to 800k & High & 2 \\
\hline 800k to over 1 million & Very High & 1 \\
\hline
\end{tabular}




\section{Chapter 6: Recommended Route Network}

The City of Portland, Oregon recently conducted a study regarding the levels of walking in areas around the city. The study found that the provision of sidewalks could be used as an indicator for the likelihood of pedestrian activity. It is almost certain that a city that designs it roadways to accommodate bicycles and pedestrians will have higher levels of non-motorized transportation than a city that is designed solely for automobiles. This fact gives credence to the famous adage from the movie Field of Dreams, "If you build it, they will come."

Recommended improvement projects were identified by using three steps: aerial analysis, fieldwork surveys, and stakeholder input meetings. Projects include the filling in of gaps in the existing infrastructure network or new project areas identified as categories of concern. Projects are ranked by the four factors discussed in chapter 5; generator, attractor, connectivity, and affordability scores.

While all projects have been ranked, ranking does not dictate the recommended order of construction or programming schedule. The programming schedule should take place on a year to year basis and should focus on projects that are related to the connectivity or completion of an area-wide system, fixes to safety concerns, and availability of funding. It is recommended that programming be a planning/public/political experience where all sides get a say in what areas are of the most concern to them.

The recommendations and definitions in this chapter are intended to identify facilities that can be applied to the Lake Charles Metro Area to better accommodate non-motorized transportation modes. Bicycle facilities share roadways with automobiles, whereas pedestrian facilities and trails/paths often require grade separation from automobile traffic. In order to cover all of the specifics associated with various types of support systems, this chapter is split into three sections Pedestrian Facilities, Bikeway Network, and Trails/Paths. 


\section{Pedestrian Facilities}

Sidewalks serve as the backbone of the non-motorized transportation network. They need to be placed close to the origin (homes) of users and continue uninterrupted to their likely destination (school, job, etc.). The ability for a pedestrian to make it safely from one destination to another depends on the continuity of the sidewalk network.

When the concrete suddenly ends a pedestrian must make the decision of walking in the mud or walking in the street. Neither of these choices are desirable. Even worse, someone with disability has no choice at all. The absence of sidewalks creates a sometimes insurmountable barrier for to people desire to walk in their neighborhood. Sidewalk accessibility and continuity should be held in high esteem.

The City of Lake Charles has many gaps in its existing sidewalk network, 147 new sidewalk segments were recommended. This list of recommended new projects is not exhaustive, it includes gaps in existing networks, and also suggests new sidewalks on major roads, but does not get into recommending sidewalks in existing neighborhoods without any existing sidewalk network. The recommended solution is to work with Calcasieu Parish to have a "sphere of influence" clause in the development code that requires new residential or commercial developments to include sidewalks.

The recommended new projects list was broken up into four locations/areas throughout the City; North Lake Charles, Central Lake Charles, South-Central Lake Charles, and South Lake Charles. While some of the projects run through more than one location, they are only represented once on each area map. 


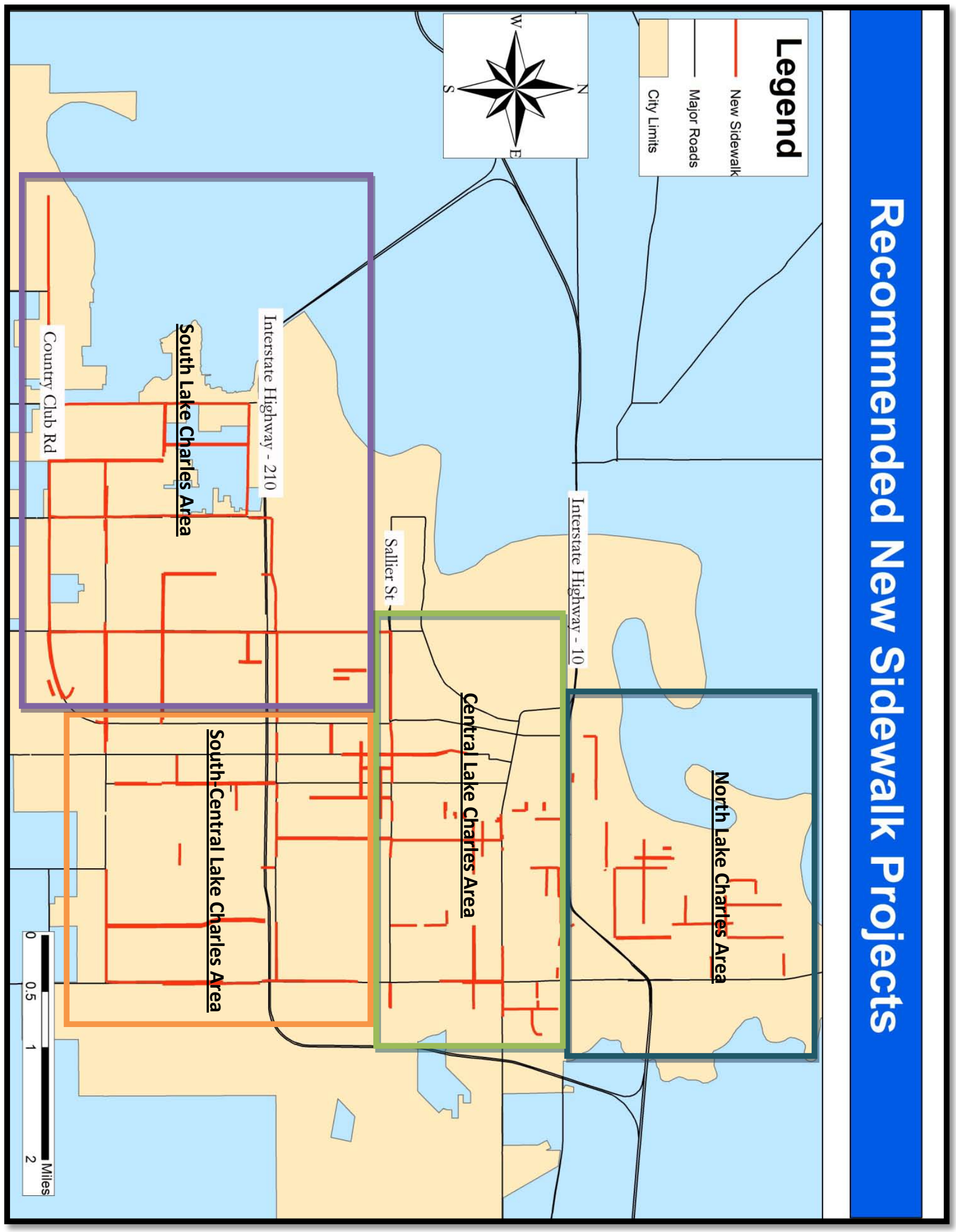




\section{North Lake Charles}

This area of the City is very residential in nature. Some of the highest ranking projects are located here. It has numerous schools and community recreational facilities. Overall, it has a household income range on the lower end of the area median income (AMI), which could mean that many of its residents are without the use of a car and bicycle or walking may be their primary form of transportation. The sparse and non-contiguous nature of the sidewalk network in this area makes it a prime candidate for sidewalk expansion projects.

Table 3: North Lake Charles Recommended Sidewalks

\begin{tabular}{rlllr}
\hline $\begin{array}{r}\text { Map } \\
\text { Ref\# }\end{array}$ & \multicolumn{1}{c}{ Sidewalk Name } & \multicolumn{1}{c}{ Segment Extents } & \multicolumn{1}{c}{$\begin{array}{c}\text { Priority } \\
\text { Range }\end{array}$} & $\begin{array}{r}\text { Length } \\
\text { (Feet) }\end{array}$ \\
\hline 1 & Fitzenreiter Rd South & N Lincoln St to Hwy 171 & Moderate & 1,049 \\
3 & N. Simmons St. East 2 & Medora St. to Fitzenreiter Rd. & High & 2,650 \\
4 & Courtney St. South & Medora St. to Fitzenreiter Rd. & High & 2,652 \\
5 & N. Goos Blvd. East & Courtney St to Existing Sidewalk & Moderate & 633 \\
6 & N. Booker St. East & Moeling St. to Knapp St. & Moderate & 1,288 \\
7 & Medora St. North & N. Prater St. to N. Booker St. & High & 2,800 \\
8 & Medora St. South & N Booker St to N Simmons St & High & 1,295 \\
9 & Woodring St North & N Booker St to N Simmons St & High & 605 \\
10 & Woodring St South & N Booker St to N Simmons St & High & 595 \\
11 & Griffin St South & N MLK Hwy to Sally Mae St & High & 595 \\
12 & Katherine St South & N Prater St to N Booker St & High & 1,030 \\
13 & N. Lyon St. West & Commercial St. to Moeling St. & Moderate & 4,317 \\
14 & N. Lyon St. East & Commercial St. to Moeling St. & Moderate & 410 \\
15 & N. Blake St. West & Moeling St. to Geiffers St. & High & 404 \\
16 & N. Blake St. East & Moeling St. to Geiffers St. & High & 1,745 \\
17 & N. Shattuck St. East & Moeling St. to Opelousas St. & High & 2,895 \\
18 & N. Simmons St. West & Moeling St. to Opelousas St. & High & 2,607 \\
19 & N. Simmons St. East & Moeling St. to Opelousas St. & High & 2,610 \\
20 & Cessford St. North & N. Prater St. to N. 1st ave. & High & 3,977 \\
21 & Opelousas St. South & N. Shattuck St. to N. Simmons St. & High & 3,288 \\
22 & Fournet St North & N Enterprise Blvd to N Shattuck St & Moderate & 2,137 \\
23 & Connecting Pedestrian Path & N. Shattuck to Fournet St. & High & 83 \\
24 & Jackson St South & N Bank St to N Ryan St & Moderate & 2,991 \\
25 & N. Ryan St East & S Railroad Ave to Jackson St & High & 594 \\
26 & Church St. North & Ford St to Kirkman St & Moderate & 429 \\
\hline
\end{tabular}


Figure 15: North Lake Charles Recommended Sidewalks

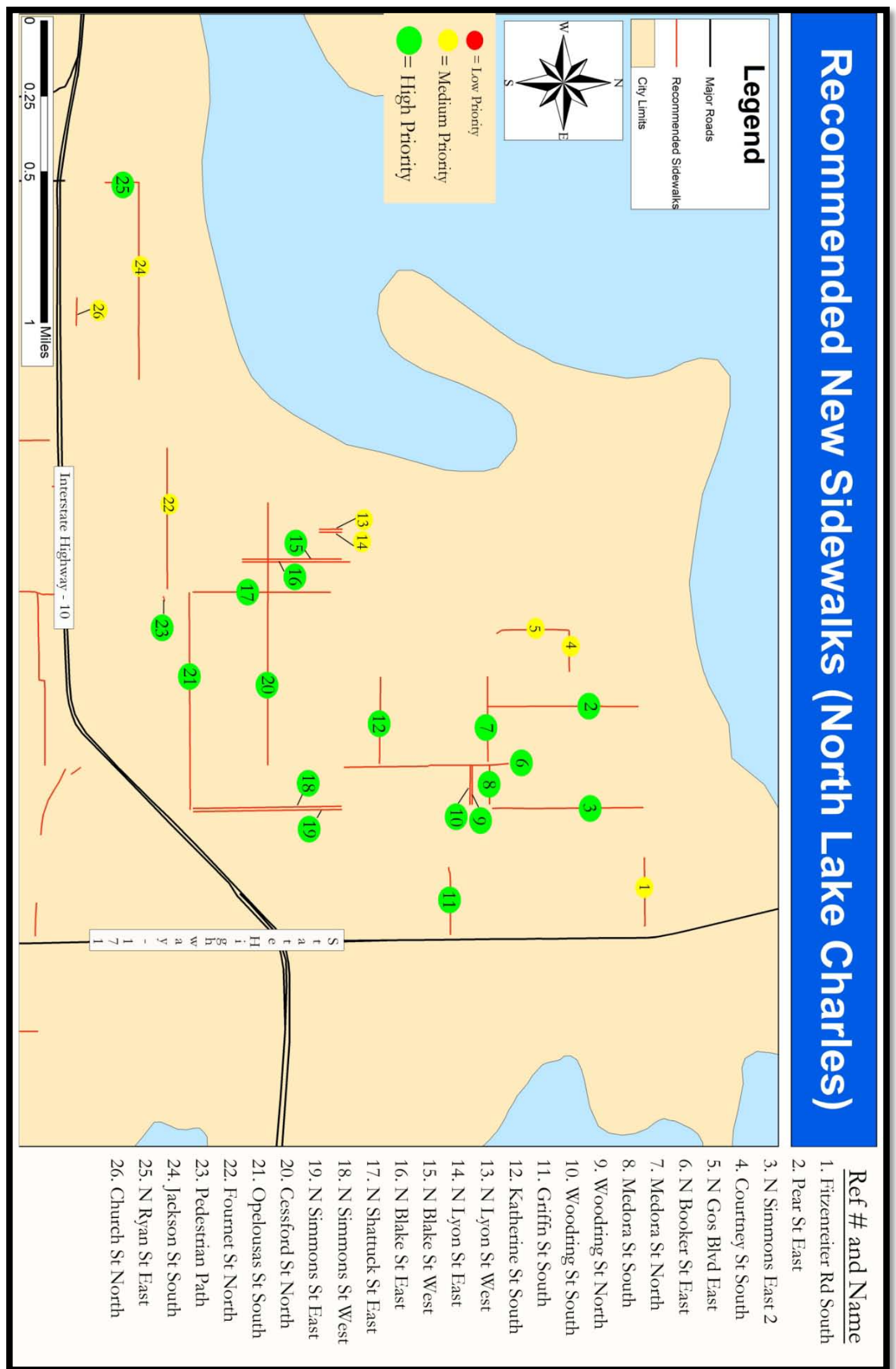


The following table is intended to be used as a quick reference for each suggested segment of the recommended sidewalk network.

\begin{tabular}{|rc|}
\hline $\begin{array}{r}\text { (map reference \#) Street Name: Segment } \\
\text { Recommended } \\
\text { Sidewalk Width }\end{array}$ & $\begin{array}{r}\text { Range between five to } \\
\text { eight feet }\end{array}$ \\
\hline $\begin{array}{r}\text { Recommended } \\
\text { Buffer Width: }\end{array}$ & $\begin{array}{c}\text { Range between two to six } \\
\text { feet }\end{array}$ \\
\hline $\begin{array}{r}\text { Priority Index } \\
\text { Ranking: }\end{array}$ & $\begin{array}{c}\text { Ranking based upon scores } \\
\text { derived from attractor and } \\
\text { generator scores, } \\
\text { connectivity, and } \\
\text { affordability added } \\
\text { together }\end{array}$ \\
& \\
\hline
\end{tabular}

\section{Reason Selected}

Discusses the importance and need for the project

Cost

Estimates costs for recommended facility type.

Funding Source

Identifies potential sources for funding the recommended improvements. 


\section{North Lake Charles Area}

\begin{tabular}{|cc|}
\hline (map ref \# 1) Fitzenreiter Rd South: N Lincoln St to Hwy 171 \\
\hline Recommended Sidewalk Width & 5 feet \\
\hline Recommended Buffer Width: & $2-4$ feet \\
\hline Priority Index Ranking: & 89 (Moderate) \\
\hline
\end{tabular}

Reason Selected: Will connect with other sidewalks, within 1/4 mile to school

Cost: $\$ 26,234$

Funding Source: Safe Routes to School, General Fund

\begin{tabular}{|cc|}
\hline (map ref \# 2) Pear St East: Medora St to Fitzenreiter Rd \\
\hline Recommended Sidewalk Width & 5 feet \\
\hline Recommended Buffer Width: & $2-4$ feet \\
\hline Priority Index Ranking: & 21 (High) \\
\hline
\end{tabular}

Reason Selected: Located within 1/4 mile to a school, will connect to other sidewalks

Cost: $\$ 66,261$

Funding Source: Safe Routes to School, General Fund

\begin{tabular}{|cc|}
\hline (map ref \# 3) N Simmons St East 2: Medora St to Fitzenreiter Rd \\
\hline Recommended Sidewalk Width & 5 feet \\
\hline Recommended Buffer Width: & $2-4$ feet \\
\hline Priority Index Ranking: & 4 (High) \\
\hline
\end{tabular}

Reason Selected: Located next to a community center and within 1/4 mile a school

Cost: $\$ 66,306$

Funding Source: Safe Routes to School, General Fund

\begin{tabular}{|cc|}
\hline \multicolumn{2}{|c|}{ (map ref \# 4) Courtney St South: N Goos Blvd to N Prater St } \\
\hline Recommended Sidewalk Width & 5 feet \\
\hline Recommended Buffer Width: & $2-4$ feet \\
\hline Priority Index Ranking: & 95 (Moderate) \\
\hline
\end{tabular}

Reason Selected: Connects parts of existing network

Cost: $\$ 15,814$

Funding Source: General Fund

\begin{tabular}{|cc|}
\hline (map ref \# 5) N Goos Blvd East: Courney St to Existing Sidewalk \\
\hline Recommended Sidewalk Width & 5 feet \\
\hline Recommended Buffer Width: & $2-4$ feet \\
\hline Priority Index Ranking: & 95 (Moderate) \\
\hline
\end{tabular}

Reason Selected: Extends a current sidewalk and to connect to existing network

Cost: $\$ 32,198$

Funding Source: General Fund 


\begin{tabular}{|cc|}
\hline (map ref \# 6) N Booker St East: Moeling St to Knapp St \\
\hline Recommended Sidewalk Width & 5 feet \\
\hline Recommended Buffer Width: & $2-4$ feet \\
\hline Priority Index Ranking: & 15 (High) \\
\hline
\end{tabular}

Reason Selected: Fills gap in existing sidewalk network

Cost: $\$ 70,000$

Funding Source: General Fund

\begin{tabular}{|cc|}
\hline (map ref \# 7) Medora St North: N Prater St to N Booker St \\
\hline Recommended Sidewalk Width & 5 feet \\
\hline Recommended Buffer Width: & $2-4$ feet \\
\hline Priority Index Ranking: & 9 (High) \\
\hline
\end{tabular}

Reason Selected:Located within 1/4 mile a school and connects two vital parts of existing network

Cost: $\$ 32,371$

Funding Source: General Fund, Safe Routes to School

\begin{tabular}{|cc|}
\hline (map ref \# 8) Medora St South: $N$ Booker St to $n$ Simmons St \\
\hline Recommended Sidewalk Width & 5 feet \\
\hline Recommended Buffer Width: & $2-4$ feet \\
\hline Priority Index Ranking: & 2 (High) \\
\hline
\end{tabular}

Reason Selected: Located within 1/4 mile a school and connects two vital parts of existing network

Cost: $\$ 15,137$

Funding Source: General Fund, Safe Routes to School

\begin{tabular}{|cc|}
\hline (map ref \# 9) Woodring St North: N Booker St to N Simmons St \\
\hline Recommended Sidewalk Width & 5 feet \\
\hline Recommended Buffer Width: & $2-4$ feet \\
\hline Priority Index Ranking: & 6 (High) \\
\hline
\end{tabular}

Reason Selected: Will connect parts of existing network

Cost: $\$ 14,875$

Funding Source: General Fund

\begin{tabular}{|cc|}
\hline (map ref \# 10) Woodring St South: N Booker St to N Simmons St \\
\hline Recommended Sidewalk Width & 5 feet \\
\hline Recommended Buffer Width: & $2-4$ feet \\
\hline Priority Index Ranking: & 6 (High) \\
\hline
\end{tabular}

Reason Selected: Will connect parts of existing network

Cost: $\$ 14,875$

Funding Source: General Fund 


\begin{tabular}{|cc|}
\hline (map ref \# 11) Griffin St South: N MLK Hwy to Sally Mae St \\
\hline Recommended Sidewalk Width & 5 feet \\
\hline Recommended Buffer Width: & $2-4$ feet \\
\hline Priority Index Ranking: & 31 (High) \\
\hline
\end{tabular}

Reason Selected: Fill in gaps of existing network

Cost: $\$ 25,750$

Funding Source: General Fund

\begin{tabular}{|cc|}
\hline (map ref \# 12) Katherine St South: N Prater St to N Booker St \\
\hline Recommended Sidewalk Width & 5 feet \\
\hline Recommended Buffer Width: & $2-4$ feet \\
\hline Priority Index Ranking: & 15 (High) \\
\hline
\end{tabular}

Reason Selected: Will connect to vital parts of existing sidewalk network

Cost: $\$ 32,925$

Funding Source: General Fund; Safe Routes to School

\begin{tabular}{|cc|}
\hline (map ref \# 13) N Lyon St West: Commercial St to Moeling St \\
\hline Recommended Sidewalk Width & 5 feet \\
\hline Recommended Buffer Width: & $2-4$ feet \\
\hline Priority Index Ranking: & 53 (Moderate) \\
\hline
\end{tabular}

Reason Selected: Located within 1/4 mile an elementary school

Cost: $\$ 10,242$

Funding Source: General Fund; Safe Routes to School

\begin{tabular}{|cc|}
\hline (map ref \# 14) N Lyon St East: Commercial St to Moeling St \\
\hline Recommended Sidewalk Width & 6 feet \\
\hline Recommended Buffer Width: & $2-4$ feet \\
\hline Priority Index Ranking: & 63 (Moderate) \\
\hline
\end{tabular}

Reason Selected: Located within 1/4 mile an elementary school

Cost: $\$ 10,099$

Funding Source: General Fund; Safe Routes to School

\begin{tabular}{|cc|}
\hline (map ref \# 15) N Blake St West: Moeling St to Geiffers St \\
\hline Recommended Sidewalk Width & 5 feet \\
\hline Recommended Buffer Width: & $2-4$ feet \\
\hline Priority Index Ranking: & 45 (High) \\
\hline
\end{tabular}

Reason Selected: Located within 1/4 mile a school

Cost: $\$ 43,634$

Funding Source: General Fund; Safe Routes to School 


\begin{tabular}{|cc|}
\hline \multicolumn{2}{|c|}{ (map ref \# 16) N Blake St East: Moeling St to Geiffers St } \\
\hline Recommended Sidewalk Width & 5 feet \\
\hline Recommended Buffer Width: & $2-4$ feet \\
\hline Priority Index Ranking: & 12 (High) \\
\hline
\end{tabular}

Reason Selected: Located within 1/4 mile a school

Cost: $\$ 47,364$

Funding Source: General Fund; Safe Routes to School

\begin{tabular}{|cc|}
\hline (map ref \# 17) N Shattuck St East: Moeling St to Opelousas St \\
\hline Recommended Sidewalk Width & 5 feet \\
\hline Recommended Buffer Width: & $2-4$ feet \\
\hline Priority Index Ranking: & 15 (High) \\
\hline
\end{tabular}

Reason Selected: Adjacent to an elementary school; will connect to existing sidewalk Cost: $\$ 60,517$

Funding Source: Safe Routes to School; General Fund

\begin{tabular}{|cc|}
\hline (map ref \# 18) N Simmons St West: Moeling St to Opelousas St \\
\hline Recommended Sidewalk Width & 5 feet \\
\hline Recommended Buffer Width: & $2-4$ feet \\
\hline Priority Index Ranking: & 15 (High) \\
\hline
\end{tabular}

Reason Selected: Will connect with numerous sidewalks

Cost: $\$ 65,176$

Funding Source: General Fund

\begin{tabular}{|cc|}
\hline (map ref \# 19) N Simmons St East: Moeling St to Opelousas St \\
\hline Recommended Sidewalk Width & 5 feet \\
\hline Recommended Buffer Width: & $2-4$ feet \\
\hline Priority Index Ranking: & 15 (High) \\
\hline
\end{tabular}

Reason Selected: Will connect with numerous sidewalks

Cost: $\$ 65,259$

Funding Source: Safe Routes to School; General Fund

\begin{tabular}{|cc|}
\hline (map ref \# 20) Cessford St North: N Prater St to N ${ }^{\text {st }}$ Ave \\
\hline Recommended Sidewalk Width & 5 feet \\
\hline Recommended Buffer Width: & $2-4$ feet \\
\hline Priority Index Ranking: & 12 (High) \\
\hline
\end{tabular}

Reason Selected: Will connect to existing sidewalk network

Cost: $\$ 99,424$

Funding Source: General Fund 


\begin{tabular}{|cc|}
\hline (map ref \# 21) Opelousas St South: N Shattuck St to N Simmons St \\
\hline Recommended Sidewalk Width & 5 feet \\
\hline Recommended Buffer Width: & $2-4$ feet \\
\hline Priority Index Ranking: & 15 (High) \\
\hline
\end{tabular}

Reason Selected: Within 1/4 mile to a school, important collector $\mathrm{rd}$.

Cost: $\$ 82,194$

Funding Source: Safe Routes to School; General Fund

\begin{tabular}{|cc|}
\hline (map ref \# 22) Fournet St North: N Enterprise Blvd to N Shattuck St \\
\hline Recommended Sidewalk Width & 5 feet \\
\hline Recommended Buffer Width: & $2-4$ feet \\
\hline Priority Index Ranking: & 95 (Moderate) \\
\hline
\end{tabular}

Reason Selected: connects with existing sidewalk network

Cost: $\$ 53,425$

Funding Source: General Fund

\begin{tabular}{|cc|}
\hline (map ref \# 23) Pedestrian Connector Path: N Shattuck St to Fournet St \\
\hline Recommended Sidewalk Width & 5 feet \\
\hline Recommended Buffer Width: & $2-4$ feet \\
\hline Priority Index Ranking: & 42 (High) \\
\hline
\end{tabular}

Reason Selected: Within 1/4 mile to a school, will serve as a short-cut between two main roads. Cost: $\$ 2,076$

Funding Source: Safe Routes to School; General Fund

\begin{tabular}{|cc|}
\hline \multicolumn{2}{|c|}{ (map ref \# 24) Jackson St South: N Bank St to N Ryan St } \\
\hline Recommended Sidewalk Width & 5 feet \\
\hline Recommended Buffer Width: & $2-4$ feet \\
\hline Priority Index Ranking: & 95 (Moderate) \\
\hline
\end{tabular}

Reason Selected: Will connect to an existing sidewalk network

Cost: $\$ 74,775$

Funding Source: General Fund

\begin{tabular}{|cc|}
\hline \multicolumn{2}{|c|}{ (map ref \# 25) N Ryan St East: S Railroad Ave to Jackson St } \\
\hline Recommended Sidewalk Width & 5 feet \\
\hline Recommended Buffer Width: & $2-4$ feet \\
\hline Priority Index Ranking: & 42 (High) \\
\hline
\end{tabular}

Reason Selected: Will connect to an existing sidewalk; will connect different parts of community together

Cost: $\$ 14,850$

Funding Source: General Fund 


\begin{tabular}{|cc|}
\hline (map ref \# 26) Church St North: Ford St to Kirkman St \\
\hline Recommended Sidewalk Width & 5 feet \\
\hline Recommended Buffer Width: & $2-4$ feet \\
\hline Priority Index Ranking: & 53 (Moderate) \\
\hline
\end{tabular}

Reason Selected: Will connect to an existing sidewalk network

Cost: $\$ 10,725$

Funding Source: General Fund 
The City of Lake Charles

\section{Central Lake Charles}

This area of the City has the downtown and lakeshore district included in it. This area is a destination for commuters as well as people wanting to recreate by the lakeshore. Overall, it has a household income range on the higher end of the AMI, which could mean most people have the privilege of owning a car. The intensive commercial land-use makes this area having a complete sidewalk network very important. 
Table 4: Central Lake Charles Recommended Sidewalks

\begin{tabular}{|c|c|c|c|c|}
\hline $\begin{array}{l}\text { Map } \\
\text { Ref\# }\end{array}$ & Sidewalk Name & Segment Extents & $\begin{array}{l}\text { Priority } \\
\text { Range }\end{array}$ & $\begin{array}{l}\text { Length } \\
\text { (Feet) }\end{array}$ \\
\hline 27 & VE Washington Ave West Side & I-10 Srvc Rd to Belden St & Moderate & 302 \\
\hline 28 & Enterprise Blvd. West Side & Mill St. to Belden St. & High & 1,313 \\
\hline 29 & S Shattuck St East Side & Belden St to Carter St & High & 1,652 \\
\hline 30 & I-10 Srv. Rd North & Belden St to Albert St & Moderate & 201 \\
\hline 31 & Belden St. South Side & Albert St to Existing Sidewalk & Moderate & 1,112 \\
\hline 32 & Fruge St. South Side & Malcom St to Hwy 14 & Moderate & 510 \\
\hline 33 & McNabb St West Side & Fruge St to Broad St & Low & 2601 \\
\hline 34 & Winterhalter St. South Side & S Shattuck St to Albert St & Moderate & 2,700 \\
\hline 35 & Pine St. North Side & Bank St to Louisiana Ave & High & 418 \\
\hline 36 & Pine St. South Side & Bank St to Louisiana Ave & High & 395 \\
\hline 37 & Evans St South Side & S Shattuck St to Prater St & High & 1,340 \\
\hline 38 & Cline St South Side & Holmes St to S MLK Hwy & Moderate & 746 \\
\hline 39 & Cline St North Side & Holmes St to S MLK Hwy & Moderate & 391 \\
\hline 40 & Mt Talbot St South Side & McNabb St to Ball Fields & Low & 1451 \\
\hline 41 & Division St North Side & Bank St to Louisiana Ave & High & 420 \\
\hline 42 & Division St South Side & Bank St to Louisiana Ave & High & 420 \\
\hline 43 & Louisiana Ave West Side & Division St to Clements St & High & 644 \\
\hline 44 & Broad St. South Side & 1st Ave and Louisiana Ave & Moderate & 1,232 \\
\hline 45 & Broad St. North Side & VE Washington Ave to 1st Ave & High & 204 \\
\hline 46 & Broad St. North Side 2 & S Lyon St to Existing Sidewalk & Moderate & 157 \\
\hline 47 & Broad St. North Side 3 & 8th Ave to McNabb St & Low & 3,333 \\
\hline 48 & Enterprise Blvd. West Side 2 & Broad St to Existing Sidewalk & High & 191 \\
\hline 49 & Enterprise Blvd. East & Broad St to Existing Sidewalk & High & 280 \\
\hline 50 & Gerstner Memorial Dr. East Side & Broad St to 4th St & Low & 1,924 \\
\hline 51 & Gerstner Memorial Dr. West Side & Broad St to Existing Sidewalk & Low & 2,996 \\
\hline 52 & 2nd St South Side & Enterprise Blvd to 2nd Ave & Moderate & 1,680 \\
\hline 53 & 3rd St. South Side & Enterprise Blvd to 3rd Ave & Moderate & 2,513 \\
\hline 54 & 3rd St. North Side & 6th Ave to Gerstner Memorial Dr & Moderate & 2,619 \\
\hline 55 & 3rd St. South Side 2 & 6th Ave to Gerstner Memorial Dr & Low & 2,624 \\
\hline 56 & 3rd St South Side 3 & Gernstner Memerial Dr to McNabb St & Low & 1,246 \\
\hline 57 & 4th St. North Side & Louisiana Ave to Enterprise Blvd & Moderate & 316 \\
\hline 58 & 4th St. South Side & Louisiana Ave to Enterprise Blvd & Moderate & 323 \\
\hline 59 & 5th St. North Side & Louisiana Ave to Enterprise Blvd & High & 317 \\
\hline 60 & 5th St. South Side & Louisiana Ave to Existing Sidewalk & High & 185 \\
\hline 61 & 6th St North Side & Bank St to Louisiana Ave & Moderate & 429 \\
\hline 62 & 6th St South Side & Bank St to Enterprise Blvd & Moderate & 798 \\
\hline 63 & 1st Ave. East Side 2 & Broad St to 12 th St & High & 5,280 \\
\hline 64 & 6th St. North Side 2 & 5th Ave to 6th Ave & Moderate & 647 \\
\hline 65 & 6th Ave. East Side & 6th St to 9th St & Moderate & 1,058 \\
\hline 66 & 6th Ave. East Side 2 & Legion St to 12 th St & Moderate & 1,250 \\
\hline 67 & Common St. West Side & Clarence St to 17 th St & High & 5,943 \\
\hline 68 & Common St. East Side & 6th St to 17 th St & Moderate & 5,038 \\
\hline
\end{tabular}


Figure 16: Central Lake Charles Recommended Sidewalks

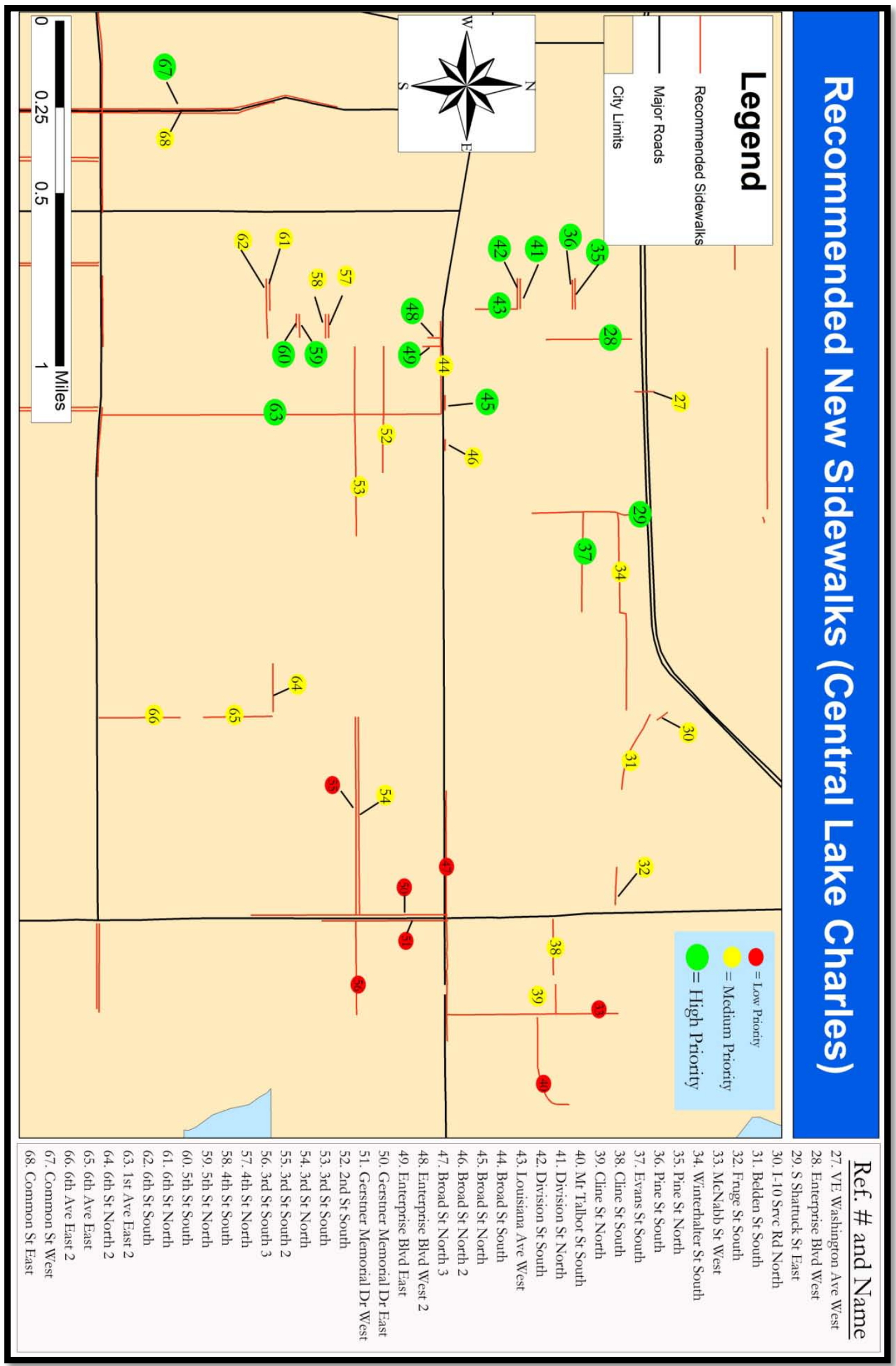




\section{Central Lake Charles Area}

\begin{tabular}{|cc|}
\hline (map ref \#27) VE Washington Ave West: I-10 Service Rd to Belden St \\
\hline Recommended Sidewalk Width & 5 feet \\
\hline Recommended Buffer Width: & $2-4$ feet \\
\hline Priority Index Ranking: & 75 (Moderate) \\
\hline
\end{tabular}

Reason Selected: Will connect to existing sidewalk network

Cost: $\$ 7,543$

Funding Source: General Fund

\begin{tabular}{|cc|}
\hline (map ref \# 28) Enterprise Blvd West: Mill St to Belden St \\
\hline Recommended Sidewalk Width & 6 feet \\
\hline Recommended Buffer Width: & $4-6$ feet \\
\hline Priority Index Ranking: & 15 (High) \\
\hline
\end{tabular}

Reason Selected: Will connect to existing sidewalk network

Cost: $\$ 39,375$

Funding Source: General Fund

\begin{tabular}{|cc|}
\hline (map ref \# 29) S Shattuck St East: Belden St to Carter St \\
\hline Recommended Sidewalk Width & 6 feet \\
\hline Recommended Buffer Width: & $4-6$ feet \\
\hline Priority Index Ranking: & 9 (High) \\
\hline
\end{tabular}

Reason Selected: Will connect to existing sidewalk network

Cost: $\$ 49,560$

Funding Source: General Fund

\begin{tabular}{|cc|}
\hline \multicolumn{2}{|c|}{ (map ref \# 30) I-10 Service Rd North: Belden St to Albert St } \\
\hline Recommended Sidewalk Width & 5 feet \\
\hline Recommended Buffer Width: & $2-4$ feet \\
\hline Priority Index Ranking: & 95 (Moderate) \\
\hline
\end{tabular}

Reason Selected: Will connect to existing sidewalk network

Cost: $\$ 5,016$

Funding Source: General Fund

\begin{tabular}{|cc|}
\hline \multicolumn{2}{|c|}{ (map ref \# 31) Belden St South: Albert St to Existing Sidewalk } \\
\hline Recommended Sidewalk Width & 5 feet \\
\hline Recommended Buffer Width: & $2-4$ feet \\
\hline Priority Index Ranking: & 75 (Moderate) \\
\hline
\end{tabular}

Reason Selected: Will connect to existing sidewalk network

Cost: $\$ 27,810$

Funding Source: General Fund 


\begin{tabular}{|cc|}
\hline \multicolumn{2}{|c|}{ (map ref \# 32) Fruge St South: Malcolm St to Hwy 14} \\
\hline Recommended Sidewalk Width & 5 feet \\
\hline Recommended Buffer Width: & $2-4$ feet \\
\hline Priority Index Ranking: & 109 (Moderate) \\
\hline
\end{tabular}

Reason Selected: Will connect to existing sidewalk network

Cost: $\$ 12,749$

Funding Source: General Fund,

\begin{tabular}{|cc|}
\hline (map ref \#33) McNabb St West: Fruge St to Broad St \\
\hline Recommended Sidewalk Width & 5 feet \\
\hline Recommended Buffer Width: & $2-4$ feet \\
\hline Priority Index Ranking: & 117 (Low) \\
\hline
\end{tabular}

Reason Selected: Will connect to existing sidewalk network

Cost: $\$ 65,025$

Funding Source: General Fund

\begin{tabular}{|cc|}
\hline (map ref \# 34) Winterhalter St South: S Shattuck St to Albert St \\
\hline Recommended Sidewalk Width & 5 feet \\
\hline Recommended Buffer Width: & $2-4$ feet \\
\hline Priority Index Ranking: & 75 (Moderate) \\
\hline
\end{tabular}

Reason Selected: Will connect to existing sidewalk network

Cost: $\$ 67,500$

Funding Source: General Fund

\begin{tabular}{|cc|}
\hline (map ref \# 35) Pine St North: Bank St to Louisiana Ave \\
\hline Recommended Sidewalk Width & 5 feet \\
\hline Recommended Buffer Width: & $2-4$ feet \\
\hline Priority Index Ranking: & 31 (High) \\
\hline
\end{tabular}

Reason Selected: Will connect to existing sidewalk network

Cost: $\$ 10,453$

Funding Source: General Fund

\begin{tabular}{|cc|}
\hline (map ref \# 36) Pine St South: Bank St to Louisiana Ave \\
\hline Recommended Sidewalk Width & 5 feet \\
\hline Recommended Buffer Width: & $2-4$ feet \\
\hline Priority Index Ranking: & 31 (High) \\
\hline
\end{tabular}

Reason Selected: Will connect to existing sidewalk network

Cost: $\$ 9,871$

Funding Source: General Fund 


\begin{tabular}{|cc|}
\hline \multicolumn{2}{|c|}{ (map ref \# 37) Evans St South: S Shattuck St to Prater St } \\
\hline Recommended Sidewalk Width & 5 feet \\
\hline Recommended Buffer Width: & $2-4$ feet \\
\hline Priority Index Ranking: & 42 (High) \\
\hline
\end{tabular}

Reason Selected: Will connect to existing sidewalk network

Cost: $\$ 33,500$

Funding Source: General Fund

\begin{tabular}{|cc|}
\hline (map ref \# 38) Cline St South: Holmes St to S MLK Hwy \\
\hline Recommended Sidewalk Width & 5 feet \\
\hline Recommended Buffer Width: & $2-4$ feet \\
\hline Priority Index Ranking: & 95 (Moderate) \\
\hline
\end{tabular}

Reason Selected: Will connect existing sidewalk network

Cost: $\$ 18,650$

Funding Source: General Fund

\begin{tabular}{|cc|}
\hline (map ref \# 39) Cline St North: Holmes St to S MLK Hwy \\
\hline Recommended Sidewalk Width & 5 feet \\
\hline Recommended Buffer Width: & $2-4$ feet \\
\hline Priority Index Ranking: & 95 (Moderate) \\
\hline
\end{tabular}

Reason Selected: Will connect to existing sidewalk network facility

Cost: $\$ 9,775$

Funding Source: General Fund

\begin{tabular}{|cc|}
\hline (map ref \# 40) Mt Talbot St: McNabb St to Baseball Fields \\
\hline Recommended Sidewalk Width & 5 feet \\
\hline Recommended Buffer Width: & $2-4$ feet \\
\hline Priority Index Ranking: & 127 (Low) \\
\hline
\end{tabular}

Reason Selected: Will connect to existing sidewalk network

Cost: $\$ 36,275$

Funding Source: General Fund

\begin{tabular}{|rc|}
\hline (map ref \# 41) Division St North: Bank St to Louisiana Ave \\
\hline Recommended Sidewalk Width & 5 feet \\
\hline Recommended Buffer Width: & $2-4$ feet \\
\hline Priority Index Ranking: & 4 (High) \\
\hline
\end{tabular}

Reason Selected: Will connect to existing sidewalk network

Cost: $\$ 10,500$

Funding Source: General Fund 


\begin{tabular}{|cc|}
\hline \multicolumn{2}{|c|}{ (map ref \# 42) Division St South: Bank St to Louisiana Ave } \\
\hline Recommended Sidewalk Width & 5 feet \\
\hline Recommended Buffer Width: & $2-4$ feet \\
\hline Priority Index Ranking: & 6 (High) \\
\hline
\end{tabular}

Reason Selected: Will connect to existing sidewalk network

Cost: $\$ 10,500$

Funding Source: General Fund

\begin{tabular}{|cc|}
\hline (map ref \# 43) Louisiana Ave West: Division St to Clements St \\
\hline Recommended Sidewalk Width & 5 feet \\
\hline Recommended Buffer Width: & $2-4$ feet \\
\hline Priority Index Ranking: & 3 (High) \\
\hline
\end{tabular}

Reason Selected: Will connect to existing sidewalk network

Cost: $\$ 16,100$

Funding Source: General Fund

\begin{tabular}{|cc|}
\hline (map ref \# 44) Broad St South: $1^{\text {st }}$ Ave to Louisiana Ave \\
\hline Recommended Sidewalk Width & 6 feet \\
\hline Recommended Buffer Width: & $4-6$ feet \\
\hline Priority Index Ranking: & 63 (Moderate) \\
\hline
\end{tabular}

Reason Selected: Important Collector/Arterial roadway

Cost: $\$ 39,376$

Funding Source: General Fund

\begin{tabular}{|cc|}
\hline (map ref \# 45) Broad St North: VE Washington Ave to $1^{\text {st }}$ Ave \\
\hline Recommended Sidewalk Width & 6 feet \\
\hline Recommended Buffer Width: & $4-6$ feet \\
\hline Priority Index Ranking: & 42 (High) \\
\hline
\end{tabular}

Reason Selected: Important Collector/Arterial roadway

Cost: $\$ 6,121$

Funding Source: General Fund

\begin{tabular}{|cc|}
\hline (map ref \# 46) Broad St North 2: S Lyon St to Existing Sidewalk \\
\hline Recommended Sidewalk Width & 6 feet \\
\hline Recommended Buffer Width: & $4-6$ feet \\
\hline Priority Index Ranking: & 53 (Moderate) \\
\hline
\end{tabular}

Reason Selected: Important Collector/Arterial roadway

Cost: $\$ 4,714$

Funding Source: General Fund 


\begin{tabular}{|cc|}
\hline (map ref \# 47) Broad St North 3: $8^{\text {th }}$ Ave to McNabb St \\
\hline Recommended Sidewalk Width & 6 feet \\
\hline Recommended Buffer Width: & $4-6$ feet \\
\hline Priority Index Ranking: & 117 (Low) \\
\hline
\end{tabular}

Reason Selected: Important Collector/Arterial roadway

Cost: $\$ 99,975$

Funding Source: General Fund

\begin{tabular}{|cc|}
\hline (map ref \# 48) Enterprise Blvd West: Broad St to Existing Sidewalk \\
\hline Recommended Sidewalk Width & 6 feet \\
\hline Recommended Buffer Width: & $4-6$ feet \\
\hline Priority Index Ranking: & 42 (High) \\
\hline
\end{tabular}

Reason Selected: Important Collector/Arterial roadway

Cost: $\$ 5,734$

Funding Source: General Fund

\begin{tabular}{|rc|}
\hline (map ref \# 49) Enterprise Blvd East: Broad St to Existing Sidewalk \\
\hline Recommended Sidewalk Width & 6 feet \\
\hline Recommended Buffer Width: & $4-6$ feet \\
\hline Priority Index Ranking: & 31 (High) \\
\hline
\end{tabular}

Reason Selected: Important Collector/Arterial roadway

Cost: $\$ 8,406$

Funding Source: General Fund

\begin{tabular}{|cc|}
\hline (map ref \# 50) Gerstner Memorial Dr East: Broad St to $4^{\text {th }}$ St \\
\hline Recommended Sidewalk Width & 6 feet \\
\hline Recommended Buffer Width: & $4-6$ feet \\
\hline Priority Index Ranking: & 124 (Low) \\
\hline
\end{tabular}

Reason Selected: Important Collector/Arterial roadway

Cost: $\$ 57,733$

Funding Source: General Fund

\begin{tabular}{|cc|}
\hline (map ref \# 51) Gerstner Memorial Dr West: Broad St to Existing Sidewalk \\
\hline Recommended Sidewalk Width & 6 feet \\
\hline Recommended Buffer Width: & $4-6$ feet \\
\hline Priority Index Ranking: & 124 (Low) \\
\hline
\end{tabular}

Reason Selected: Important Collector/Arterial roadway $r$

Cost: $\$ 89,873$

Funding Source: General Fund 


\begin{tabular}{|cc|}
\hline \multicolumn{2}{|c|}{ (map ref \# 52) $2^{\text {nd }}$ St South: Enterprise Blvd to $2^{\text {nd }}$ Ave } \\
\hline Recommended Sidewalk Width & 5 feet \\
\hline Recommended Buffer Width: & $2-4$ feet \\
\hline Priority Index Ranking: & 53 (Moderate) \\
\hline
\end{tabular}

Reason Selected: Will connect to an existing sidewalk; will connect different parts of community Cost: $\$ 42,000$

Funding Source: General Fund

\begin{tabular}{|cc|}
\hline \multicolumn{2}{|c|}{ (map ref \# 53) $3^{\text {rd }}$ St South: Enterprise Blvd to $3^{\text {rd }}$ Ave } \\
\hline Recommended Sidewalk Width & 5 feet \\
\hline Recommended Buffer Width: & $2-4$ feet \\
\hline Priority Index Ranking: & 82 (Moderate) \\
\hline
\end{tabular}

Reason Selected: Within 1/4 mile to a school, Will connect to an existing sidewalk; will connect different parts of community together

Cost: $\$ 62,834$

Funding Source: Safe Routes to School; General Fund

\begin{tabular}{|cc|}
\hline (map ref \# 54) $3^{\text {rd }}$ St North: $6^{\text {th }}$ Ave to Gerstner Memorial Dr \\
\hline Recommended Sidewalk Width & 5 feet \\
\hline Recommended Buffer Width: & $2-4$ feet \\
\hline Priority Index Ranking: & 113 (Moderate) \\
\hline
\end{tabular}

Reason Selected: Within 1/4 mile to a school, Will connect to an existing sidewalk; will connect different parts of community together

Cost: $\$ 65,471$

Funding Source: Safe Routes to School; General Fund

\begin{tabular}{|cc|}
\hline (map ref \# 55) $3^{\text {rd }}$ St South 2: $6^{\text {th }}$ Ave to Gerstner Memorial Dr \\
\hline Recommended Sidewalk Width & 5 feet \\
\hline Recommended Buffer Width: & $2-4$ feet \\
\hline Priority Index Ranking: & 117 (Low) \\
\hline
\end{tabular}

Reason Selected: Within 1/4 mil to a school, will connect different parts of community together Cost: $\$ 65,597$

Funding Source: Safe Routes to School; General Fund

\begin{tabular}{|cc|}
\hline (map ref \# 56) $3^{\text {rd }}$ St South 3: Gerstner Memorial Dr to McNabb St \\
\hline Recommended Sidewalk Width & 5 feet \\
\hline Recommended Buffer Width: & $2-4$ feet \\
\hline Priority Index Ranking: & 117 (Low) \\
\hline
\end{tabular}

Reason Selected: Will connect to an existing sidewalk; will connect different parts of community together

Cost: $\$ 31,150$

Funding Source: General Fund; 


\begin{tabular}{|cc|}
\hline (map ref \# 57) $4^{\text {th }}$ St North: Louisiana Ave to Enterprise Blvd \\
\hline Recommended Sidewalk Width & 5 feet \\
\hline Recommended Buffer Width: & $2-4$ feet \\
\hline Priority Index Ranking: & 53 (Moderate) \\
\hline
\end{tabular}

Reason Selected: Within 1/4 mile to a school, will connect different parts of community together Cost: $\$ 7,909$

Funding Source: Safe Routes to School; General Fund

\begin{tabular}{|cc|}
\hline \multicolumn{2}{|c|}{ (map ref \# 58) $4^{\text {th }}$ St South: Louisiana Ave to Enterprise Blvd } \\
\hline Recommended Sidewalk Width & 5 feet \\
\hline Recommended Buffer Width: & $2-4$ feet \\
\hline Priority Index Ranking: & 53 (Moderate) \\
\hline
\end{tabular}

Reason Selected: Within 1/4 mile to a school, will connect different parts of community together Cost: $\$ 8,069$

Funding Source: Safe Routes to School; General Fund

\begin{tabular}{|cc|}
\hline (map ref \# 59) $5^{\text {th }}$ St North: Louisiana Ave to Enterprise Blvd \\
\hline Recommended Sidewalk Width & 5 feet \\
\hline Recommended Buffer Width: & $2-4$ feet \\
\hline Priority Index Ranking: & 15 (High) \\
\hline
\end{tabular}

Reason Selected: Within 1/4 mile to a school, will connect different parts of community together Cost: $\$ 7,931$

Funding Source: Safe Routes to School; General Fund

\begin{tabular}{|cc|}
\hline (map ref \# 60) $5^{\text {th }}$ St South: Louisiana Ave to Existing Sidewalk \\
\hline Recommended Sidewalk Width & 5 feet \\
\hline Recommended Buffer Width: & $2-4$ feet \\
\hline Priority Index Ranking: & 15 (High) \\
\hline
\end{tabular}

Reason Selected: Within 1/4 mile to a school, will connect different parts of community together Cost: $\$ 4,626$

Funding Source: Safe Routes to School; General Fund

\begin{tabular}{|c|c|}
\hline Recommended Sidewalk Width & 5 feet \\
\hline Recommended Buffer Width: & $2-4$ feet \\
\hline Priority Index Ranking: & 53 (Moderate) \\
\hline
\end{tabular}

Reason Selected: Will connect to an existing sidewalk; Within 1/4 mile to a school

Cost: $\$ 10,730$

Funding Source: Safe Routes to School; General Fund 


\begin{tabular}{|cc|}
\hline \multicolumn{2}{|c|}{ (map ref \# 62) $6^{\text {th }}$ St North: Bank St to Enterprise Blvd } \\
\hline Recommended Sidewalk Width & 5 feet \\
\hline Recommended Buffer Width: & $2-4$ feet \\
\hline Priority Index Ranking: & 63 (Moderate) \\
\hline
\end{tabular}

Reason Selected: Will connect to an existing sidewalk; will connect different parts of community together

Cost: $\$ 19,945$

Funding Source: General Fund

\begin{tabular}{|cc|}
\hline \multicolumn{2}{|c|}{ (map ref \# 63) $1^{\text {st }}$ Ave East 2: Broad St to $12^{\text {th }}$ St } \\
\hline Recommended Sidewalk Width & 5 feet \\
\hline Recommended Buffer Width: & $2-4$ feet \\
\hline Priority Index Ranking: & 1 (High) \\
\hline
\end{tabular}

Reason Selected: Will connect to an existing sidewalk; will connect different parts of community together

Cost: $\$ 132,000$

Funding Source: General Fund

\begin{tabular}{|cc|}
\hline \multicolumn{2}{|c|}{ (map ref \# 64) $6^{\text {th }}$ St North 2: $5^{\text {th }}$ Ave to $6^{\text {th }}$ Ave } \\
\hline Recommended Sidewalk Width & 5 feet \\
\hline Recommended Buffer Width: & $2-4$ feet \\
\hline Priority Index Ranking: & 104 (Moderate) \\
\hline
\end{tabular}

Reason Selected: Will connect to existing sidewalk network

Cost: $\$ 16,168$

Funding Source: General Fund

\begin{tabular}{|cc|}
\hline \multicolumn{2}{|c|}{ (map ref \# 65) $6^{\text {th }}$ Ave East: $6^{\text {th }}$ St to $9^{\text {th }}$ St } \\
\hline Recommended Sidewalk Width & 5 feet \\
\hline Recommended Buffer Width: & $2-4$ feet \\
\hline Priority Index Ranking: & 82 (Moderate) \\
\hline
\end{tabular}

Reason Selected: Will connect to an existing sidewalk; will connect different parts of community together

Cost: $\$ 26,454$

Funding Source: General Fund

\begin{tabular}{|cc|}
\hline \multicolumn{2}{|c|}{ (map ref \# 66) $6^{\text {th }}$ Ave East 2: Legion St to $12^{\text {th }}$ St } \\
\hline Recommended Sidewalk Width & 5 feet \\
\hline Recommended Buffer Width: & $2-4$ feet \\
\hline Priority Index Ranking: & 82 (Moderate) \\
\hline
\end{tabular}

Reason Selected: Will connect to an existing sidewalk; will connect different parts of community together

Cost: $\$ 31,245$

Funding Source: General Fund 


\begin{tabular}{|cc|}
\hline \multicolumn{2}{|c|}{ (map ref \# 67) Common St West: Clarence St to $17^{\text {th }}$ St } \\
\hline Recommended Sidewalk Width & 5 feet \\
\hline Recommended Buffer Width: & $4-6$ feet \\
\hline Priority Index Ranking: & 15 (High) \\
\hline
\end{tabular}

Reason Selected: Important Arterial/Collector roadway.

Cost: $\$ 148,578$

Funding Source: General Fund

\begin{tabular}{|cc|}
\hline \multicolumn{2}{|c|}{ (map ref \# 68) Church St North: Ford St to Kirkman St } \\
\hline Recommended Sidewalk Width & 5 feet \\
\hline Recommended Buffer Width: & $4-6$ feet \\
\hline Priority Index Ranking: & 63 (Moderate) \\
\hline
\end{tabular}

Reason Selected: Will connect to an existing sidewalk; will connect different parts of community together

Cost: $\$ 125,942$

Funding Source: General Fund

\section{South-Central Lake Charles}

This area of the City is mostly residential in nature, but does have some commercial and industrial uses. It has numerous schools and many main roads that have gaps in their network. Overall, it has a household income range at the center of the AMI, which could mean that many of its residents are with the use of a car. This area of the city has the potential of having a few multi-use paths that may fit into the overall non-motorized network nicely. 
Table 5: South-Central Lake Chalres Recommended Sidewalks

\begin{tabular}{|c|c|c|c|c|}
\hline $\begin{array}{l}\text { Map } \\
\text { Ref\# }\end{array}$ & Sidewalk Name & Segment Extents & $\begin{array}{c}\text { Priority } \\
\text { Range }\end{array}$ & $\begin{array}{l}\text { Length } \\
\text { (Feet) }\end{array}$ \\
\hline 69 & E. Sallier St. North Side & Ryan St to Kirkman St & Moderate & 2,868 \\
\hline 70 & E. Sallier St. North Side 2 & Bank St to Enterprise Blvd & Moderate & 953 \\
\hline 71 & 12th St. North Side & 1st Ave to 2 nd Ave & Moderate & 929 \\
\hline 72 & 12th St. North Side 2 & Gerstner Memorial Dr to Russell St & High & 1,181 \\
\hline 73 & 12th St. South Side & Gerstner Memorial Dr to Russell St & High & 1,140 \\
\hline 74 & Moss St. West Side & 12th St. to 15th St. & Moderate & 1,386 \\
\hline 75 & Moss St. East Side & 12th St. to 15 th St. & High & 1,384 \\
\hline 76 & 13th St. North Side & Enterprise Blvd. to Moss St. & Moderate & 2,365 \\
\hline 77 & 13th St South Side & Moss St. to Enterprise Blvd. & Moderate & 2,363 \\
\hline 78 & 14th St North Side & Bank St. to Enterprise Blvd. & Moderate & 977 \\
\hline 79 & 14th St South Side & Bank St. to Enterprise Blvd. & Moderate & 973 \\
\hline 80 & 15th St. North Side & Hodges St to Bank St & Moderate & 2,637 \\
\hline 81 & 15th St. South Side & Hodges St to Bank St & Moderate & 2,641 \\
\hline 82 & Bank St. West Side & Gulf St. to 12 th St. & High & 3,840 \\
\hline 83 & Bank St. East Side & Gulf St. to 12 th St. & High & 3,830 \\
\hline 84 & 1st Ave. West Side & 12th St to E Prien Lake Rd & High & 5,369 \\
\hline 85 & 1st Ave. East Side & 12th St to E Prien Lake Rd & High & 5,362 \\
\hline 86 & 18th St. North Side & Ryan St. to Common St. & Moderate & 1,406 \\
\hline 87 & 18th St. South Side & Ryan St. to Common St. & High & 1,409 \\
\hline 88 & Hwy 14 West Side 2 & Rail Road Tracks to Taylor St. & Moderate & 4,509 \\
\hline 89 & E Prien Lake Rd North Side & Existing Sidewalk to Existing Sidewalk & Moderate & 1,393 \\
\hline 90 & E Prien Lake Rd North Side 2 & Kirkman St to Existing Sidewalk & High & 695 \\
\hline 91 & E Prien Lake Rd North Side 3 & Burton St to 2nd Ave. & High & 2,587 \\
\hline 92 & E Prien Lake Rd North Side 4 & 5th Ave to Hwy 14 & Moderate & 2,754 \\
\hline 93 & Kirkman St West Side & Prien Lake Rd to Walters St & High & 5,358 \\
\hline 94 & Kirkman St East Side & Prien Lake Rd to Madeline St & High & 4,698 \\
\hline 95 & Azalea St South & Kirkman St to Louisana Ave & Moderate & 1,300 \\
\hline 96 & 5th Ave West Side & College St to E. McNeese St & Low & 7,537 \\
\hline 97 & 5th Ave. East Side & College St to E. McNeese St & Low & 7,542 \\
\hline 98 & Gerstner Memorial Dr East & E Prien Lake Rd to McNeese Farm Rd & Moderate & 4,580 \\
\hline 99 & Hwy 14 West Side & Coolidge St to McNeese St & Moderate & 3,868 \\
\hline 100 & Madeline St South Side & Common St to Kirkman St & High & 1,310 \\
\hline 101 & Illinois St. South Side & Brentwood St. to E. Walton St. & Moderate & 1,038 \\
\hline 102 & Kirkman St West Side 2 & Gayle St to McCall St & Moderate & 1,547 \\
\hline 103 & Kirkman St East Side 2 & Walters St to McCall St & Moderate & 1,213 \\
\hline 104 & University Dr. West Side & McNeese St to Existing Sidewalk & Moderate & 453 \\
\hline 105 & E. McNeese St South Side & Ryan St to Common St & Low & 1,363 \\
\hline 106 & E McNeese St. North Side & Gerstner Memorial Dr to Existing & Low & 5,297 \\
\hline
\end{tabular}


Figure 17: South-Central Lake Charles Recommended Sidewalks
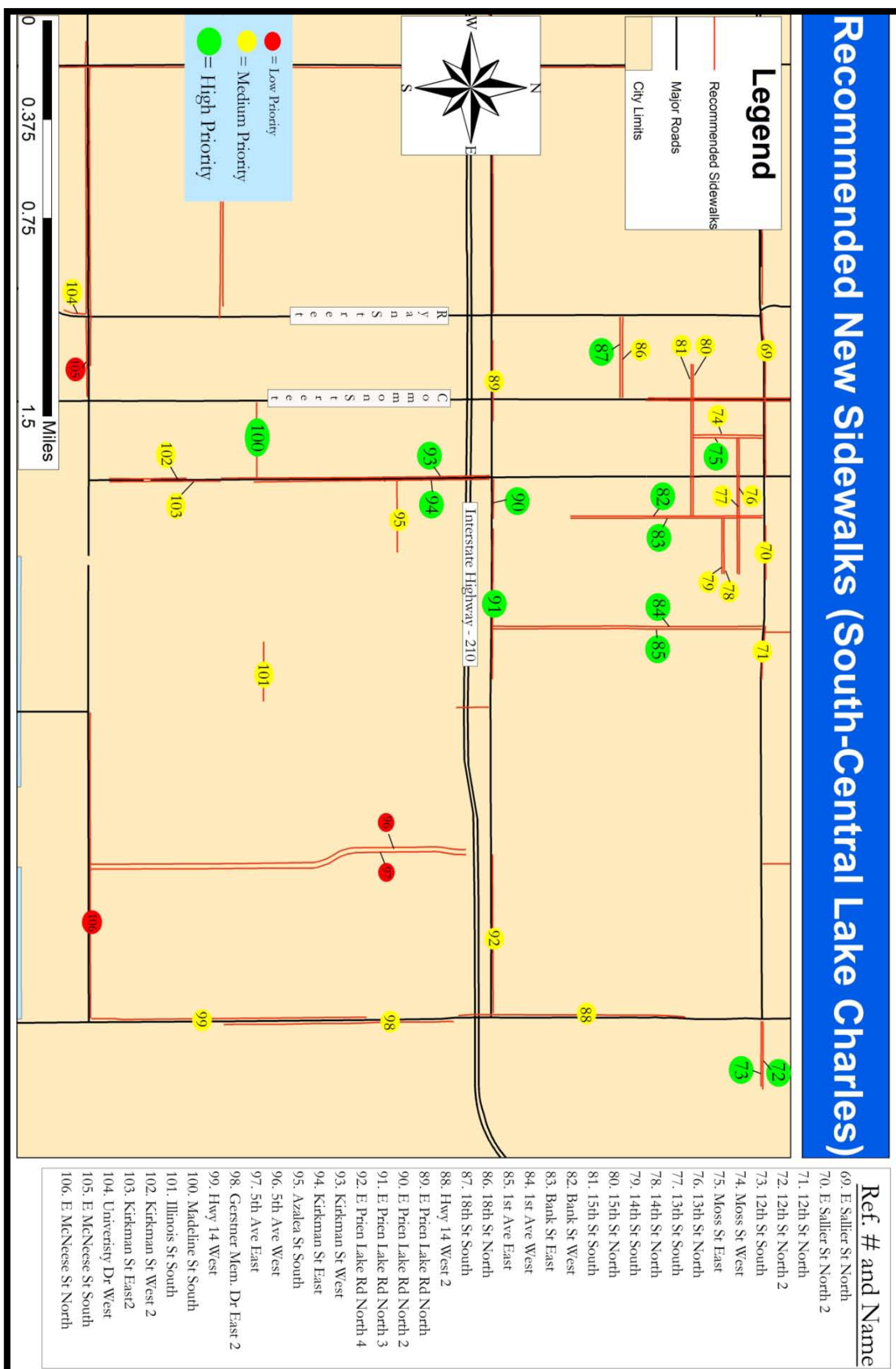


\section{South-Central Lake Charles Area}

\begin{tabular}{|cc|}
\hline \multicolumn{2}{|c|}{ (map ref \#69) E Sallier St North: Ryan St to Kirkman St } \\
\hline Recommended Sidewalk Width & 5 feet \\
\hline Recommended Buffer Width: & $4-6$ feet \\
\hline Priority Index Ranking: & 75 (Moderate) \\
\hline
\end{tabular}

Reason Selected: Located within 1/4 mile to a high school

Cost: $\$ 71,709$

Funding Source: Safe Routes to School, General Fund

\begin{tabular}{|rc|}
\hline (map ref \# 70) E Sallier St North 2: Bank St to Enterprise Blvd \\
\hline Recommended Sidewalk Width & 5 feet \\
\hline Recommended Buffer Width: & $4-6$ feet \\
\hline Priority Index Ranking: & 82 (Moderate) \\
\hline
\end{tabular}

Reason Selected: Important Collector/Arterial roadway

Cost: $\$ 23,823$

Funding Source: General Fund

\begin{tabular}{|cc|}
\hline \multicolumn{2}{|c|}{ (map ref \# 71) $12^{\text {th }}$ St North: $1^{\text {st }}$ Ave to $2^{\text {nd }}$ Ave } \\
\hline Recommended Sidewalk Width & 5 feet \\
\hline Recommended Buffer Width: & $2-4$ feet \\
\hline Priority Index Ranking: & 63 (Moderate) \\
\hline
\end{tabular}

Reason Selected: Will connect to existing sidewalk network

Cost: $\$ 23,229$

Funding Source: General Fund

\begin{tabular}{|cc|}
\hline (map ref \# 72) $12^{\text {th }}$ St North 2: Gerstner Memorial Dr to Russell St \\
\hline Recommended Sidewalk Width & 5 feet \\
\hline Recommended Buffer Width: & $2-4$ feet \\
\hline Priority Index Ranking: & 15 (High) \\
\hline
\end{tabular}

Reason Selected: Located within 1/4 mile to a school

Cost: $\$ 29,528$

Funding Source: Safe Routes to School; General Fund

\begin{tabular}{|cc|}
\hline (map ref \# 73) $12^{\text {th }}$ St South: Gerstner Memorial Dr to Russell St \\
\hline Recommended Sidewalk Width & 5 feet \\
\hline Recommended Buffer Width: & $2-4$ feet \\
\hline Priority Index Ranking: & 15 (High) \\
\hline
\end{tabular}

Reason Selected: Located within 1/4 mile an elementary school; Will connect to existing sidewalk network

Cost: $\$ 28,509$

Funding Source: General Fund, Safe Routes to School 


\begin{tabular}{|cc|}
\hline \multicolumn{2}{|c|}{ (map ref \# 74) Moss St West: $12^{\text {th }}$ St to $15^{\text {th }}$ St } \\
\hline Recommended Sidewalk Width & 5 feet \\
\hline Recommended Buffer Width: & $2-4$ feet \\
\hline Priority Index Ranking: & 63 (Moderate) \\
\hline
\end{tabular}

Reason Selected: Will connect to existing sidewalk network Cost: $\$ 34,649$

Funding Source: General Fund,

\begin{tabular}{|cc|}
\hline \multicolumn{2}{|c|}{ (map ref \#75) Moss St East: $12^{\text {th }}$ St to $15^{\text {th }}$ St } \\
\hline Recommended Sidewalk Width & 5 feet \\
\hline Recommended Buffer Width: & $2-4$ feet \\
\hline Priority Index Ranking: & 15 (High) \\
\hline
\end{tabular}

Reason Selected: Will connect to existing sidewalk network

Cost: $\$ 34,595$

Funding Source: General Fund

\begin{tabular}{|cc|}
\hline \multicolumn{2}{|c|}{ (map ref \# 76) $13^{\text {th }}$ St North: Enterprise Blvd to Moss St } \\
\hline Recommended Sidewalk Width & 5 feet \\
\hline Recommended Buffer Width: & $2-4$ feet \\
\hline Priority Index Ranking: & 63 (Moderate) \\
\hline
\end{tabular}

Reason Selected: Will connect to existing sidewalk network

Cost: $\$ 59,124$

Funding Source: General Fund

\begin{tabular}{|cc|}
\hline (map ref \# 77) $13^{\text {th }}$ St South: Moss St to Enterprise Blvd \\
\hline Recommended Sidewalk Width & 5 feet \\
\hline Recommended Buffer Width: & $2-4$ feet \\
\hline Priority Index Ranking: & 63 (Moderate) \\
\hline
\end{tabular}

Reason Selected: Will connect to existing sidewalk network

Cost: $\$ 59,068$

Funding Source: General Fund

\begin{tabular}{|cc|}
\hline (map ref \# 78) $14^{\text {th }}$ St North: Bank St to Enterprise Blvd \\
\hline Recommended Sidewalk Width & 5 feet \\
\hline Recommended Buffer Width: & $2-4$ feet \\
\hline Priority Index Ranking: & 82 (Moderate) \\
\hline
\end{tabular}

Reason Selected: Will connect to existing sidewalk network

Cost: $\$ 24,434$

Funding Source: General Fund 


\begin{tabular}{|rc|}
\hline (map ref \# 79) $14^{\text {th }}$ St South: Bank St to Enterprise Blvd \\
\hline Recommended Sidewalk Width & 5 feet \\
\hline Recommended Buffer Width: & $2-4$ feet \\
\hline Priority Index Ranking: & 82 (Moderate)
\end{tabular}

Reason Selected: Will connect communities that are currently without a pedestrian connection Cost: $\$ 24,326$

Funding Source: General Fund

\begin{tabular}{|cc|}
\hline & (map ref \# 80) $15^{\text {th }}$ St North: Hodges St to Bank St \\
\hline Recommended Sidewalk Width & 5 feet \\
\hline Recommended Buffer Width: & $2-4$ feet \\
\hline Priority Index Ranking: & 75 (Moderate) \\
\hline
\end{tabular}

Reason Selected: Will connect existing sidewalk network

Cost: $\$ 65,936$

Funding Source: General Fund

\begin{tabular}{|cc|}
\hline (map ref \# 81) $15^{\text {th }}$ St South: Hodges St to Bank St \\
\hline Recommended Sidewalk Width & 5 feet \\
\hline Recommended Buffer Width: & $2-4$ feet \\
\hline Priority Index Ranking: & 75 (Moderate) \\
\hline
\end{tabular}

Reason Selected: Will connect existing sidewalk network

Cost: $\$ 66,034$

Funding Source: General Fund

\begin{tabular}{|cc|}
\hline \multicolumn{2}{|c|}{ (map ref \# 82) Bank St West: Gulf St to $12^{\text {th }}$ St } \\
\hline Recommended Sidewalk Width & 5 feet \\
\hline Recommended Buffer Width: & $2-4$ feet \\
\hline Priority Index Ranking: & 9 (High) \\
\hline
\end{tabular}

Reason Selected: Will connect to existing sidewalk network

Cost: $\$ 96,012$

Funding Source: General Fund

\begin{tabular}{|cc|}
\hline \multicolumn{2}{|c|}{ (map ref \# 83) Bank St East: Gulf St to $12^{\text {th }}$ St } \\
\hline Recommended Sidewalk Width & 5 feet \\
\hline Recommended Buffer Width: & $2-4$ feet \\
\hline Priority Index Ranking: & 15 (High) \\
\hline
\end{tabular}

Reason Selected: Will connect to existing sidewalk network

Cost: $\$ 95,745$

Funding Source: General Fund 


\begin{tabular}{|cc|}
\hline (map ref \# 84) $1^{\text {st }}$ Ave West: $12^{\text {th }}$ St to E Prien Lake Rd \\
\hline Recommended Sidewalk Width & 5 feet \\
\hline Recommended Buffer Width: & $2-4$ feet \\
\hline Priority Index Ranking: & 31 (High) \\
\hline
\end{tabular}

Reason Selected: Part of a loop that will connect many parts of the Moss Bluff community; adjacent to post office

Cost: $\$ 134,237$

Funding Source: General Fund

\begin{tabular}{|cc|}
\hline (map ref \# 85) $1^{\text {st }}$ Ave East: $12^{\text {th }}$ St to E Prien Lake Rd \\
\hline Recommended Sidewalk Width & 5 feet \\
\hline Recommended Buffer Width: & $2-4$ feet \\
\hline Priority Index Ranking: & 42 (High) \\
\hline
\end{tabular}

Reason Selected: will connect to existing sidewalk

Cost: $\$ 134,043$

Funding Source: General Fund

\begin{tabular}{|cc|}
\hline \multicolumn{2}{|c|}{ (map ref \# 86) $18^{\text {th }}$ St North: Ryan St to Common St } \\
\hline Recommended Sidewalk Width & 5 feet \\
\hline Recommended Buffer Width: & $2-4$ feet \\
\hline Priority Index Ranking: & 53 (Moderate) \\
\hline
\end{tabular}

Reason Selected: Within $1 / 4$ mile of an elementary school; will connect numerous local roads

Cost: $\$ 35,154$

Funding Source: Safe Routes to School; General Fund

\begin{tabular}{|cc|}
\hline \multicolumn{2}{|c|}{ (map ref \# 87) $18^{\text {th }}$ St South: Ryan St to Common St } \\
\hline Recommended Sidewalk Width & 5 feet \\
\hline Recommended Buffer Width: & $2-4$ feet \\
\hline Priority Index Ranking: & 31 (High) \\
\hline
\end{tabular}

Reason Selected: Within $1 / 4$ mile of an elementary school; will connect to existing sidewalk

Cost: $\$ 35,235$

Funding Source: Safe Routes to School; General Fund

\begin{tabular}{|cc|}
\hline (map ref \# 88) Hwy 14 West 2: Rail Road Tracks to Taylor St \\
\hline Recommended Sidewalk Width & 6 feet \\
\hline Recommended Buffer Width: & $4-6$ feet \\
\hline Priority Index Ranking: & 89 (Moderate) \\
\hline
\end{tabular}

Reason Selected:Important Collector/Arterial roadway

Cost" $\$ 135,270$

Funding Source: General Fund 


\begin{tabular}{|cc|}
\hline (map ref \# 89) E Prien Lake Rd North: Existing Sidewalk to Existing Sidewalk \\
\hline Recommended Sidewalk Width & 6 feet \\
\hline Recommended Buffer Width: & $4-6$ feet \\
\hline Priority Index Ranking: & 95 (Moderate) \\
\hline
\end{tabular}

Reason Selected: Important Collector/Arterial roadway

Cost: $\$ 41,790$

Funding Source: General Fund

\begin{tabular}{|rc|}
\hline (map ref \# 90) E Prien Lake Rd North 2: Kirkman St to Existing Sidewalk \\
\hline Recommended Sidewalk Width & 6 feet \\
\hline Recommended Buffer Width: & $4-6$ feet \\
\hline Priority Index Ranking: & 31 (High) \\
\hline
\end{tabular}

Reason Selected:Important Collector/Arterial roadway

Cost: $\$ 20,850$

Funding Source: General Fund

\begin{tabular}{|cc|}
\hline (map ref \# 91) E Prien Lake Rd North 3: Burton St to $2^{\text {nd }}$ Ave \\
\hline Recommended Sidewalk Width & 6 feet \\
\hline Recommended Buffer Width: & $4-6$ feet \\
\hline Priority Index Ranking: & 42 (High) \\
\hline
\end{tabular}

Reason Selected:Important Collector/Arterial roadway

Cost: $\$ 77,610$

Funding Source: General Fund

\begin{tabular}{|cc|}
\hline \multicolumn{2}{|c|}{ (map ref \# 92) E Prien Lake Rd North 4: $5^{\text {th }}$ Ave to Hwy 14} \\
\hline Recommended Sidewalk Width & 6 feet \\
\hline Recommended Buffer Width: & $4-6$ feet \\
\hline Priority Index Ranking: & 104 (Moderate) \\
\hline
\end{tabular}

Reason Selected: Important Collector/Arterial roadway

Cost: $\$ 82,620$

Funding Source: General Fund

\begin{tabular}{|cc|}
\hline (map ref \# 93) Kirkman St West: Prien Lake Rd to Walters St \\
\hline Recommended Sidewalk Width & 6 feet \\
\hline Recommended Buffer Width: & $4-6$ feet \\
\hline Priority Index Ranking: & 31 (High) \\
\hline
\end{tabular}

Reason Selected: Important Collector/Arterial roadway

Cost: $\$ 160,740$

Funding Source: General Fund 


\begin{tabular}{|cc|}
\hline (map ref \# 94) Kirkman St East: Prien Lake Rd to Madeline St \\
\hline Recommended Sidewalk Width & 6 feet \\
\hline Recommended Buffer Width: & $4-6$ feet \\
\hline Priority Index Ranking: & 15 (High) \\
\hline
\end{tabular}

Reason Selected: Important Collector/Arterial roadway

Cost: $\$ 140,940$

Funding Source: General Fund; SAFETEA-LEA

\begin{tabular}{|cc|}
\hline \multicolumn{2}{|c|}{ (map ref \# 95) Azalea St South: Kirkman St to Louisiana Ave } \\
\hline Recommended Sidewalk Width & 5 feet \\
\hline Recommended Buffer Width: & $2-4$ feet \\
\hline Priority Index Ranking: & 63 (Moderate) \\
\hline
\end{tabular}

Reason Selected: Will connect to an existing sidewalk; will connect different parts of community together

Cost: $\$ 32,500$

Funding Source: General Fund

\begin{tabular}{|cc|}
\hline (map ref \# 96) $5^{\text {th }}$ Ave West: College St to E McNeese St \\
\hline Recommended Sidewalk Width & 5 feet \\
\hline Recommended Buffer Width: & $2-4$ feet \\
\hline Priority Index Ranking: & 132 (Low) \\
\hline
\end{tabular}

Reason Selected: Will connect to an existing sidewalk; will connect different parts of community together

Cost: $\$ 188,418$

Funding Source: General Fund; SAFETEA-LEA

\begin{tabular}{|cc|}
\hline \multicolumn{2}{|c|}{ (map ref \# 97) $5^{\text {th }}$ Ave East: College St to E McNeese St } \\
\hline Recommended Sidewalk Width & 5 feet \\
\hline Recommended Buffer Width: & $2-4$ feet \\
\hline Priority Index Ranking: & 132 (Low) \\
\hline
\end{tabular}

Reason Selected: Will connect to an existing sidewalk; will connect different parts of community together

Cost: $\$ 188,500$

Funding Source: General Fund

\begin{tabular}{|cc|}
\hline (map ref \# 98) Gerstner Memorial Dr East 2: E Prien Lake Rd to McNeese Farm Rd \\
\hline Recommended Sidewalk Width & 6 feet \\
\hline Recommended Buffer Width: & $4-6$ feet \\
\hline Priority Index Ranking: & 89 (Moderate) \\
\hline
\end{tabular}

Reason Selected: Will connect to an existing sidewalk; will connect different parts of community together

Cost: $\$ 137,400$

Funding Source: General Fund; 


\begin{tabular}{|cc|}
\hline \multicolumn{2}{|c|}{ (map ref \# 99) Hwy 14 West: Coolidge St to McNeese St } \\
\hline Recommended Sidewalk Width & 6 feet \\
\hline Recommended Buffer Width: & $4-6$ feet \\
\hline Priority Index Ranking: & 109 (Moderate) \\
\hline
\end{tabular}

Reason Selected: Located adjacent to a school; will connect different parts of community Cost: $\$ 116,038$

Funding Source: General Fund; Safe Routes to School

\begin{tabular}{|cc|}
\hline \multicolumn{2}{|c|}{ (map ref \# 100) Madeline St South: Common S to Kirkman St } \\
\hline Recommended Sidewalk Width & 5 feet \\
\hline Recommended Buffer Width: & $2-4$ feet \\
\hline Priority Index Ranking: & 12 (High) \\
\hline
\end{tabular}

Reason Selected: Will connect to an existing sidewalk; will connect different parts of community together

Cost: $\$ 32,750$

Funding Source: General Fund

\begin{tabular}{|cc|}
\hline \multicolumn{2}{|c|}{ (map ref \# 101) Illinois St South: Brentwood St to E Walton St } \\
\hline Recommended Sidewalk Width & 5 feet \\
\hline Recommended Buffer Width: & $2-4$ feet \\
\hline Priority Index Ranking: & 53 (Moderate) \\
\hline
\end{tabular}

Reason Selected: Will connect to an existing sidewalk; will connect different parts of community together

Cost: $\$ 25,951$

Funding Source: General Fund

\begin{tabular}{|cc|}
\hline (map ref \# 102) Kirkman St West 2: Gayle St to McCall St \\
\hline Recommended Sidewalk Width & 6 feet \\
\hline Recommended Buffer Width: & $4-6$ feet \\
\hline Priority Index Ranking: & 104 (Moderate) \\
\hline
\end{tabular}

Reason Selected: Will connect to an existing sidewalk; will connect different parts of community together

Cost: $\$ 46,410$

Funding Source: General Fund;

\begin{tabular}{|cc|}
\hline \multicolumn{2}{|c|}{ (map ref \# 103) Kirkman St East 2: Walters St to McCall St } \\
\hline Recommended Sidewalk Width & 6 feet \\
\hline Recommended Buffer Width: & $4-6$ feet \\
\hline Priority Index Ranking: & 63 (Moderate) \\
\hline
\end{tabular}

Reason Selected: Will connect to an existing sidewalk; will connect different parts of community together

Cost: $\$ 36,390$

Funding Source: General Fund 


\begin{tabular}{|cc|}
\hline (map ref \# 104) University Dr West: McNeese St to Existing Sidewalk \\
\hline Recommended Sidewalk Width & 5 feet \\
\hline Recommended Buffer Width: & $2-4$ feet \\
\hline Priority Index Ranking: & 89 (Moderate) \\
\hline
\end{tabular}

Reason Selected: Will connect to an existing sidewalk; will connect different parts of community together

Cost: $\$ 11,327$

Funding Source: General Fund;

\begin{tabular}{|cc|}
\hline (map ref \# 105) E McNeese St South: Ryan St to Common St \\
\hline Recommended Sidewalk Width & 6 feet \\
\hline Recommended Buffer Width: & $4-6$ feet \\
\hline Priority Index Ranking: & 117 (Low) \\
\hline
\end{tabular}

Reason Selected: Will connect to an existing sidewalk; will connect different parts of community together

Cost: $\$ 40,787$

Funding Source: General Fund

\begin{tabular}{|cc|}
\hline (map ref \# 106) E McNeese St North: Gerstner Memorial Dr to Existing Sidewalk \\
\hline Recommended Sidewalk Width & 6 feet \\
\hline Recommended Buffer Width: & $4-6$ feet \\
\hline Priority Index Ranking: & 136 (Low) \\
\hline
\end{tabular}

Reason Selected: Will connect to an existing sidewalk; will connect different parts of community

Cost: $\$ 158,924$

Funding Source: General Fund

\section{South Lake Charles}

This area of the City is the most sparsely populated and has the least number of attractors such as parks and schools. It is also the area with the least amount of sidewalks, even on its major roads. This creates a great opportunity for the City to build a sidewalk and bicycle network that fits in with the surrounding neighborhood. While some of the projects suggested in this area are very important and would serve to connect this area with the rest of the city, the long distances necessary to complete a reasonable network make affordability a concern. 
Table 6: South Lake Charles Recommended Sidewalks

\begin{tabular}{|c|c|c|c|c|}
\hline $\begin{array}{l}\text { Map } \\
\text { Ref\# }\end{array}$ & Sidewalk Name & Segment Extents & $\begin{array}{c}\text { Priority } \\
\text { Range }\end{array}$ & $\begin{array}{l}\text { Length } \\
\text { (Feet) }\end{array}$ \\
\hline 107 & W. Sallier St. North Side & Lake St to Ryan St & Moderate & 4,148 \\
\hline 108 & Lake St. East Side & W Sallier St to Country Club Rd & Moderate & 16,074 \\
\hline 109 & Cypress St West Side & Louie St to W 18th St & High & 1,547 \\
\hline 110 & Cypress St East Side & Louie St to W 18th St & High & 1,547 \\
\hline 111 & Hazel St West Side & W 18th St to Penn St & High & 755 \\
\hline 112 & Hazel St East Side & W 18th St to Penn St & High & 755 \\
\hline 113 & W. Prien Lake Rd. South Side 2 & Lake St to Nelson Rd & Low & 5,289 \\
\hline 114 & Holly Hill Rd East Side 2 & W Prien Lake Rd to Existing Sidewalk & Low & 477 \\
\hline 115 & Prien Lake Rd. North Side & Lake St to Ryan St & Moderate & 4,249 \\
\hline 116 & Nelson Rd. East Side & W Prien Lake Rd to W Prien Lake Rd & Low & 1,101 \\
\hline 117 & W. Prien Lake Rd South Side & Nelson Rd to W Prien Lake Rd & Low & 5,226 \\
\hline 118 & W. Prien Lake Rd. East Side & W Prien Lake Rd to W Sale Rd & Low & 3,929 \\
\hline 119 & Burton Ln. West Side & W Prien Lake Rd to W Sale Rd & Low & 3,933 \\
\hline 120 & Burton Ln. East Side & W Prien Lake Rd to W Sale Rd & Low & 3,938 \\
\hline 121 & Nelson Rd. West Side & W Prien Lake Rd to Country Club Rd & Moderate & 9,271 \\
\hline 122 & W. LaGrange St. North Side & Lake St to Creole St & Moderate & 1,384 \\
\hline 123 & W. LaGrange St. South Side & Lake St to Creole St & Moderate & 1,379 \\
\hline 124 & Creole St. West Side & W College St to Julius St & Moderate & 1,094 \\
\hline 125 & Creole St. East Side & W College St to Julius St & Moderate & 1,088 \\
\hline 126 & Holly Hill Rd. West Side & Dumbarton Rd to W Sale Rd & Low & 2,481 \\
\hline 127 & Holly Hill Rd. East Side & Dumbarton Rd to W Sale Rd & Low & 2,472 \\
\hline 128 & W. Sale Rd North Side & W Prien Lake Rd to Existing Sidewalk & Low & 2,281 \\
\hline 129 & W. Sale Rd South Side & W Prien Lake Rd to Existing Sidewalk & Low & 2,483 \\
\hline 130 & W. Sale Rd. North Side 2 & Holly Hill Rd to Ryan St & Moderate & 6,913 \\
\hline 131 & W. Sale Rd. South Side 2 & Holly Hill Rd to Ryan St & Moderate & 7,114 \\
\hline 132 & Ihles Rd. East Side & W Sale Rd to Country Club Rd & Low & 5,442 \\
\hline 133 & Weaver Rd. West Side & W Sale Rd to Country Club Rd & Low & 5,369 \\
\hline 134 & Weaver Rd. East Side & W Sale Rd to Country Club Rd & Low & 5,374 \\
\hline 135 & W. McNeese St. South Side & Weaver Rd to Nelson Rd & Low & 2,612 \\
\hline 136 & W. McNeese St. North Side & Existing Sidewalk to Nelson Rd & Low & 1,441 \\
\hline 137 & W. McNeese St. North 2 & Eileen St to Nelson St & Moderate & 2,108 \\
\hline 138 & W. McNeese St. South Side 2 & Nelson St to Existing Sidewalk & Moderate & 527 \\
\hline 139 & W. McNeese St. South Side 3 & Lake St to Young Ln & Moderate & 406 \\
\hline 140 & W. McNeese St. North Side 3 & Lake St to Ryan St & Low & 5,202 \\
\hline 141 & W. McNeese St South Side 4 & Lake St to Ryan St & Low & 4,263 \\
\hline 142 & Jefferson Dr North Side & Existing Sidewalk to University Dr & Moderate & 685 \\
\hline 143 & University Dr South Side & Lake St to Jefferson Dr & Moderate & 3,229 \\
\hline 144 & Overhill Dr North Side & Central Pkwy to Existing Sidewalk & High & 789 \\
\hline 145 & Overhill Dr South Side & Central Pkwy to Existing Sidewalk & High & 789 \\
\hline 146 & Lisle Peters Rd. North Side & Big Lake Rd to Riverview Ln & Low & 4,512 \\
\hline 147 & Country Club Rd. North Side & Jefferson Dr to Big Lake Rd & Low & 19,260 \\
\hline
\end{tabular}


Figure 18: South Lake Charles Recommended Sidewalks

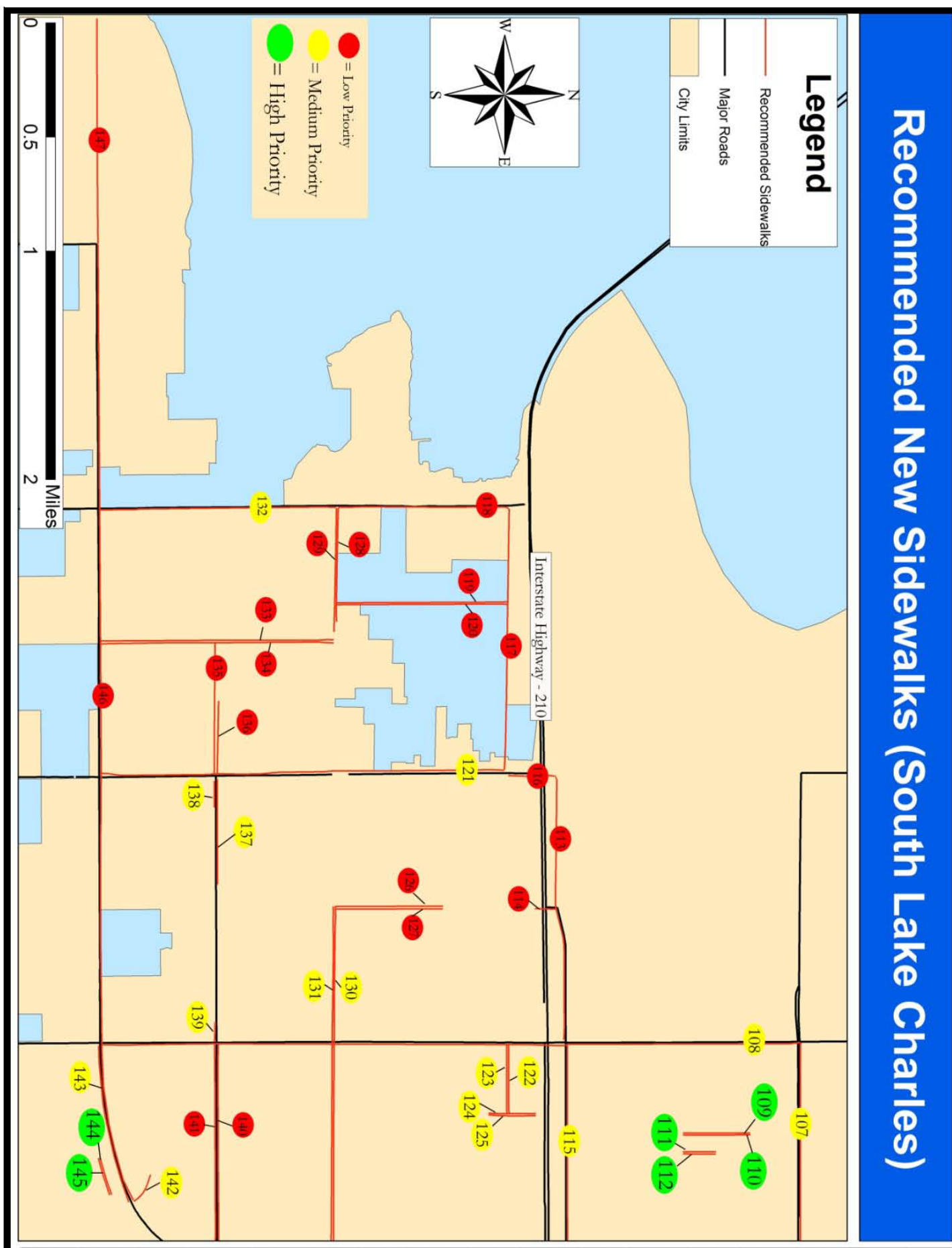

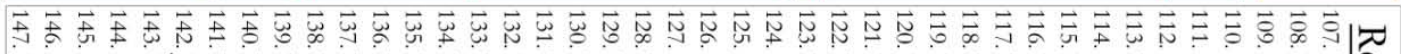

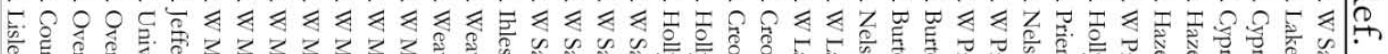

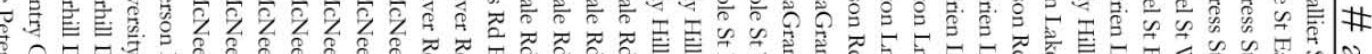

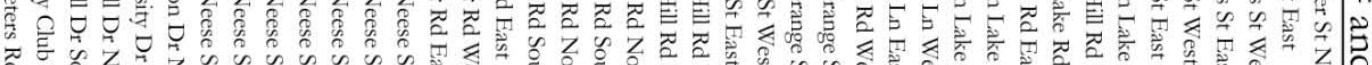

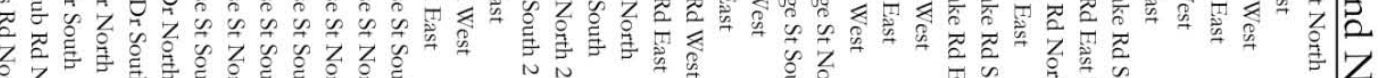

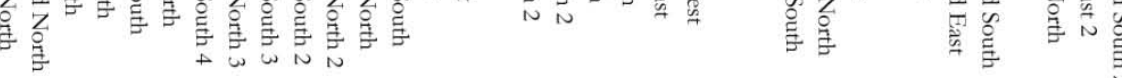




\section{South Lake Charles Area}

\begin{tabular}{|cc|}
\hline \multicolumn{2}{|c|}{ (map ref \# 107) W Sallier St North: Lake St to Ryan St } \\
\hline Recommended Sidewalk Width & 5 feet \\
\hline Recommended Buffer Width: & $4-6$ feet \\
\hline Priority Index Ranking: & 63 (Moderate) \\
\hline
\end{tabular}

Reason Selected: Important Collector/Arterial roadway

Cost: $\$ 103,693$

Funding Source: General Fund

\begin{tabular}{|rc|}
\hline (map ref \# 108) Lake St East: W Sallier St to Country Club Rd \\
\hline Recommended Sidewalk Width & 6 feet \\
\hline Recommended Buffer Width: & $4-6$ feet \\
\hline Priority Index Ranking: & 89 (Moderate) \\
\hline
\end{tabular}

Reason Selected: Important Collector/Arterial roadway

Cost: $\$ 482,208$

Funding Source: General Fund

\begin{tabular}{|cc|}
\hline (map ref \# 109) Cypress St West: Louie St to W $18^{\text {th }}$ St \\
\hline Recommended Sidewalk Width & 6 feet \\
\hline Recommended Buffer Width: & $2-4$ feet \\
\hline Priority Index Ranking: & 31 (High) \\
\hline
\end{tabular}

Reason Selected: Located within 1/4 mile to a school; will connect center of community Cost: $\$ 46,410$

Funding Source: Safe Routes to School; General Fund

\begin{tabular}{|cc|}
\hline \multicolumn{2}{|c|}{ (map ref \# 110) Cypress St East: Louie St to W $18^{\text {th }}$ St } \\
\hline Recommended Sidewalk Width & 6 feet \\
\hline Recommended Buffer Width: & $2-4$ feet \\
\hline Priority Index Ranking: & 31 (High) \\
\hline
\end{tabular}

Reason Selected: Located within $1 / 4$ mile of a school

Cost: $\$ 46,410$

Funding Source: Safe Routes to School; General Fund

\begin{tabular}{|cc|}
\hline \multicolumn{2}{|c|}{ (map ref \# 111) Hazel St West: W $18^{\text {th }}$ St to Penn St } \\
\hline Recommended Sidewalk Width & 6 feet \\
\hline Recommended Buffer Width: & $2-4$ feet \\
\hline Priority Index Ranking: & 42 (High) \\
\hline
\end{tabular}

Reason Selected: Located within 1/4 mile an elementary school; would connect two housing communities

Cost: $\$ 22,650$

Funding Source: General Fund, Safe Routes to School 


\begin{tabular}{|cc|}
\hline \multicolumn{2}{|c|}{ (map ref \# 112) Hazel St West: W $18^{\text {th }}$ St to Penn St } \\
\hline Recommended Sidewalk Width & 6 feet \\
\hline Recommended Buffer Width: & $2-4$ feet \\
\hline Priority Index Ranking: & 42 (High) \\
\hline
\end{tabular}

Reason Selected: Located within 1/4 mile an elementary school; would connect two housing communities

Cost: $\$ 22,650$

Funding Source: General Fund, Safe Routes to School

\begin{tabular}{|cc|}
\hline (map ref \# 113) W Prien Lake Rd South 2: Lake St to Nelson Rd \\
\hline Recommended Sidewalk Width & 6 feet \\
\hline Recommended Buffer Width: & $4-6$ feet \\
\hline Priority Index Ranking: & 132 (Low) \\
\hline
\end{tabular}

Reason Selected: Important Collector/Arterial roadway

Cost: $\$ 158,670$

Funding Source: General Fund

\begin{tabular}{|cc|}
\hline (map ref \# 114) Holly Hill Rd East 2: W Prien Lake Rd to Existing Sidewalk \\
\hline Recommended Sidewalk Width & 5 feet \\
\hline Recommended Buffer Width: & $2-4$ feet \\
\hline Priority Index Ranking: & 124 (Low) \\
\hline
\end{tabular}

Reason Selected: Will connect communities without current pedestrian access

Cost: $\$ 11,918$

Funding Source: General Fund

\begin{tabular}{|cc|}
\hline (map ref \# 115) Prien Lake Rd North: Lake St to Ryan St \\
\hline Recommended Sidewalk Width & 6 feet \\
\hline Recommended Buffer Width: & $4-6$ feet \\
\hline Priority Index Ranking: & 63 (Moderate) \\
\hline
\end{tabular}

Reason Selected: Important Collector/Arterial roadway

Cost: $\$ 127,470$

Funding Source: General Fund

\begin{tabular}{|cc|}
\hline (map ref \# 116) Nelson Rd East: W Prien Lake Rd to W Prien Lake Rd \\
\hline Recommended Sidewalk Width & 6 feet \\
\hline Recommended Buffer Width: & $4-6$ feet \\
\hline Priority Index Ranking: & 117 (Low) \\
\hline
\end{tabular}

Reason Selected: Important Collector/Arterial roadway

Cost: $\$ 33,025$

Funding Source: General Fund 


\begin{tabular}{|cc|}
\hline (map ref \# 117) W Prien Lake Rd South: Nelson Rd to W Prien Lake Rd \\
\hline Recommended Sidewalk Width & 6 feet \\
\hline Recommended Buffer Width: & $4-6$ feet \\
\hline Priority Index Ranking: & 147 (Low) \\
\hline
\end{tabular}

Reason Selected: Important Collector/Arterial roadway

Cost: $\$ 156,779$

Funding Source: General Fund

\begin{tabular}{|cc|}
\hline (map ref \# 118) W Prien Lake Rd East: W Prien Lake Rd to W Sale Rd \\
\hline Recommended Sidewalk Width & 6 feet \\
\hline Recommended Buffer Width: & $4-6$ feet \\
\hline Priority Index Ranking: & 139 (Low) \\
\hline
\end{tabular}

Reason Selected: Important Collector/Arterial roadway

Cost: $\$ 117,877$

Funding Source: General Fund

\begin{tabular}{|cc|}
\hline (map ref \# 119) Burton Ln West: W Prien Lake Rd to W Sale Rd \\
\hline Recommended Sidewalk Width & 5 feet \\
\hline Recommended Buffer Width: & $2-4$ feet \\
\hline Priority Index Ranking: & 142 (Low) \\
\hline
\end{tabular}

Reason Selected: Will connect existing sidewalk network

Cost: $\$ 98,315$

Funding Source: General Fund

\begin{tabular}{|cc|}
\hline (map ref \# 120) Burton Ln East: W Prien Lake Rd to W Sale Rd \\
\hline Recommended Sidewalk Width & 5 feet \\
\hline Recommended Buffer Width: & $2-4$ feet \\
\hline Priority Index Ranking: & 142 (Low) \\
\hline
\end{tabular}

Reason Selected: Will connect the existing sidewalk network

Cost: $\$ 98,435$

Funding Source: General Fund

\begin{tabular}{|rc|}
\hline (map ref \# 121) Nelson Rd West: W Prien Lake Rd to Country Club Rd \\
\hline Recommended Sidewalk Width & 6 feet \\
\hline Recommended Buffer Width: & $4-6$ feet \\
\hline Priority Index Ranking: & 113 (Moderate) \\
\hline
\end{tabular}

Reason Selected:Important Collector/Arterial roadway

Cost: $\$ 278,125$

Funding Source: General Fund 


\begin{tabular}{|cc|}
\hline \multicolumn{2}{|c|}{ (map ref \# 122) W LaGrange St North: Lake St to Creole St } \\
\hline Recommended Sidewalk Width & 5 feet \\
\hline Recommended Buffer Width: & $2-4$ feet \\
\hline Priority Index Ranking: & 109 (Moderate) \\
\hline
\end{tabular}

Reason Selected: Located within $1 / 4$ mile of a school; will connect to a community without any sidewalk access

Cost: $\$ 34,597$

Funding Source: General Fund; Safe Routes to School

\begin{tabular}{|cc|}
\hline (map ref \# 123) W LaGrange St South: Lake St to Creole St \\
\hline Recommended Sidewalk Width & 5 feet \\
\hline Recommended Buffer Width: & $2-4$ feet \\
\hline Priority Index Ranking: & 109 (Moderate) \\
\hline
\end{tabular}

Reason Selected: Located within $1 / 4$ mile of a school; will connect to existing sidewalk Cost: $\$ 34,478$

Funding Source: Safe Routes to School; General Fund

\begin{tabular}{|cc|}
\hline \multicolumn{2}{|c|}{ (map ref \# 124) Creole St West: W College St to Julius St } \\
\hline Recommended Sidewalk Width & 5 feet \\
\hline Recommended Buffer Width: & $2-4$ feet \\
\hline Priority Index Ranking: & 95 (Moderate) \\
\hline
\end{tabular}

Reason Selected: Located within $1 / 4$ mile of a school

Cost: $\$ 27,340$

Funding Source: General Fund

\begin{tabular}{|cc|}
\hline \multicolumn{2}{|c|}{ (map ref \# 125) Creole St West: W College St to Julius St } \\
\hline Recommended Sidewalk Width & 5 feet \\
\hline Recommended Buffer Width: & $2-4$ feet \\
\hline Priority Index Ranking: & 89 (Moderate) \\
\hline
\end{tabular}

Reason Selected: Located within $1 / 4$ mile of a school

Cost: $\$ 27,196$

Funding Source: General Fund

\begin{tabular}{|cc|}
\hline (map ref \# 126) Holly Hill Rd West: Dumbarton Rd to W Sale Rd \\
\hline Recommended Sidewalk Width & 5 feet \\
\hline Recommended Buffer Width: & $2-4$ feet \\
\hline Priority Index Ranking: & 128 (Low) \\
\hline
\end{tabular}

Reason Selected: will connect to existing sidewalk

Cost: $\$ 62,030$

Funding Source: General Fund 


\begin{tabular}{|cc|}
\hline (map ref \# 127) Holly Hill Rd East: Dumbarton Rd to W Sale Rd \\
\hline Recommended Sidewalk Width & 5 feet \\
\hline Recommended Buffer Width: & $2-4$ feet \\
\hline Priority Index Ranking: & 128 (Low) \\
\hline
\end{tabular}

Reason Selected: Will connect with existing sidewalk

Cost: $\$ 61,799$

Funding Source: General Fund

\begin{tabular}{|cc|}
\hline (map ref \# 128) W Sale Rd North: W Prien Lake Rd to Existing Sidewalk \\
\hline Recommended Sidewalk Width & 5 feet \\
\hline Recommended Buffer Width: & $4-6$ feet \\
\hline Priority Index Ranking: & 139 (Low) \\
\hline
\end{tabular}

Reason Selected: Important Artery/Collector Roadway

Cost: $\$ 57,022$

Funding Source: General Fund

\begin{tabular}{|cc|}
\hline (map ref \# 129) W Sale Rd South: W Prien Lake Rd to Existing Sidewalk \\
\hline Recommended Sidewalk Width & 5 feet \\
\hline Recommended Buffer Width: & $4-6$ feet \\
\hline Priority Index Ranking: & 139 (Low) \\
\hline
\end{tabular}

Reason Selected: Important Artery/Collector Roadway

Cost: $\$ 62,083$

Funding Source: General Fund

\begin{tabular}{|cc|}
\hline (map ref \# 130) W Sale Rd North 2: Holly Hill Rd to Ryan St \\
\hline Recommended Sidewalk Width & 5 feet \\
\hline Recommended Buffer Width: & $4-6$ feet \\
\hline Priority Index Ranking: & 75 (Moderate) \\
\hline
\end{tabular}

Reason Selected: Important Artery/Collector Roadway

Cost: $\$ 172,818$

Funding Source: General Fund

\begin{tabular}{|cc|}
\hline (map ref \# 131) W Sale Rd South 2: Holly Hill Rd to Ryan St \\
\hline Recommended Sidewalk Width & 5 feet \\
\hline Recommended Buffer Width: & $4-6$ feet \\
\hline Priority Index Ranking: & 113 (Moderate) \\
\hline
\end{tabular}

Reason Selected: Important Artery/Collector Roadway

Cost: $\$ 177,852$

Funding Source: General Fund 


\begin{tabular}{|cc|}
\hline (map ref \# 132) Ihles Rd East: W Sale Rd to Country Club Rd \\
\hline Recommended Sidewalk Width & 5 feet \\
\hline Recommended Buffer Width: & $4-6$ feet \\
\hline Priority Index Ranking: & 142 (Low) \\
\hline
\end{tabular}

Reason Selected: Important Artery/Collector Roadway

Cost: $\$ 136,061$

Funding Source: General Fund

\begin{tabular}{|cc|}
\hline (map ref \# 133) Weaver Rd West: W Sale Rd to Country Club Rd \\
\hline Recommended Sidewalk Width & 5 feet \\
\hline Recommended Buffer Width: & $4-6$ feet \\
\hline Priority Index Ranking: & 136 (Low) \\
\hline
\end{tabular}

Reason Selected: Located within $1 / 4$ mile of a school

Cost: $\$ 134,232$

Funding Source: General Fund; Safe Routes to School

\begin{tabular}{|cc|}
\hline (map ref \# 134) Weaver Rd East: W Sale Rd to Country Club Rd \\
\hline Recommended Sidewalk Width & 5 feet \\
\hline Recommended Buffer Width: & $4-6$ feet \\
\hline Priority Index Ranking: & 136 (Low) \\
\hline
\end{tabular}

Reason Selected: Located within $1 / 4$ mile of a school

Cost: $\$ 134,349$

Funding Source: General Fund; Safe Routes to School

\begin{tabular}{|cc|}
\hline (map ref \# 135) W McNeese St South: Weaver Rd to Nelson Rd \\
\hline Recommended Sidewalk Width & 6 feet \\
\hline Recommended Buffer Width: & $4-6$ feet \\
\hline Priority Index Ranking: & 128 (Low) \\
\hline
\end{tabular}

Reason Selected: Located within $1 / 4$ mile of a school, will connect to an existing sidewalk; will connect different parts of community together

Cost: $\$ 78,360$

Funding Source: General Fund; Safe Routes to School

\begin{tabular}{|cc|}
\hline (map ref \# 136) W McNeese St North: Existing Sidewalk to Nelson Rd \\
\hline Recommended Sidewalk Width & 6 feet \\
\hline Recommended Buffer Width: & $4-6$ feet \\
\hline Priority Index Ranking: & 117 (Low) \\
\hline
\end{tabular}

Reason Selected: Located within $1 / 4$ mile of a school, will connect to an existing sidewalk; will connect different parts of community together

Cost: $\$ 43,241$

Funding Source: General Fund;Safe Routes to School 


\begin{tabular}{|cc|}
\hline (map ref \# 137) W McNeese St North 2: Eileen St to Nelson Rd \\
\hline Recommended Sidewalk Width & 6 feet \\
\hline Recommended Buffer Width: & $4-6$ feet \\
\hline Priority Index Ranking: & 104 (Moderate) \\
\hline
\end{tabular}

Reason Selected: Located within $1 / 4$ mile of a school, Will connect to an existing sidewalk; will connect different parts of community

Cost: $\$ 63,230$

Funding Source: General Fund; Safe Routes to School

\begin{tabular}{|cc|}
\hline (map ref \# 138) W McNeese St South 2: Nelson Rd to Existing Sidewalk \\
\hline Recommended Sidewalk Width & 6 feet \\
\hline Recommended Buffer Width: & $4-6$ feet \\
\hline Priority Index Ranking: & 82 (Moderate) \\
\hline
\end{tabular}

Reason Selected: Will connect to an existing sidewalk; Important Artery/Collector roadway Cost: $\$ 15,797$

Funding Source: General Fund;

\begin{tabular}{|cc|}
\hline (map ref \# 139) W McNeese St South 3: Lake St to Young Ln \\
\hline Recommended Sidewalk Width & 6 feet \\
\hline Recommended Buffer Width: & $4-6$ feet \\
\hline Priority Index Ranking: & 113 (Moderate) \\
\hline
\end{tabular}

Reason Selected: Will connect to an existing sidewalk; Important Artery/Collector roadway

Cost: $\$ 12,171$

Funding Source: General Fund

\begin{tabular}{|cc|}
\hline \multicolumn{2}{|c|}{ (map ref \# 140) W McNeese St North 3: Lake St to Ryan St } \\
\hline Recommended Sidewalk Width & 6 feet \\
\hline Recommended Buffer Width: & $4-6$ feet \\
\hline Priority Index Ranking: & 127 (Low) \\
\hline
\end{tabular}

Reason Selected: Located adjacent to a school, Important Artery/Collector roadway

Cost: $\$ 156,063$

Funding Source: General Fund; Safe Routes to school

\begin{tabular}{|cc|}
\hline (map ref \# 141) W McNeese St South 4: Lake St to Ryan St \\
\hline Recommended Sidewalk Width & 6 feet \\
\hline Recommended Buffer Width: & $4-6$ feet \\
\hline Priority Index Ranking: & 131 (Low) \\
\hline
\end{tabular}

Reason Selected: Important Artery/Collector roadway, will connect different parts of community Cost: $\$ 127,902$

Funding Source: General Fund 


\begin{tabular}{|cc|}
\hline (map ref \# 142) Jefferson Dr North: Existing Sidewalk to University Dr \\
\hline Recommended Sidewalk Width & 5 feet \\
\hline Recommended Buffer Width: & $2-4$ feet \\
\hline Priority Index Ranking: & 53 (Moderate) \\
\hline
\end{tabular}

Reason Selected: Located within 1/4 mile a school, will connect to an existing sidewalk;

Cost: $\$ 17,125$

Funding Source: General Fund; Safe Routes to School

\begin{tabular}{|cc|}
\hline (map ref \# 143) University Dr South: Lake St to Jefferson Dr \\
\hline Recommended Sidewalk Width & 5 feet \\
\hline Recommended Buffer Width: & $2-4$ feet \\
\hline Priority Index Ranking: & 104 (Moderate) \\
\hline
\end{tabular}

Reason Selected: Located within 1/4 mile a school, will connect to an existing sidewalk;

Cost: $\$ 80,733$

Funding Source: General Fund; Safe Routes to School

\begin{tabular}{|cc|}
\hline (map ref \# 144) Overhill Dr North: Central Pkwy to Existing Sidewalk \\
\hline Recommended Sidewalk Width & 5 feet \\
\hline Recommended Buffer Width: & $2-4$ feet \\
\hline Priority Index Ranking: & 42 (High) \\
\hline
\end{tabular}

Reason Selected: Located within 1/4 mile a school, will connect to an existing sidewalk; will connect different parts of community

Cost: $\$ 19,725$

Funding Source: General Fund; Safe Routes to School

\begin{tabular}{|cc|}
\hline (map ref \# 145) Overhill Dr South: Central Pkwy to Existing Sidewalk \\
\hline Recommended Sidewalk Width & 5 feet \\
\hline Recommended Buffer Width: & $2-4$ feet \\
\hline Priority Index Ranking: & 42 (High) \\
\hline
\end{tabular}

Reason Selected: Located within 1/4 mile a school, will connect to an existing sidewalk; will connect different parts of community together

Cost: $\$ 19,725$

Funding Source: General Fund; Safe Routes to School

\begin{tabular}{|cc|}
\hline (map ref \# 146) Lisle Peters Rd North: Big Lake Rd to Riverview Ln \\
\hline Recommended Sidewalk Width & 5 feet \\
\hline Recommended Buffer Width: & $2-4$ feet \\
\hline Priority Index Ranking: & 142 (Low) \\
\hline
\end{tabular}

Reason Selected: Will connect to an existing sidewalk; will connect different parts of community together

Cost: $\$ 112,798$

Funding Source: General Fund 


\begin{tabular}{|cc|}
\hline (map ref \# 147) Country Club Rd North: Jefferson Dr to Big Lake Rd \\
\hline Recommended Sidewalk Width & 6 feet \\
\hline Recommended Buffer Width: & $4-6$ feet \\
\hline Priority Index Ranking: & 132 (Low) \\
\hline
\end{tabular}

Reason Selected: Located within 1/4 mile a school, will connect different parts of community, Important Artery/Collector roadway

Cost: $\$ 577,791$

Funding Source: General Fund;Safe Routes to School 


\section{Bikeway Network}

Bicyclists can travel further distances at faster speeds than pedestrians so the bikeway network can be larger in scale than the sidewalk network. This new network is meant to serve all level of riders and connect neighborhoods and businesses between the various areas of the city. The projects chosen were a combination of previous planning documents, public input, and existing traffic analysis.

According to the Federal Highway Administration manual "Selecting Roadway Design Treatments to Accommodate Bicycles," there are three primary factors which influence bicycle travel on streets. The three factors are lane widths, traffic speeds, and traffic volumes. Each of these was taken into account when choosing the optimal bicycle network for the City of Lake Charles.

\section{Lane Widths}

Lane widths are critical for allowing enough room for the combined movement of bicycles and automobiles. National standards require a minimum right-hand curb lane width of 14 feet to safely accommodate shared use. There are a few roadways within Lake Charles that already have roadway widths necessary for sharing with bicycles. There are also some roadways that have sufficient width to allow for the four feet minimum required width of bicycle lanes if stripping and signage were provided.

Numerous collectors and arterials throughout Lake Charles have lane widths of 12 feet or more. In the past, concerns about safety and congestion may have prevented engineers from selecting narrower travel lane widths, especially on higher speed, higher volume arterials. Comprehensive new research, however, indicates that the use of travel lanes between 10 feet and 12 feet on urban, suburban and rural arterials and collectors does not negatively impact overall motor vehicle safety or operations. This fact allows for narrowing of lanes on certain roadways in order to accommodate bicycle lanes.

\section{Roadway Speed Limit}

In order to be considered safe for shared roadway use, traffic speeds of $35 \mathrm{mph}$ or less are required. Bicycle lanes can be substituted for shared roadway use if speed conditions exist that are greater than $35 \mathrm{mph}$. Although the minimum bicycle lane width is $4 \mathrm{feet}$, a sliding scale should be developed that takes into account the added buffer needed with increased automobile speed. While some collector roads located within existing communities have low speed limits, some of the main roadways connecting parts of Lake Charles have speed limits of $35 \mathrm{mph}$ or higher.

\section{Average Daily Traffic Volume}

An annual average daily traffic volume of less than 10,000 vehicles is recommended by the FHWA for shared roadway use. Most of the principal arterials in Lake Charles have an annual daily traffic volume of more than 10,000 vehicles and are not recommended for shared use. Collector and local roads are more conducive to shared use because of their lower traffic volumes and lower traveling speeds and should be considered preferable for a designation of a bicycle route network. Because houses and jobs throughout Lake Charles are often separated by well traveled roads with high rate of speeds, these connections should be made with marked bike lanes on roadways where practical. 
Table 7: Lake Charles Recommended Bikeway Network

\begin{tabular}{|c|c|c|c|c|}
\hline $\begin{array}{l}\text { Map } \\
\text { Ref \# }\end{array}$ & Road Name & Segment Extents & $\begin{array}{l}\text { Priority } \\
\text { Categorv }\end{array}$ & $\begin{array}{l}\text { Type of Facility } \\
\text { Recommended }\end{array}$ \\
\hline 1 & Fitzenrieter Rd. & N Prater Rd to N Simmons St & Moderate & Shared Lane \\
\hline 2 & Fitzenrieter Rd. 2 & N Simmons St to Hwy 171 & Moderate & Bike Lane \\
\hline 3 & N. Prater St. & Opelousas St to Fitzenrieter Rd & High & Shared \\
\hline 4 & N. Simmons St. & Fitzenrieter Rd to Opelousas St & High & Bike Lane \\
\hline 5 & N. Goos Blvd. & Opelousas St to Theriot Rd & High & Bike Lane \\
\hline 6 & Moeling St. & N 1st Ave to Hwy 171 & High & Bike Lane \\
\hline 7 & N. 1st Ave. & Moeling St to N Railroad Ave & High & Shared Lane \\
\hline 8 & Opelousas St. & N Enterprise Blvd to Hwy 171 & High & Bike Lane \\
\hline 9 & N. Railroad Ave & N Bilbo St to N 1st Ave & Moderate & Shared Lane \\
\hline 10 & N. Ryan St & N Railroad Ave to W Mill St & Moderate & Bike Lane \\
\hline 11 & N. Kirkman St & N Railroad Ave to I-10 Svc Rd & Low & Shared Lane \\
\hline 12 & South Shattuck & Broad St to Opelousas St & High & Bike Lane \\
\hline 13 & W. Mill St & Veterans Memorial Dr to Goos St & High & Shared Lane \\
\hline 14 & E. Mill St & Goos St to Hwy 171 & Moderate & Shared Lane \\
\hline 15 & Hodges St. & Alamo St to Belden St & High & Shared Lane \\
\hline 16 & Kirkman St. & N Railroad Ave to College St & High & Bike Lane \\
\hline 17 & Kirby St. & Lakeshore Dr to Bord Du Lac & Moderate & Bike Lane \\
\hline 18 & Kirby St 2 & Ryan St to Louisiana Ave & High & Bike Lane \\
\hline 19 & 2nd St. & Louisiana Ave to 3rd Ave & Moderate & Shared Lane \\
\hline 20 & Shell Beach Dr. & Clarence St to Lake St & Low & Bike Lane \\
\hline 21 & Alvin St. & Shell Beach Dr to Dr Debakey Rd & Moderate & Bike Lane \\
\hline 22 & Dr. Debakey Dr. & Lake St to Ryan St & Moderate & Bike Lane \\
\hline 23 & 1st Ave & Broad St to 12 th St & High & Bike Lane \\
\hline 24 & 7th St. & Ryan St to 4th Ave & High & Shared Lane \\
\hline 25 & 11th St. & Ryan St to 4th Ave & High & Shared Lane \\
\hline 26 & Lake St. & Shell Beach Dr to Country Club Rd & Moderate & Bike Lane \\
\hline 27 & 1st Ave 2 & 12th St to E Prien Lake Rd & Moderate & Shared Lane \\
\hline 28 & 14th St. & Enterprise Blvd to Gerstner Mem Hwy & Moderate & Shared Lane \\
\hline 29 & 18th St. & Common St to Gerstner Memorial Dr & High & Shared Lane \\
\hline 30 & Alamo St. & Ryan St to Enterprise Blvd & Moderate & Bike Lane \\
\hline 31 & W Prien Lake Rd. & Lake St to Nelson Rd & Low & Bike Lane \\
\hline 32 & College St. & Lake St to 5th Ave & Low & Bike Lane \\
\hline 33 & E Prien Lake Rd. & Gerstner Memorial Hwy to Corbina Rd & Low & Shared Lane \\
\hline 34 & Nelson Rd. & W Prien Lake Rd to Country Club Rd & Low & Bike Lane \\
\hline 35 & Kirkman St. 2 & College St to E McNeese St & Moderate & Bike Lane \\
\hline 36 & W. Sale Rd. & Ihles Rd to Ryan St & Low & Bike Lane \\
\hline 37 & E. Sale Rd. & Ryan St to Common St & High & Bike Lane \\
\hline 38 & Ryan St. & W Sale Rd to W McNeese St & Moderate & Bike Lane \\
\hline 39 & Common St. & E Sale Rd to McNeese St & Low & Bike Lane \\
\hline 40 & McNeese St. & Nelson Rd to 5th Ave & Moderate & Bike Lane \\
\hline
\end{tabular}




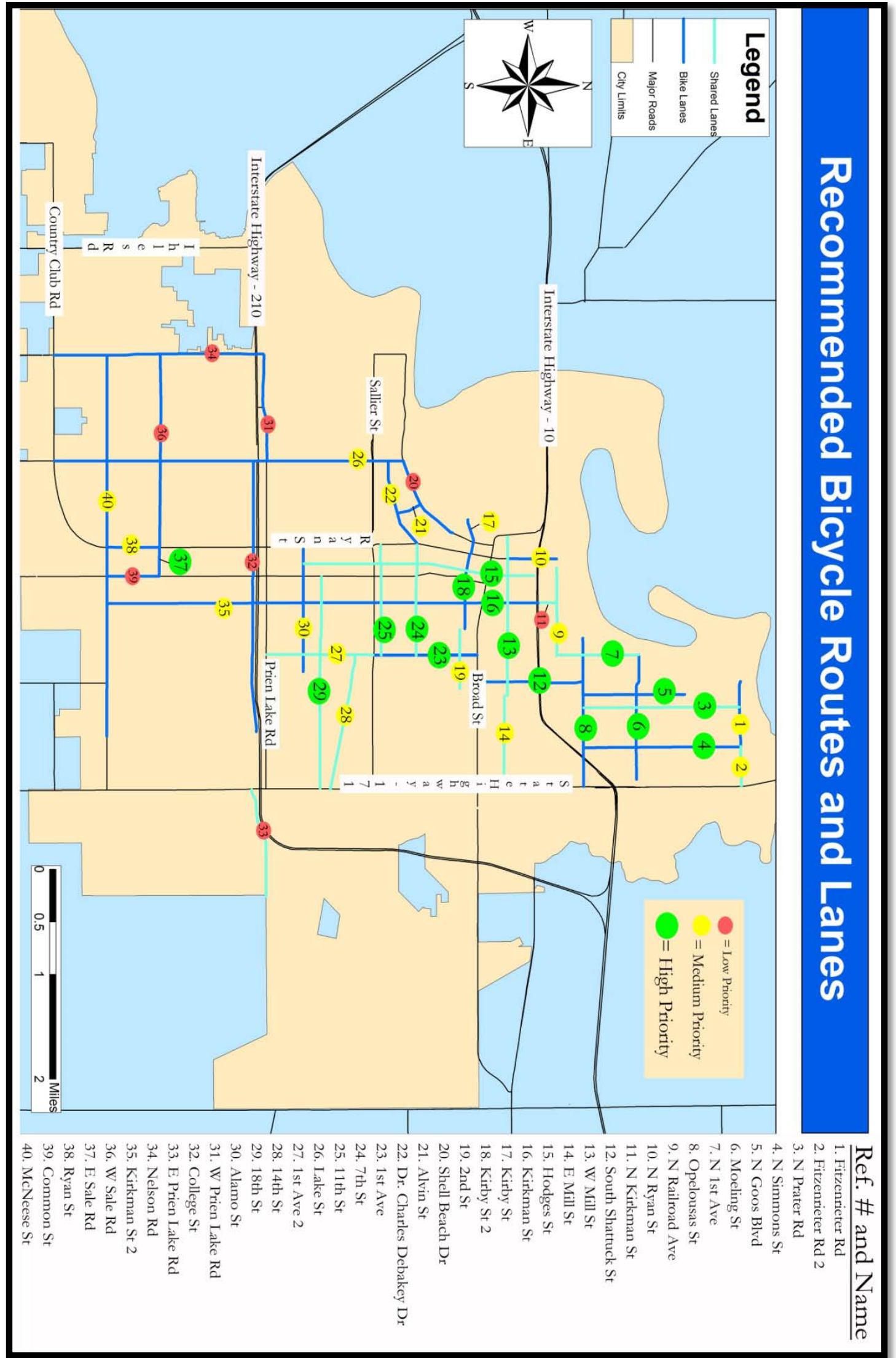


The following table is intended to be used as a quick reference for each suggested segment of the recommended bikeway network.

\begin{tabular}{|c|c|}
\hline \multicolumn{2}{|c|}{ (map reference \#) Street Name: Street Segment } \\
\hline $\begin{array}{r}\text { Traffic Volume: } \\
\text { (annual average daily } \\
\text { traffic AADT) }\end{array}$ & $\begin{array}{c}\text { Under } 3,000 \text { AADT } \\
3,000-10,000 \text { AADT } \\
\text { 10,000-15,000 AADT } \\
\text { over 15,000 AADT }\end{array}$ \\
\hline $\begin{array}{r}\text { Speed Limit: } \\
\text { (average motor } \\
\text { operating speed) }\end{array}$ & $\begin{array}{c}30 \mathrm{mph} \text { or less } \\
30-40 \mathrm{mph} \\
40-50 \mathrm{mph} \\
\text { over } 50 \mathrm{mph}\end{array}$ \\
\hline $\begin{array}{r}\text { Recommended } \\
\text { Facilities: }\end{array}$ & $\begin{array}{l}\text { which type of bicycle } \\
\text { facility is most } \\
\text { appropriate for } \\
\text { existing conditions }\end{array}$ \\
\hline Priority Index Ranking: & $\begin{array}{l}\text { Ranking based upon } \\
\text { scores derived from } \\
\text { attractor and } \\
\text { generator scores, } \\
\text { connectivity, and } \\
\text { affordability added } \\
\text { together }\end{array}$ \\
\hline
\end{tabular}

Improvements Recommended

Discusses the recommended improvements needed, including construction concerns.

\section{Cost}

Estimates costs for recommended facility type.

Funding Source

Identifies potential sources for funding the recommended improvements. 


\begin{tabular}{|rc|}
\hline (map ref \#1) Fitzenreiter Rd: Perkins & Ferry Park to N Simmons St \\
\hline Traffic Volume: & Under 3,000 AADT \\
\hline Speed Limit: & 30 mph or less \\
\hline Recommended Facilities: & Shared Lane \\
\hline Priority Index Ranking: & 24 (Moderate) \\
\hline
\end{tabular}

Improvements Recommended: Signs installed

Cost: Under $\$ 5,000$

Funding Source: SAFETEA-LEAU

\begin{tabular}{|rc|}
\hline (map ref \#2) Fitzenreiter Rd 2: & N Simmons St to Hwy 171 \\
\hline Traffic Volume: & Under 3,000 AADT \\
\hline Speed Limit: & $30-40 \mathrm{mph}$ \\
\hline Recommended Facilities: & 5 foot bike lane \\
\hline Priority Index Ranking: & 20 (Moderate) \\
\hline
\end{tabular}

Improvements Recommended: Narrow existing travel lanes from 15 to 10 feet and stripe bike lanes along with signage

Cost: $\$ 10,000-\$ 20,000$

Source: SAFETEA-LEAU

\begin{tabular}{|cc|}
\hline (map ref \#3) N Prater Rd: Fitzenreiter Rd to Opelousas St \\
\hline Traffic Volume: & Under 3,000 AADT \\
\hline Speed Limit: & 30 mph or less \\
\hline Recommended Facilities: & Shared Lane \\
\hline Priority Index Ranking: & 9 (High) \\
\hline
\end{tabular}

Improvements Recommended: Signs installed

Cost: Under $\$ 10,000$

Funding Source: SAFETEA-LEAU

\begin{tabular}{|rc|}
\hline (map ref \#4) N Simmons St: Fitzenreiter Rd to Opelousas St \\
\hline Traffic Volume: & $3,000-10,000$ AADT \\
\hline Speed Limit: & 30 mph or less \\
\hline Recommended Facilities: & Shared Lane \\
\hline Priority Index Ranking: & 5 (High) \\
\hline
\end{tabular}

Improvements Recommended: Narrow existing travel lanes from 15 to 10 feet and stripe bike lanes along with signage

Cost: $\$ 30,000$

Funding Source: SAFETEA-LEAU 


\begin{tabular}{|c|c|}
\hline \multicolumn{2}{|c|}{ (map ref \#5) N Goos Blvd: Opelousas St to Theriot Rd } \\
\hline Traffic Volume: & Under 3,000 AADT \\
\hline Speed Limit: & $30-40 \mathrm{mph}$ \\
\hline Recommended Facilities: & 5 foot bike lane \\
\hline Priority Index Ranking: & 7 (High) \\
\hline
\end{tabular}

Improvements Recommended: Narrow existing travel lanes from 20 feet to 15 feet and stripe bike lanes along with signage

Cost: $\$ 30,000$

Funding Source: SAFETEA-LEAU

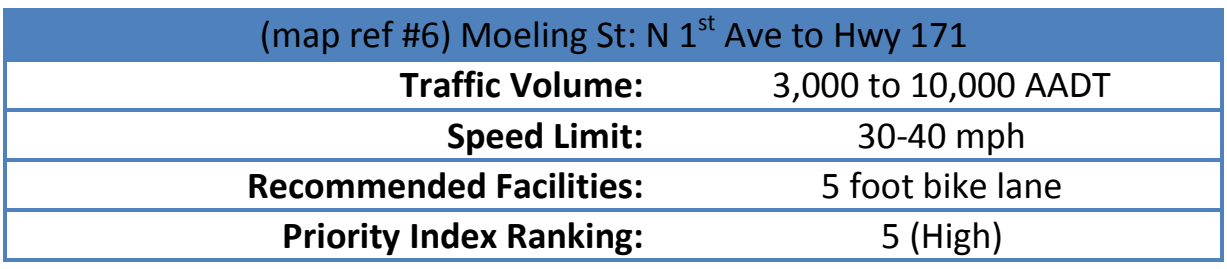

Improvements Recommended: Narrow existing travel lanes to 16 to 11 feet and stripe bike lanes along with signage

Cost: $\$ 35,000$

Funding Source: SAFETEA-LEAU

\begin{tabular}{|cc|}
\hline (map ref \#7) N $1^{\text {st }}$ Ave: Moeling St to N Railroad Ave \\
\hline Traffic Volume: & Under 3,000 AADT \\
\hline Speed Limit: & 30 mph or less \\
\hline Recommended Facilities: & Shared Lane \\
\hline Priority Index Ranking: & 13 (High) \\
\hline
\end{tabular}

Improvements Recommended: Signs installed

Cost: Under $\$ 5,000$

Funding Source: SAFETEA-LEAU

\begin{tabular}{|rc|}
\hline (map ref \#8) Opelousas St: N Enterprise Blvd to Hwy 171 \\
\hline Traffic Volume: & $3,000-10,000$ AADT \\
\hline Speed Limit: & $30-40 \mathrm{mph}$ \\
\hline Recommended Facilities: & 5 foot bike lane \\
\hline Priority Index Ranking: & 9 (High) \\
\hline
\end{tabular}

Improvements Recommended: Narrow existing travel lanes to 15 to 10 feet and stripe bike lanes along with signage

Cost: $\$ 30,000$

Funding Source: SAFETEA-LEAU 


\begin{tabular}{|rc|}
\hline (map ref \#9) N Railroad Ave: $N$ Bilbo St to N $1^{\text {st }}$ Ave \\
\hline Traffic Volume: & Under 3,000 AADT \\
\hline Speed Limit: & 30 mph or less \\
\hline Recommended Facilities: & Shared Lane \\
\hline Priority Index Ranking: & 27 (Moderate) \\
\hline
\end{tabular}

Improvements Recommended: Signs installed

Cost: $\$ 5,000-\$ 10,000$

Funding Source: SAFETEA-LEAU

\begin{tabular}{|cc|}
\hline (map ref \#10) N Ryan St: Jackson St to W Mill St \\
\hline Traffic Volume: & Under 3,000 AADT \\
\hline Speed Limit: & $30-40 \mathrm{mph}$ \\
\hline Recommended Facilities: & 5 foot bike lane \\
\hline Priority Index Ranking: & 24 (Moderate) \\
\hline
\end{tabular}

Improvements Recommended: Narrow existing travel lanes to 16 to 11 feet and stripe bike lanes along with signage

Cost: $\$ 20,000$

Funding Source: SAFETEA-LEAU

\begin{tabular}{|rc|}
\hline (map ref \#11) N Kirkman St: N Railroad Ave to W Mill St \\
\hline Traffic Volume: & Under 3,000 AADT \\
\hline Speed Limit: & 30 mph or less \\
\hline Recommended Facilities: & Shared Lane \\
\hline Priority Index Ranking: & 37 (Low) \\
\hline
\end{tabular}

Improvements Recommended: Signs installed

Cost: Under $\$ 5,000$

Funding Source: SAFETEA-LEAU

\begin{tabular}{|rc|}
\hline \multicolumn{2}{|c|}{ (map ref \#12) S Shattuck: Opelousas St to Broad St } \\
\hline Traffic Volume: & $3,000-10,000$ AADT \\
\hline Speed Limit: & $30-40 \mathrm{mph}$ \\
\hline Recommended Facilities: & 5 foot bike lane \\
\hline Priority Index Ranking: & 13 (High) \\
\hline
\end{tabular}

Improvements Recommended: Narrow existing travel lanes to 16 to 11 feet and stripe bike lanes along with signage

Cost: $\$ 30,000$

Funding Source: SAFETEA-LEAU 


\begin{tabular}{|c|c|}
\hline Traffic Volume: & Under 3,000 AADT \\
\hline Speed Limit: & $30 \mathrm{mph}$ or less \\
\hline Recommended Facilities: & Shared Lane \\
\hline Priority Index Ranking: & 13 (High) \\
\hline
\end{tabular}

Improvements Recommended: Signs installed

Cost: Under $\$ 5,000$

Funding Source: SAFETEA-LEAU

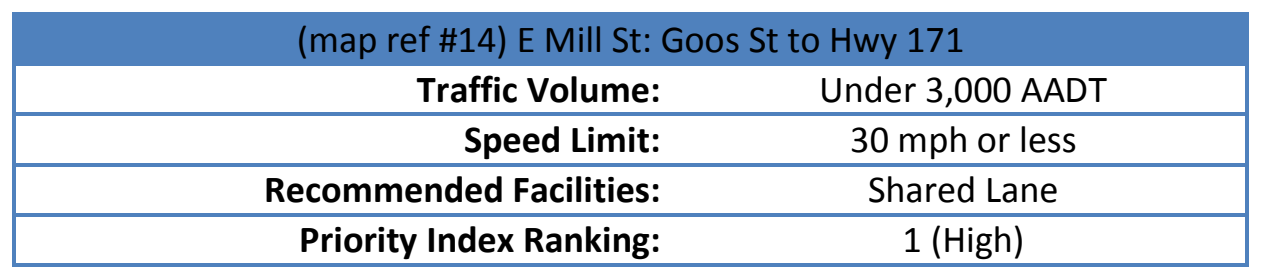

Improvements Recommended: Signs installed

Cost: Under $\$ 5,000$

Funding Source: SAFETEA-LEAU

\begin{tabular}{|rc|}
\hline (map ref \#15) Hodges St: Alamo St to Belden St \\
\hline Traffic Volume: & Under 3,000 AADT \\
\hline Speed Limit: & $30 \mathrm{mph}$ or less \\
\hline Recommended Facilities: & Shared Lane \\
\hline Priority Index Ranking: & 3 (High) \\
\hline
\end{tabular}

Improvements Recommended: Signs installed

Cost: Under $\$ 5,000$

Funding Source: SAFETEA-LEAU

\begin{tabular}{|rc|}
\hline \multicolumn{1}{|c|}{ (map ref \#16) Kirkman St: N Railroad Ave to College St } \\
\hline Traffic Volume: & $3,000-10,000$ AADT \\
\hline Speed Limit: & $30-40 \mathrm{mph}$ \\
\hline Recommended Facilities: & 5 foot bike lane \\
\hline Priority Index Ranking: & 3 (High) \\
\hline
\end{tabular}

Improvements Recommended: Narrow existing travel lanes to 16 to 11 feet and stripe bike lanes along with signage

Cost: $\$ 50,000$

Funding Source: SAFETEA-LEAU 


\begin{tabular}{|rc|}
\hline (map ref \#17) Kirby St: Lakeshore Dr to Bord Du Lac \\
\hline Traffic Volume: & Under 3,000 AADT \\
\hline Speed Limit: & 30 mph or less \\
\hline Recommended Facilities: & 5 foot paved shoulder \\
\hline Priority Index Ranking: & 27 (Moderate) \\
\hline
\end{tabular}

Improvements Recommended: Narrow existing travel lanes to 17 to 12 feet and stripe bike lanes along with signage

Cost: $\$ 10,000$

Funding Source: SAFETEA-LEAU

\begin{tabular}{|rc|}
\hline \multicolumn{1}{|c|}{ (map ref \#18) Kirby St 2: Ryan St to Louisiana Ave } \\
\hline Traffic Volume: & $3,000-10,000$ AADT \\
\hline Speed Limit: & $30-40 \mathrm{mph}$ \\
\hline Recommended Facilities: & 5 foot bike lane \\
\hline Priority Index Ranking: & 12 (High) \\
\hline
\end{tabular}

Improvements Recommended: Take away one of three travel lanes and redesign roadway for inclusion of bike lanes

Cost: $\$ 50,000$

Funding Source: SAFETEA-LEAU

\begin{tabular}{|cc|}
\hline (map ref \#19) $2^{\text {nd }}$ St: Louisiana Ave to $3^{\text {rd }}$ Ave \\
\hline Traffic Volume: & Under 3,000 AADT \\
\hline Speed Limit: & 30 mph or less \\
\hline Recommended Facilities: & Shared Lane \\
\hline Priority Index Ranking: & 20 (Moderate) \\
\hline
\end{tabular}

Improvements Recommended: Signs installed

Cost: Under $\$ 5,000$

Funding Source: SAFETEA-LEAU

\begin{tabular}{|rc|}
\hline (map ref \#20) Shell Beach Dr: Clarence St to Lake St \\
\hline Traffic Volume: & $10,000-15,000$ AADT \\
\hline Speed Limit: & $30-40 \mathrm{mph}$ \\
\hline Recommended Facilities: & 5 foot bike lane \\
\hline Priority Index Ranking: & 39 (Low) \\
\hline
\end{tabular}

Improvements Recommended: Roadway widening of 5 feet on each side

Cost: $\$ 500,000$

Funding Source: SAFETEA-LEAU 


\begin{tabular}{|rc|}
\hline (map ref \#21) Alvin St: Shell Beach Dr to Dr Michael Debakey Dr \\
\hline Traffic Volume: & Under 3,000 AADT \\
\hline Speed Limit: & 30 mph or less \\
\hline Recommended Facilities: & 5 foot bike lane \\
\hline Priority Index Ranking: & 29 (Moderate) \\
\hline
\end{tabular}

Improvements Recommended: Narrow existing travel lanes to 16 to 11 feet and stripe bike lanes along with signage

Cost: $\$ 20,000$

Funding Source: SAFETEA-LEAU

\begin{tabular}{|rc|}
\hline \multicolumn{1}{|c|}{ (map ref \#22) Dr Michael Debakey Dr: Lake St to Ryan St } \\
\hline Traffic Volume: & $3,000-10,000$ AADT \\
\hline Speed Limit: & $30-40 \mathrm{mph}$ \\
\hline Recommended Facilities: & 5 foot bike lane \\
\hline Priority Index Ranking: & 29 (Moderate) \\
\hline
\end{tabular}

Improvements Recommended: Narrow existing travel lanes to 16 to 11 feet and stripe bike lanes along with signage

Cost: $\$ 20,000$

Funding Source: SAFETEA-LEAU

\begin{tabular}{|rc|}
\hline \multicolumn{2}{|c|}{ (map ref \#23) $1^{\text {st }}$ Ave: Broad St to $12^{\text {th }}$ St } \\
\hline Traffic Volume: & Under 3,000 AADT \\
\hline Speed Limit: & $30-40 \mathrm{mph}$ \\
\hline Recommended Facilities: & 5 foot bike lane \\
\hline Priority Index Ranking: & 7 (High) \\
\hline
\end{tabular}

Improvements Recommended: Narrow existing travel lanes from 20 feet to 15 feet and stripe bike lanes along with signage

Cost: $\$ 30,000$

Funding Source: SAFETEA-LEAU

\begin{tabular}{|rc|}
\hline \multicolumn{2}{|c|}{ (map ref \#24) $7^{\text {th }}$ St: Ryan St to $1^{\text {st }}$ Ave } \\
\hline Traffic Volume: & $3,000-10,000$ AADT \\
\hline Speed Limit: & $30-40 \mathrm{mph}$ \\
\hline Recommended Facilities: & 5 foot bike Lane \\
\hline Priority Index Ranking: & 9 (High) \\
\hline
\end{tabular}

Improvements Recommended: Widen roadway to accommodate bike lanes

Cost: $\$ 300,000$

Funding Source: SAFETEA-LEAU 


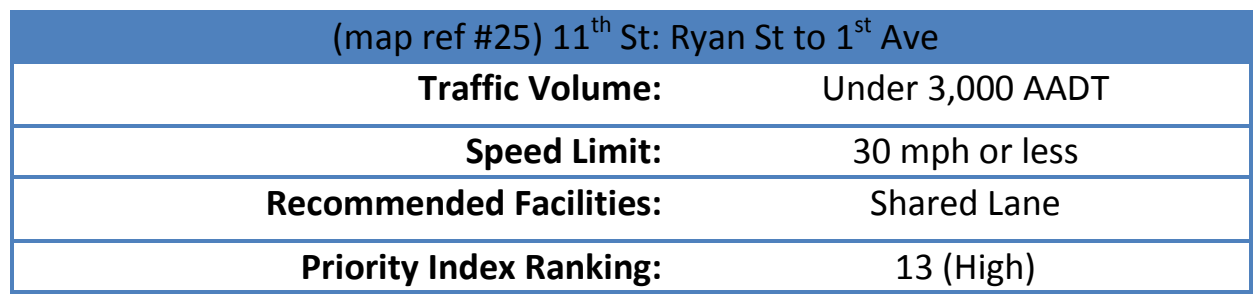

Improvements Recommended: Signs Installed

Cost: Under $\$ 5,000$

Funding Source: SAFETEA-LEAU

\begin{tabular}{|c|c|}
\hline (map ref \#26) Lake St: Shell Be & Country Club Rd \\
\hline Speed Limit: & $30-40 \mathrm{mph}$ \\
\hline Recommended Facilities: & 6 foot bike lane \\
\hline Priority Index Ranking: & 29 (Moderate) \\
\hline
\end{tabular}

Improvements Recommended: Widen roadway by 12 feet to accommodate bike lanes

Cost: Above $\$ 1,000,000$

Funding Source: SAFETEA-LEAU

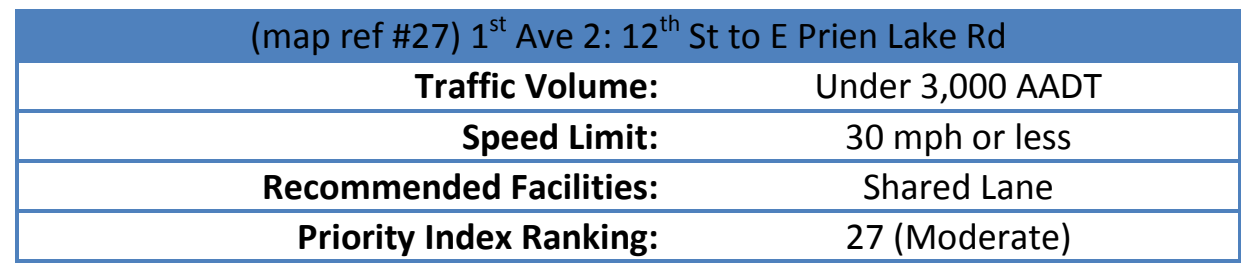

Improvements Recommended: Signs installed

Cost: Under $\$ 5,000$

Funding Source: SAFETEA-LEAU

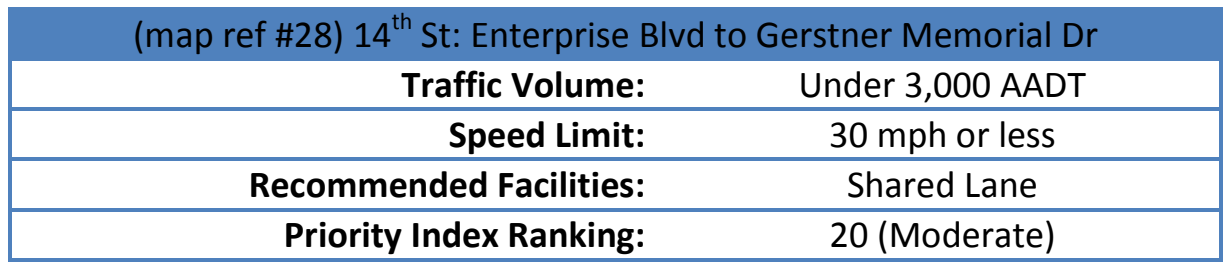

Improvements Recommended: Signs installed

Cost: Under $\$ 5,000$

Funding Source: SAFETEA-LEAU 


\begin{tabular}{|c|c|}
\hline \multicolumn{2}{|c|}{ (map ref \#29) $18^{\text {th }}$ St: Common St to Gerstner Memorial Dr } \\
\hline Traffic Volume: & $3,000-10,000$ AADT \\
\hline Speed Limit: & $30 \mathrm{mph}$ or less \\
\hline Recommended Facilities: & Shared Lane \\
\hline Priority Index Ranking: & 13 (High) \\
\hline
\end{tabular}

Improvements Recommended: Signage installed

Cost: Under $\$ 10,000$

Funding Source: SAFETEA-LEAU

\begin{tabular}{|rc|}
\hline (map ref \#30) Alamo St: Ryan St to Enterprise Blvd \\
\hline Traffic Volume: & $3,000-10,000$ AADT \\
\hline Speed Limit: & $30-40 \mathrm{mph}$ \\
\hline Recommended Facilities: & 5 foot bike lane \\
\hline Priority Index Ranking: & 30 (Moderate) \\
\hline
\end{tabular}

Improvements Recommended: Narrow travel lanes from 15 to 10 feet and stripe bike lanes along with signage

Cost: Under $\$ 5,000$

Funding Source: SAFETEA-LEAU

\begin{tabular}{|rc|}
\hline \multicolumn{2}{|c|}{ (map ref \#31) W Prien Lake Rd: Lake St to Nelson St } \\
\hline Traffic Volume: & 10,000-15,000 AADT \\
\hline Speed Limit: & $30-40 \mathrm{mph}$ \\
\hline Recommended Facilities: & 5 foot bike lane \\
\hline Priority Index Ranking: & 40 (Low) \\
\hline
\end{tabular}

Improvements Recommended: Widen roadway by 8 feet to accommodate bike lanes

Cost: $\$ 500,000$

Funding Source: SAFETEA-LEAU

\begin{tabular}{|rc|}
\hline \multicolumn{2}{|c|}{ (map ref \#32) College St: Lake St to $5^{\text {th }}$ Ave } \\
\hline Traffic Volume: & $10,000-15,000$ AADT \\
\hline Speed Limit: & $30-40 \mathrm{mph}$ \\
\hline Recommended Facilities: & 5 foot bike lane \\
\hline Priority Index Ranking: & 38 (Low) \\
\hline
\end{tabular}

Improvements Recommended: Widen roadway by 12 feet to accommodate bike lanes

Cost: Over $\$ 1,000,000$

Funding Source: SAFETEA-LEAU 


\begin{tabular}{|rc|}
\hline (map ref \#33) E Prien Lake Rd: Gerstner Memorial Dr to Corbina Rd Extension \\
\hline Traffic Volume: & Under 3,000 AADT \\
\hline Speed Limit: & $30-40 \mathrm{mph}$ \\
\hline Recommended Facilities: & Shared Lane \\
\hline Priority Index Ranking: & 40 (Low) \\
\hline
\end{tabular}

Improvements Recommended: Signs installed

Cost: Under $\$ 5,000$

Funding Source: SAFETEA-LEAU

\begin{tabular}{|c|c|}
\hline Traffic Volume: & Above 15,000 AADT \\
\hline Speed Limit: & $30-40 \mathrm{mph}$ \\
\hline Recommended Facilities: & 6 foot bike lane \\
\hline Priority Index Ranking: & 31 (Moderate) \\
\hline
\end{tabular}

Improvements Recommended: Widen roadway by 12 feet to accommodate bike lanes

Cost: Over $\$ 2,000,000$

Funding Source: SAFETEA-LEAU

\begin{tabular}{|rc|}
\hline (map ref \#35) Kirkman St 2: College St to E McNeese St \\
\hline Traffic Volume: & $3,000-10,000$ AADT \\
\hline Speed Limit: & $30-40 \mathrm{mph}$ \\
\hline Recommended Facilities: & 5 foot bike lane \\
\hline Priority Index Ranking: & 20 (Moderate) \\
\hline
\end{tabular}

Improvements Recommended: Widen roadway 10 feet to accommodate bike lanes

Cost: $\$ 500,000$

Funding Source: SAFETEA-LEAU

\begin{tabular}{|rc|}
\hline (map ref \#36) W Sale Rd: Ihles Rd to Ryan St \\
\hline Traffic Volume: & $3,000-10,000$ AADT \\
\hline Speed Limit: & $30-40 \mathrm{mph}$ \\
\hline Recommended Facilities: & 5 foot bike lane \\
\hline Priority Index Ranking: & 37 (Low) \\
\hline
\end{tabular}

Improvements Recommended: Widen roadway 14 feet to accommodate wider travel lanes and bike lanes

Cost: Over $\$ 1,000,000$

Funding Source: SAFETEA-LEAU 


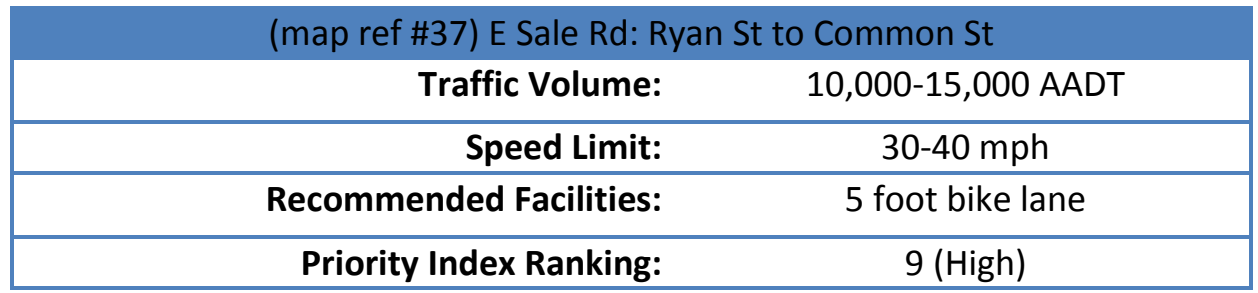

Improvements Recommended: Narrow existing travel lanes from 15 to 10 feet and stripe bike lanes along with signage

Cost: $\$ 10,000$

Funding Source: SAFETEA-LEAU

\begin{tabular}{|rc|}
\hline \multicolumn{1}{|c|}{ (map ref \#38) Ryan St: W Sale Rd to W McNeese St } \\
\hline Traffic Volume: & Over 15,000 AADT \\
\hline Speed Limit: & $30-40 \mathrm{mph}$ \\
\hline Recommended Facilities: & 6 foot bike lane \\
\hline Priority Index Ranking: & 27 (Moderate) \\
\hline
\end{tabular}

Improvements Recommended: Roadway widening of 12 feet to accommodate bike lanes Cost" Over $\$ 500,000$

Funding Source: SAFETEA-LEAU

\begin{tabular}{|cc|}
\hline (map ref \#39) Common St: $E$ Sale Rd to McNeese St \\
\hline Traffic Volume: & $10,000-15,000$ AADT \\
\hline Speed Limit: & $30-40 \mathrm{mph}$ \\
\hline Recommended Facilities: & 5 foot bike lane \\
\hline Priority Index Ranking: & 35 (Low) \\
\hline
\end{tabular}

Improvements Recommended: Roadway widening of 10 feet to accommodate bike lanes Cost: Over $\$ 500,000$

Funding Source: SAFETEA-LEAU

\begin{tabular}{|rc|}
\hline (map ref \#40) McNeese St: Nelson $\mathrm{Rd}$ to ${ }^{\text {th }}$ Ave \\
\hline Traffic Volume: & Over 15,000 AADT \\
\hline Speed Limit: & $30-40 \mathrm{mph}$ \\
\hline Recommended Facilities: & 6 foot bike lane \\
\hline Priority Index Ranking: & 18 (Moderate) \\
\hline
\end{tabular}

Improvements Recommended: Roadway widening of 12 feet to accommodate bike lanes Cost: Over \$2,000,000

Funding Source: SAFETEA-LEAU 


\section{Multi-Use Trails, Connectors, and Staging Areas}

\section{Multi-Use Trails}

For decades, the City of Lake Charles has designed its transportation infrastructure around the automobile, leaving little or no space for bicycles or pedestrians. This can become a problem for those who wish to recreate, or need to travel long distances, while fighting for space on a shared roadway. With that in mind, the creation of grade-separated paths/trails should be developed to serve as connections for non-motorized modes of transportation.

These trails/paths can serve multiple purposes ranging from recreation to commuting to school or work. A total of 5 multi-use paths, which can be used on a citywide level have been identified utilizing aerial photography. The paths chosen are already clear of development, but are located either in roadway medians, next to waterways, or next to railroad tracks. While these obstacles might mean that special precautions be taken when choosing how to design and develop the trail, it does not exclude development of recreational uses.

\section{Connectors/Short-Cuts}

There are a few places throughout the city in which roadways or neighborhoods do not connect to one another. This can create obstacles for bicycles and pedestrians or the need for them to travel unnecessarily long distances to reach their destination. 5 connectors/short-cuts have been identified utilizing aerial photography. These connectors will make it easier for children to walk to school, people to visit friends, or citizens to recreate in their community.

\section{Staging Areas}

People who use the citywide multi-use trails will sometimes have the need to park their cars. Staging areas are necessary in order to provide multi-modal access to the recreational opportunities afforded to them by multi-use trails. These staging areas can be as simple as dirt parking lots or can be elaborate with shade trees, picnic areas, and restrooms. The appropriate level of development should be made dependent on estimated usage and availability of funds.

\begin{tabular}{|c|c|c|}
\hline Name of Trail/Connector & Extents & Length \\
\hline \multirow{10}{*}{$\begin{array}{l}\text { Perkins Ferry Trail } \\
\text { 1st Ave Trail } \\
\text { Lakeshore Canal Trail } \\
\text { Railroad Connector Trail } \\
\text { 5th Ave Trail } \\
\text { N. Railroad Ave Connector } \\
\text { 13th Ave Connector } \\
\text { 5th Ave Circuit Connector } \\
\text { 5th Ave Connector } \\
\text { Parkwav St Connector }\end{array}$} & N. Railroad Ave to Perkins Ferry Park & 2 \\
\hline & Railroad Tracks to 12 th St & 1.75 \\
\hline & Lakeshore Dr to Common St & 0.6 \\
\hline & 1st Ave to 5th Ave & 0.75 \\
\hline & 12th St to McNeese St & 2.5 \\
\hline & N Railroad Ave to N Ryan St & 0.1 \\
\hline & 13th Ave to Gersnter Mem Dr & 0.1 \\
\hline & 5th Ave to 5th Ave & 1 \\
\hline & 5th Ave Circuit to Gersnter Mem Dr & 0.25 \\
\hline & McNeese St to Common St & 0.5 \\
\hline
\end{tabular}




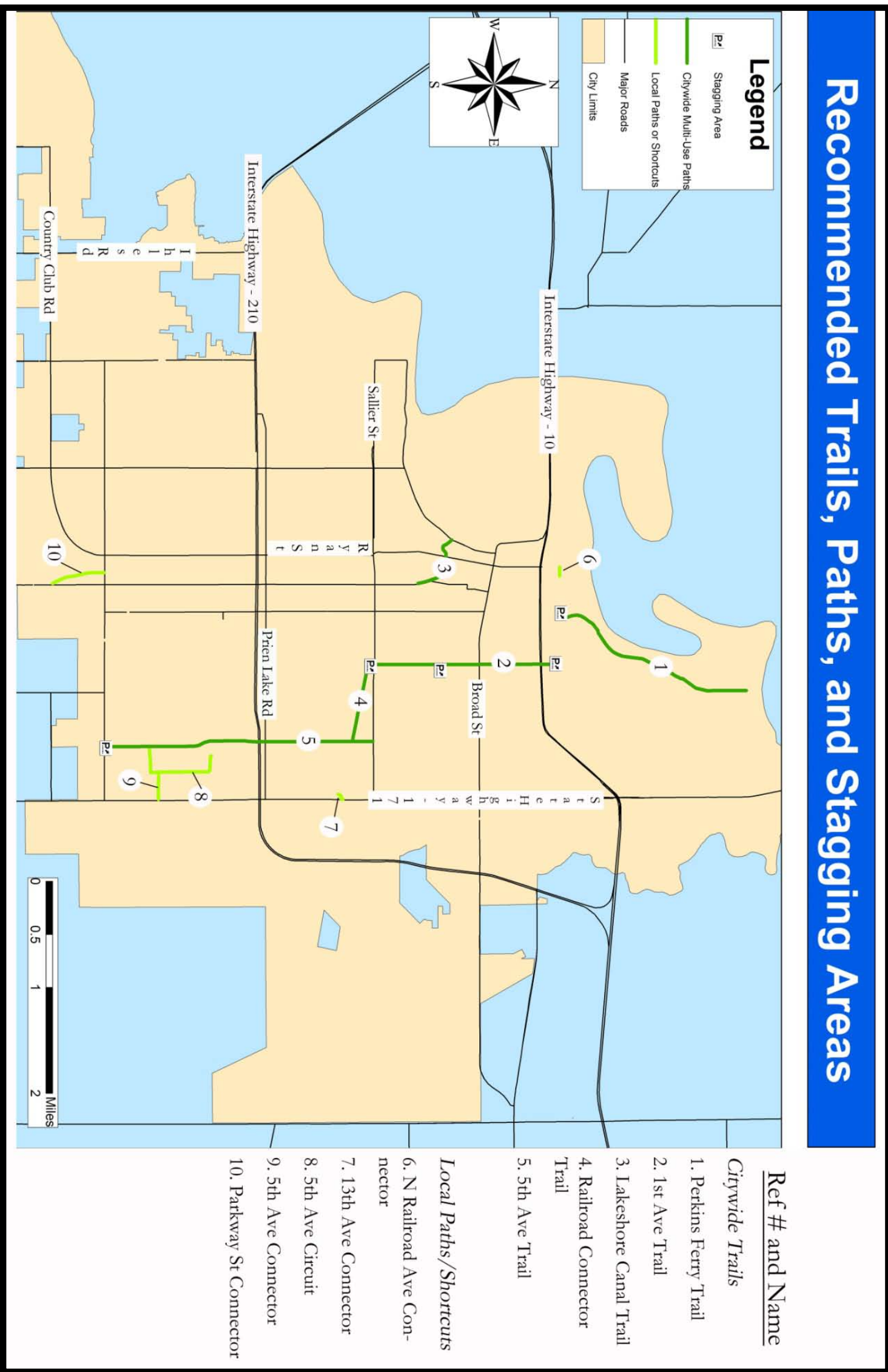




\section{Perkins Ferry Trail}

Located in North Lake Charles, this trail follows alongside and close to the river. It runs north-south for two miles, connecting the downtown area to Perkins Ferry Park. Its main function would be recreational in nature, allowing people to stroll along the shoreline and make their way to the park. Perkins Ferry Park is under consideration for significant improvements such as a boardwalk, viewing areas along the waterfront, and picnic areas.

The right-of-way suggested for this trail is an old abandoned rail line that once was used to serve the industrial businesses along the shoreline. Because railways tend to have generous buffers on each side, the space available for the trail is ample. The state of the area today is slightly on the run-down side, but inclusion of a beautiful recreation trail could help in its revitalization. Any undesirable views of abandoned buildings or security concerns from local businesses could be addressed with fencing or landscaping. One potential concern that must be overcome is a small canal that must be bridged. Potential funding sources

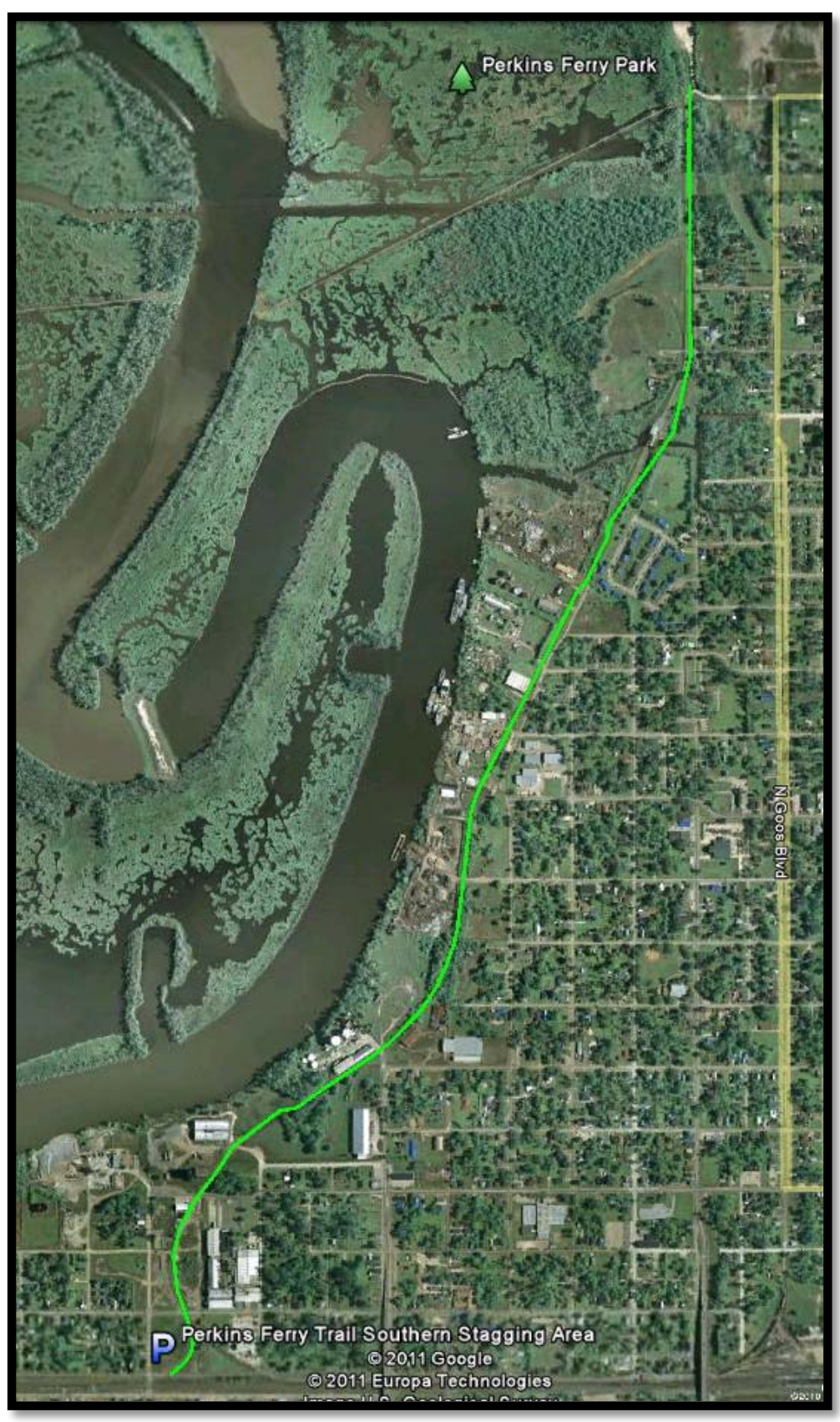
include Rails-to-Trails and the Louisiana's Recreational Trails Program.

An extension of Enterprise Blvd along this right-of-way is included in a redevelopment plan for the North Lake Charles shoreline. The plan calls for a "linear park trail" in the center of the roadway, much the same as has been described here. While the plan has been adopted by the City, no significant steps have been made towards completion of this project because of lack of funding. 
Figure 22: 1st Ave Trail Aerial Photograph

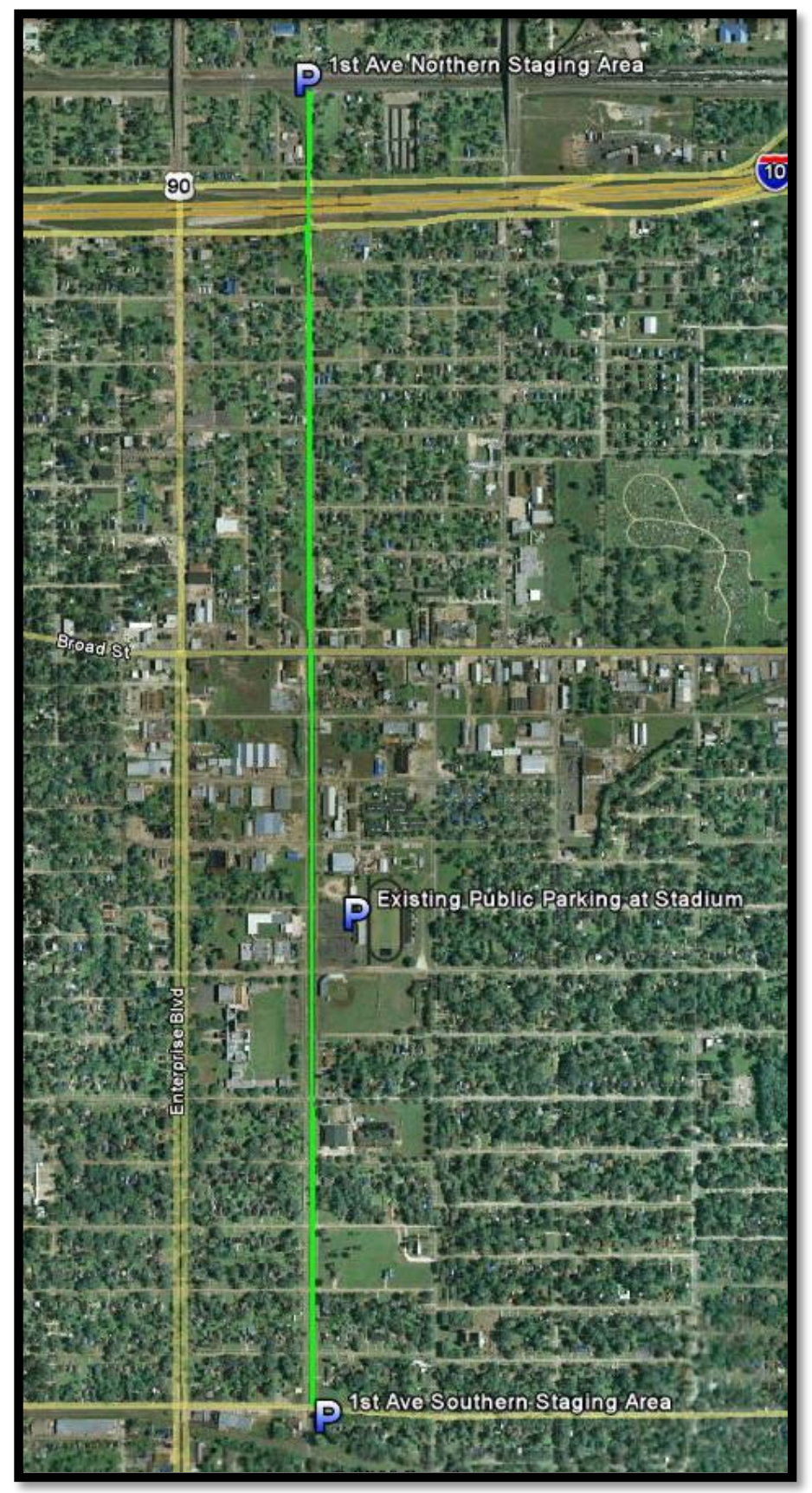

1 st Ave Trail

Serving as the backbone of the proposed trail network in Lake Charles, and already in the initial planning stages, the $1^{\text {st }}$ Ave trail would run north-south for 1.75 miles from the railroad tracks all the way down to $12^{\text {th }}$ St. The project could potentially be broken up into two sections or phases.

The northern section would include the area north of Broad St and the southern section would include the area south of Broad St. The northern section part of the trail would run on the west side of $1^{\text {st }}$ Ave in a right-of-way that is currently in the process of being acquired. Because the City must purchase this land the trail is more likely to take a straight path with few curves or amenities. The southern section would run within the 50 foot median available between each part of the one way traffic flow that is $1^{\text {st }}$ Ave. This large available right-of-way allows the City a chance to make this section of the trail into a "linear park" setting, with amenities such as community gardens, dog runs, children's play structure, or physical fitness stations.

The northern section is mostly residential in nature, while the southern section is a mix of warehouses, schools, and residences. Inclusion of a multi-use trail in this area could serve to increase property values by offering more multi-modal access and recreational opportunities. The area is ripe for development of recreational trails due to its proximity to schools and lack of existing pedestrian and bicycle infrastructure. Potential funding sources for this project include Rails-to-Trails and the Louisiana's Recreational Trails Program. 


\section{Lakeshore Canal Trail}

Located near downtown and connecting the lakefront multi-use path with a proposed bicycle route along $7^{\text {th }}$ Ave, the lakeshore canal trail will serve as a vital non-motorized link for the City. It will run east-west for approximately $6 / 10$ of a mile along the northern section of a canal. The right-of way for this proposed trail has yet to be acquired and is located nears businesses, but the land is only minimally developed in the portion suggested for actual trail use.

The recently completed lakeshore promenade is a local gem and a potential tourist draw. In the very near future lakefront is schedule for much more development and allowing for maximum access to this area is desirable for new businesses and residents alike. This trail will help link the heart of the city with its newly developed lakefront. Potential funding source for this project is the Louisiana Recreational Trail Program.

Figure 23: Lakeshore Canal Trail Aerial Photograph

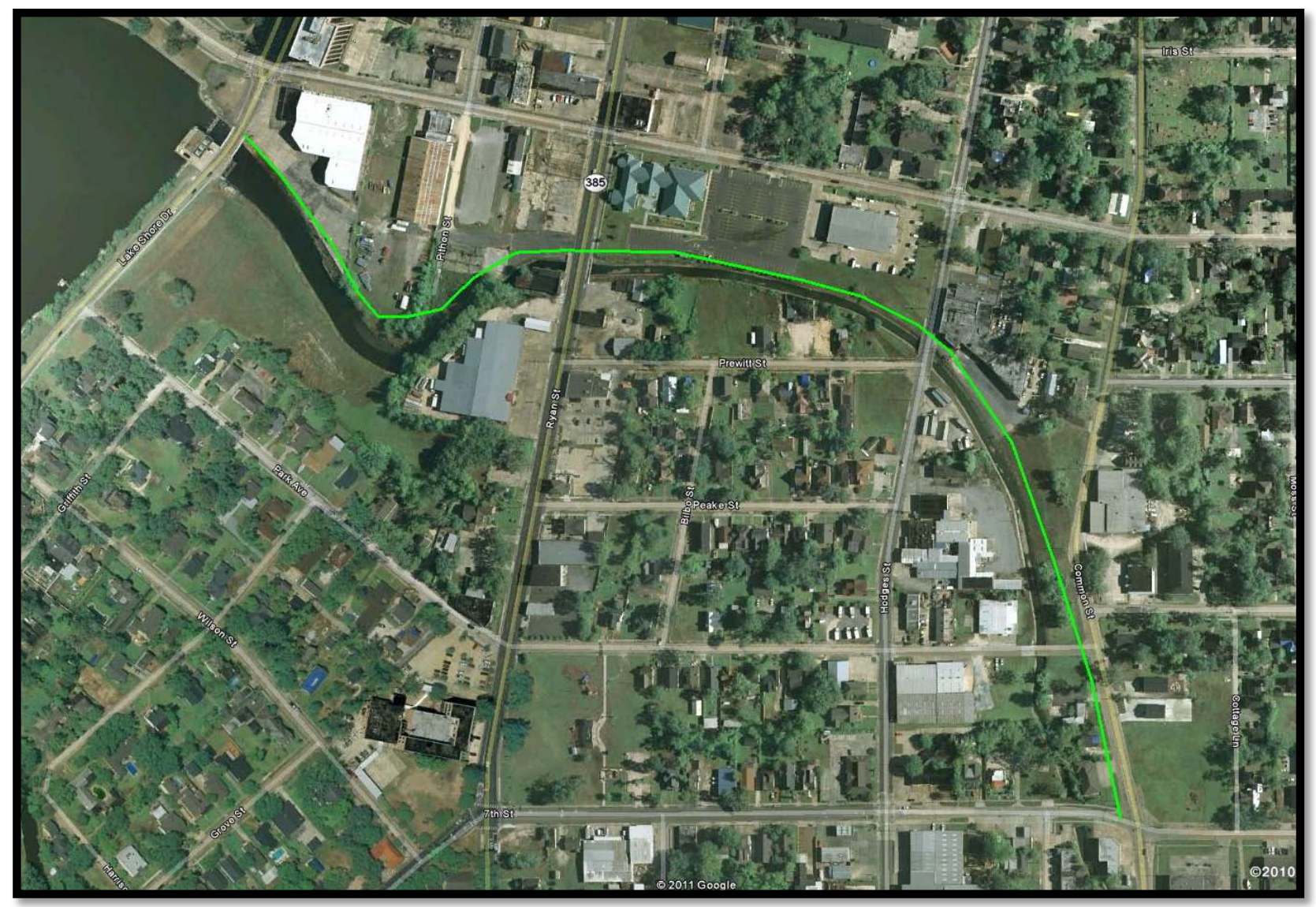




\section{Railroad Connector Trail}

Serving to connect two important north-south trails, the $1^{\text {st }}$ Ave trail and the $5^{\text {th }}$ Ave trail, the railroad connector trail will run east-west for approximately $3 / 4$ of a mile and parallel to an existing and functioning rail line. There seems to be extra right-of-way between the rail line and the property lines of existing houses, but that will have to be researched in more detail in the future.

The right-of-way for constructing this trail will have to be negotiated with the railroad company that is in charge of the current rail line, but numerous examples can be found of this being done. In most cases the railroad will require fencing or some sort of barrier be installed by the city in order to prevent pedestrians from coming in contact with oncoming trains. A pedestrian bridge may have to be constructed to cross the tracks, which could be expensive, but funding for such a project may be available on a state and national level. The inclusion of this connector trail is not vital, but would serve to give a continuous north-south connection for non-motorized modes of transportation from North Lake Charles all the way down to McNeese St.

Figure 24: Railroad Connector Trail Aerial Photograph

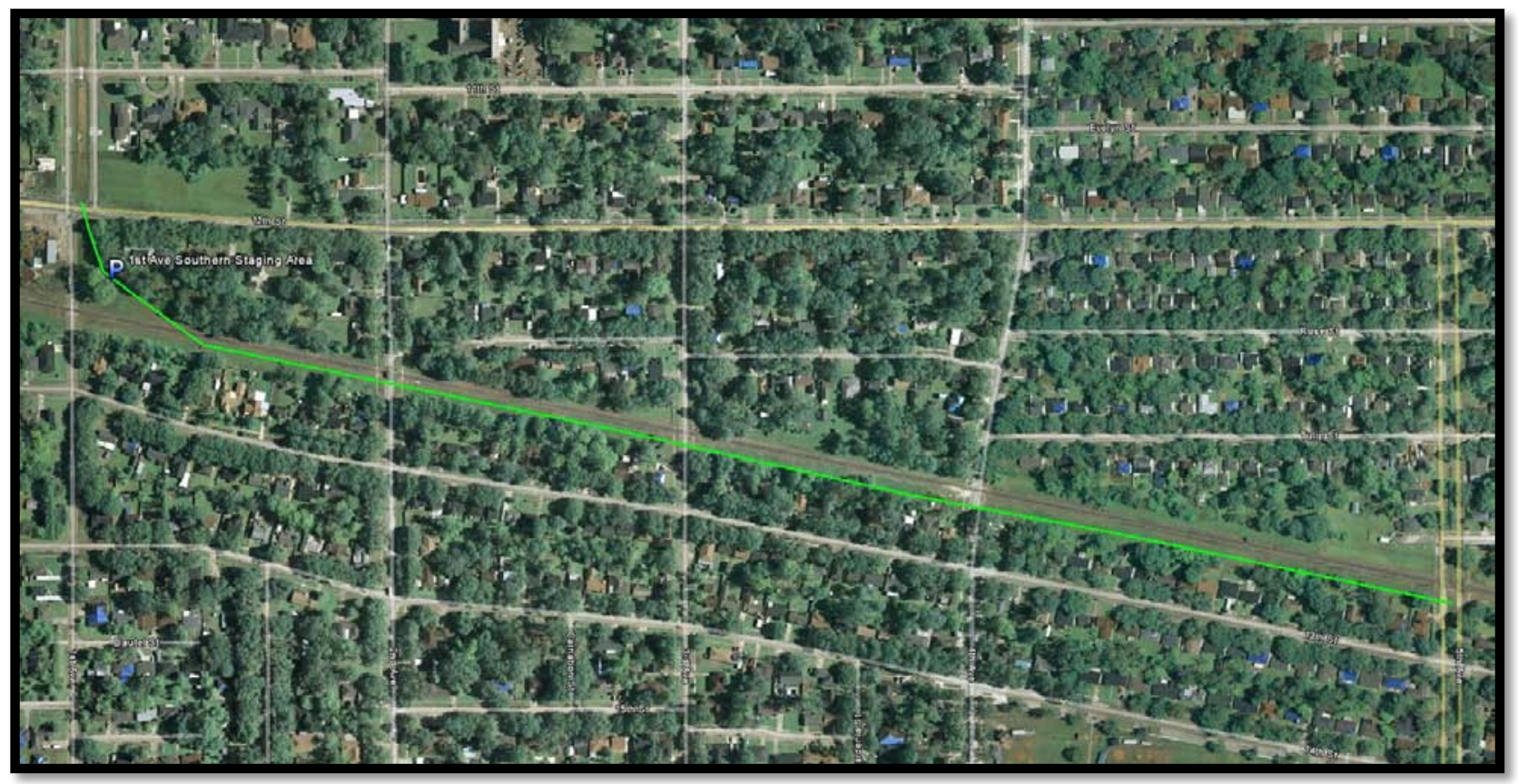




\section{$\underline{5^{\text {th }} \text { Ave Trail }}$}

Linking the center of the city to portions of the south, the $5^{\text {th }}$ Ave trail will run north-south for approximately two miles from $12^{\text {th }}$ Ave to McNeese St. Like the southern section of the $1^{\text {st }}$ Ave trail, the alignment of the $5^{\text {th }}$ Ave trail will be located in the 50 foot wide median located between the one-way traffic-flow of the two roadways that make up $5^{\text {th }}$ Ave.

This proposed trail would run close to a park and two schools, which would allow it to serve both as a commuter trail for children and recreational trail as well. If funding and public support is available, the opportunity to add the same amenities that are recommended on the southern section of the $1^{\text {st }}$ Ave trail can be added to this trail as well. That means that the city can add valuable park space in an area that is currently underutilized.

Figure 25: 5th Ave Trail Aerial Photograph

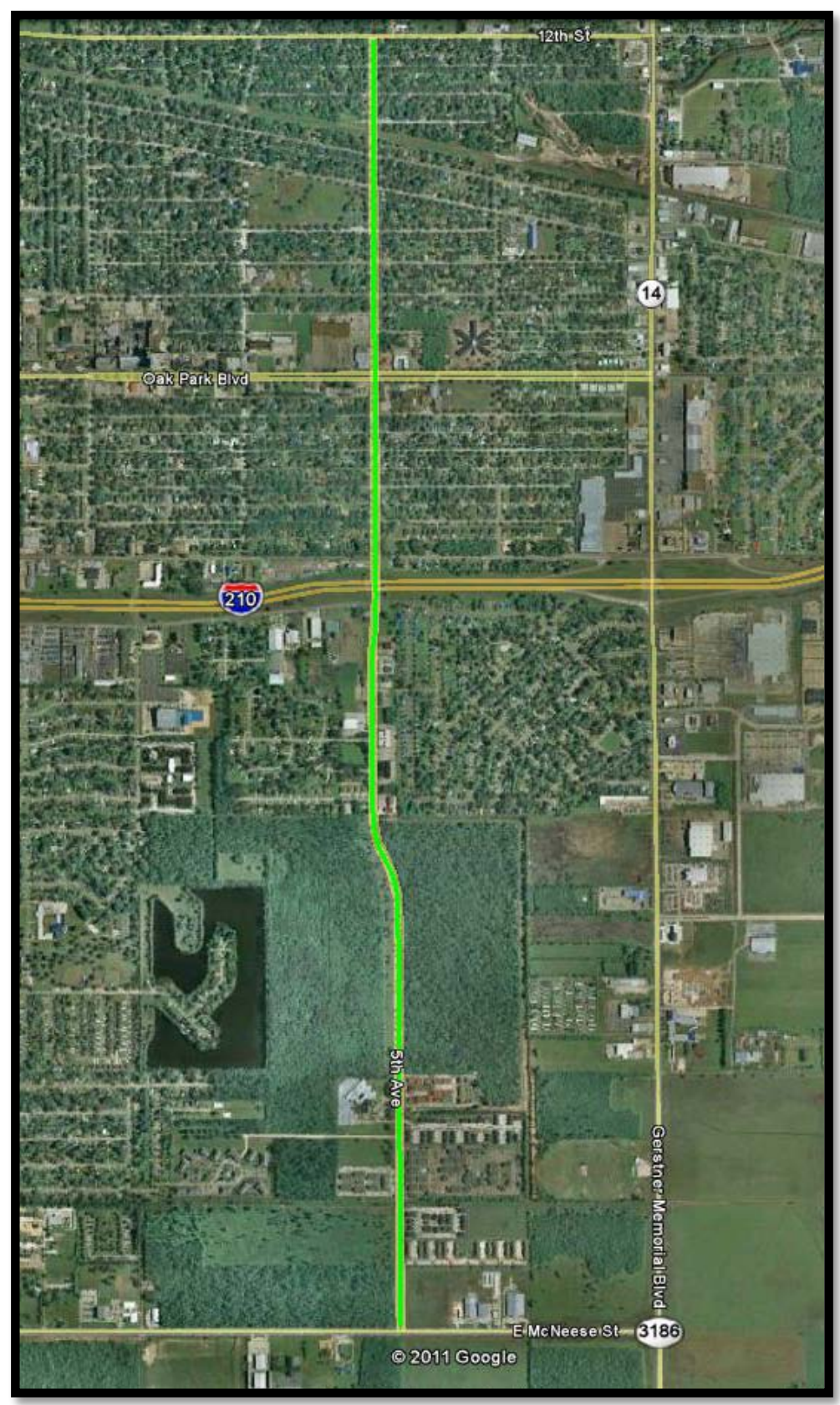




\section{N. Railroad Ave Connector}

This connector will bridge the gap between N. Railroad Ave and N. Ryan St. It will serve as an important piece of the overall network of trail and bikeways. It will run approximately $1 / 10$ of a mile and can be made up of cheaper materials such as crushed rock or cinder.

Figure 26: N. Railroad Ave Connector Aerial Photograph

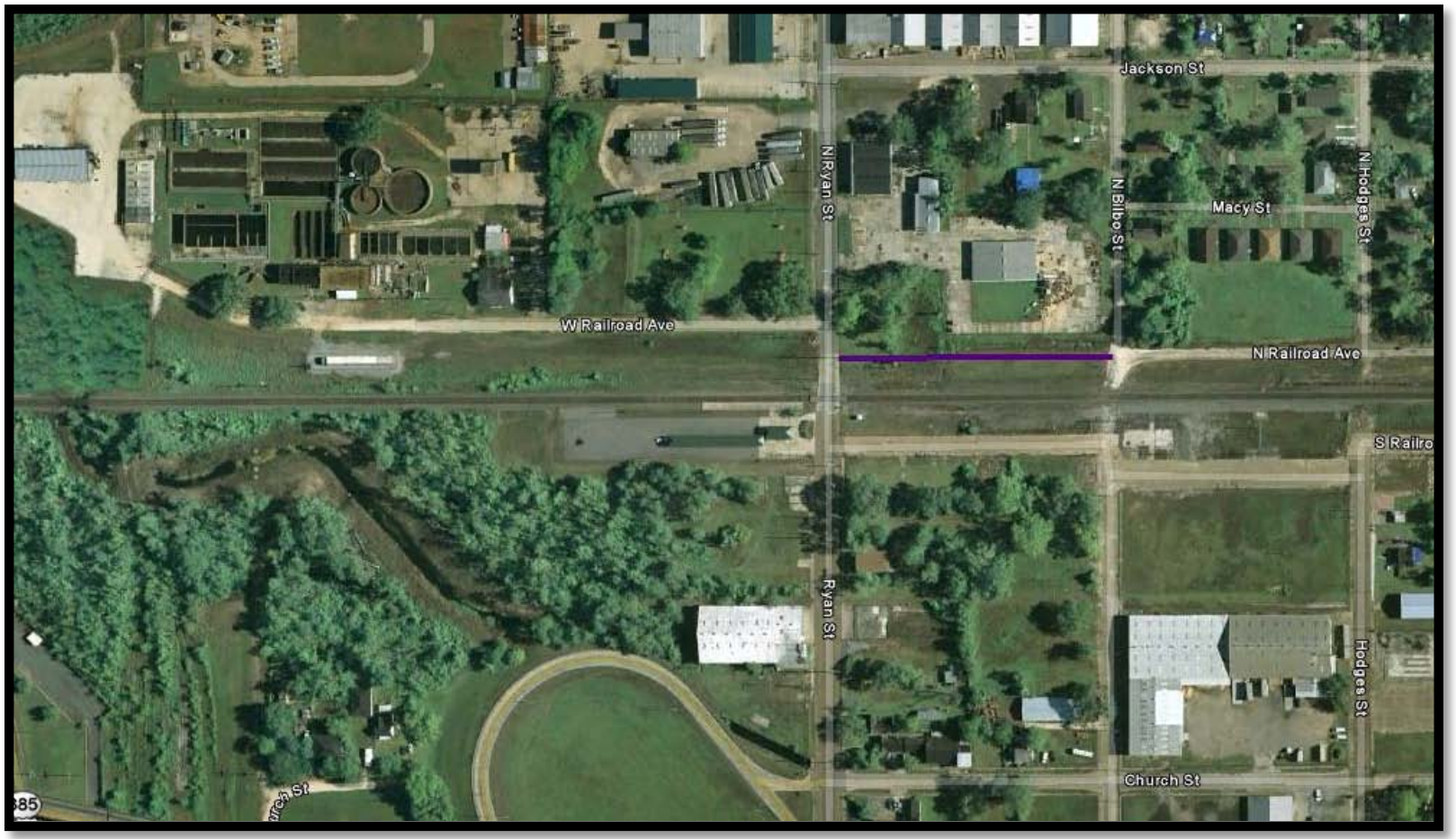

\section{$13^{\text {th }}$ Ave Connector}

This connector is needed as a result of a neighborhood development that lacks connectivity to the adjacent major roadway. Currently, people would have to walk or ride an extra $1 / 2$ mile or so if they travel on $13^{\text {th }}$ Ave and their destination is on or close to Gerstner Memorial Dr. This distance is a huge barrier for many citizens. This short-cut would run only $1 / 10$ of a mile, but would save significant time.

Figure 27: 13th Ave Connector Aerial Photograph

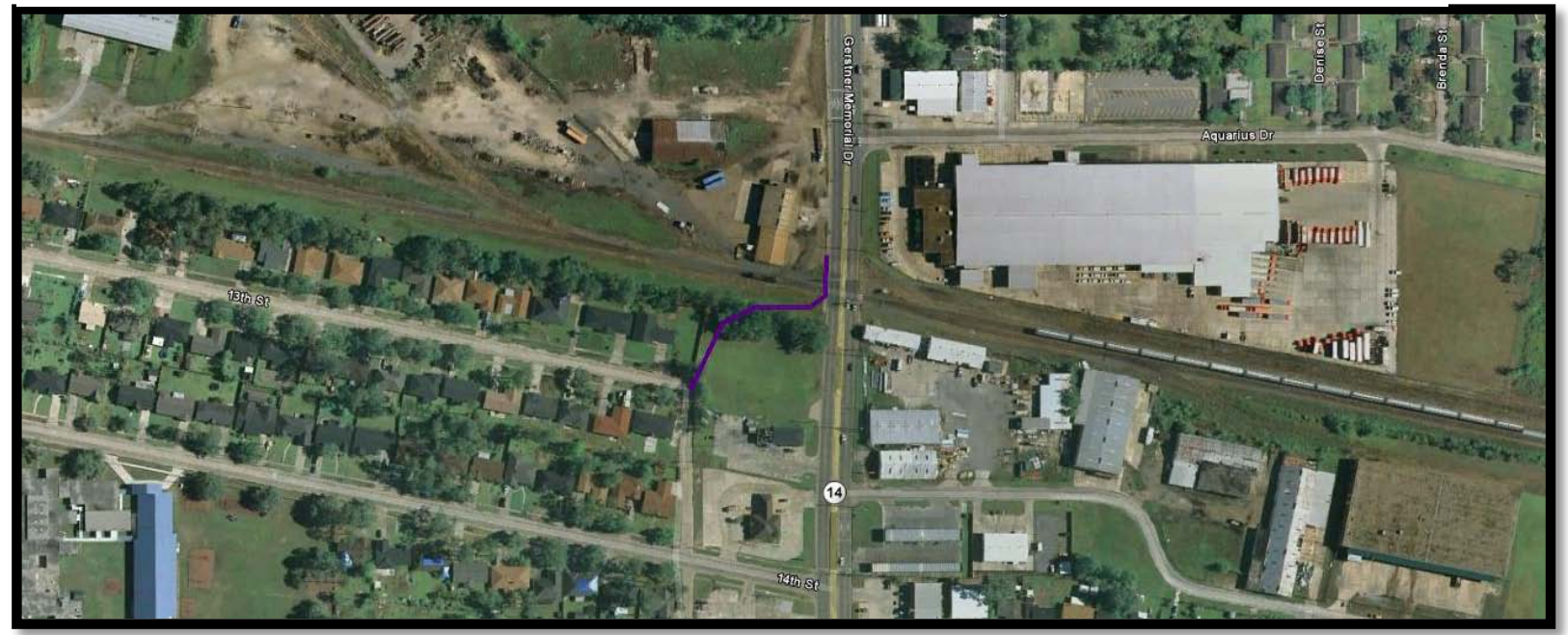




\section{$5^{\text {th }}$ Ave Circuit Connector}

This connector is needed as a result of a neighborhood development that lacks pedestrian connectivity to the adjacent major roadway. A housing development is "as the crow flies" close to an elementary school, but there is not direct access for children to walk and they must be driven by way of roadways; turning the trip that on foot would be only from a few thousand feet into miles in a car. This connector would run approximately one mile and could serve as a link between five housing developments and would also allow local residents to have a place to recreate.

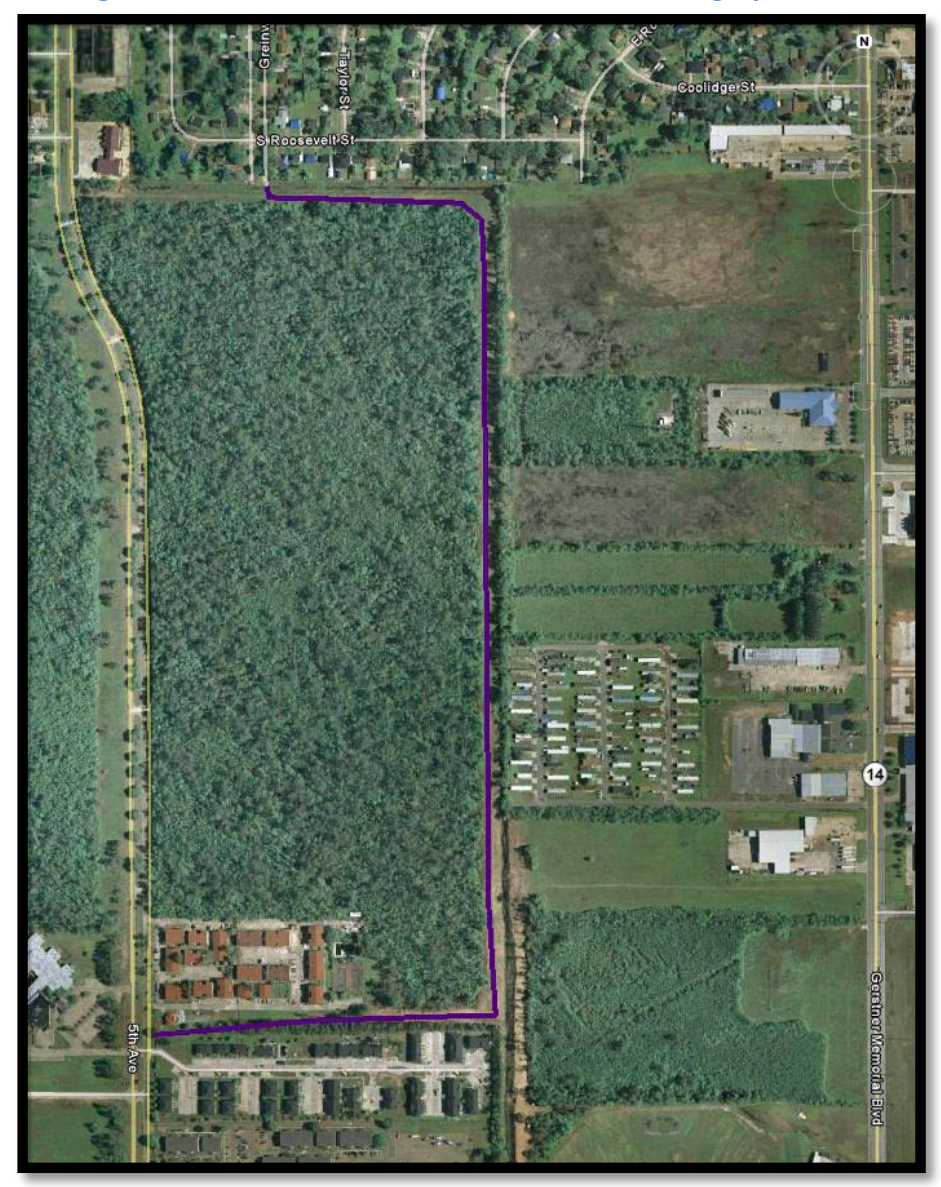

Figure 29: 5th Ave Connector

\section{$\underline{5 \text { th Ave Connector }}$}

This connector would be constructed as an addition to the $5^{\text {th }}$ Ave Circuit Connector and would allow people to make their way to Gerstner Memorial Dr directly and for children to walk safely to Fairview Elementary. This short path of only $1 / 4$ mile could add significantly to the amount of children who walk to school. The materials used for this could be on the cheaper side and could range from crushed rock to cinder.

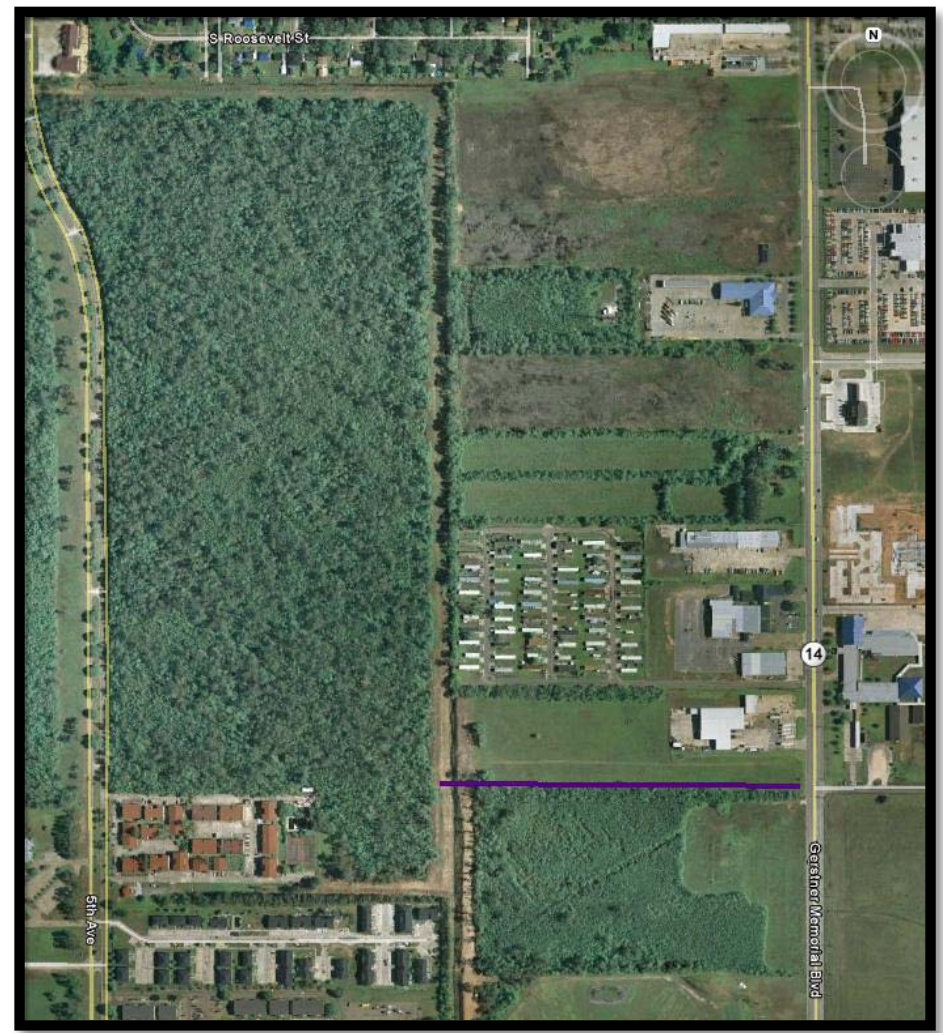




\section{Parkway St. Connector}

This local connector is as much of a recreational trail as a short-cut. It would cut the distance that people have to walk or bike between McNeese St and portions in south Common St. It would run parallel and alongside a canal for approximately $1 / 2$ mile. There are currently no sidewalks on Parkway St and this connector could substitute as a much cheaper option than the need to build them.

Figure 30: Parkway St Connector Aerial Photograph

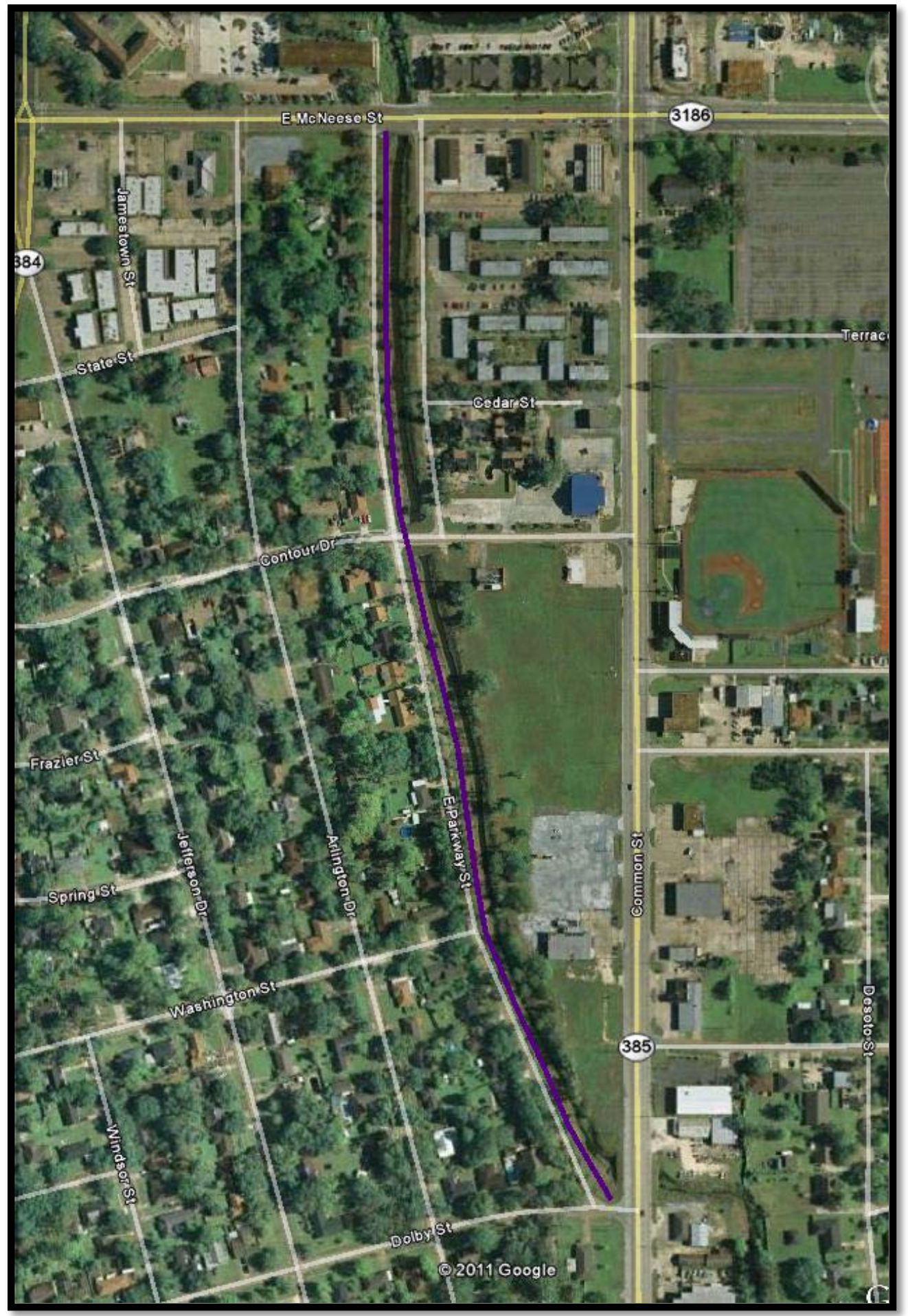




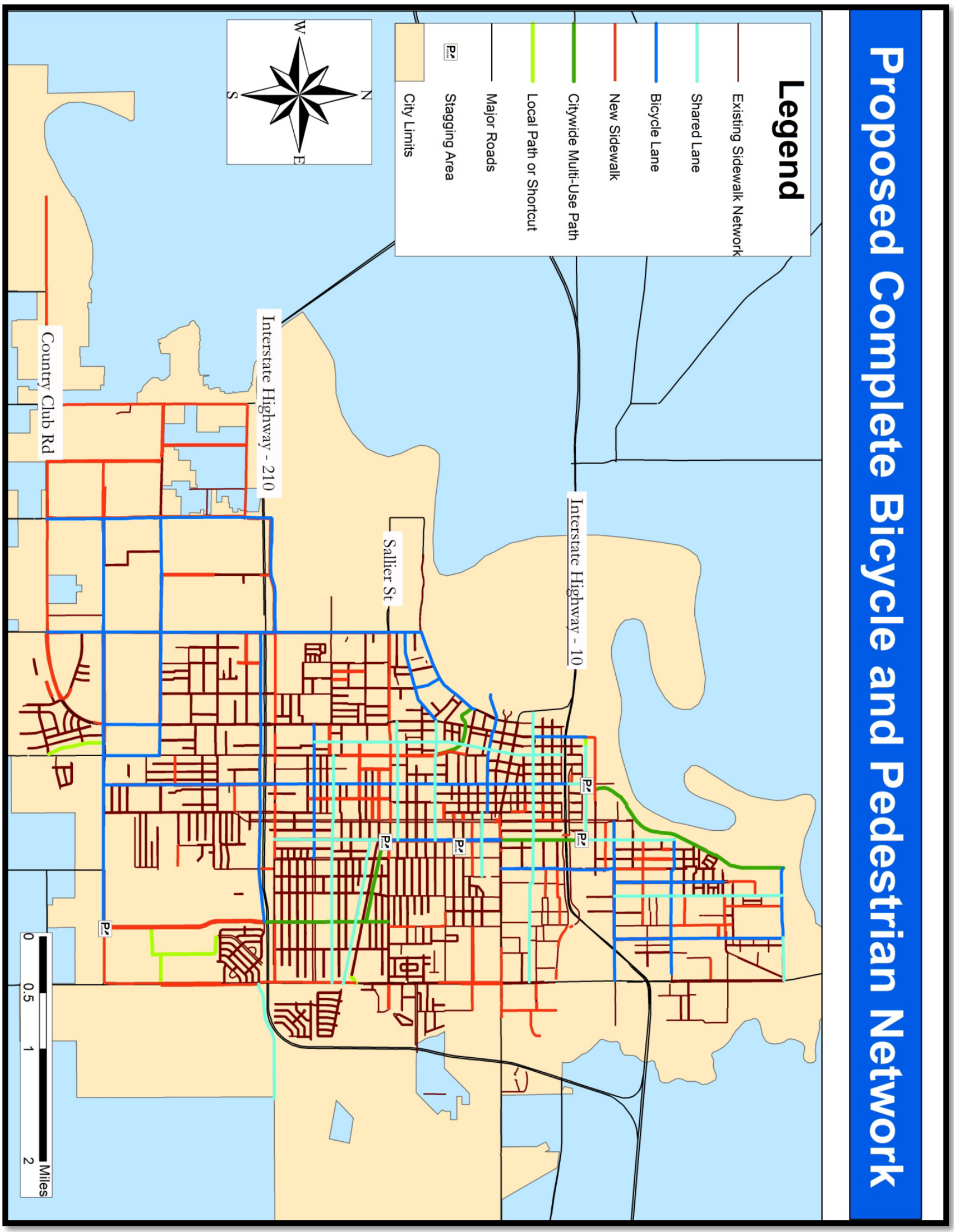




\section{Chapter 7: Implementation Plan}

\section{Steps for Implementing Projects}

After sidewalk projects are identified and ranked, the following steps are proposed to design and implement projects

- $\quad$ Field Verification: Field verification should include a review of existing conditions (such as available right-of-way, adjacent land uses, and pedestrian volumes) and identifying potential design constraints (such at locations of utilities). Defining the extent of a particular project should be made by considering the requests of citizens for sidewalks on specific streets connecting to the project area. It may also be appropriate to combine sidewalk projects with street crossing improvement projects.

- Design Improvements: Appropriate sidewalk improvements should be designed after projects have gone through the field verification process. This includes developing engineering plans and detailed estimates of the cost to construct. The level of improvement should be consistent with the level of pedestrian or bicycle activity.

- Deliver Project: The final step of the implementation program process will be to construct the new improvement project.

\section{Funding}

Improvement projects will be funded either as stand-alone projects that specifically target pedestrian or bicyclist improvements or as part of a larger capital improvement project. In addition to stand-alone alternate modes projects the City of Lake Charles, as a matter of practice, should incorporate alternate mode elements into most capital improvement projects. Examples of projects where bicycles and pedestrian support should be include are roadway reconstruction, widening, and extensions; bridge rehabilitation and replacement; streetscape improvements; neighborhood traffic calming projects; and intersection improvements. Alternate mode elements that are considered include street lighting; sidewalk construction and repair; curb ramps; crosswalks; signalized crossings; and on-street bike lanes.

\section{Sources}

There are a few reliable resources which can be accessed to help fund bicycle and pedestrian improvements. Which funding source is best depends on the type of project proposed. The source of funding generally consists of local, state, and federal funds as outlined below.

\section{Safe Routes to School}

Safe Routes to School is the most well-known and most well funded funding source for sidewalk expansion. This program was created during the past decade with the goal of increasing safety and 
accessibility for children walking or biking to school. This program has been very successful in many cases and has been used by other local cities such as Vinton, lowa, and Calcasieu Parish.

\section{Local Road Safety Improvement Program}

The Local Road Safety Improvement Program is conducted through the state that offers small amounts of money usually around $\$ 10,000$ for improvements to intersections and signage. While this program will not be responsible for funding infrastructure, it can be included into a mix of funding opportunities that increases the safety and visibility of pedestrian crossings.

\section{The Recreational Trails Program}

The Recreational Trails Program (RTP) is a program of the FHWA administered through the state of Louisiana's Department of Culture Recreation and Tourism. In 2010 there was over 1.3 million dollars available for trail grants. Lafayette Parish has been awarded this grant on numerous occasions as part of their Acadiana Trails network. This program will be useful in planning and development of multi-use recreational trails throughout the City of Lake Charles.

\section{$\underline{\text { Rails to Trails }}$}

"Rails to Trails" offers funding and support opportunities for acquisition and conversion of abandoned rail lines into recreational trails. There are more than one abandoned rail lines that run through the city that would be prime candidates for this type of funding support.

\section{Federal Programs (TEA-21)}

The federal government also has programs through TEA-21 in which roadway expansion or redesign projects can get funding if they include support for bicycle or pedestrian consideration. 


\section{Chapter 8: Recommendations for Updates}

This is the first attempt at creating a bicycle and pedestrian plan for Lake Charles. While many factors were considered in its development, the list of things that can be reviewed is not yet exhausted. The following list gives examples of what can be done in order to update and make this plan more complete in the future.

\section{Missing Pieces}

The most glaring omission of the recommendations are the connections between Westlake to Lake Charles and Moss Bluff to Lake Charles. The reason these were omitted was because of their grand scale. The I-10 bridge will be replaced in the next decade, but the City will have very little to do with the overall design. Also the Hwy 171 bridge that connects Lake Charles to Moss Bluff is not in need of repair and would probably have to cantilever a bike bridge on the side of the existing one. The cost would be high and the scope of this report does not fall into that sort of planning.

\section{Safety Countermeasures}

Development of countermeasures for high collision locations is a focus area with high short-term returns, so it is important to consider when updating this plan. Some of the most progressive jurisdictions prepare annual reports on pedestrian-related collisions. If resources permit, this represents a best practice as it allows tracking of the efficacy of countermeasures and continual improvement of pedestrian safety. Development of countermeasures is usually accomplished through the following process:

1. Conduct collision analysis to determine the locations where pedestrian-related collisions are occurring most frequently. This is usually completed with statewide collision database information.

2. Once sites with high numbers of collisions are identified, prepare collision diagrams for the subject intersections, and, as necessary, review detail collision records.

3. Visit the site. While this step can be accomplished by a well-trained individual, it is often advantageous to involve a larger group of people. This group can include representatives from traffic engineering, maintenance, police and planning. It is also beneficial to invite policy-makers and advocates and make them aware of the City's efforts to improve pedestrian safety. For assistance in deriving pedestrian countermeasures, see the Federal Highway Administrations' PEDSAFE tool.

4. Summarize steps 1 to 3 in a report. This report demonstrates that the Parish is proactively addressing pedestrian safety and can shield the agency from liability. According to AASHTO, "If you know you have a safety problem and you fail to address it, you have more legal exposure than if you address the problem, even if you employ non-standard solutions." 


\section{Intersection Safety Improvements}

The City of Lake Charles should undertake an effort to identify and improve intersections that are without or are lacking in pedestrian safety devices. These safety devices include marked intersection crossings, lighting, and pedestrian signals. These improvements will make it more desirable and safe for pedestrians and bicycles alike to travel throughout the city without having to dash across the roadway when traffic permits.

This project could be undertaken by a student intern or possibly as a senior project for a McNeese student. It is recommended that the City of Lake Charles work with McNeese State University to address this problem, and find a reasonable and cheap solution to identifying which intersections are in the greatest need of safety improvements.

\section{Bicycle Parking Inventory}

The locations and amount of bicycle parking should be indentified in the future to assure that bicyclists have a proper place to store their bicycles once they reach their destination. As with intersection safety improvements, the bicycle parking inventory can be undertaken by a McNeese State University student as their senior or independent study project. 


\section{Appendix A: Plan and Policy Review}

\section{Related Plans}

Various planning documents have relation to this project. The studies, surveys, public input, suggestions, and recommendations made will help guide the format and information presented in the City of Lake Charles Bicycle and Pedestrian Plan.

\section{Louisiana Statewide Bicycle and Pedestrian Master Plan}

Possibly the most useful and relevant plan, the Louisiana Statewide Bicycle and Pedestrian Master Plan was completed recently and was meant to serve as a guide to other municipalities who wish to develop their own plans. The plan started by stating results from literature review and public input sessions.

A review of existing programs and policies revealed the following findings:

- There were a disproportionately high number of fatalities (107, $10.8 \%$ of all fatalities) on state highways in 2007 when compared to the pedestrian mode split (2\% of all trips).

- Historically, the number of walking and bicycling trips in Louisiana has well below the national average.

- LDOTD's current design standards and guidelines result in the construction of roadways that are often not compatible with bicycling and walking.

- There is limited and occasionally conflicting guidance on designing roadways that provide for the needs of people walking and bicycling.

- LDOTD's current sidewalk policy discourages their construction.

- Financial constraints make it difficult to fund transportation projects, causing bicycle and pedestrian accommodations to be seen as "extras," rather than an integral part of roadway design.

- Bicycling and walking facilities and accommodations are often perceived as unfunded amenities outside the scope of roadway projects.

At a series of public meetings held throughout the State in the summer and fall of 2008 , the following concerns were voiced:

\section{Challenges}

-There are few designated places to bicycle or walk safely and comfortably.

- When present, sidewalks are often narrow and provide no buffer from faster moving traffic.

- Intersections are often difficult to cross safely on foot and bike, and they often have no pedestrian accommodations such as pedestrian signals, marked crosswalks or sufficient crossing time.

- There are few designated bike lanes and bicycle facilities.

- Some roads and sidewalks are poorly maintained making walking and bicycling difficult.

- Motorists are often not aware of their responsibility to share the road with pedestrians and bicyclists.

- Land use and development patterns are often not conducive to comfortable and convenient walking and bicycling. 


\section{Opportunities}

- More people in Louisiana are walking and biking than ever before $(2.2 \%$ of the population walk to work, and $0.4 \%$ bicycle to work).

- The aging baby boomer population is looking for alternatives to driving and increased opportunities for physical activity.

- The growing awareness of environmental impacts of transportation has led to a high level of public support for increased accommodation for walking and bicycling.

- There is recognition of the cost effectiveness of making pedestrian and bicycle improvements integral parts of larger projects.

- New resources on design strategies are available, and can help increase safety for pedestrians and bicyclists.

- Staff of LDOTD is supportive of these new measures.

- Build on and support the efforts of public health agencies which promote walking and bicycling as physical activities which reduce the risk of diabetes, heart disease and other chronic diseases.

A section was of the plan offered existing policies of the Federal Government. The statewide plan shows that federal policies clearly state that the needs of bicyclists and pedestrians should be considered in every transportation project. The section goes on to mention the most recent transportation law (SAFETEA-LU) and the policies issued by the United States Department of Transportation (USDOT). The bicycle and pedestrian provisions of SAFETEA-LU include the following policies:

- "Bicycle transportation facilities and pedestrian walkways shall be considered, where appropriate, in conjunction with all new construction and reconstruction and transportation facilities, except where bicycle and pedestrian use are not permitted." (23 U.S.C. Section 217(g) (1))

- "In any case where a highway bridge deck is being replaced or rehabilitated with Federal financial participation, and bicyclists are permitted on facilities at or near each end of such bridge, and the safe accommodation of bicyclists can be provided at reasonable cost as part of such replacement or rehabilitation, then such bridge shall be so replaced or rehabilitated as to provide such safe accommodations." (23 U.S.C. Section 217(e))

The Louisiana Statewide plan also mentions the USDOT policy on bicycling and walking. The document states that "bicycling and walking facilities will be incorporated into all transportation projects unless exceptional circumstances exist." It also states that in all urbanized areas bicycle and pedestrian ways "shall be established" with exception for situations where bicycles and pedestrians are prohibited, where the cost of accommodation exceeds $20 \%$ of the total project cost or where there is an absence of need. The policy also states that any exceptions to the policy should be approved at a senior level.

The fact that the federal government's policies on transportation are highlighted in this plan shows that the State of Louisiana wants to catch-up to the rest of the nation with its planning for bicycles and pedestrians. The report goes on to mention statistics that show Louisiana has lower rates of walking and biking that the national average and also has higher rates of accidents involving bikes and pedestrians than the rest of the nation. These two statistics come together to show that attention paid to planning and infrastructure support for pedestrians and bicyclists is not up to national standards. 
The statewide plan further goes on to give guidelines for project development that is meant to ensure that pedestrian and bicycle improvements are cost effective and necessary. The policies and objectives thatare included after this list show how serious the department is in planning for and implementing improvements. It gives examples of design policies and also gives a list of documents that can be used as a reference for types of designs.

\section{City of Lake Charles Master Plan}

Created in response to the threats posed by Hurricanes Rita and Katrina, this plan had the purpose to set out a vision of how Lake Charles intends to grow as a community. It states a vision and gives three development goals. It also gives recommendations on how that development should occur and what steps can be taken in order to develop along within the vision set forth by the City.

Section 6.2.2.5 discusses metropolitan transportation and also talks about alternative modes of transportation stating:

"As the cost of gasoline continues to rise, demand for alternative modes of transportation will as well. In as much as the city can lay the groundwork for a non-automobile transportation system, it will see its usage increase..."

The plan states that transportation is the second largest expenditure of a household and suggests human powered transport could be viable if Lake Charles provides options. The plan goes further to say, "cyclists and pedestrians desire similar environments: calm traffic conditions, appealing streetscapes, and a convenient mix of uses." It promotes increasing public awareness and publication of the Nonmotorized Study for the Lake Charles Metropolitan Area, which showcases potential improvements to the system.

If the city to provides these conditions, it will see increasing demand for use of its trails and bike lanes. Suggestions are offered to increase cycling and pedestrian activity within a community.

- Establishment of separate cycling facilities along heavily traveled roads and at intersections.

- Traffic-calming in most residential neighborhoods. Many cities have introduced alterations such as road narrowing, raised intersections and crosswalks, traffic circles, extra curves and zigzag routes, speed humps, and artificial dead ends created by mid-block street closures. Traffic calming is usually area-wide and not for isolated streets.

- Ample bike parking. Local governments and public transit systems provide many bike parking facilities. Private developers and building owners are required by local ordinances to provide specified minimum levels of bike parking both within and adjacent to their buildings.

- Full integration of cycling with public transportation; particularly by equipping Lake Charles buses with racks to carry bicycles.

\section{Lake Charles Metropolitan Transportation Plan}

The 2034 Lake Charles Metropolitan Transportation Plan (MTP) is the primary reason behind the development of this report. This plan was released in 2009 and gives a 25 year vision of what 
transportation in the Lake Charles Metro Region will like. In order to receive state and federal funding on projects, they must be included in the MTP.

On pg. 3-26, in the pedestrian and bicycle section of the plan, the authors directly state:

"There are currently no local jurisdictional bike or pedestrian plans. Calcasieu Parish and the City of Lake Charles have provided wide shoulders in various locations for bike use, but few routes are designated and no inventory exists. Many neighborhoods have sidewalks, but a sidewalk inventory of the region is not available. A systematic inventory of ADA sidewalk compliance is also not available for the study area."

The plan goes further to state in its Pedestrian Facilities Analysis sections on page 3-30:

"There was no current inventory of existing facilities to use as a baseline, but information gathered through the public visioning and consultation processes provided sufficient information to develop the following list of deficiencies.

- Lack of inventory of existing non- motorized facilities to use as a baseline for developing and continuous analysis.

- No plan for the development of a connected transportation network that meets the needs of people who want or need to use non-motorized modes.

- Lack of sidewalks in some of Lake Charles commercial areas.

- Insufficient network of sidewalks and bikeways to schools."

These quotes are a glaring revelation of the lack of planning for pedestrians and bicycles in the area. A survey, suggestions, and quotes obtained from citizens at a public meeting shed light on the desire for the region to focus on pedestrian infrastructure and program improvements. This plan states the need for increased planning for pedestrian and bicycle facilities while offering evidence of public support. The Lake Charles 2034 MTP will be an integral part of the Calcasieu Parish Pedestrian and Bicycle Master Plan.

\section{Lake Charles Metropolitan Area Non-Motorized Transportation Study}

Although the first of its kind in size and scope, this is not the first attempt to conduct an inventory and analysis of bicycle and pedestrian support in Calcasieu Parish or Lake Charles. In 1996, Aaron Iverson published the "Lake Charles Metropolitan Area Non-Motorized Transportation Study." This paper was completed as a thesis for the University of Illinois at Urbana-Champaign and was presented to IMCAL. It was compiled in response to the 1995 Lake Charles Metropolitan Transit Plan. It focused on two main things: the existing conditions of bicycle facilities and pedestrian support and recommendations on how to improve deficiencies.

The term "bicycle facilities" refers to bicycle routes, trails or lanes, and parking. There was only bike trail, which was a $4 \mathrm{ft}$ wide "multi-use" trail along Lakeshore Drive. For pedestrian support, this study utilized parameters to measure pedestrian friendliness of the Lake Charles Metro Area using indicators such as: ease of street crossing, sidewalk continuity, street patterns, and topography and environment. The report concluded that there were minimal facilities for bicycling parking, with no plan for bike routes or trails and that pedestrian support was scattered and poorly maintained. The study 
subsequently found that the weather in Southwest Louisiana was optimal for pedestrian and bike travel, but the lack of infrastructure did not allow for these activities.

While not giving a complete inventory of sidewalks within the region, this study does provide a good survey of intersections that provide pedestrian signals. This will assist me in deciding which intersections should be targeted for improvements. The study further goes on to suggest 29 bike routes. The suggested routes are put in the format of the Federal Highway Administration's evaluation method. This method shows necessary information such as traffic volume and speed, the reason selected, and cost. While this information is necessary to include for the suggestions, other supplemental information such as photographs, cross-sections, road redesign schematics, and a prioritization schedule was not included. While not a complete plan, The Lake Charles Metropolitan Area Non-Motorized Transportation Study of 1996 will be used as a valuable reference and guide for the completion of the Calcasieu Parish Bicycle and Pedestrian Plan.

\section{Current Louisiana Bicycling Laws}

The inclusion of these laws are meant to serve as a reference to the public and decision-makers. Possibly the most important of all laws is RS32:194, which grants the same rights of person riding a bicycle on a state highway to a person driving an automobile.

\section{RS 32:106 Methods of Giving Hand and Arm Signals}

All signals herein required to be given from the left side of the vehicle in the following manner and such signals shall indicate as follows:

- Left Turn: Hand and arm extended horizontally with the had open and the back of the hand to the rear

- Right Turn: Hand and arm extended upward at the angle of forty-five degrees from shoulder or elbow, with the hand open and back of the hand to the rear

- Stop or Decrease Speed: Start hand and arm extended downward at an angle of forty-five degrees from shoulder or elbow, with the hand open and the back of the hand to the rear

\section{RS 32:193 Operation of Bicycles; General Provision}

The regulations applicable to bicyclists shall apply whenever a bicycle is operated upon a highway or upon any path set aside for the exclusive use of bicycles.

\section{RS 32:194 Traffic Laws Apply to Persons Riding Bicycles}

Every person riding a bicycle upon a highway of this state shall be granted all the rights and shall be subject to all the duties applicable to the driver of a vehicle.

\section{RS 32:195 Riding on Bicycles}

- A person propelling a bicycle shall not ride other than upon or astride a permanent or regular seat attached thereto.

- No bicycle shall be used to carry more persons at one time than the number for which it is designed and equipped. 
- A person operating a bicycle shall at all times keep at least one hand upon the handle bars thereof.

\section{RS 32:196 Clinging to Vehicles}

No person riding upon any bicycle shall attach himself or the bicycle to any vehicle upon a highway.

\section{RS 32:197 Riding on Roadways and Bicycle Paths}

- Every person operating a bicycle upon a roadway shall ride as near to the right side of the roadway as practicable, exercising due care when passing a standing vehicle or one proceeding in the same direction.

- Persons riding bicycles upon a roadway shall not ride more than two abreast except on paths or parts of roadways set aside for the exclusive use of bicycles.

- Whenever a usable path for bicycles has been provided adjacent to a roadway, bicycle riders shall use such path and shall not use the roadway.

\section{RS 32:199 Bicycle Helmets; Restraining Seats}

With regard to any bicycle used on a public roadway, public bicycle path, or other public right-of-way, no parent, guardian, or person with legal responsibility for the safety and welfare of a child shall knowingly allow any of the following:

- Such child under the age of twelve to operate or ride as a passenger on a bicycle without wearing an approved helmet of good fit fastened securely upon the head with the straps of the helmet.

- Such child who weighs less than forty pounds or is less than forty inches in height to be a passenger on a bicycle without being properly seated in and adequately secured to a restraining seat.

Notice shall be provided in accordance with the following provisions:

- A person regularly engaged in the business of selling or renting bicycles shall post a sign stating the following: "Louisiana law requires a bicycle operator or passenger under the age of twelve years to wear a bicycle helmet when riding a bicycle. Louisiana law also requires a passenger who weighs less than forty pounds or is less than forty inches in height to be properly seated in and adequately secured to a restraining seat."

\section{RS 32:329 Bicycles; Front Lamps; Side and Rear Reflectors}

Every bicycle when in use at nighttime shall be equipped with a lamp on the front which shall emit a white light visible from a distance of at least five (5) hundred feet tot eh front and with a red reflector on the rear and a reflector on each side facing outward at the right angle to the bicycle frame, all of a type approved by the department which shall be visible from all distances within six (6) hundred feet to one hundred feet to the rear when directly in front of lawful lower beams of headlamps on a motor vehicle. A lamp emitting a red light visible from a distance of five (5) hundred feet to the rear may be used in addition to the red reflector.

\section{RS 32:346 Brakes on Bicycles}

Every bicycle shall be equipped with a brake which will enable the operator to make the braked wheels skid on dry, level, clean pavement. 


\section{Appendix B: Design Guidelines}

These guidelines are based on The Road Design Manual for the LDOTD and have suggestions borrowed from two AASHTO books, A Policy on Geometric Design of Highways and Streets and Bike Book 1999 and The City of San Luis Obispo's Bicycle Master Plan. Certain policies should be considered when planning any new roadway improvement.

A Policy on Geometric Design of Highways and Streets, AASHTO At certain locations or in certain corridors, it is appropriate to further supplement the existing highway system by providing specifically designated bikeways (for either exclusive or nonexclusive bicycle use). (Page 101)

Provisions for bicycle facilities should be in accordance with the AASHTO Guide for the Development of Bicycle Facilities. (Page 367)

Even if specific bicycle facilities are not provided, consideration should be given to other practical measures for enhancing bicycle travel on the highway. (Page 367)

The Road Design Manual and the AASHTO Bike Book also both state that increasing accommodations for pedestrians and bicyclists may require a reduction in space for motor vehicles, often in the form of narrower travel lanes and smaller intersections. The Parish therefore must consider bicycles and pedestrians whether or not specially designated facilities are provided. Narrower travel lanes can provide increased space for paved shoulders or bicycle lanes and reduce the distance that pedestrians must travel to cross the road. In regards to legal responsibility, the Parish may be liable when it can be shown that it should have been aware of deficiencies that have been shown to contribute to crashes, such as wide expansion joints, sudden pavement drop-offs, unsafe drain grates, etc.

\section{Pedestrian Facilities}

Within the past few decades pedestrian travel planning in the area has received, at best, only secondary attention, with much of the emphasis being placed on the access and mobility of automobiles. Many American cities are combating this deficit by undertaking significant efforts to revise their existing plans, policies, and design standards in order to create more walkable communities and a more multi-modal and balanced transportation network.

Each day, nearly everyone in Lake Charles is a pedestrian, for at least some part of every trip. Pedestrian infrastructure availability and safety issues are garnering the attention of many Parish residents who are demanding more consideration when it comes to transportation planning. There are many opportunities to improve pedestrian conditions and in doing so, make Lake Charles communities more attractive and livable.

This chapter was developed utilizing a various array of references, but the bulk of the suggestions come from two sources, The American with Disabilities Act Access Guidelines (ADAAG) and the FHWA produced book Designing Sidewalks and Trails for Access. The main references are showcased below. 


\section{ADAAG Regulations:}

Clearances (Sections 403.5) - Clear Width of walking shall be a minimum of 3 feet (36 inches), except as provided at turns or passing spaces.

Passing Spaces - An accessible route with a clear width less than 5 feet (60 inches) shall provide passing spaces at intervals of 200 feet minimum. Passing spaces shall be either: (a) a space 5 feet (60 inches) minimum by 5 feet (60 inches) minimum; or, (b) an intersection of two walking surfaces providing a t-shaped space where the base and arms of the t-shaped space extend 4 feet (48 inches) minimum beyond the intersection.

\section{FHWA Design Sidewalks and Trails for Access}

Width - The pedestrian "zone" (sidewalk) should be at least 5 feet (60 inches) wide for two pedestrians to travel side by side without passing other pedestrians, or for two people going in opposite directions to pass one another. The pedestrian zone should never be less than 3 feet (36 inches). This minimum width is only acceptable when: (1) A wider width is impossible; (2) The narrow width continues for as short a distance as possible; and (3) Passing spaces are provided at intervals of no more than 200 feet.

\section{Sidewalk Width}

The width of a sidewalk depends primarily on the number of pedestrians who are expected to use the sidewalk at a given time - high-use sidewalks should be wider than low-use sidewalks.

Table 9: Sidewalk Width Guidelines

\begin{tabular}{|l|l|}
\hline \multicolumn{1}{|c|}{ Type of Roadway } & \multicolumn{1}{|c|}{ Suggested Width } \\
\hline Local or collector streets & (5 ft) \\
\hline Arterial or major streets & (6 to $8 \mathrm{ft})$ \\
\hline CBD areas & (8 to $12 \mathrm{ft})$ \\
\hline Along parks, schools, and other major pedestrian generators & (8 to $10 \mathrm{ft})$ \\
\hline
\end{tabular}

Source: AASHTO

\section{Sidewalk Buffer Width}

Buffers between pedestrians and motor vehicle traffic are important to provide greater levels of comfort, security, and safety to pedestrians. Landscaped buffers provide a space for poles, signs, and other obstructions; they serve as a snow storage area; and they protect pedestrians from splash. The

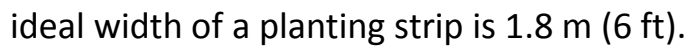

Table 10: Sidewalk Buffer Guidelines

\begin{tabular}{|l|l|}
\hline \multicolumn{1}{|c|}{ Type of Roadway } & \multicolumn{1}{c|}{ Suggested Width } \\
\hline Local or collector streets & (2 to $4 \mathrm{ft})$ \\
\hline Arterial or major streets & (4 to $6 \mathrm{ft})$ \\
\hline
\end{tabular}

Source: AASHTO 


\section{Bicycle Facilities}

Bicycle facilities can cover a wide range of possibilities. Facility types range from a shared lane with motorized traffic with no accommodation for to a separate designated bicycle path. In selecting which type of facility to use, it is important to consider what type of cyclist and the roadway characteristics. According to the Federal Highway Administration manual "Selecting Roadway Design Treatments to Accommodate Bicycles," there are three primary factors which influence bicycle travel on streets. The three factors are lane widths, traffic speeds, and traffic volumes.

Lane Width - Lane widths are critical for allowing enough room for the combined movement of bicycles and automobiles. There are a few highways and roadways within Calcasieu Parish that already have shoulders of at least 4 feet and could be used as bicycle lanes if stripping and signage were provided. National standards require a minimum right-hand curb lane width of 14 feet to safely accommodate shared use. There are many roads in Calcasieu Parish that have lane widths of at least 14 feet, but roadway speed will have to be considered on these roads.

Traffic Speeds - In order to be considered safe for shared roadway use, traffic speeds of 35 $\mathrm{mph}$ are required. Bicycle lanes can be substituted for shared roadway use if speed conditions exist that are greater than $35 \mathrm{mph}$. Although the minimum bicycle lane width is $4 \mathrm{feet}$, a sliding scale should be developed that takes into account the added buffer needed with increased automobile speed. While some collector roads located within existing communities have low speed limits, most of the roads connecting communities within Calcasieu Parish have speed limits above $35 \mathrm{mph}$ and should not be considered suitable for shared use.

Traffic Volumes - An annual average daily traffic volume of less than 10,000 vehicles is recommended by the FHWA for shared roadway use. Most of the principal arterials in Calcasieu Parish have an annual daily traffic volume of more than 10,000 vehicles and are not recommended for shared use. Collector and local roads are more conducive to shared use because of their lower traffic volumes and lower traveling speeds and should be considered preferable for a designation of a bicycle route network. Because population centers within Calcasieu Parish are separated by well traveled and roads with high rate of speeds, these connections should be made with exclusive bike lanes where practical.

Table 11: Bicycle Facility Design Standards

\begin{tabular}{|c|c|c|c|}
\hline \multicolumn{5}{|c|}{ Bicycle Facilities Design Standards } \\
\hline Type of Bicycle Facility & Average Daily Traffic & Posted Speed Limit & Travel Lane \\
\hline Shared Lanes & $<3,000$ & $\leq 30 \mathrm{mph}$ & $12 \mathrm{ft}$ \\
\hline Wide Curb Lanes & $<10,000$ & $\leq 30 \mathrm{mph}$ & $14 \mathrm{ft}$ \\
\hline Bicycle Lanes & $\geq 10,000$ & $\geq 35 \mathrm{mph}$ & $4-6$ Striped Lane \\
\hline
\end{tabular}




\section{Redesigning Roadways to Accommodate Bicycles (Road Diets)}

"ROAD DIETS" are often conversions of four lanes into three lanes (two through lanes and a center turn lane). The fourth lane may be converted to bicycle lanes, sidewalks, and/or on-street parking. In other words, existing space is reallocated; the overall area remains the same.

Under most average daily traffic (ADT) conditions tested, road diets have minimal effects on vehicle capacity, because left-turning vehicles are moved into a common two-way left-turn lane. However, for road diets with ADTs above approximately 20,000 vehicles, there is a greater likelihood that traffic congestion will increase to the point of diverting traffic to alternate routes.

Road diets can offer potential benefits to both vehicles and pedestrians. On a four-lane street, drivers change lanes to pass slower vehicles (such as vehicles stopped in the left lane waiting to make a left turn). In contrast, drivers' speeds on two-lane streets are limited by the speed of the lead vehicle. Thus, road diets may reduce vehicle speeds and vehicle interactions during lane changes, which potentially could reduce the number and severity of vehicle-to-vehicle crashes. Pedestrians may benefit because they have fewer lanes of traffic to cross, and because motor vehicles are likely to be moving more slowly. The Federal Highway Administration (FHWA) report Safety Effects of Marked vs. Unmarked Crosswalks at Uncontrolled Locations found that pedestrian crash risk was reduced when pedestrians crossed two- and three-lane roads, compared to roads with four or more lanes.

The road diet formula can be used on many roads throughout the City of Lake Charles, such as Broad St or $5^{\text {th }}$ Ave. It is recommended that all four lane roads be considered for conversion to three lanes, plus inclusion of bicycle lanes.

Figure 32: Road Diet Example

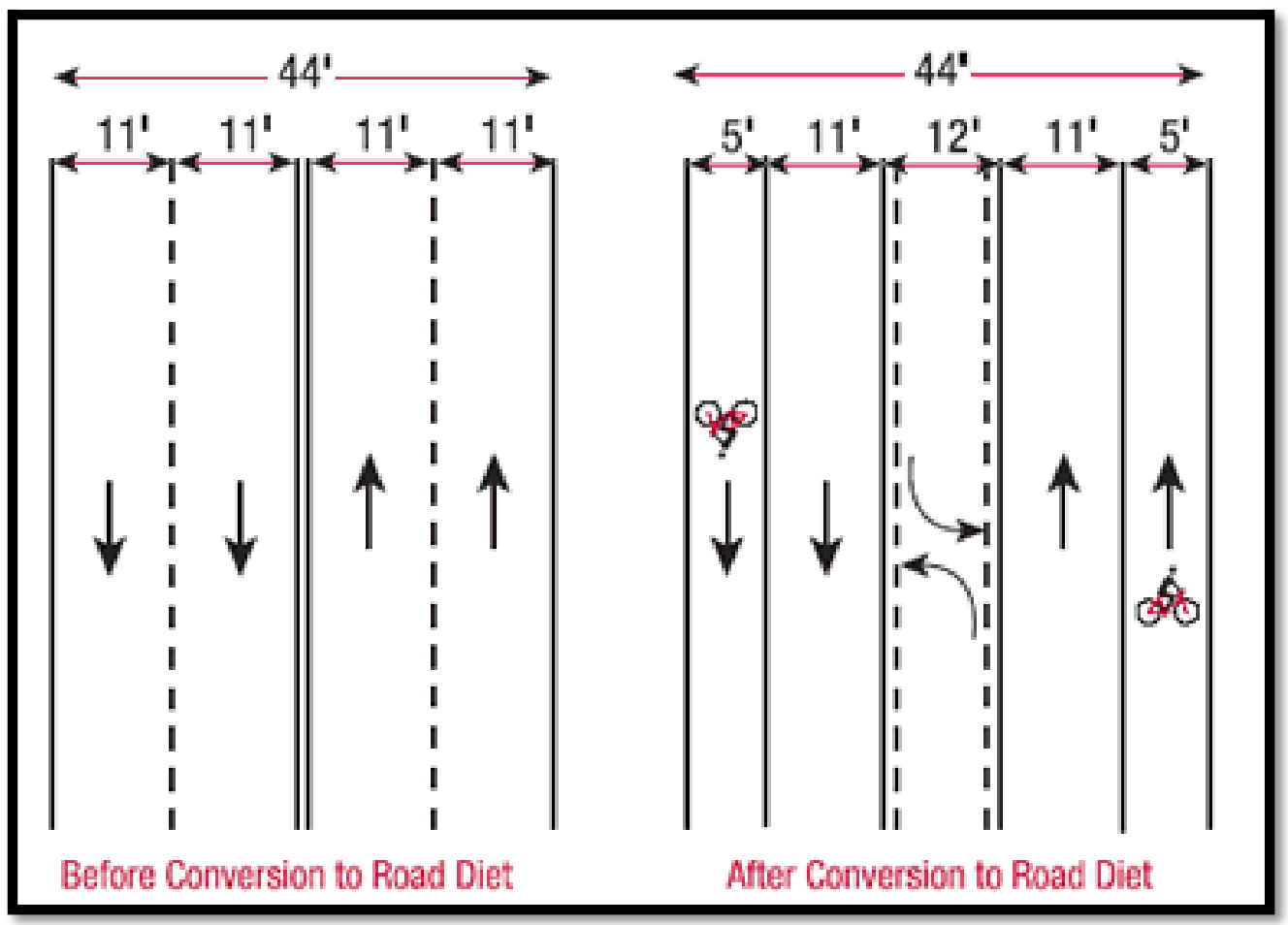

Bicycle and Pedestrian Master Plan 


\section{Shared Lanes}

On streets with average daily traffic (ADT) of less than 3,000 vehicles per day or average travel speeds of less than $30 \mathrm{mph}$, a standard 12-foot travel lane is sufficient to accommodate both motorist and cyclist. Unless the roadway is part of a designated bicycle route or is heavily used by cyclists, perhaps as an access route to a school or playground, no special signage is necessary. If the road is used regularly by bicyclists, then a marked "sharrow" is recommended for the roadway.

\section{Bicycle Routes}

A bicycle route is a system of bikeways designated by the jurisdiction having authority with appropriate directional and informational route markers. Bicycle routes share roadways with automobiles. Signing of shared roadways indicates to cyclists that there are particular advantages to using these routes compared to alternate routes. Bike routes should establish a continuous routing, but may be a combination of any and all types of bikeways. There are several reasons for designating signed bike routes:

a. The route provides continuity to other bicycle facilities such as bike lanes and shared use paths.

b. The road is a common route for bicyclists through a high demand corridor.

c. In rural areas, the route is preferred for bicycling due to low motor vehicle traffic volume or paved shoulder availability.

d. The route extends along local neighborhood streets and collectors that lead to an internal neighborhood destination such as a park, school or commercial district.

\section{Wide Curb Lanes}

In urban areas, wide curb lanes are recommended for use on roadways with posted speed limits of 30 $\mathrm{mph}$ or less and where ADT volumes are less than 10,000. In general, $4.2 \mathrm{~m}$ (14 feet) of usable lane width is the recommended width for shared use in a wide curb lane. Usable width normally would be from edge stripe to lane stripe or from the longitudinal joint of the gutter pan to lane stripe. Wide curb lanes can also be used in rural areas; however, under high-volume or high-speed conditions a paved shoulder is preferred. No special signage is required.

\section{Bicycle Lanes}

Bike lanes are incorporated when it is desirable to delineate available road space for preferential use by bicyclists and motorists, and to provide for more predictable movements by each. Bike lane markings can increase a bicyclist's confidence in motorists not straying into their path of travel. Bicycle lanes are best suited for use in urban areas on arterial roadways with ADT volumes greater than 10,000 vehicles per day and average travel speeds of over $30 \mathrm{mph}$. 
Bike lanes should be one-way facilities and carry bike traffic in the same direction as adjacent motor vehicle traffic. Two-way bike lanes on one side of the roadway are not recommended when they result in bicycles riding against the flow of motor vehicle traffic. In rural areas, designated bike lanes may be preferred over an undesignated paved shoulder where heavy bicycle traffic is expected, for example near a bicycle trip generator such as a park or school or on a designated bicycle route. Pavement markings and signage are used to designate the lane for bicycle use.

Table 12: Bike Lane Design Guidelines

\begin{tabular}{|c|c|c|c|}
\hline \multicolumn{4}{|c|}{ Bike Lane Design Standards } \\
\hline Min. Width (ft.) & Average Daily Traffic & Posted Speed Limit & Striping \\
\hline 4 & $\geq 10,000$ & $\leq 35$ & 6 inches \\
\hline 5 & $\geq 10,000$ & $\geq 40$ & 6 inches \\
\hline 6 & $\geq 15,000$ & $\geq 45$ & 6 inches \\
\hline
\end{tabular}

\section{Design Considerations}

Bicycles have special design considerations that must be paid attention to. The following two suggestions are based on the AASHTO Bike Book.

\section{Pavement Surface Quality}

The smoothness of the riding surface affects the comfort, safety and speed of bicyclists. Pavement surface irregularities can do more than cause an unpleasant ride. Pavement surfaces should be smooth, and the pavement should be uniform in width. Wide cracks, joints or drop-offs at the edge of traveled way parallel to the direction of travel can trap a bicycle wheel and cause loss of control; holes and bumps can cause bicyclists to swerve into the path of motor vehicle traffic. In addition, a reduction in the operating speed of the bicyclist below a comfortable level results in less stability of the bicycle. As pavements age it may be necessary to fill joints or cracks, adjust utility covers or even overlay the pavement in some cases to make it suitable for bicycling.

\section{Drainage Inlet Grates}

Drainage inlet grates and utility covers are potential obstructions to bicyclists. Therefore, bicycle-safe grates should be used, and grates and covers should be located in a manner which will minimize severe and/or frequent maneuvering by the bicyclist. When new highway facilities are constructed, curb opening inlets should be considered to minimize the number of potential obstructions. Drainage inlet grates and utility covers should be placed or adjusted to be flush with the adjacent pavement surface. Drainage inlet grates with slots parallel to the roadway, or a gap between the frame and the grate, can trap the front wheel of a bicycle, causing loss of steering control. If the slot spacing is wide enough, narrow bicycle wheels can drop into the grates. Conflicts with grates may result in serious damage to the bicycle wheel and frame and/or injury to the bicyclist. These grates should be replaced with bicyclesafe, hydraulically efficient versions. When this is not immediately possible, a temporary correction is to weld steel cross straps or bars perpendicular to the parallel bars at 100-mm (4-inch) center-to-center. 


\section{Grade Separated and Shared Use Paths}

\section{Multi-Use Paths}

Multi-use and bicycle paths, are separate special use facilities providing both physical and visual separation from motorized traffic. They should be considered as a supplement to the roadway network providing access to otherwise inaccessible areas and, in general, should not be constructed parallel to existing roadways. Bicycle paths can also be used as spur connectors from the street network to provide non-motorized access points to facilities such as schools, parks and playgrounds.

Standards for the development of multi-use paths are as follows:

- Width of between 8-12 feet (depending on expected traffic flow)

- Grades should do not exceed 8.3 percent

- Cross slopes on paved surfaces that do not exceed 2 percent and cross slopes on non-paved surfaces that do not exceed 5 percent

- A firm and stable surface

The follwoing picture, courtesy of the federal highway administration, showcases recommended widths in a visual setting.

Figure 34: Rendering of Example Paved Path

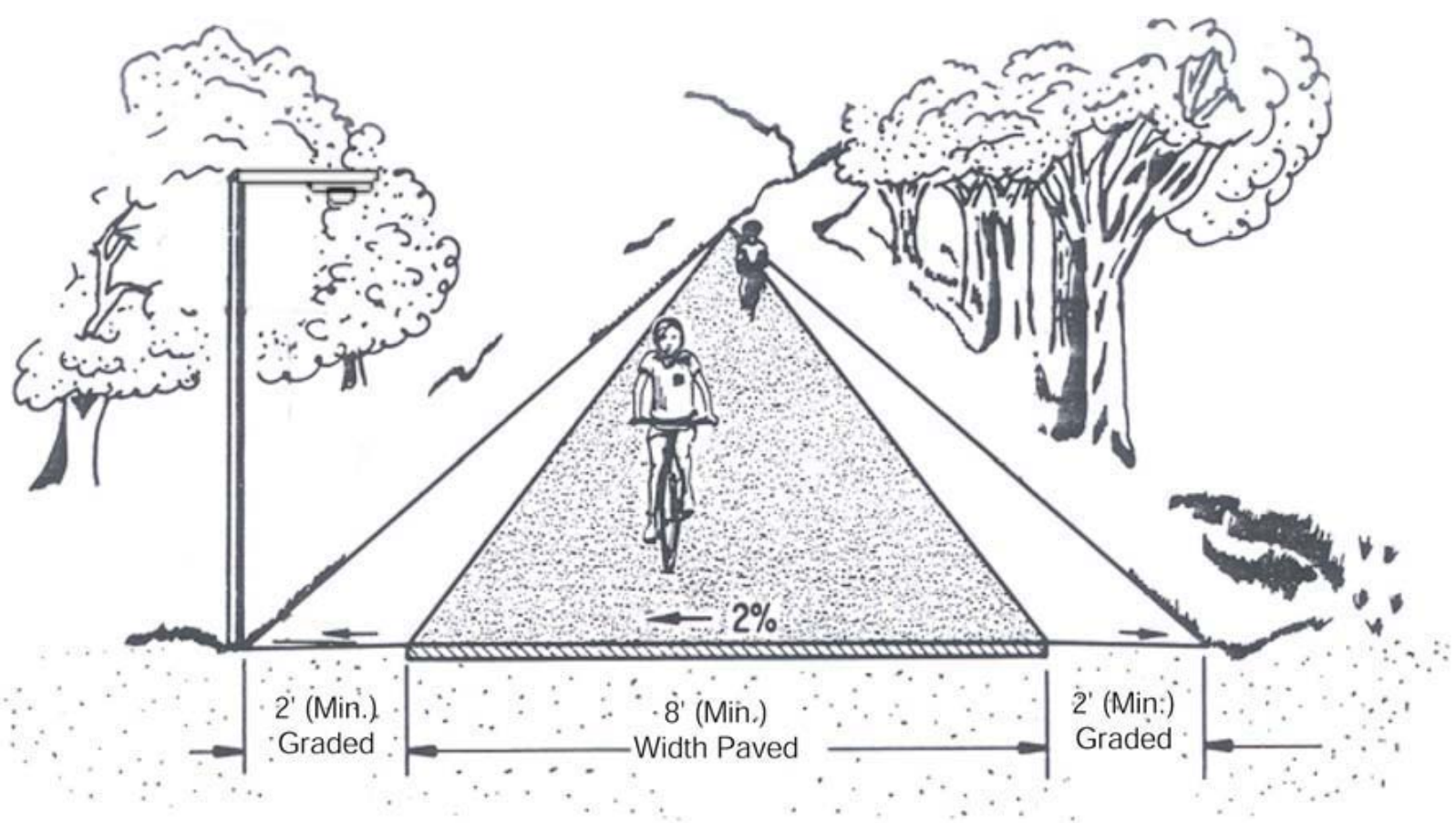




\section{Mountain Bike and Walking Trails}

Mountain bike and walking trails are for those who wish to recreate on a more naturalistic setting. These trails are generally unpaved, but may have a surface like crushed rock or cinder. These trails are separated from automobile traffic and can offer opportunities that range from a "short-cut" through neighborhoods or a chance to walk your dog. These trails offer less accommodation for all users than multi-use paths. East Baton Rouge Parish currently offers two mountain bike trails built by the Baton Rouge Area Mountain Bike Association (BRAMBA).

\section{Conflict Concerns}

Multi-use paths attract a variety of user groups wheeled and non-wheeled, who often have conflicting needs. All of these modes are affected by sudden changes in the environment and by other trail users, such as bicyclists, who travel at high speeds. To improve the shared-use path experience for all users, including people with disabilities, designers and planners should be aware of potential conflicts and employ innovative solutions whenever possible. Basic conflicts can be reduced by:

- Providing information, including signage, in multiple formats that clearly indicates permitted users and rules of conduct;

- Ensuring that the shared-use path provides sufficient width and an appropriate surface for everyone, or providing alternate paths for different types of users;

- Providing sufficient separation for users traveling at different speeds. For example, if volume and space permits, bicyclists and pedestrians should have different lanes or pathways;

- Providing the necessary amenities for all users. For example, bicyclists require bike racks or lockers;

- Considering the needs of people with disabilities within all of the user groups permitted on the path. For example, many individuals with disabilities may use a longer hand cycle or wider tricycle design that may not be compatible with bike racks, bathroom stalls, or lockers of limited width. Longer and wider equipment may need additional maneuvering space in restrooms and when transferring from the chair to benches.

Figure 36: Example Precautionary Trail Sign

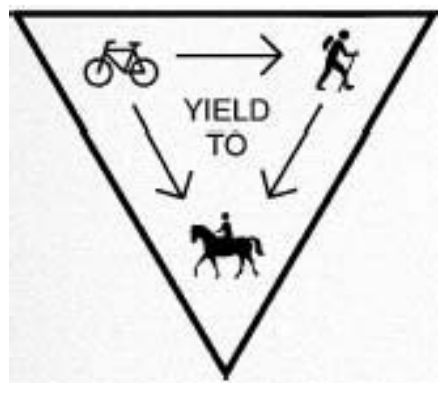




\section{Appendix C: Maintenance Guidelines}

Preventive Maintenance Policy: Preventive maintenance, such as filling in cracks, is critical to keeping both on-street and off-street bike routes safe and comfortable to ride on while prolonging the life of infrastructure.

Figure 37: Debris on Paved Shoulder Bikeway

\section{Sweeping}

Trails and on-street bikeways need to be swept on a regular basis. Many facilities regularly fill up with sand, trash, glass, and other debris that needs to be removed to keep the bikeway safe. Many bicyclists avoid routes with debris to reduce the chance of getting a flat tire.

Paths Sweeping Policy: Each Bikeway and Multi-use path shall be completely swept three times per year.

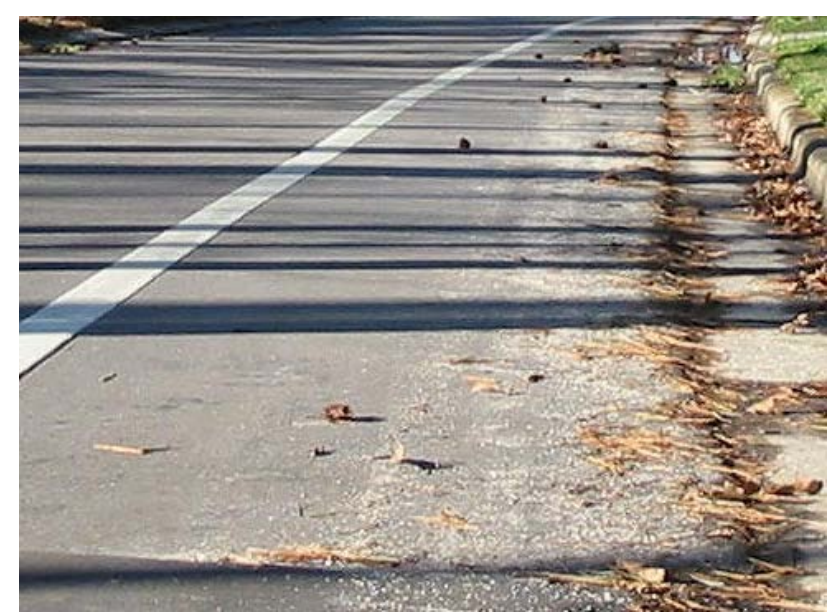

\section{Trash and Debris Pick-Up}

Trails should have trash receptacles placed at access points. The use of volunteers and community service crews to clean up trail corridors is strongly encouraged.

Trail Trash and Debris Pick-Up Policy: Once per week, litter and debris will be cleared from the corridor and trash bins will be emptied on off-street trails.

On-Street Bikeways Accident Debris Cleanup Policy: If a tow truck that is under a City contract assists in removing damaged vehicles, the towing company is responsible for removing all accident debris, including broken glass. If no tow truck is involved, then PW street maintenance crews will remove the debris upon notification. 


\section{Appendix D: FHWA Crosswalk Guidelines}

The following list is a summary of the guidelines for designing crosswalks by the Federal Highway Administration.

Before installing new marked crosswalks, an engineering study is needed to show whether the location is suitable for a marked crosswalk.

It is recommended that a minimum of 20 pedestrian crossings per peak hour (or 15 or more elderly and/or child pedestrians) exist at a location before placing a high priority on the installation of a marked crosswalk alone.

Where speed limit exceeds $40 \mathrm{mph}$, marked crosswalks alone should not be used at unsignalized locations.

$>$ Possible increase in pedestrian crash risk may occur if crosswalks are added without other pedestrian facility enhancements. Whether marked crosswalks are installed, it is important to consider other pedestrian facility enhancements, as needed, to improve the safety of the crossing (e.g., raised median, traffic signal, roadway narrowing, enhanced overhead lighting, traffic calming measures, curb extensions).

Crosswalks should not be installed at locations which could present an increased safety risk to pedestrians, such as where there is poor sight distance, complex or confusing designs, substantial volumes of heavy trucks, or other dangers, without first providing adequate design features and/or traffic control devices.

> The raised median or crossing island must be at least $4 \mathrm{ft}$ wide and $6 \mathrm{ft}$ long to adequately serve as a refuge area for pedestrians in accordance with MUTCD and AASHTO guidelines. 


\section{Appendix E: Cost Estimate Guidelines}

In order to estimate the cost of various improvements, a generic estimator worksheet was created. Each estimate is cited by either a municipality or state transportation department. These costs take into account the basic cost of engineering and construction, but do not consider costs of right-of-way acquisition or administrative costs.

Table 13: Cost Estimate Assumptions

\begin{tabular}{|c|c|c|c|c|}
\hline Type of Improvement & Per Mile & $\begin{array}{c}\text { Per Sq. } \\
\text { Ft. }\end{array}$ & $\begin{array}{c}\text { Per Linear } \\
\text { Ft. }\end{array}$ & Source \\
\hline Culvert and Cover Ditch (Per Side) & $\$ 800,000$ & $\mathrm{n} / \mathrm{a}$ & $\$ 151.52$ & Calcasieu Parish Engineering \\
\hline $5 \mathrm{ft}$ Paved Shoulder (Both Sides) & $\$ 160,000$ & $\$ 3.03$ & $\$ 30.30$ & Florida DOT (2009) \\
\hline 5 ft Sidewalk (One Side) & $\$ 132,000$ & $\$ 5.00$ & $\$ 25.00$ & City of Lake Charles (2010) \\
\hline Curb \& Gutter (One Side) & $\$ 79,000$ & $\mathrm{n} / \mathrm{a}$ & $\$ 15.00$ & City of Albemarle (2008) \\
\hline Signage & $\$ 2,000$ & $\mathrm{n} / \mathrm{a}$ & $\$ 0.38$ & City of Albemarle (2008) \\
\hline Stripping & $\$ 15,000$ & $\mathrm{n} / \mathrm{a}$ & $\$ 2.84$ & City of Albemarle (2008) \\
\hline $12 \mathrm{ft}$ Multi-Use Path & $\$ 175,000$ & $\$ 2.76$ & $\$ 33.14$ & Florida DOT (2009) \\
\hline $10 \mathrm{ft}$ Crushed Rock walkway & $\$ 80,000$ & $\$ 1.52$ & $\$ 15.15$ & City of Albemarle (2008) \\
\hline Bike Lane & $\$ 50,000$ & $\mathrm{n} / \mathrm{a}$ & $\$ 9.47$ & USDOT (2010) \\
\hline Narrowing Lanes & $\$ 2,000$ & $\mathrm{n} / \mathrm{a}$ & $\$ 0.38$ & USDOT (2010) \\
\hline
\end{tabular}




\section{Appendix F: Bibliography}

1. 2034 Lake Charles Metropolitan Transportation Plan. 2009.

2. Ada County Highway District. Pedestrian-Bicycle Transition Plan 2005.

3. Iverson, Aaron A. (1996). Lake Charles Metropolitan Area Non-Motorized Transportation Study. University of Illinois at Urbana-Champaign

4. American Association of State Highway and Transportation Official Task Force on Geometric Design. Guide for the Development of Bicycle Facilities. (AASHTO) 1999.

5. Institute of Transportation Engineers. Transportation Planning Handbook. Englewood Cliffs, New Jersey: Prentice-Hall, Inc., 1992.

6. United States Department of Transportation. Federal Highway Administration. Selecting Roadway Design Treatments to Accommodate Bicycles. Great Falls, Virginia. Center for Applied Research1992.

7. Pucher, John et al. (2009). Infrastructure, Programs, and Policies to Increase Bicycling: An International Review. Preventative Medicine.

8. Safe Routes to School: Putting Traffic Safety First. (2009). How Safe Routes to School Initiatives Protect Children Walking and Bicycling.

9. Hudson, George. What's Under Foot? Multi-use Trail Surfacing Options.

10. Racca, David and Dhanju, Amardeep. (2006). Property Value/Desirability Effects of Bike Paths Adjacent to Residential Areas.

11. Bhattarai, Prasanta. (2007). A GIS Based Walkability Analysis.

12. Fehr \& Peers. (July 2007). Pedestrian Plans - State of the Practice

13. Local Road Safety Improvement Projects: Program Guidelines \& Policies 2009/2010. Louisiana Technical Assistance Program.

14. Traffic Controls for Bicycle Facilities. (May 2004). Manual for Uniform Traffic Control Devices.

15. Louisiana Statewide Bicycle and Pedestrian Master Plan. (September 2009). The Louisiana Department of Transportation and Development.

16. U.S. Department of Transportation Federal Highway Administration. Recommended Guidelines/Priorities for Sidewalks and Walkways. PEDSAFE. http://www.walkinginfo.org/pedsafe/moreinfo sidewalks.cfm

17. Safe Routes to School. Sidewalks Engineering Guide. http://www.saferoutesinfo.org/guide/engineering/sidewalks.cfm

18. Bike Lanes. Pedestrian and Bicycle Information Center. Bicycleinfo.org http://www.bicyclinginfo.org/engineering/facilities-bikelanes.cfm

19. rssWeather.com. Climate for Lake Charles, Louisiana. http://www.rssweather.com/climate/Louisiana/Lake\%20Charles/

20. Institute of Transportation Engineers, Design of Pedestrian Facilities-Recommended Practices: Providing Safety and Mobility, 2001.

21. Axelson, P. et al., Designing Sidewalks and Trails for Access, Federal Highway Administration, Washington, DC, July 1999.

22. American Association of State Highway and Transportation Officials, A Policy on Geometric Designs of Highways and Streets, 1984. 


\section{Appendix G: Stakeholder Questionnaire \\ Calcasieu Parish and the City of Lake Charles Bicycle and Pedestrian Support Public Input Session}

Personal Experience is key to having "on the ground" knowledge of bicycle and pedestrian infrastructure conditions.

Finding Out About You

*Optional*

*Name:

*Email or Phone:

City or Community of Residence:

\section{Giving Your Opinion}

Which of these improvements is most important to you? [highest (5) to lowest (1)]

Sidewalk continuity Intersection safety

Bicycle lanes Multi-use trails

Bicycle routes Suggestions?

Which of these attractors is most important to you? [highest (5) to lowest (1)]

Schools Parks

Recreation/Community facilities Post Office/Civic Buildings

Public Transit Stops Libraries

Suggestions? 


\section{Making The List}

Please take a minute to think about your experience and personal knowledge of local roads. Consider situations in which you saw someone having difficulty walking or biking along a roadway or trying to cross an intersection. Please make a list of these roadways that you believe are in need of bicycle and pedestrian improvements. We will consider these in our list of potential projects.

City or Community

Name of Road

Making The Map

Located on the table in front of you are two maps, one of Lake Charles and one of Calcasieu Parish. Please highlight along roads that you feel are in need of improved bicycle or pedestrian support (i.e. bike lanes or sidewalks). Also please mark any roads or intersections that you feel are dangerous for non-motorized travel.

Please use blue for bikes, pink for pedestrian, and red for dangerous conditions. 


\section{Telling Your Story}

If you have a personal experience you would like to share please write it below. These stories will be used as first-hand accounts of conditions, as they exist today, and will be compared with future goals.

Personal Experience:

Questions, Comments, or Concerns: 


\section{Vision, Goals, and Policies Dot Activity}

Located around the room are poster boards with titles such as "Potential Goals" and "Potential Policies." These boards have numerous examples of types of goals and policies that we could adopt. We would like to see which ones are most important to you. Please place the "dots" on the left side of the vision, goal, or policy that you like the most.

Please Use Two Dots for Each Board 